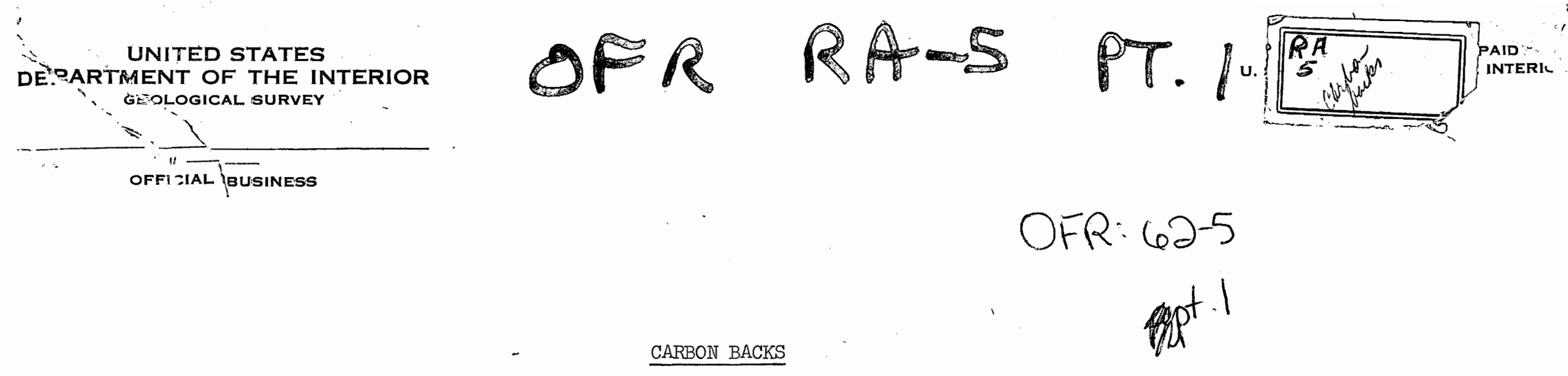

Stratigraphy and Geologic Structure of uppermost cretaceous and

Tertiary rocks of the east-central part of the San Juan

Basin, New Mexico

Dissertation - By: Elmer H. Baltz, Jr. , 


\title{
STRATIGRAPHY AND GEOLOGIC STRUCTURE \\ OF UPPERMOST CRETACEOUS AND TERTIARY ROCKS \\ OF THE EAST-CENTRAL PART OF THE SAN JUAN BASIN, NEW MEXICO
}

By

Elmer H. Baltz, Jr.

This report has not been edited for

Geological Survey format and nomenclature

\author{
A Dissertation \\ Submitted in Partial Fulfillment of the \\ Requirements for the Degree of \\ Doctor of Philosophy in Geology
}

The University of New Mẹxico

1962

en-ille report 
Abstract . . . . . . . . . . . . . . . . 1

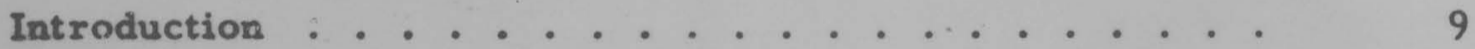

Purpose and scope . . . . . . . . . . . 9

Location and extent of area ......... . . 10

Previous work . . . . . . . . . . . . 12

Present work . . . . . . . . . . . . 13

Physiography . . . . . . . . . . . . 15

Drainage . . . . . . . . . . . 15

Land forms .............. . . . 16

General discussion . . . . . . . 16

Penistaja Cuestas . . . . . . . 18

Largo Plains . . . . . . . . 20

Tapicitos Plateau . . . . . . . . 21

Yeguas Mesas........... . 22

San Pedro Foothills ......... 24

Northe ra Hogback Belt . . . . . . 27

Cumate................. 29

V ggetation ................. 29

Stratid caphy. . . . . . . . . . . . . . 30

janeral discussion. . . . . . . . . . 30

Eretaceour socks................ 34 
Mesaverde group . . . . . . . . . 34

Definition .......... . . 34

Extent and thickness . . . . . 36

Lithology . . . . . . . . . $38^{\circ}$

Contacts . . . . . . . . 39

Age............ 40

Lewis shale.............. . . 40

Definition .......... 40

Extent and thickness ......... 41

Lithology . . . . . . . . . 4 43

Contacts . . . . . . . . . 44 44

Age . . . . . . . . . 45

Pictured Cliffs sandstone. . . . . . . . 46

Definition . . . . . . . . . 46

Extent and thickness . . . . . . 46

Lithology . . . . . . . . . 50

Contacts. . . . . . . . 55

Age............. . . 57

Fruitland formation and Kirtland shale,

undivided............. . . 57

Definition . . . . . . . . 57

Extent and thicleness. . . . . . 59

III 
Unit A . . . . . . . . . 62

Unit B . . . . . . . . 66

Unit C............ . . 75

Subsurface correlations . . . . . 77

General discussion . . . . . . . 79

Contacts . . . . . . . . . . 84

Age and correlation. . . . . . . 85

Tertiary(?) rocks. . . . . . . . . . . 88

Ojo Alamo sandstone. . . . . . . . . 88

Definition . . . . . . . . 88

Extent and thickness . . . . . . 90

Lithology . . . . . . . . . 93

Contacts............ . . 97

Age and correlation........ 101

Tertiary rocks . . . . . . . . . . 109

Nacimiento formation ........ 109

Definition ........... 109

Type locality .......... 112

Extent an 1 thĩckness . . . . . 116

Lithology . . . . . . . . 118

Contacts . . . . . . . . . 127

Age and correlation ........ 129 
San Jose formation.

Definition . ..........

Extent and thicknes s

Cuba Mesa membez

Regina member. . . . . . . . .

Llaves member. . . . . . . .

Tapicitos member. . . . . . . 163

Contacts . . . . . . . . 168

Age and correlation. . . . . . . 173

Igneous rocks . . . . . . . . . . 180

Tertiary or Quaternary deposits ........

High terrace gravel ..........

Quaternary deposits . . . . . . . . . .

Terrace gravel, colluvium, and stream-

channel gravel . . . . . . . . .

Alluvium .............. . . 184

Geologic structure................

Regional setting . . . . . . . . . . 186

Description of structure. . . . . . . . 187

Structure contour map. . . . . . . 187

Folds .............. . 188

Faults.............. 193

Joints . . . . . . . . . . 197 
Analysis of regional structure . . . . . . . . . . 198

General statement .............. 198

Nacimiento fault .............. 204

Overturrad beds............ 206

Synclinal bend .............. 212

Evidence of strike-slip movement . . . . . 217

Gallina fauit . . . . . . . . . . . . 228

San Pedro Mountain fault . . . . . . . . . 231

Archuleta anticlinorium . . . . . . . . . 237

Regional structural discontinuity . . . . . . . 248

Discussion . . . . . . . . . . . . . 254

Depositional and tectonic history. . . . . . . . . 257

Principal conclusions... . . . . . . . . . . . 261

Descriptions of stratigraphic sections of type localities. . . 264

References... . . . . . . . . . . . . . . 287 
Figure 1. Index map of parts of northwestern New Mexico

and southwestern Colorado showing the area of the present report ............

2. Geologic map of the east-central part of the

San Juan Basin, New Mexico . . . . . . In pocket

3. Correlated stratigraphic sections of Upper

Cretaceous and lower Tertiary rocks measured on the eastern side of the San Juan Basin, New Mexico. . . . . . . . . . . In pocket

4. Structure contour map of the east-central part of the San Juan Basin, New Mexico. . . In pocket

5. Diagram showing correlations of rock units as interpreted from electric logs of wells a long line $A-A^{\prime}$ (shown on Fig. 4). ...... In pocket.

6. Diagram showing correlations of rock units as interpreted from electric logs of wells and surface stratigraphic section along line B-B' (shown on Fig. 4)........ In pocket

7. Diagrans showing correlations of rock units as isterpreted from electric $\log 8$ of wells and surface stratigraphic section along line $C-C^{\prime}$ (ahown on Fig. 4) ....... In pocket 
Figure 8. Physiographic index map of the east-central

part of the San Juan Basin and adjacent

region, New Mexico ........... In pocket

9. Structural elements of the San Juan Basin . . .

10. Probable paleogeography of parts of northern

New Mexico and southern Colorado in late

Montana (Pictured Cliffs) time . . . . . .

11. Comparison of stratigraphic sections of the

typical exposures of the Nacimiento forma-

tion at the south end of Mesa de Cuba. . . .

12. Tectonic map of the northeastern side of

the San Juan Basin and the uplifts to the

east, New Mexico. . . . . . . . In pocket

13. Cross sections showing the relation of

pre-San Jose anticlines and synciines to

the synclinal bend west of the Nacimiento

and Gallina faults...........

14. Dią̀rammatic cross sections showing possible

stages of development of steeply dipping and

overturned beds adjacent to a high-angle

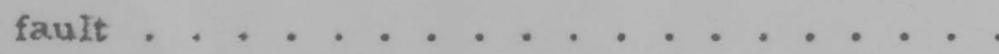

15. Lnagrammatic cross sections of several types of folds .............. 
Figure 16. Sketch and cross sections of a plastic model showing deformation resulting from right shift and tilting of a rigid plate beneath the model . . . . . . . .

17. Structural profiles and diagrams showing possible directions of shift of the San Juan Basin relative to the French Mesa-Gallina and Nacimiento uplifts . . . . . . .

18. Diagrams showing compressional and

tensional phases of subsidence of a segment of the earth's crust . . . . . . . .

19. Model showing area of horizontal tensional stress (gap) which develops during right shift on a fault having differently oriented segments . . . . . . . . . . .

20. Model showing probable configuration of Precambrian basement rocks of the northern part of the Nacimiento uplift, the French MesaGallina uplift, and the adjacent part of the San Juan Basin . . . . . . . . . . .

21. Structure contour map of the southeastern part of the Archuleta anticlinorium and adjacent parte of the San Juan and Chama basins... 
Figure 22. Structural profiles of the Horse Lake and Willow Creek anticlines. . . . . . 246

23. Diagrammatic cross sections showing hypothetical stages of development of an anticlinorium from an elongate dome ....

24. Generalized sketch model of the major features along the regional structural discontinuity . . . . . . . . .

\section{TABLE}

Page

Table 1. Age, nomenclature, and thickness of rock units in the Nacimiento uplift and eastern part of the San Juan Basin, New Mexico... . 


\section{ABSTRACT}

An area of about 1,300 square miles was mapped in parts of Rio Arriba, Sandoval, and McKinley Counties, New Mexico. The area is in the east-central part of the San Juan Basin, a large structural and drainage basin in the east-central part of the Colorado Plateau province. Six relatively distinct physiographic sectors in the area are named here: the Penistaja Cuestas; Largo Plains: Tapicitos Plateau; Yeguas Mesas; San Pedro Foothills; and Northern Hogback Belt.

The mapped area lies in the Central basin of the San Juan Basin and is bounded on the east by the Nacimiento and French MesaGallina uplifts whe re rocks ranging in age from Precambrian to Late Cretaceous crop out. Upper Cretaceous rocks crop out along the southern and eastern edges of the area, and Tertiary rocks are at the surface in most of the area.

The oldest rocks mapped are those of the Mesaverde group of Late Cretaceous age. The Mesaverde group ranges in thickness from about 1,700 feet at the southwest to about 630 feet at the northeast, and is overlain by the Lewis shale of Late Cretaceous age. The Lewis shale is about 1,900 feet thick in the northeastern part $n$ the area, but thins abruptly to about 500 feet thick in the southwestern part of the area as lower beds grade laterally into sandstone of the Mesaverde group.

The Lewis shale is overlain conformably by the Pictured Cliffs 
sandstone of Late Cretaceous age. The Pictured Cliffs, consisting of fine - to medium-grained soft sandstone with interbedded thin carbonaceous shale, is as much as 235 feet thick in the subsurface of the southwestern part of the area. It becomes thinner to the northeast and is represented by thin beds of soft sandstone and carbonaceous shale, 35-45 feet thick, that grade northeastward into the upper part of the Lewis shale.

The Pictured Cliffs sandstone is overlain by the undivided Fruitland formation and Kirtland shale of Late Cretaceous age. These rocks are about 450 feet thick in the subsurface of the western part of the area, but the thickness ranges from less than 100 feet to almost 300 feet at outcrops along the eastern side of the area. Part of the variation is the result of angular and erosional unconformity with overlying rocks, but part is the result also of local unconformities within the Fruitland and Kirtland. The sequence consists of three lithologic units. Unit A is shale and fine- to coarse-grained sandstone deposited in a ma rine and brackish-water environment. Fossiliferous marine sandstone in unit A thickens northward in the subsurface and at the surface. Unit B consists of fine- to coarse-grained sandstone and interbedded shale resting with local unconformity or unit A. The sandstone beds in unit B become finer grained westward and grade into shale. Unit C, consisting of coarse-grained sandstone and interbedded shale, rests with local unconformity on unit $B$ and is present at places in the southeastern and 
southern parts of the area. The sandstone beds of unit C thin northeastward and grade into siltstone interbedded in shale. The undivided Fruitland formation and Kirtland shale were deposited in and on the margins of an embayment of the Cretaceous sea which probably became landlocked, or nearly so, because of the rise of highlands north and east of the present San Juan Basin.

The undivided Fruitland formation and Kirtland shale are overlain unconformably by the Ojo Alamo sandstone of Tertiary(?) age. In the southern part of the area, the Ojo Alamo ranges in thickness from 60 to 100 feet but is almost 200 feet thick in the northern part. The Ojo Alamo contains a few beds of shale but consists mainly of fine-grained to very coarse grained, arkosic sandstone containing lenses of pebbles and small cobbles near the base. The Ojo Alamo was deposited by streams draining into the San Juan Basin from several sides. The principal source areas probably were the region now parts of the San Juan Mountains and the Brazos uplift. The Ojo Alamo sandstone, as mapped, seems to correlate with only the upper part of the Ojo Alamo of the type locality, and rests with erosional and slightly angular unconformity on older rocks. A microflora in the Ojo Alamo in the present area suggest Tertiary age.

The Ojo Alamo sandstone is overlain conformably by the Nacimiento formation of Paleocene age. The Nacimiento formation 
is 800 to 850 feet thick in the southern part of the area and is as much as 1,750 feet thick in the subsurface of the northern part. At outcrops along the eastern edge of the area, the thickness is varied from less than 500 feet to almost 1,400 feet because of folding and erosion prior to deposition of overlying rocks. In the southern part of the area the Nacimiento consists mainly of clay shale with some interbedded soft sandstone and a few resistant sandstone beds. To the north the Nacimiento contains a greater proportion (locally more than 50 percent) of sandstone. The northern facies is part of a huge fan of volcanic and orogenic debris eroded from highlands on the north and northeast and spread to the southwe st into the San Juan Basin. The southern facies is composed partly of finer grained material deposited at the distal edges of the fan, but consists also of reworked Cretaceous sediments eroded from uplifted areas south and west of the basin. In the southern part of the area, the Nacimiento formation is of early and rniddle Paleocene age, but farther north rocks of late Paleocene age probably are present also.

The Nacimiento formation is overlain with erosional and angular unconformity by the San Jose formation of Eocene age. The San Jose is the surface formation in most of the region, and its preserved parts $x$ ange in thicloness from about 200 to 1,430 feet in ze southern part of the area to as much as $1,700-1,800$ feet in the 
northern part. Four mappable lithologic units of the San Jose are here named: the Cuba Mesa member; Regina member; Llaves member; and Tapicitos member. The Cuba Mesa member at the base of the formation consists mainly of conglomeratic arkosic sandstone $220-350$ feet thick at most places, but is 782 feet thick at the type locality. North, south, and west of the type locality the upper part of the Cuba Mesa member tongues out into the Regina member. The Regina member, resting on the Cuba Mesa member, consists of variegated shale, sandy shale, and some sandstone. The member ranges in thickress from about 600 feet in the southeastern part of the area to about 1,640 feet in the east-central part of the area, and about 575 feet at the type locality in the northeastern part of the area. The variations ir thickness are attributable in part to intertonguing relations between the Regina member and the Cuba Mesa and Llaves members, and in part to intra-member thickening. In the northeastern part of the area, most of the San Jose formation is composed of thick beds of conglomeratic arkosic sandstone of the Llaves member which is about 1,300 feet thick in its type area. The lower part of the Llaves member grades out southward into the Regina member, but a persistent medial sandstone unit of the Llaves rests on the Regina in much of the north-central part of the area. The upper part of the Llaves member, above the persistent medial sandstone. wedges out southwestward and westward into the Tapicitos member which 
consists of red shale and sandy shale with some lenticular resistant coarse-grained sandstone. The thickest preserved part of the Tapicitos member is about 500 feet thick. The arkosic conglomerates of the Cuba Mesa and Llaves members probably were derived mainly from Precambrian terranes north and northeast of the present basin. Much of the Regina member was derived from Cretaceous rocks eroded from the rising Nacimiento uplift. The redbeds of the upper part of the Regina member and the Tapicitos member are probably second-cycle sediments derived from Permian and Triassic red beds. At places along the Nacimiento uplift beds assigned to the Regina member overlap the Cuba Mesa member and older rocks including the Lewis shale, indicating folding in this zrea during deposition of part of the Regina. The Central basin probably was filled by sediments of the San Jose formation during Eocene or Oligocerie time, and the se rocks may have lapped out of the basin onto the worn-down source areas.

Dikes of mafic igneous rocks of Miocene(?) age fill fractures in the San Jose formation in the north-central part of the area. These northerly trending dikes are related to the large swarm of dikes farther north in the San Juan Barin.

Terrace gravel deposits occur in the San Pedro Foothills adjacent. to the Nacimiento uplift. The topographically highest remnants of gravel may be of Pliocene age and may correlate with the Bridgetimber gravel of the northwestern part of the San Juan Basin. Deposits of gravel at 
lower altitudes are of Quaternary age and cap terraces and occur in the valleys of some of the present streams. Recent alluvium occurs in all the larger valleys of the area.

The northwest-trending axis of the San Juan Basin extends diagonally across the north-central part of the area. Rocka in the southwestern and western parts of the area dip gently northeastward toward the axis. In the southeastern part of the area there is a series of northwesierly-plunging asymmetrical anticlinal noses which were formed during several stages of folding in Cretaceous and early Tertiary time. The southeastern parts of the noses have been rotated and tilted westward in the belt of sharp folding and local overturning along a synclinal bend west of the Nacimiento fault at the western side of the Nacimiento uplift. Surface stratigraphic information and well data indicate the presence of similar subsurface folds farther north on the eastern side of the area. North of the Nacimiento uplift, the rocks of the eastern part of the area dip steeply westward on a curved, westfacing monocline which forms the western flank of the French Mesa-Gallina uplift. There are a few small faults in the area, but the displacements on most of them are 200 feet or less.

The stratigraphy and structure of the mapped area provide evidence concerning the nature of Laramide deformation of the eastern and northeastern parts of the San Juan Basin and adjacent uplifts. The Nacimiento and Gallina faults on the eastern margin of the basin are probably 
high-angle reverse faults. Right shift along the se faults indicates that the basin was downbuckled and shortened relative to the Nacimiento and French Mesa-Gallina uplifts because of a deep-seated northeasterly oriented Laramide compressional force. The San Pedro Mountain fault near the northern end of the Nacimiento uplift was produced by local horizontal tension near the junction of the northerly trending Nacimiento fault and the northeasterly trending Gallina fault.

The northwesterly trending Archuleta anticlinorium along the northeastern margin of the San Juan Basin probably originated as an intrabasinal arch in a large Late Cretaceous structural and sedimentary basin. Analysis of the Horse Lake and Willow Creek anticlines suggests that the southeastern part of the anticlinorium originated as a broad elongate dome that was upwarped and deformed into an anticlinorium by the northeasterly oriented Laramide compressional force. The Nacimiento and Gallina faults ard the southeastern margin of the anticlinorium mark a regional structural discontinuity alorg which crustal blocks with differing orientations and competence yielded differently to the regional compressional force. 


\section{INT RODUCTION}

\section{Purpose and Scope}

The San Juan Basin, a large intermontane structural basin in the eastern part of the Colorado Plateau physiographic province, has a thick sequence of Cretaceous and early Tertiary rocks which crop out in a large region of northwestern New Mexico and southwestern Colorado. The Cretaceous rocks have been studied in considerable detail in many parts of the basin because these rocks contain large deposits of coal, oil, and natural gas. The Tertiazy rocks contain classic vertebrate faunas of Paleocene and early Eocene age, but because the se rocks do not contain economically important deposits of hydrocarbons and minerals they have been of little interest to most geologists. However, the stratigraphic relations and facies distribution of latest Cretaceous and early Tertiary rocks reflect not only the Laramide structural and depositional history of the San Juan Basin, but also the Laramide structural history of uplifts bounding the basin.

The present study of an area of approximately 1, 300 square miles in the east-central part of the San Juan Basin was done by the writer as part of a ground-water investigation of the scuthern part of the Jicarilla Apache Indian Reservation by the U.S, Geological Survey. It was determined that rocks older than latest Cretaceous age are buried too deeply to be considered as possible sources of ground water. Howeve:. 
latest Cretaceous and early Tertiary rocks consist of several stratigraphic units which contain potential aquifers. Accordingly, the area of study was planned to include not only the southern part of the reservation, but also the region south and east of the reservation where potential aquifers crop out. The results of the ground-water investigations are the subject of another report. The present report presents only the geologic data and geological conclusions drawn therefrom.

The study of the eastern side of the San Juan Basin was augmented by detailed work in other parts of the basin, and by reconnaissance examination of rocks in the region surrounding the basin. The detailed and reconnaissance examinations outside the present area we re made by the writer during the course of other work for the U. S. Geological Survey during parts of the period 1951-1960.

\section{Location and Extent of Area}

The area investigated for the present report (Figs. 1 and 2) includes approximately 1,300 square miles in parts of Rio Arriba, Sandoval, and McKinley Counties, northwestern New Mexico. The eastern boundary is the foothills and lower slopes of Sierra Nacimiento and San Pedro Mountain in Sandoval County, and the west edge of the irregular belt of lower mountains and mesas north of San Pedro Mountain in Rio Arriba County. The northern, western, and southern boundaries were chosen arbitrarily as the township lines which include all the 


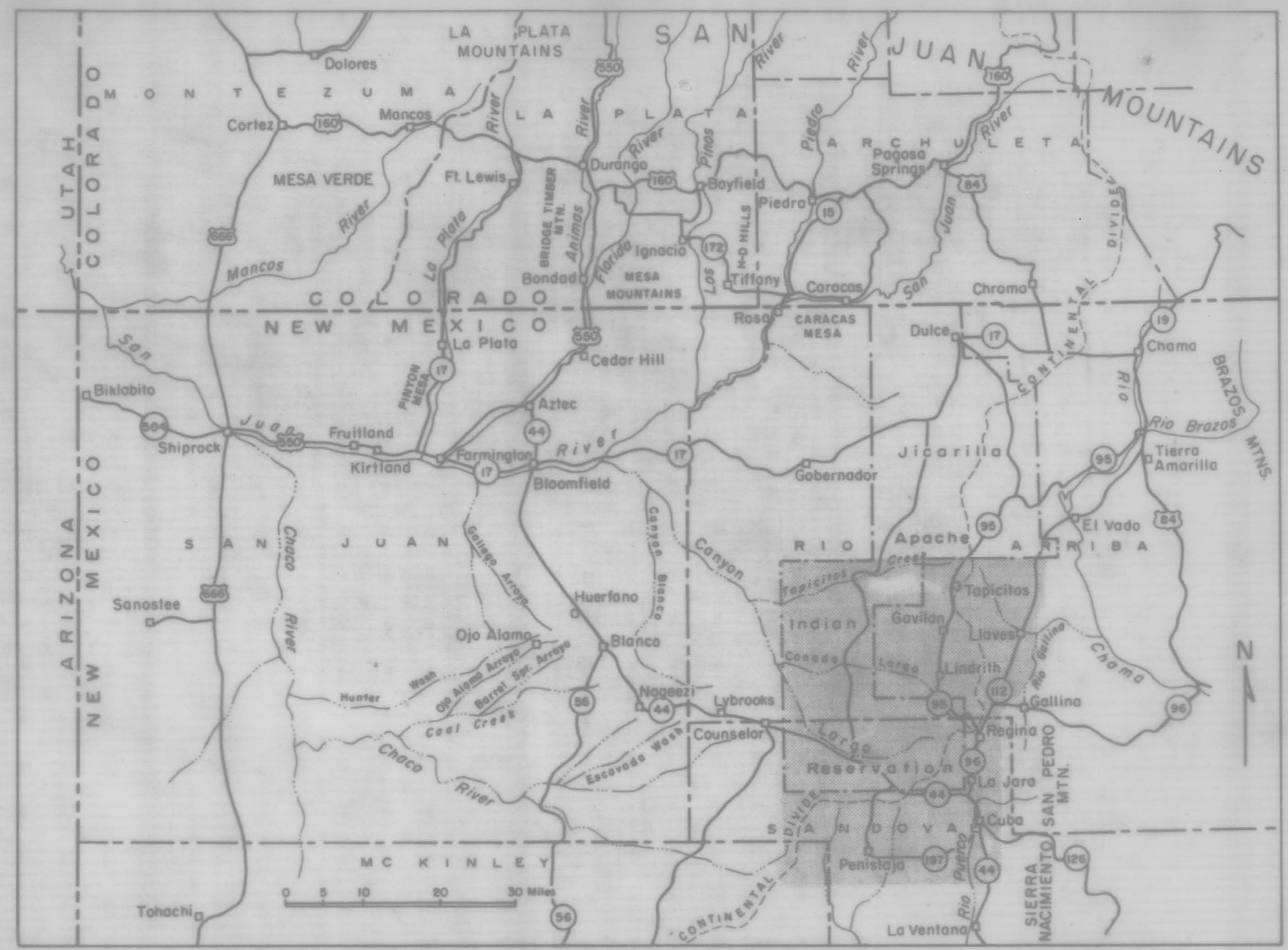

Figure 1. - - Index map of parts of northwestern New Mexico and southwestern Colorado showing the areo of the present report (stippled). 
southern part of the Jicarilla Apache Indian Reservation and the area

to the south where potential aquifers crop out. Most of the area

investigated lies within T. 20 N. to T. 26 N., R. I W. to R. 5 W. The northeastern part of the area is in parts of T. 24 N. to 26 N., R. 1 E.

The area extends from about latitude $35^{\circ} 55^{\prime}$ to about latitude

$36^{\circ} 31^{\prime}$. The northeastern edge of the area is at about longitude $106^{\circ} 45^{\prime}$, and the western edge is at about lo igitude $107^{\circ} 10^{\prime}$.

\section{Previous Work}

The geology of parts of the area of this report has been mapped. and described briefly in several earlier reports. The southern and eastern parts of the area were part of a much larger region mapped in reconnaissance by Gardrer (1909) who also briefly described stratigraphic relations of Cretaceous and Tertiary rocks in this area (Gardner, 1910). Renick (1931) mapped the rocks along the western side of Sierra Nacimiento and San Pedro Mountain, studied the stratigraphy and structure of these rocks, and discussed ground-water conditions in the eastcentral and southeastern part of the area of the present report. Dane (1932) published a brief description of latest Cretaceous and Paleocene rocks of the region, and (Dare, 1936) briefly examined and described rocks in the southern two tiers of townships (T. 20-21 N., R. 1-5 W.) -of the area of the present report, and mapped them during a study of the La Ventana-Chacra Mesa coal field which lies south and southwest of the area of the present report. 
Dane (1946) also published a chart and description of the stratigraphy of latest Cretaceous and Tertiary rocks of the eastern side of the San Juan Basin. This included a description of the rocks in parts of a narrow belt in the eastern part of the area of the present report. Wood and Northrop (1946) mapped the Nacimiento Mountains (Sierra Nacimiento) and San Pedro Mountain, and the foothills to the west which were previously mapped by Renick (1931). The Dul ce-Chama area mapped by Dane (1948) includes, at its southern end, the northeastermost two townships (T. 26 N., R. 1 E., and R. 1 W.) of the area of the present report. A narrow strip on the eastern edge of the present area from the northern part of T. $22 \mathrm{~N} ., \mathrm{R} .1 \mathrm{~W}$. to the northeast corner of the area was mapped as parts of three master's theses of the University of New Mexico by Hutson (1958), Fitter (1958), and Lookingbill (1953).

The southern part of the Jicarilla Apache Indian Reservation and much of the area to the east have not been mapped previously, and lithologic units of less than formational rank in Tertiary rocks have not been mapped previously in this region.

\section{Present Work}

Fieid work for the present report was done from May to October, 1959, and in May, 1960. Subsequent field work was done during brief periods in 1960 and the early part of 1961 . The writer was assisted by S. R. Ash during the mapping and measuring of stratigraphic sections 
in 1959 and in May, 1960, and this assistance is gratefully acknowledged. he geology of the eastern one-third of the area was mapped in considerable detail in order to determine stratigraphic relations of the rock units. The relations determined provided the basis for differentiation of rock units in the larger part of the area to the west, and this part of the area was mapped rapidly because of the relatively simple stratigraphy, good exposures, and ease of access of many roads constructed for oil and gas exploration. All geologic mapping was done aerial photographs.

A planimetric base map was compiled by the writer at the scale of $1: 63,360$ ( 1 inch equals 1 mile). The eastern part of the base map was compiled from parts of the La Ventana, Cuba, Liaves, and Horse Lake 15-minute quadrangle topographic maps of the U. S. Geological Survey. The part of the map west of longitude $107^{\circ} 00^{\prime}$ was compiled from the 30-minute quadrangle planimetric maps of the New Mexico State Highway Commission Flanning Survey. Geology mapped in the field on aerial photographs was plotted on the available topographic maps, and then transferred to the planimetric base. For the part of the area for which to pographic maps were not available, the geology was transferred directly from the aerial photographs to the planimetric base by means of the Sairman ovexhead projector (Geologic map, Fig. 2).

A study of the subsurface geology of the area was done by means of electric logs of wells drilled for oil and gas, and surface stratigraphic 
sections measured in the field. Correlated surface stratigraphic sections are shown on Figure 3. A structure contour map (Fig. 4) and stratigraphic correlation diagrams (Figs. 5, 6, and 7) were prepared to illustrate the subsurface geology.

\section{Physiography}

Drainage

Most of the western two-thirds of the area investigated is drained by intermittent streams which flow westward and are tributary to Canyon Largo. The intermittent stream in Canyon Largo flows to the northwest out of the area, and discharges into the San Juan River. The Continental Divide trends generally north and south across the northeastern part of the area but is very sinuous in places. Near Regina the divide bends toward the southwest. In the southern part of the area the divide is an east-west line of hills and mesas, but in the southwestern part of the area, it is alined in a north-south direction.

The region east of the Continental Divide is in the Rio Grande watershed. Intermittent streams east of the divide ịn Rio Arriba County drain into the Rio Gallina which flows intermittently to the northeast from San Pedro Mountain. Outside the area, the Rio Gallina flows into the Rio Chama, a majox tributary of the Rio Grande. The extreme northeastern part of the area is drained by Archuleta Arroyo which drains into the Rio Chama. 
The western side of San Pedro Mountain in Sandoval County is drained by streams flowing intermittently westward to San Jose Creek. La Jara Creek and Riro de los Pinos both are perennial streams in their upper courses, but become intermittent before reaching San Jose Creek. San Jose Creek, which is intermittent for most of its length, extends southward between San Pedro Mountain and the Continental Divide to the vicinity of Cuba where it joins the Rio Puerco.

The Rio Puerco flows southward and is the master stream for drainage of the southern part of the area. Encino Wash and Arroyo San Ysidro drain southward and, outside the area, jein Torreon Arroyo, a southeastward-flowing intermittent tributary of the Rio Puerco. Several small westward-flowing streams such as Rito Leche, Nacimiento Creek, and Senorito Creek (in Senorito Canyon) have perennial streams of water in their upper courses on Sierra Nacimiento, but their flow becomes intermittent before reaching the Rio Puerco. In this region even the Puerco flow pennially only in its upper course north of Cuba. The Rio Puerco joire the Rio Grande almost 120 miles south of Cuba.

\section{Land Torm:}

General Diecuesion

Neariy all the San Juan Basin lies within the Navajo section of th- Cclorado Plateau phyaiographic province (Fenneman and Johnson, 1946). a gion of young plateaus with moderate to strong relief. 
The predominant feature of erosion is the stripping of nearly horizontal sedimentary beds to leave outlying mesas and buttes. Locally the major streams have incised themselves into sofi Cretaceous and Tertiary rocks and formed fairly deep, steep-walled canyons. The resulting land forms are dependent directly on the geologic structure and the lithologic character of Cretaceous and Tertiary rocks. These rocks consist of units of thick shale and interbedded thick to thin sandstone.

The sandstone units are more resistant to erosion than the shale units, and where the strata are nearly horizontal, sandstone forms mesas and broad benches. The easily-eroded shale units form valleys and steep slopes between the sandstone units. Some of the thick shale units contain numerous beds of lenticular, thin, soft sandstone and sandy shale which are only slightly more resistant to exosion than the enclosing shale beds. In places the differential erosion of rocks of this type has given rise to intricately dissected badlands.

Where the strata are tilted steeply and eroded deeply, the resistant sandstone units form "hogback" ridges between broad valleys cut in the intervening shale and gives rise to belts of nearly parallel ridges and valleys.

The granite which forms much of San Pedro Mountain and Sierra Nacimiento on the eastern edge of the area is more resistant to erosion than the sedimentary rocks preserved in the San Juan Basin. The steepIy tilted sedimentary rocks preserved on the western side of the mountainous region must have been mainly continuous across that region 
before uplifting and erosion occurred. San Pedro Mountain and the Sierra Nacimiento are considered to be an extension of the Southern Rocky Mountains (Fenneman and Johnson, 1946); thus their western edge marks the eastern boundary of the Colorado Plateau physiographic province in this region. North of San Pedro Mountain the high mesas and plateaus lying east of the area of the present report are considered to be part of the Colorado Plateau. The eastern boundary of the physiographic province in this latitude is the Brazos Mountains which lie nearly 40 miles northeast of the area of this report.

There are six relatively distinct physiographic sectors in the mapped area. These are here named: Penistaja Cuestas; Largo Plains; Tapicitos Plateau; Yeguas Mesas; San Pedro Foothills; and Northern Hogback Belt (Fig. 8).

Penistaja Cuestas

The land surface of the southern part of the area is characterized by several major, sloping topographic benches which extend from east to west across the area in broad curved bands interrupted only by the narrow valleys of southward-draining arroyos. This sector is here named the Penistaja Cuestas. Each of the major sloping topographic benches or cuestas is held up by a thick unit of sandstone, and has a steep escarpment for its southern margin. Because the cuestas are incised deeply by canyons at places, their southern edges are sinuous, but in general the erosional escarpments face to the south, southwest, or southeast. 
Soft, shaly rocks overlying the sandstone units have been stripped back to the north, in places for several miles, so that the tops of the cuestas are essentially dip-slopes cut on the upper surface of each sandstone unit. The slope of the cuestas is to the north, or a component of that direction, and reflects the regional structural dip of the rocks.

Each topographic bench or cuesta is separated from the next bench to the north by an intervening band of valleys and low rounded hills cut in units composed mainly of shale. Thin resistant beds in the shale units hold up hills and minor benches. Near the northern edge of each belt of valleys and low hills the land surface rises abruptly and culminates in the steep erosional escarpment forming the southern edge of the next sandstone-capped cuesta succeeding to the north. Streams crossing the shale units have broad alluviated valleys, but where the streams cross the bench-forming sandstone units they have narrow valleys, or they are in deep canyons. The drainage of the sector is to the south.

The southern boundary of the Penistaja Cuestas sector lies south of the area of this report and the sector is continuous west of the area. The northern boundary is defined as the Continental Divide from Regina southwestward to the northwestern part of T. 21 N., R. 4 W. From there the boundary extends northwestward to the upper part of Venado Canyon in $\mathbf{T}, 32 \mathrm{~N}, \mathrm{R}, 5 \mathrm{~W}$. This boundary includes within the Penistaja Cuestas the area of moderately strong topographic relief and tilted rocks 
which are near the southern edge of the Central basin structural segment of the San Juan Basin (Kelley, 1950). Along most of the northe rn boundary of the Penistaja Cuestas the land surface slopes steeply northward from a series of rugged mesas and cuestas to a region of nearly horizontal rocks and low topographic relief which is the Largo Plains. At the east the Penistaja Cuestas me rge with the San Pedro Foothills, and with the steeply-tilted rocks at the foot of Sierra Nacimiento.

Altitudes of the Penistaja Cuestas sector become higher from south to north. The altitude of the southermost cuestas ranges from. a little less than 6,600 feet in the extreme southwestern corner of the area, to a little more than 7,300 feet in the southeastern corner. The highest altitudes are along the Continental Divide, and range from 7,450 feet in the southwestern part of T. 22 N., R. 5 W., to about 7,700 feet in the southwestern part of T. 22 N., R. 2 W.

\section{Largo Plains}

Canyon Largo in the western part of the area is bordered on the northeast and on the southwest by broad plains which slope gently toward the intermittent stream. These plains, here named the Largo Plains, have been dissected mildly by the intermittent streams tributary to Canyon Largo so that the region is one of broad low mesas separated by intervening swales and shallow valleys. In the west-central part of the area Canyon Largo is an entrenched stream flowing in a steep-walled 
canyon whose bottom is almost 200 feet below the plains. Similarly, in the northwestern part of the area the lower courses of Tapicitos Creek and smaller tributaries of Canyon Largo are steep-walled canyons incised deeply in the plains.

The plains bordering Canyon Largo were formerly part of a broad valley which trended northwestward and was graded to the San Juan River at a lime when that river had not carved the deep canyon through which it now flows. The ancient valley of the Largo was as much as 10 miles wide in places, and had a gradient of about 7 feet per mile to the northwest in the Jicarilla Apache Indian Reservation.

Altitudes along Canyon Largo range from about 6,600 feet near Otero Ranch to more than 7,000 feet in the southwestern part of T. 22 N., R. 3 W. Southwest of Canyon Largo the plains rise gently to altitudes of about 7,000 feet. Above the southwestern edge of the old valley rise the high cuestas and mesas of the Penistaja sector. Northeast of Canyon Largo the plains slope gently up to altitudes of 6,800 to 7,000 feet. At the northeastern edge of the old valley the intricately dissected mesas of the Tapicitos Plateau rise abruptly.

\section{Tapicitos Plateau}

Most of the northern and central part of the area is a high plateau which has been dissected greatly by the westward-flowing intermittent streams tributary to Canyon Largo. This dissection has caused the remnants of the plateau to stand as broad,irregular, sandstone-capped 
mesas extending westward from the Continental Divide to the Largo Plains. The plateau is triangular, becoming narrower to the south until it merges, around the eastern end of the Largo Plains, with the Penistaja Cuestas sector along the Continental Divide in T. 22 N., R. 2 W., and R. 3 W. The dissected plateau is here called the Tapicitos Plateau for Tapicitos Creek which heads in the eastern part of the upland.

The western boundary of the plateau is the sinuous, steep, irregular, erosional escarpment overlooking the Largo Plains. The eastern edge may be defined conveniently as the Continental Divide northward from the northeastern part of T. $21 \mathrm{~N} ., \mathrm{R}, 4 \mathrm{~W}$. In a sense, the high mesas and cuestas along the divide west of T. 21 N., R. 4 W. are erosional remnants of the Tapicitos Plateau, but they are more conveniently grouped with the Penistaja Cuestas sector. The Tapicitos Plateau extends far to the north of the present area of investigation.

Altitudes on the Tapicitos Plateau range from about 6,800 feet on the lower slopes, to a little more than 7,600 feet at the tops of the highest mesas. Throughout the area there are nume rous mesas whose tops are at altitudes between 7,400 and 7,500 feet. This seems to indicate that a wide-spread erosional surface of relatively low relief characterized the plateau before the canyon-cutting e rosional cycle during which the plateau was dissected and the Largo Plains were formed.

\section{Yeguas Mesas}

Near the northeastern corner of the area numerous high mesas 
rise about 500 feet above the general level of the Tapicitos Plateau. The mesas are long and narrow, and are separated by deep, steepwalled canyons cut in thick sandstone beds by the intermittent streams of Canyoncito de las Yeguas and its tributaries. Topographic relief from tops of mesas to bottoms of adjacent canyons is as much as 1,000 feet in about one-half mile at some places. This area of high mesas and deep canyons is here named the Yeguas Mesas sector.

Altitudes in Canyoncito de las Yeguas range from about 7,000 feet in the eastern part, to a little more than 7,500 feet in the we st. The highest mesas are along the eastern side of the sector where altitudes are as much as 8,500 feet. The altitude of the tops of the highest western mesas along the Continental Divide is nearly 8, 000 feet.

The tops of many of the Yeguas mesas appear to be remnants of a high-level erosion surface which sloped westward. This surface may have been widespread forme rly, inasmuch as extensive areas having similar altitudes occur in the region east of the area of this report, and isolated mesas whose tops are at altitudes of $7,700-8,000$ feet occur along the Continental Divide on the Tapicitos Plateau in the eastern part of the area. A few isolated buttes and mall mesas rising above the Tapicitos Plateau may be erosional remnants of the higher Yeguas Mesas surface which was mainly destroyed by the erosional cycle that produced the lower Tapicito Plateau eurface. 
San Pedro Foothills

The foothills of San Pedro Mountain from the upper drajnage of San Jose Creek to the upper drainage of the Rio Puerco are characterized by westward-sloping terraces which extend from San Pedro Mountain to San Jose Creek. The terraces are separated by westward-trending valleys which are mainly broad and shallow at the west, but are narrow and deep at the east. This area is here called the San Pedro Foothills sector. Deposits of gravel composed mainly of granite derived from San Pedro Mountain cap terraces at several different levels, and occur also in the upper valleys of the major streams. In deep canyons cut below the levels of the terraces near the foot of San Pedro Mountain, Cretaceous and Tertiary sedimentary rocks are exposed standing nearly vertical. These rocks are bevelled by the westward-sloping terraces, and their structure and lithology have only minor influence on the land forms.

Altitudes at the western side of the foothills belt range from a little more than 7,000 feet in the valley of San Jose Creek south of La Jara, to almost 7,600 feet at the head of the valley north of Regina. Altitudes at the top of some of the terrace-gravel deposits at the foot of San Pedro Mountain are a little more than 8,400 feet.

Bryan and McCann (1936) briefly examined the San Pedro Foothills region as part of a study of the physiography of the upper Rio Puerco, and postulated that the terraces are remnants of two pediments which were 
cut to the grades of two older and higher temporary erosional levels of San Jose Creek and the Rio Puerco. The higher and older of these postulated pediments was called the La Jara pediment (Bryan and McCann, 1936, p. 160-164). According to Bryan and McCann the La Jara pediment extended as a sloping surface from the foot of San Pedro Mountain to San Jose Creek, and was supposed to have been overlain by an almost continuous veneer of gravel. The postulated lower and younger erosion surface, called the Rito Leche pediment (idem, p. 164), was said to have been a broad surface between the Nacimiento Mountains and the Rio Puerco south of Cuba. In the San Pedro Foothills, the Rito Leche pediment was said to be represented by the low terraces or benches along the edges of the San Jose Creek and its tributaries. These terraces are higher than the floor of the present valley, but are lower than the postulated La Jara pediment.

A more detailed study of the area by the present writer indicates that the physiographic history of the San Pedro Foothills sector is more complex than envisioned by Bryan and McCann, and that the concept of the La Jara pediment is incorrect. The gravel deposits are not as extensive as indicated by Bryan and McCann (see Fig. 2), and they are on several distinctly different, westward-sloping surfaces, rather than being on one geperal surface as required by the concept of the La Jara pediraent.

The highest gravels ( $\mathrm{QTg}$ on Fig. 2) are on remnants of what 
may have been a pediment surface. This surface slopes away from San Pedro Mountain at altitudes ranging from about $8,000-8,400$ feet and may be equivalent to the highest erosional surface in the Yeguas Mesas. Other mesas whose tops are at altitudes of $7,700-8,000$ feet occur at places along the Continental Divide west of San Pedro Mountain, and the tops of these mesas also may be remnants of the erosional surface capped by the highest gravel deposits on the flanks of San Pedro Mountain.

Most of the lower-level gravel deposits are much longer than they are wide, and they extend westward from deep canyons cut in Precambrian rocks on the west side of San Pedro Mountain. At places the gravel deposits are thickest in their central parts and thinner at their edges. From these observations it seems probable that most of the lower-level gravel was deposited in stream channels cut in soft Cretaceous and Tertiary rocks during earlier stages of erosion of the foothills belt. During later stages of erosion the gravels protected the immediately underlying soft rocks from erosion; thus the former stream channels are now gravel-capped terraces. The old interstream areas, held up by soft rocks not protected by gravel, were more susceptible to erosion and were worn away, perhaps by lateral migration of the streams to the edges of their gravelly channels where they were able to cut into the soft Tertiary rocks to form the present valleys. Comparison of gradients and altitudes of some of the gravel-capped terraces indicates that the streams which deposited the gravel were captured only recently 
by San Jose Creek. Prior to this some of the streams probably drained westward, and the Continental Divide was at the crest of Sierra Nacimiento and San Pedro Mountain. The westward-flowing upper course of San Jose Creek east of Regina seems to have been the last tributary to be captured. It probably flowed, formerly, to the west through the gap in the Continental Divide (traversed by State Highway 95) west of Regina, and into the upper part of Canada Larga. The altitude of the gravelcapped terrace along upper San Jose Creek east of Regina is about 7,500 feet. The altitude of the gap in the Continental Divide west of Regina is a little less than 7,500 feet.

Northern Hogback Belt

Extending northward from the San Pedro Foothills, along the northeastern edge of the area of investigation, is a belt characterized by long, narrow sandstone ridges separated by alluvial valleys which are mainly parallel to the ridges. The sandstone ridges, known as "hogbacks", are breached by gaps through which the intermittent streams of the belt drain eastward to Rio Gallina. This hogback belt is geologically a continuation of the San Pedro Foothills, but the hogback belt has been more deeply eroded, and consequently has different land forms. Differential resistance to erosion of the steeply tilted sedimentary rocks has caused valleys to be cut in the shale units, leaving the more resistant sandstore beds as nearly parallel ribs or hogback ridges rising above the intervening valleys. The name "Northern Hogback Belt" is applied to this 
sector to distinguish it from the hogback belt parallel to the front of Sierra Nacimiento south of the area investigated.

The major topographic feature of the Northern Hogback Belt is the high sandstone ridge in the eastern part of the belt. Although this hogback is cut at places by transverse gaps, it forms a nearly continuous ridge from the upper tributaries of San Jose Creek northward beyond the northern part of the area. The altitude of the top of this hogback is, at places, more than 7,800 feet. The narrow ridge rises $400-600$ feet above the flanking valleys. Sandstone beds of stratigraphically higher formations hold up ridges west of the main hogback, but these sandstones are less resistant to erosion and the hogbacks to the west are, for the most part, topographically lower than the eastern hogback. Also, the north-south continuity of the western hogbacks is interrupted by broad, transverse alluviated valleys and low terraces. In most of the hogback belt west of the main hogback altitudes range from a little less than 6,900 feet to about 7,400 feet. The large hogback (or steeply sloping cuesta) in the western part of T. 26 N., R. 1 E. attains the highest altitude--8, 447 feet--of the Northern Hogback Belt.

The upper valleys of Arroyo Blanco and Almagre Arroyo are cut in soft, gently dipping Tertiary rocks and do not have the characteristic landforms of the Northern Hogback Belt. However, these valleys are at lower altitudes than the Tapicitos Plateau west of the Continental Divide, and they are drained to the east. For these reasons they are included 
in the Northern Hogback Belt.

\section{Climate}

The recorded average annual precipitation in the area ranges from 16.71 inches at Gavilan to 11.91 inches at Otero Ranch (New Mexico State Engineer, 1956, p. 277-280, 294). The average precipitation is least in June and greatest in July and August. In general, the wettest part of the area is the eastern side, with the topographically higher parts receiving more precipitation than the lower parts. The amount of precipitation becomes less to the west, and the southwestern corner of the area is the driest part.

According to published records of the New Mexico State Engineer (1956) the average frost-free season is 77 days (June 25 to Sept. 10) at Gavilan (alt. 7,350 ft.).

\section{Vegetation}

The vegetation of the area varies with altitude and precipitation. The lower valleys and plains support sparse grass and, locally, thick growths of sage brush. Near springs, and in some of the valleys where ground water is at shallow depth, cottonwoods occur. On the slopes and lower ridges and hills, particularly in sandy soil, juniper and pinon pine are the common trees. The juniper-pinon zone merges upward into stands of ponderosa pine which occur on the sandstone-capped cuestas of the Penistaja sector, the mesas of the Tapicitos Plateau 
and Yeguas Mesas, the sandstone ridges of the Northern Hogback Belt, and the gravel-capped terraces of the San Pedro Foothills. Scrub oak is common in the upper part of the juniper-pinon zone, and with the ponderosa pines. Ponderosa pines clothe the slopes of the Sierra Nacimiento and San Pedro, and merge upward into stands of spruce and fir which are on the higher parts of the mountains and on northfacing canyon walls. Groves of aspen are common in the moister parts of the mountains.

\section{STRATIGRAPHY}

\section{General Discussion}

Rocks ranging in age from Precambrian to Recent are exposed in the Nacimiento uplift and the eastern part of the San Juan Basin. The nomenclature, age, and thickness of these rocks are summarized in Table 1. Shown on Figure 9 are the structural elements of the San Juan Basin and adjacent regions that are mentioned in discussing the stratigraphic units.

The oldest rocks of the region are igneous and metamorphic rocks of Precambrian age that form a basement on which younger sedimentary rocks rest. The Precambrian rocks form the bulk of San Pedro Mountain and Sierra Nacimiento, and have been encountered at depths of 13;000 feet or more in wells drilled in the eastern part of the San Juan Basin. Precambrian rocks exposed in the Nacimiento 
Table 1.--Age, nomenclature, and thickness of rock units in the Nacimiento uplift and eastern part of the San Juan Basin, New Mexico. (Compiled partly from Renick, 1931; Dane, 1936; Wood and Northrop, 1946.)

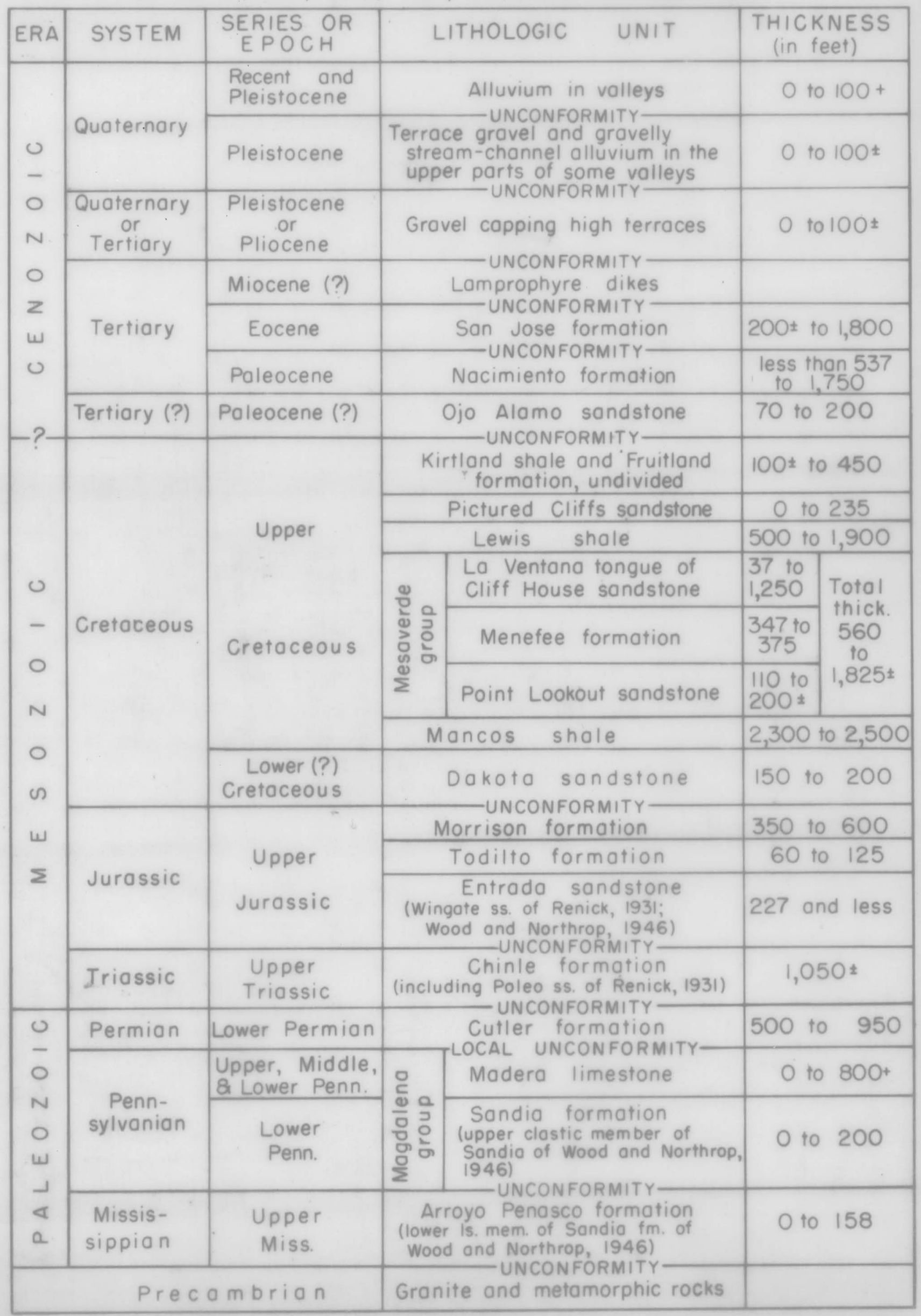




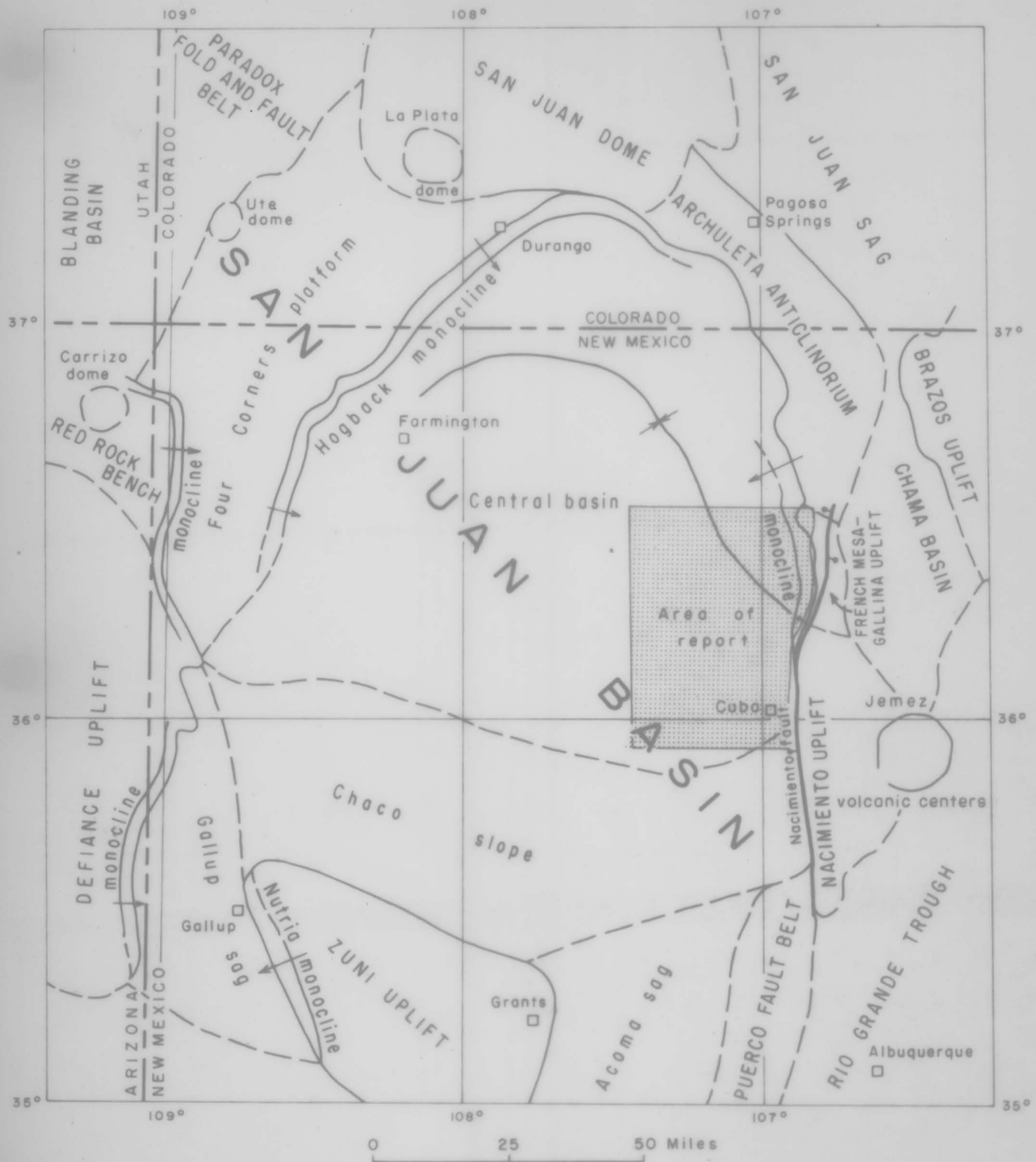

Figure 9.--Structural elements of the San Juan Bosin. Modified from Kelley (1951, p.125) and Kelley and Clinton (1960, fig.2). 
uplift were described by Renick (1931, p. 12-13) as being mainly coarsegrained granite with some dikes of fine-to coarse-grained basic igneous rock and quartz veins. There are a few outcrops of mica schist into which the granite probably was intruded.

Paleozoic rocks lie on the Precambrian basement and consist of thick beds of limestone, shale, sandstone, and conglome rate of Mississippian, Pennsylvanian, and Permian age. These rocks are present at places in the higher parts of Sierra Nacimiento and San Pedro Mountain, and crop out also on the lower slopes of the mountains (Renick, 1931, p. 13-24; Wood and Northrop, 1946; Armstrong, 1955, p. 6-17; Fitzsimmons, Armstrong, and Gordon, 1956, p. 1936-1940). Paleozoic rocks are present also in the subsurface of the San Juan Basin.

The Paleozoic rocks are overlain by a thick sequence of Mesozoic rocks consisting of sandstone and shale of Triassic, Jurassic, and Cretaceous age. Triassic rocks are present in a structural sag between San Pedro Mountain and Sierra Nacimiento, and crop out also in the belt of steeply dipping rocks at the western edge of the mountains. Jurassic rocks also crop out in this belt along the edge of the mountains. Cretaceous rocks consisting of thick units of sandstone and shale crop out in the belt of steeply dipping rocks, and are the surface rocks in much of the San Juan Basin outside of the Central basin. The Mesozoic rocks are present also in the subsurface of the Central basin. 
Cenozoic rocks consisting of thick units of sandstone and shale of early Tertiary (Paleocene and Eocene) age are the surface rocks in most of the Central basin.

The rocks of latest Cretaceous and early Tertiary age, with which the present report is concerned primarily, are restricted in occurrence to the Central basin. Rocks older than latest Cretaceous age are at depths of more than 3,000 feet in the southern part of the Jicarilla Apache Reservation. The oldest rocks mapped in the present investigation are those of the Mesaverde group of Late Cretaceous age. Rocks older than this are shown on the geologic map (Fig. 2) as Cretaceous and older rocks, undivided $(\mathrm{Ko})$. These rocks, ranging in age from Precambrian to Late Cretaceous as shown in Table 2, were mapped by Renick (1931) and by Wood and Northrop (1946).

\section{Cretaceous Rocks}

\section{Mesaverde Group}

Definition

The Mesaverde group of Late Cretaceous age was named by Holmes $(1877$, p. 252). The name was applied to the thick sequence of sandstone, shale, and coal that forms Mesa Verde in southwestern Colorado. Collier $(1919$, p. 296-297) divided the type sequence into three formations. In ascending order these are the Point Lookout sandstone, Menefee formation, and Cliff House sandstone. The Mesaverde 
group has been mapped continuously from the type region in Colorado across the San Juan Basin into the present area (Bauer, 1916, pl. 64; Reeside, 1924, p. 13-16; Dane, 1936, p. 93-109).

Because of the complexity of the stratigraphy of the Mesaverde group and the consequent uncertainty of correlations, earlier workers in the southern and eastern parts of the San Juan Basin did not use the formational subdivisions (Point Lookout, Menefee, and Cliff House formations) of the type region. The Mesaverde rocks in the southeastern part of the present area were mapped by Renick (1931), Dane (1936), and Wood and Northrop (1946) as the Mesaverde formation. In this region Dane mapped a basal sandstone which he correlated with the upper part of the Hosta sandstone member of the Mesaverde formation of the southern San Juan Basin. Above the Hosta sandstone member is a sequence of interbedded sandstone, shale, and coal beds which Dane correlated with the Gibson coal member and the Allison member of the Mesaverde formation of the southern San Juan Basin. The highest unit of the Mesaverde in the eastern part of the basin is a ledge-forming group of sandstone beds which Dane (1936, p. 108) named the La Ventana sandstone member of the Mesaverde formation.

Beaumont, Dane, and Sears (1956) revised the nomenclature of the Mesaverde group of the San Juan Basin. The Mesaverde was raised to group status everywhere. The Hosta sandstone of the eastern San Juan Basin was correlated with the Point Lookout sandstone. The Gibson 
and Allison members were made the Cleary and Allison members of the Menefee formation. The La Ventana sandstone was redefined as a tongue of the Cliff House sandstone.

The present writer did not subdivide the Mesaverde group into Point Lookout sandstone, Menefee formation, and La Ventana sandstone during reconnaissance mapping of these rocks. However, a three-fold division of the Mesaverde group was observed at all localities where the group is completely exposed in the eastern part of the area, and a threefold nature is apparent in electric logs of wells.

\section{$\underline{\text { Extent and Thickness }}$}

The Mesaverde group is exposed nearly continuously from south to north along the eastern edge of the area and is continuously distributed in the subsurface of the region west of the mountains.

In the southern part of T. 20 N., R. 1 W. the Mesaverde group is well exposed south of San Pablo Canyon where its upper beds, equivalent to the La Ventana tongue of the Cliff House sandstone, form a high hill on the crest of a northwest-plunging anticline. Beneath the La Ventana are slope-forming carbonaceous shale and sandstone of the Menefee formation underlain by thin sandstone of the Point Lookout. North of here the Mesaverde group is involved in the sharp folding at the foot of Sierra Nacimiento and San Pedro Mountain. The Mesaverde beds dip steeply to the west, and in places are vertical, or are ovex- 
turned slightly and dip to the east at high angles. Because of the steep dips the outcrop bejlt of the Mesaverde is narrow along the foot of the mountains. In the San Pedro Foothills the Mesaverde is covered by Quaternary gravel at places.

North of Sañ Pedro Mountain the westward dip of the Mesaverde becomes less steep a. the outcrop belt is wider. A thick upper sandstone unit, probably equivalent to the La Ventana tongue of the Cliff House sandstone, forms the high eastern hogback in the Northern Hog back Belt. Rocks probably equivalent to the Menefee formation and Point Lookout sandstone form steep slopes and small ridges east of the main hogback.

According to Renick (1931, p. 43-44) the Mesaverde is about 500 feet thick in sec. $35, T .21$ N., R. 1 W. The "lower sandstone member" of Renick is the Point Lookout sandstone which is about 180 feet thick. The "middle coal-bearing member" is the Menefee formation which is about 347 feet thick. The "upper sandstone member" is the La Ventana tongue of the Cliff House sandstone which is about 37 feet thick. Farther west in the subsurface, the thickness of the entire Mesaverde group increases to about 840 feet at the Sun McElvain well in sec. 23, T. 21 N. R. $2 \mathrm{~W}$. In the southwestern part of the area the Shell Oil Co. No. 1 Pool Four well in sec. 22, T. 21 N., R. 5 W. penetrated nearly 1,700 feet of rocks assigned to the Mesaverde group. 
In the northeastern part of the area the entire Mesaverde group is about 630 feet thick in the subsurface at the Reading and Bates No. 1 Duff well in sec. 24, T. 24 N., R. 1 W. Fitter (1958, p. 19, and p. 49-51) reports that the Mesaverde group is 647 feet thick in sec. 5, T. 24 N., R. 1 E., where the basal (Point Lookout) sandstone is approximately 95 feet thick, the medial coal-bearing sequence (Menefee formation) is about 375 feet thick, and the upper sandstone (La Ventana tongue of the Cliff House) is about 110 feet thick.

\section{$\underline{\text { Lithology }}$}

The Point Lookout sandstone consists of buff, gray, and tan sandstone beds ranging in thickness from 1-30 feet. The Point Lookout is mainly medium grained but contains a few beds of fine-grained sandstone and also some beds of shale.

The Menefee formation consists of shale and interbedded sandstone and thin coal beds. The shale is light to dark gray and usually carbonaceous, containing at places lenses of coal and coaly shale. The sandstone beds are white, gray, buff, and brown, lenticular streamchannel deposits of fine- to coarse-grained quartz sand.

The La Ventana tongue of the Cliff House sandstone consists of gray, buff, and orange-brown sandstone with some interbedded thin gray shale. The lower part of the La Ventana at most places consists of several beds of medium-grained sandstone as much as 30 feet thick. 
The upper part of the unit at most places consists of thinner, tan to orange-brown, fine-to medium-grained sandstone with gray shale inte rbedded.

The lithology, stratigraphic relations, and fossils of the Mesaverde group indicate that most of it was deposited during a major retreat and readvance of the Cretaceous sea across the region of the present San Juan Basin. The Point Lookout sandstone was deposited mainly as near-shore marine sand during the retreat of the sea. The Menefee formation is a terrestrial deposit laid down mainly when the strandline of the sea was north of the area of the present report. The La Ventana tongue of the Cliff House sandstone was deposited in a near-shore marine environment as the Cretaceous sea advanced southwestward back across the San Juan Basin.

\section{Contacts}

The Point Lookout sandstone is gradational into the underlying Mancos shale of Late Cretaceous age. This gradation occurs in a thin zone at the base of the Point Lookout where thin torgues of the Point Lookout sandstone are interbedded with thin tongues of the Mancos shale. The contact of the Point Lookout and the overlying Menefee formation is generally sharp but appears to be conformable. The contact of the Menefee formation and the overlying La Ventana tongue of the Cliff House sandstone appears to be gradational and there may be considerable intertonguing between the units locally. 
The contact of the La Ventana and the overlying Lewis shale of

Late Cretacêous age is gradational by intertonguing. The intertonguing relationship made reconnaissance mapping of the contact difficult. The top of the Mesaverde group was mapped arbitrarily as the top of the highest ledge-forming thick sandstone of the La Ventana tongue. This arbitrarily assigned contact is not at the same stratigraphic position across the area. At some places, particularly in the southern part of T. 20 N., R. 1 W., thin sandstone beds are intercalated in thick gray shale arbitrarily assigned to the lower part of the Lewis shale. These sandstone beds thicken to the south and merge into the upper part of the La Ventana as the intervening shale beds wedge out southward. Thus, the top of the La Ventana tongue becomes stratigraphically higher southward. The contact shown on the geologic map (Fig. 2) cuts across lithologic boundaries and, to the south, is slightly higher stratigraphically than in areas farther north.

Age

According to Reeside (1924, p. 16) the flora and invertebrate faunas of the Mesaverde are of Montana age, thus the age of the Mesaverde is about middle Late Cretaceous.

\section{Lewis Shale}

Definition

The Lewis shale of Late Cretaceous age was named by Cross, 
Spencer, and Purington (1899, p. 4) for exposures near Fort Lewis,

Colorado. The thick body of gray shale with some interbedded thin, fine-grained sandstone and nodular lime stone beds that rests on the Mesaverde group throughout the present area was mapped as Lewis shale by Renick (1931), Dane (1936), and Wood and Northrop (1946).

\section{Extent and Thickness}

The Lewis shale is exposed in a belt adjacent to and west of the Mesaverde group, and the structural attitudes of the units are similar. The Lewis shale is exposed in a wide area in T. 20 N., R. 1 W. where it is folded on a northwestward-plunging anticline. The outcrop belt becomes narrower to the north, and in the San Pedro Foothills steeply-dipping soft rocks of the Lewis shale are discontinuously exposed. In the Nor thern Hogback Belt the Lewis shale dips steeply to the west and crops out on low hills rising above alluviated valleys west of the Mesaverde hogback.

Renick (1931, p. 50) measured a section from the top of the Mesaverde to the base of what he classified as the Puerco formation in secs. 2 to $4, T, 20$ N., R, 1 W., and gave a thickness of about 1,660 feet for the Lewis. Renick probably included in the upper part of the Lewis shale rocks which Dane (1936) mapped as the Kirtland shale, and which the present writer has mapped as the Pictured Cliffs sandstone of Late Cretaceous age and the undivided Fruitland formation and Kirtland 
shale also of Late Cretaceous age. The Pictured Cliffs and the undivided Fruitland and Kirtland are about 170 feet thick in secs. 8 and 9, T. 20 N., R. 1 W. Thus, the Lewis shale as mappéd by the present writer is about 1,490 feet thick in the southeastern part of the area. The Sun Oil Co. No. 1 McElvain well drilled in sec. 23, T. 21 N. , R. 2 W. penetrated about 1,530 feet of Lewis shale. Dane (1936, p. 111) estimated the thickness of the Lewis to be from 550 to 600 feet south of Mesa Piedra Lumbre (Mesa Portal on Fig. 2 of the present report). In the southwestern part of the area the Shell Oil Co. No. 1 Pool Four well in sec. 22, T. 21 N., R. 5 W. penetrated about 500 feet of sandy shale assigned to the Lewis.

In the north-central part of the area the Magnolia Petroleum Co. No. 1 Jicarilla $\mathrm{D}$ well in sec. $24, \mathrm{~T} .26 \mathrm{~N} ., \mathrm{R} .3 \mathrm{~W}$. penetrated about 1,470 feet of shale assigned to the Lewis. In the northeastern part of the area the Reading and Bates No. 1 Duff well in sec. 24, T. 24 N., R. 1 W. penetrated about 1,900 feet of Lewis shale. From the se figures it is apparent that the Lewis shale thins from northeast to southwest. Much of this thinning takes place in a short distance in the subsurface of the southwestern part of the area. The rapid thinning occurs also at the surface south of the area, and both Renick (1931, p. 44-45) and Dane (1936, p. 109-111) recognized that the thinning was largely the result of a facies change. Most of the Lewis shale intertongues with and grades 
laterally into the upper part of the La Ventana tongue of the Cliff House sandstone. Thus, as the Lewis becomes thinner to the south the La Ventana becomes thicker.

\section{Lithology}

The Lewis shale is composed of light-to dark-gray fissile clay shale with a small proportion of interbedded siltstone, fine-grained sandstone, and nodular concretionary limestone. At most places about the lower 100 feet of the Lewis shale contains several thin beds of sandstone. Some of these beds can be traced laterally into the La Ventana tongue of the Cliff House sandstone; thus, the lower part of the Lewis is a zone of intertonguing between the Lewis and the Mesaverde group.

At places, thin beds of fine-grained sandstone were observed to become calcareous as they were traced northward, and to grade laterally into thin highly fossilife rous concretionary lime stone beds. In the Northern Hogback Belt a thin concretionary limestone forms a persistent marker bed which holds up small low ridges rising above the valleys carved in the Lewis. This limestone contains numerous well-preserved shells of ammonites, gastropods, and pelecypods. The stratigraphic position of this marker bed is near the base of the upper one-third of the Lewis shale. Thin limestone and calcareous siltstone beds occur at other stratigraphic positions also.

In the subsurface of the southwestern part of the area the Lewis 
shale is very sandy and silty. In this region the Lewis is only 500600 feet thick, and these beds are believed to be stratigraphically equivalent to the clay shale of the upper part of the Lewis of the northern part of the area. The stratigraphic interval represented by the upper $800-1,000$ feet of the Mesaverde group in the subsurface of the southwestern part of the area is probably equivalent stratigraphically to the lower $800-1,000$ feet of clay shale of the Lewis of the northern part of the area.

The contained marine invertebrate fossils and the lithology of the Lewis shale indicate that it was deposited in an off-shore environment after the southwestward advance of the Cretaceous sea during which the lower part of the La Ventana tongue of the Cliff House sandstone was deposited. Most of the Lewis shale in the east-central part of the San Juan Basin was deposited at a time when the strandline of the Cretaceous sea was southwest of the present area of investigation. The thick tongues of the upper part of the La Ventana sandstone were deposited as beds of near-shore marine sand which grade northward into the deeper water shale deposits of the Lewis.

\section{Contacts}

The contact of the Lewis shale and the uncerlying Mesaverde group is tramitional and intertonguing. The contact of the Lewis shale and the overlying Pictuxed Cliffs sandstone also is transitional and intertonguing. In the subsurface of the southwestern part of the area 
an intertonguing relationship causes the top of the Lewis shale to rise stratigraphically to the northeast as the lower part of the Pictured Cliffs tongues out in that direction (Fig. 5). Similar intertonguing relationships are apparent also at the surface in the southeastern part of the area. In the SW $1 / 4$ sec. $25, T .20$ N., R. 2 W. the Pictured Cliffs is about 65 feet thick and contains a few beds of shale. Toward the northeast in the NW $1 / 4$ sec. $20, T, 20 \mathrm{~N} ., \mathrm{R}, 1 \mathrm{~W}$. the lower part of the Pictured Cliffs is represented by only a few thin tongues of sandstone interbedded with thick beds of shale. In this area very thin beds of sandstone occurring in the upper part of the Lewis shale are probably tongues of the Pictured Cliffs.

Farther north on the outcrop the Pictured Cliffs is represented by several beds of fine-grained sandstone and interbedded shale lying conformably on the Lewis shale. North of sec. 23, T. 21 N., R. 1 W., the zone of sandy shale and shaly sandstone equivalent to the Pictured Cliffs sandstone is included with the undivided Fruitland formation and Kirtland shale because the beds equivalent to the Pictured Cliffs are too thin to map separately at the scale of Figure 2. However, the thin zone of sandy shale and shaly sandstone equivalent to the Pictured Cliffs and resting conformably on the Lewis persists in the outcrop and the subsurface to at least the northern edge of the area.

\section{Age}

The Lewis shale contains a fauna equivalent to part of the upper 
and middle portion of the Pierre shale of the Great Plains region (Reeside, 1924, p. 18) and is of Late Cretaceous (Montana) age.

Pictured Cliffs Sandstone

Definition

The Pictured Cliffs sandstone of Late Cretaceous age was named by Holmes (1877, p. 248). The name was applied to the massive ledges of marine sandstone exposed north of the San Juan River west of Fruitland, New Mexico. Reeside (1924, p. 18) redefined the formation to include the massive sandstone ledges of Holmes and the sequence of interbedded shale and sandstone beneath them and above the Lewis shale. The Pictured Cliffs sandstone crops out in a nearly continuous narrow band around the northern, western, and southern sides of the Central basin, and has been mapped continuously by other investigators (Bauer, 1916; Reeside, 1924; Dane, 1936) from the type locality into the southern part of the present area of investigation. The Pictured Cliffs is the stratigraphically lowest formation that was studied in detail during the present investigation.

\section{Extent and Thickness}

The Pictured Cliffs sandstone crops out above the Lewis shale in the southeastern part of the axea, and a zone of thin sandstone, siltstone, and interbedded shale believed to be equivalent to the Pictured Cliffs was 
traced along the eastern side of the area as far north as sec. 4, T. 25 N., R. 1 E. The Pictured Cliffs is present in the subsurface of most of the area. In the southern part of T. 20 N., R. 2 W., the lower part of the Pictured Cliffs forms low, gently sloping benches of rusty-weathering sandstone above the Lewis shale. The upper part forms steep slopes and cliffs of soft sandstone in the lower part of the erosional escarpment at the eastern side of Mesa Portal. On the southern slope of the butte in the SW $1 / 4$ sec. $25, T .20$ N., R. 2 W., the Pictured Cliffs is about 65 feet thick. To the northeast the Pictured Cliffs is covered by alluvium in the valley of the Rio Puerco.

Dane $(1936$, p. 112; 1946) reported that the Pictured Cliffs sandsone is not present east of the Rio Puerco. However, the formation is present and recognizable in secs. 17, 19, and 20, T. 20 N., R. 1 W., although its beds are thin and poorly exposed at places. In this part of the area the Pictured Cliffs forms small, sloping benches at the foot of the mesa northwest of the broad, sloping valley cut in Lewis shale by Senorito Creek. In the NW 1/4 sec. $2 Q$, T. 20 N., R. 1 W. the Pictured Cliffs is about 60 feet thick. The lower 35 feet is silty shale containing thin beds of concretionary siltstone and sandstone. The upper part consists of sandstone and some interbedded carbonaceous shale, all about 25 feet thick, and forming small ledges.

Northward from sec. 17, T. 20 N., R. 1 W., to about the center of sec. 23, T. 21 N., R. 1 W., the Pictured Cliffs sandstone is about 
45 feet thick, and consists of clay shale and interbedded thin, rustyweat hering concretionary sandstone and siltstone overlain by soft, thin, shaly carbonaceous sandstone.

In the San Pedro Foothills and in the Northern Hogback Belt this sequence of shale, concretionary siltstone and sandstone, and overlying shaly carbonaceous sandstone is exposed at many places, and was found at other places by digging through a thin soil cover. In this region the thickness of the Pictured Cliffs varies, but averages about 35 feet. North of sec. 23, T. 21 N., R. 1 W., the Pictured Cliffs dips steeply to the west or is vertical or overturned slightly, and its outcrop belt is very narrow. For this reason the Pictured Cliffs north of sec. 23, T. $21 \mathrm{~N}$. , R. 1 W., was not mapped as a separate unit, but was included with the overlying undivided Fruitland formation and Kirtland shale, although the Pictured Cliffs is a recognizable unit as far north as sec, 4, T. 25 N., R. 1 E.

In a landslide scar in the NE $1 / 4$ sec. 4, I. 25 N., R. 1 E., the rocks equivalent to the Pictured Cliffe are about 58 feet thick, and are sandy or silty shale and several thin beds of silty fine-grained sandstone containing carbonized plant fragments. Here the entire Pictured Cliffs interval has become little more than a sandy zone at the top of the Lewis, and from this area north it was exciuded from the undivided Fruitland formation and Kirtland shale, and was mapped with the Lewis shale. 
The Pictured Cliffs sandstone is widely distributed in the subsurface of the area as determined by a study of electric logs of wells drilled for oil and gas (Figs. 5-7). The Pictured Cliffs is about 235 feet thick at the J. D. Hancock No. 1 well in sec. $33, T .21$ N., R. $5 \mathrm{~W}$. The thickness diminishes northeastward because of the wedgeout of the lower part of the Pictured Cliffs into the upper part of the Lewis shale, and the Pictured Cliffs is only about 100 feet thick at the Humble Oil and Refining Co. No. 1 Jicarilla B well in sec. 22, T. 22 N., R. $5 \mathrm{~W}$. Northeastward from this well the thickness diminishes gradually because thin sandstone tongues of the lower part of the Pictured Cliffs wedge out into the upper part of the Lewis, and also because of depositional thinning of the Pictured Cliffs. At the Magnolia Petroleum Co. No. 1 Cheney-Federal well in sec. 8, T. 26 N., R. 2 W., a zone of interbedded shaly sandstone, siltstone, and interbedded silty, sandy shale about 80 feet thick is correlated with the Pictured Cliffs sandstone.

In the subsurface of the eastern part of the area the Pictured Cliffs thins rapidly to the north as it does in outcrops, but a thin zone of sandy shale and shaly sandstone persists to the north as it does in the outcrops. Because of the exaggerated vertical scale of the correlation diagrams (Figs. 5,6, and 7) it is possible to show the Pictured Cliffs of the mbsurface as 4 marate unit even where it is thin, and it is not combined with the undivided Fruitland formation and Kirtland shale in the diagrams. 
The thickness of the Pictured Cliffs sandstone in the subsurface

tends to be more or less constant across the area in a north-northwest direction. The main direction of thinning. is from west-southwest to east-northeast.

\section{$\underline{\text { Lithology }}$}

The Pictured Cliffs sandstone is composed of varying proportions of thin- to thick-bedded sandstone, siltstone, and shale. In the subsurface of the southwestern part of the area the Pictured Cliff is mainly sandstone, but contains beds of siltstone and shale. Northeastward the Pictured Cliffs thins and, as judged by interpretation of electric logs of wells, the thinning is accompanied by a gradual change from a predominantly sandstone facies to a facies of thin, argillaceous, fine-grained sandstone, siltstone, and interbedded shale.

At the surface west of the Rio Puerco in the southeastern part of the area, the Pictured Cliffs is about 65 feet thick, and is composed mainly of very fine grained to medium-grained sandstone (Fig. 3). In the SW $1 / 4 \mathrm{sec} .25$, T. 20 N., R. 2 W., the lower part of the Pictured Cliffs is mainly soft yellowish-brown to buff sandstone about 15 feet thick. The middle part of this sandstone is tangentially cross bedded, and forms rusty-weathering ledges. Above the sandstone is olive-colored soft clay shale, about 5 feet thick, overlain by soft sandstone and interbedide poorly exposed shale about 10 feet thick. The upper part of the Pictured 
Cliffs is about 35 feet thick and consists of two beds of fine - to mediumgrained, slightly micaceous sandstone separated by a 3 -foot bed of gray clay shale. The Pictured Cliffs is overlain by, soft, argillaceous, shaly, carbonaceous to coaly sandstone assigned to the undivided Kirtland shale and Fruitland formation. The upper part of the Pictured Cliffs was traced southwestward outside the area to sec. $7, T$. 19 N., R. 2 W. At this locality it seems to be equivalent to a sandstone, 71 feet thick, which Dane (1936, p. 116) described in a stratigraphic section as being the basal sandstone of the Kirtland shale (Fig. 3). However, the writer found casts of Halymenites in this sandstone, indicating its marine origin and indicating that it is part of the Pictured Cliffs. Here the total thickness of the Pictured Cliffs is about 116 feet. East of the Rio Puerco in the southeastern part of the area the sandstone beds of the lower part of the Pictured Cliffs become very thin, fine grained, and somewhat concretionary. The sandstone at the base of the formation in the NW $1 / 4 \mathrm{sec}, 20, T .20 \mathrm{~N} ., \mathrm{R} .1 \mathrm{~W}$. is about 2. 5 feet thick and, at places, forms brown-weathering concretions. Above the basal sandstone is light-to dark-gray sandy shale, about 35 feet thick, containing thin concretionary siltstone and sandstone beds. The upper part of the Pictured Cliffs is about 22.5 feet thick and consists of two beils of fine-to medium-grained sandstone interbedded with shale. Above the Pictured Cliffs at this locality is olive-gray, carbonaceous, very sandy clay shale and thin sandstone containing marine 
fossils, and about 15.5 feet thick. These rocks are probably equivalent to the carbonaceous shale and sandstone of the lower part of the Fruitland and Kirtland formations west of the Rio Puerco. They are overlain by a dark- brown-weathering, medium-grained to very coarse grained sandstone, 2.5 feet thick, which forms a brown ledge at the base of higher beds of the undivided Fruitland formation and Kirtland shale. Many of the beds of the Pictured Cliffs contain lignitized fragments of fossil plants which are scattered through the rock and form thin mats on bedding planes. The carbonaceous material is associated with marine invertebrate fossils, and characterizes the Pictured Cliffs on the eastern side of the area.

The Pictured Cliffs in the SW $1 / 4 \mathrm{NW} 1 / 4 \mathrm{sec} .23, \mathrm{~T}, 21 \mathrm{~N}$. , R. 1 W. has at its base a brown-weathering, concretionary, calcareous siltstone about 1.5 feet thick. Above this is soft carbonaceous sandy shale and interbedded thin, lenticular, fine-grained sandstone, all about 33. 5 feet thick. Above this is soft fine-to medium-grained carbonaceous sandstone alternating with carbonaceous sandy and silty clay shale containing thin lenses of fine-grained sandstone. The sandstone and sandy shale beds range in thickness from 2.5 to 7 feet, and the.total thickness of the upper part of the Pictured Cliffs is about 28 feet. The Pictured Cliffs is overlain by a soft yellowish buff sandstone 14.5 feet thick which is assigned to the undivided Fruitland formation and Kirtland shale. North of this locality, in the San Pedro Foothills and Northern 
Hogback Belt, the lithology of rocks equivalent to the Pictured Cliffs (but mapped with the overlying Fruitland and Kirtland) is generally similar to that of the sequence described above. At most places these rocks consist of a lower unit of shale and interbedded thin rustyweathering, concretionary sandstone 20-25 feet thick, and an upper unit of two or more soft, fine-grained, shaly sandstones whose combined thickness is $15-20$ feet. In sec. 4, T. 25 N., R. 1 E. rocks equivalent to the Pictured Cliffs consist of shale with several thin beds of siltstone and fine-grained sandstone containing plant fragments. North of this locality the se rocks are mapped with the Lewis shale. The lithology and marine fossils contained in the Pictured Cliffs sandstone indicate that it was deposited in near-shore and offshore marine environments at a time when the shoreline of the Cretaceous sea was mainly southwest of the area investigated. At places in the San Pedro Foothills, notably at the outcrops in sec. 23, T. 21 N., R. 1 W., part of the Pictured Cliffs sandstone consists of thin, highly lenticular bodies of fine-grained sand interbedded with highly carbonaceous siltstone and clay shale containing abundant lignitized plant fragments. The lenticular sand bodies range in thickness from less than 1 inch to as much as 7 feet. The lateral extent of the lenses ranges from a few inches to hundred of feet, but many of the lenses are only a few inches to a few feet in length. The lithology of these rocks is strikingly similar to that of sediments accumulating on 
extensive tidal flats at the edge of the North Sea in northern Germany. These sediments are described and illustrated with a core by Hantzschel (1939, p. 197-203). According to Hantzschel, the tidal mud consists of soft, unctuous, water-soaked slime composed mainly of fine silt and clay containing a small amount of sand and shell fragments of various invertebrates. Fine plant detritus also is present, and excrement of marine organisms causes the unctuous character of the mud. The deposits are stratified, with intercalations of thin layers of fine sand in the argillaceous substance. The bedding is seldom strictly parallel, but is streaky and lenticular. The alternating layers wedge out rapidly and their thickness is not uniform. The irregular bedding is caused by frequent reworking of the sediments by tidal and wind-driven currents of varying strength and direction.

If the similarity of the lenticular sandstone and carbonaceous shale of the Pictured Cliffs and the North Sea tidal-flat sediments is meaningful, it may indicate that part of the region of the Nacimiento uplift was slightly emergent or was a shoal area during deposition of the Pictured Cliffs.

No evidence was found to indicate that the region of the Nacimiento uplift contributed much if any sediment to the Pictured Cliffs sea. Most of the sediment of the Pict u red Cliffs sandstone in this part of the basin probably was derived from the region southwest and west of the San Juan Basin. Dane (1946) found that the Pictured Cliffe 
sandstone of the northern part of the basin pinches out southward along the northeastern side of the basin, indicating that highlands had arisen north of the San Juan Basin, and deposition of the Pictured Cliffs took place in a restricted, northwest-trending embayment of the Cretaceous sea (Fig. 10). Sediments of the Pictured Cliffs in the northeastern part of the basin were derived from areas north and northeast of the basin.

\section{Contacts}

The Pictured Cliffs sandstone rests conformably on the Lewis shale and intertongues with it. In the subsurface, and at the surface west of the Rio Puerco in the southeastern part of the area, the Pictured Cliffe is overlain conformably by carbonaceous to coaly shale and thin sandstone and siltstone which are the basal parts of the undivided Fruitland formation and Kirtland shale. Also, at many places north of sec. 20, T. 24 N., R. $1 \mathrm{E}$, rocks equivalent to the Pictured Cliffs are overlain conformably by sandy carbonaceous shale containing silicified wood and thin, rusty-weathering siltstone and fine-grained sandstone. These beds, 15 to 30 feet thick, are believed to be equivalent to persistent thin, carbonaceous, shaly beds above the Pictured Cliffs in the subsurface and to the soft carbonaceous shale and sandstone of the Fruitland and Kirtland at the surface west of the Rio Puerco. These carbonaceous shale beds seem to be absent at most places where the Fruitland and Kirtland are exposed in the San Pedro Foothills. At many of these places, rocks equivalent to the Pictured Cliffs are overlain 


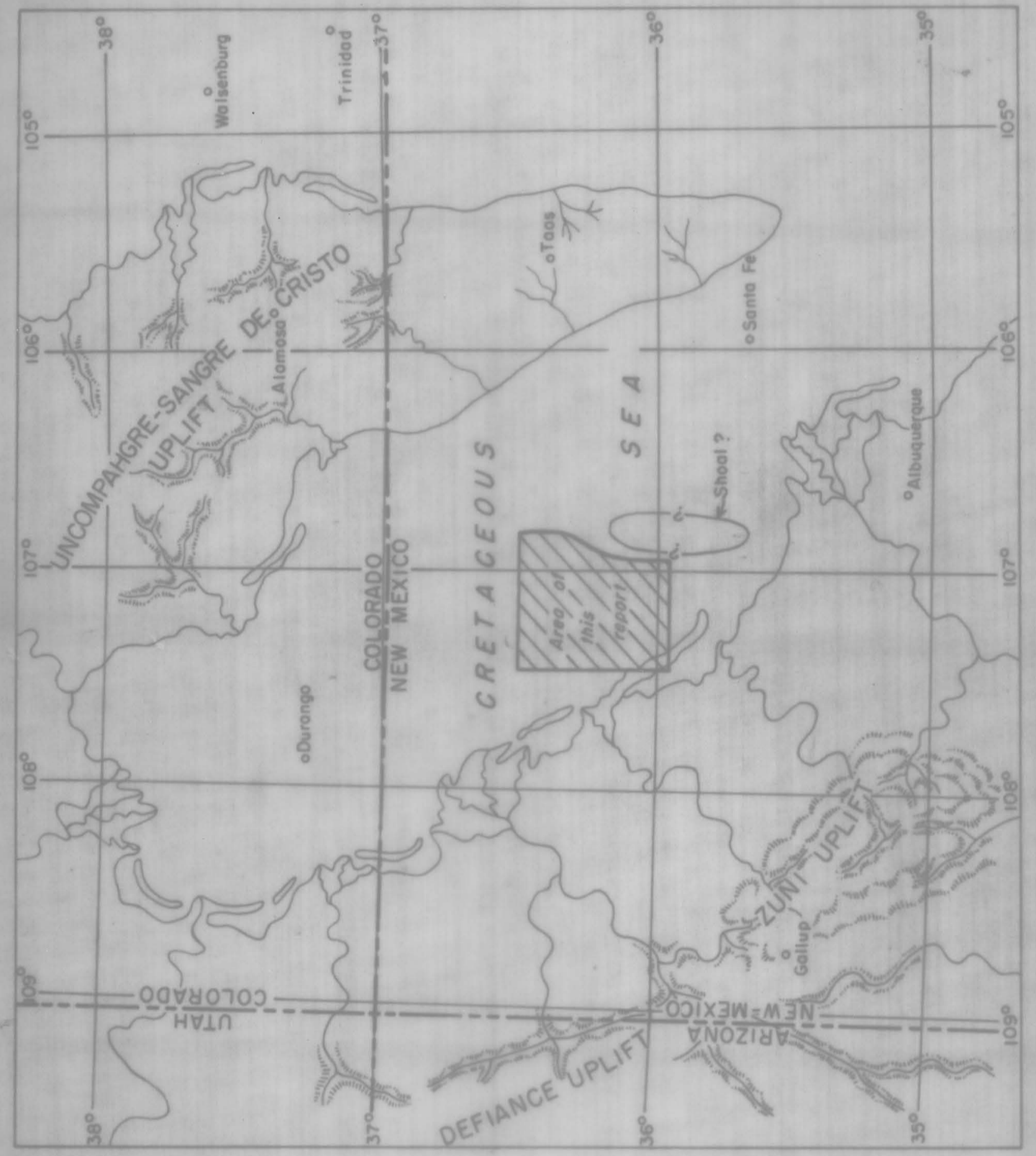

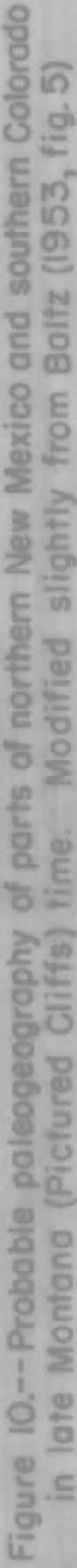


with slight erosional unconformity by thin to thick, coarse-grained sandstone whose stratigraphic position in the Fruitland and Kirtland is higher than the carbonaceous shale. Locally, the upper part of the rocks equivalent to the Pictured Cliffs is thin or absent. These relations may be the result of slight local unconformity caused by scouring or channeling, and seem to indicate that silight uplift or folding occurred in the San Pedro Mountain area not long after deposition of the Pictured Cliffs.

Age

According to Reeside (1924, p. 19) the Pictured Cliffs in the western part of the Central basin contains a littoral marine fauna of late Montana (Late Cretaceous) age. Fossils collected from the Pictured Cliffs south of the present area of investigation also were considered to be of Montana age by Reeside (Dane, 1936, p. 112).

Fruitland Formation and Kirtland Shale, Undivided Definition

Lying on the Pictured Cliffs sandstone throughout the area is a thin but stratigraphi cally complex sequence of sandy carbonaceous shale, siltstone, fine-to coarse-grained sandstone, and some bentonitic shale. Gardner (1909, pl. 1) and Renick (1931) apparently included part of these rocks with the underlying Lewis shale, and part of them with overlying rocks assigned by them to the Puerco formation. Dane (1936, p. 112) 
found that these rocks are equivalent to rocks mapped on the western side of the Central basin by Bauer and Reeside (1921) and Reeside (1924) as the Fruitland formation and Kirtland shale. The Fruitland formation, which lies conformably on the Pictured Cliffs sandstone, consists of varied proportions of interbedded sandstone, shale, and coal. The formation was named by Bauer (1916, p. 274) for exposures near Fruitland, New Mexico on the San Juan River. The Kirtland shale, which lies on the Fruitland formation, consists of varied proportions of sandstone and shale similar to the Fruitland formation but containing little or no coal. The Kirtland shale was named by Bauer (1916, p. 274) for exposures along the San Juan River between Kirtland and Farmington, New Mexico. Here the Kirtland was subdivided by Bauer into a lower shale member, the medial Farmington sandstone member, and an upper shale member.

Dane (1936) mapped the Fruitland and Kirtland across the southern part of the Central basin and into the southern part of the present area of investigation. East of sec. 7, T. 19 N., R. 2 W. Dane (1936, p. 115, and pl. 39) arbitrarily combined the two formations and mapped them as the Kirtland shale, because the basis for distinguishing the two formations was said to become less evident eastward. However, because rocks probably equivalent to both the Fruitland formation and the Kirtland shale occur in the present area of investigation, the rocks mapped as Kirtland shale by Dane (1936) are designated in the present report 
as the undivided Fraitland formation and Kirtland shale.

\section{Extent and Thickness}

The undivided Fruitland formation and Kirtland shale are present above the Pictured Cliffs sandstone throughout the present area of investigation. Fruitland and Kirtland rocks crop out in the southwestern and southern parts of the area where they form low rounded hills and benches and steep slopes beneath cuestas held up by the overlying Ojo Alamo sandstone of Tertiary(?) age. West of the present area, in T. 20 N., R. 6 W., the combined thickness of the Fruitland and Kirtland was estimated to be slightly less than 600 feet (Dane, 1936 , p. 114). The sequence thins eastward, and in the NW $1 / 4$ sec. 25 and NE $1 / 4$ sec. 26, T. 20 N., R. 2 W. the Fruitland formation and Kirtland shale are about 246 feet thick. In the SE $1 / 4 \mathrm{NE} 1 / 4 \mathrm{sec} .8$ and SW $1 / 4$ NW $1 / 4$ sec. 9, T. 20 N., R. 1 W. the sequence is 126 feet thick.

Dane (1936) mapped the combined Fruitland and Kirtland formations as the Kirtland shale from T. 19 N., R. 2 W. into T. 21 N., R. $1 \mathrm{~W}$. From there northward, laterally equivalent beds were said by Dane (1946) to be included in the Lewis shale as far north as the southern part of T. 25 N., R. 1 E. However, detailed examination and mapping of outcrops in the San Pedro Foothills and Northern Hogback Belt by the present writer indicate that, throughout this area, the undivided Fruitland formation and Kirtland shale are a persistent lithologic unit which is differentiated easily from the underlying Lewis shale. 
Judging from Dane's (1946) stratigraphic sections measured in $T$. 2324 N., R. 1 W., and T. $24-25$ N., R. 1 E., beds which he included at different places in the upper part of the Lewis shale and the Ojo Alamo sandstone, and in the lowest parts of the Nacimiento formation of Tertiary age and the Animas formation of Cretaceous and Tertiary age, are equivalent to the unit mapped by the present writer as the undivided Fruitland formation and Kirtland shale. As previously discussed, thin beds equivalent to the Pictured Cliffs sandstone north of sec. 23, T. 20 N., R. $1 \mathrm{~W}$. were mapped also with the Fruitland and Kirtland by the present writer.

In the San Pedro Foothills the Fruitland and Kirtland rocks dip very steeply to the west, or locally are vertical or overturned slightly, and form a narrow, discontinuously exposed belt of soft, rounded sandstone ledges with intervening thin to thick beds of soft dark-gray and olive-green shale. In the Northern Hogback Belt the sequence dips steeply to the west and forms low ridges and slopes west of the slopes and valleys cut in the Lewis shale. The thickness of the undivided Fruitland formation and Kirtland shale is varied because of slight angular discordance and erosional unconformity with the overlying Ojo Alamo sandstone, In the NW $1 / 4 \mathrm{SE} 1 / 4 \mathrm{sec}, 11, \mathrm{~T}, 21 \mathrm{~N} ., \mathrm{R}, 1 \mathrm{~W}$. the sequence is about 128 feet thick, including at the base 27 feet of sandstone and shale equivalent to the Pictured Cliffs sandstone. On the north side of San Jose Creek in the SW $1 / 4 \mathrm{NE} 1 / 4$ sec. $34, T .23 \mathrm{~N}$., 
R. $1 \mathrm{~W}$. the sequence is about 220 feet thick, including about 31 feet of sandstone and shale equivalent to the Pictured Cliffs. South of Almagre Arroyo in the NE $1 / 4$ sec. 2, T. 23 N., R. 1 W. the undivided Fruitland formation and Kirtland shale a re about 84 feet thick, including 33 feet of poorly exposed sandstone and shale equivalent to the Pictured Cliffs .

North of sec. 20, T. 24 N., R. 1 E. the undivided Fruitland and Kirtland thicken, and near the center of sec. $8, T, 24$ N., R. 1 E. they are about 200 feet thick, including 46 feet of poorly exposed sandstone and shale equivalent to the Pictured Cliffs. North of here the sequence thickens and thins. It is about 280-300 feet thick, including 35 feet of poorly exposed beds equivalent to the Pictured Cliffs, in the NE $1 / 4 \mathrm{NW} 1 / 4$ sec. 29 and NE $1 / 4$ sec. 17, T. 25 N., R. 1 E. Farther north in T. 26 N., R. 1 E., the sequence is less than half this thickness, because upper beds are cut out by an unconformity at the base of the overlying Ojo Alamo sandstone.

In the subsurface of the part of the area east of the Continental Divide the thickness of the undivided Fruitland formation and Kirtland shale varies as it does in the outcrops. However, in the subsurface west of the divide, the sequence thickens irregularly westward. In the northwestern part of the area the sequence is about 450 feet thick at the Northwest Production Co. No. 1-7 Jicarilla 152 well in sec. 7, T. 26 N., R. 5 W. (Fig. 7). In the sub urface of the southwestern part of 
the area the sequence is 300-400 feet thick (Fig. 5).

The undivided Fruitland formation and Kirtland shale consist of varied proportions of dark- to light-gray and clive-green clay shale, bentonitic clay, sandy shale and siltstone, and interbedded white, buff, brown and greenish-gray, fine-grained to very coarse grained sandstone. Carbonaceous to coaly shale is present locally in the lower part. At many places on the southern and eastern sides of the area the sequence consists of three more or less distinguishable lithologic units. These units, called units $A, B$, and $C$ in this report (Fig. 3) are believed to correlate generally with parts of the Fruitland formation and the Kirtland shale as mapped by Dane (1936) southwest of the present area. Inasmuch as the stratigraphy of these rocks is complex, the units are described in considerable detail in the following pages.

\section{Unit A}

The lower unit, which is probably equivalent to part of the Fruitland formation, rests conformably on the Pictured Cliffs sandstone, and is here called unit $A$ for convenience of discussion. At the surface in the southeastern part of the area, unit A consists of dark-gray, carbonaceous, silty, clay shale with interbedded thin sandstone and siltstone, and a few thin lenses and persistent beds of impure coal near the base. Unit $A$ is a little more than 50 feet thick in the stratigraphic section measured by Dane (1936, p. 116, beds $3-12$ from the base) 
in the SE $1 / 4 \mathrm{sec} .7$, T. $19 \mathrm{~N}$, , R. 2 W. (see Fig 3). On the outlying butte in the SW $1 / 4 \mathrm{sec} .25$, T. 20 N., R. 2.W. unit $A$ is about 28 feet thick.

In the San Pedro Foothills, unit A seems to be present but thin at some places and absent at other places. In the SW $1 / 4 \mathrm{NE} 1 / 4 \mathrm{sec}$. 27, T. 23 N., R. 1 W., beds of unit A are exposed on a low hill in the valley. Here unit $A$ contains a thin bed of concretionary-weathering fine-grained sandstone containing the marine pelecypod Inoceramus sp. This sandstone is believed to correlate with thick marine sandstone in unit A farther north. Similar thin, rounded-weathering, buff sandstone beds are present in outcrops on the abandoned Gallina highway in the center of sec. 22, T. 23 N., R. 1 W. where unit A is a little more than 60 feet thick and rests on rocks equivalent to the Pictured Cliffs (but mapped with the Fruitland and Kirtland).

Farther north, in the Northern Hogback Belt, unit $A$ is thinner than this at most places, but thickens locally in the NE $1 / 4 \mathrm{sec} .36$, T. $24 \mathrm{~N}$, , R. $1 \mathrm{~W}$, where it contains the thin marine sandstone. The unit thins to 10-30 feet in secs. 30,29 , and $20, T, 24$ N., R. I W. In this vicinity it is represented mostly by soft, yellowish, fine-to mediumgrained marine sandstone underlain by ironstone-bearing, dark-gray carbonaceous shale resting on rocks equivalent to the Pictured Cliffs. The marine sandstone is overlain unconformably at many places by 
coarse-grained sandstone of unit B of the Fruitland and Kirtland.

North of the center of sec. 20, T. 24 N., R. 1 E. unit A

thickens. At the center of sec. 8, T. 24 N., R. 1 E. the unit is about 200 feet thick. The lower part of unit A consists of silty, olive-gray shale about 25 feet thick, and the overlying marine sandstone has thickened to about 60 feet. The upper part of unit $A$ is covered. Farther north, in T. 25 N., R. 1 E. , unit $A$ is thinner, and the marine sandstone is overlain by coarse-grained sandstone of unit B of the FruitlandKirtland.

In the NW $1 / 4 \sec .29, T .25 \mathrm{~N} ., \mathrm{R}, 1 \mathrm{E}$. unit $\mathrm{A}$ is about 128 feet thick. Here it consists of lower beds of carbonaceous silty shale overlain by the thick marine sandstone which is poorly exposed, but is probably about 60 feet thick. It has some coarse grains and contains casts of Halymenites. The marine sandstone is overlain by dark-gray to olive-green carbonaceous shale overlain in turn by coarse-grained sandstone of unit B of the Fruitland and Kirtland. The rocks of unit A at this locality were considered by Dane (1946, stratigraphic section 7) to be in the upper part of the Lewis shale.

The stratigraphic sequence of unit $A$ is about the same at exposures on the ridge in the SE $1 / 4 \mathrm{NE} 1 / 4 \mathrm{sec} .17, \mathrm{~T}, 25 \mathrm{~N}, \mathrm{R} .1 \mathrm{E}$. where there are two thick beds of brown to light-olive weathering, Halymenites-bearing sandstone separated by a bed of silty shale. The total thickness of the two sandstone beds and included shale is about 85 feet. The 8 andstones are overlain by olive-colored and gray shaie 
with thin interbedded sandstone. This upper shaly part of unit $A$ is about 86 feet thick and is overlain by a hard ledge-forming, light-tan sandstone at the base of unit B. The thin sandstones in the upper shale of unit A thicken rapidly to the north from the point of measurement and, within a few hundred feet, most of the upper 86 feet of unit A consists of massive, ledge-forming, medium-to coarse-grained, cross-bedded sandstone. This sandstone, and the overlying hard, ledge-forming sandstone of unit B of the Fruitland and Kirtland, were included by Dane (1946, stratigraphic section 8) in the lower part of the Animas formation.

The sandstone of the upper part of unit $A$ and the basal sandstone of unit B, combined, form a prominent ledge, 60-100 feet thick, as far north as the center of sec. 4, T. 25 N., R. 1 E. where the upper part of unit $B$ is cut out by the Ojo Alamo sandstone which then rests on the sandstone beds of units A and B. From here north to the edge of the area the massive sandstone on the cuestas above the Lewis shale is composed of combined sandstone beds of the upper part of unit $A$, the lower part of unit B, and the Ojo Alamo.

The Halymenites-bearing sandstone of the lower part of unit A is concealed or very poorly exposed for almost 2 miles north of sec. 17, T. 25 N., R. 1 E. In the NW $1 / 4 \mathrm{NE} 1 / 4 \mathrm{sec}, 4, \mathrm{~T} .25 \mathrm{~N}$, , R. I E. the upper part of the Lewis shale and the overlying cliff-forming sandstones are well-exposed in a landslide scar. Here beds equivalent 
to the Pictured Cliffs sandstone are represented by several very thin sandstone beds intercalated with thick shale. Above this is a slopeforming, greenish-gray, soft, silty, shaly sandstone about 35 feet thick which probably represents the lower part of the Halymenitesbearing sandstone. This is overlain by sandy clay shale about 20 feet thick, in turn overlain by a bed of fine-grained sandstone 3.5 feet thick which may be part of the upper Halymenites-bearing sandstone. These beds are overlain by coarse-grained sandstone of the upper part of unit $\mathrm{A}$ which seems to rest on the ma rine sandstone with slight erosional unconformity. The soft sandy beds representing the lower part of unit A of the Fruitland and Kirtland were traced by their greenish color along the base of the overlying cliff-forming sandstones to the northern edge of the area.

\section{Unit B}

Resting with local erosional unconformity on unit $A$ is a sequence of rocks probably equivalent to part of the Kirtland shale. These rocks are informally called unit $B$ of the undivided Fruitland formation and Kirtland shale for convenience of discussion. The basal part of unit B is a fine-grained to very coarse grained sandstone, usually light yellowish gray or buff, cross bedded, and contains at many places large masses of gray and white silicified wood. This sandstone is composed mainly of angular to well--rounded quartz sand and granules, but at 
most places contains also grains of weathered pink and white feldspar, and pink and green rock fragments. At places, the sandstone contains small rounded gray, white, and red siliceous pebbles. The thickness of the sandstone varies considerably, ranging from only a few feet to as much as 75 feet. This basal sandstone of unit B seems to be continuously distributed along the eastern side of the area, but this conclusion cannot be demonstrated by tracing of the sandstone because of the discontinuity of outcrops.

Above the basal sandstone, the rocks of unit B consist mainly of light - to dark-gray, olive-green, and olive-gray clay shale with lesser amounts of interbedded white, buff, and yellow, fine-grained to very coarse grained lenticular sandstone. Much of the clay is silty and sandy, and the sandstone and clay beds intergrade vertically and horizontally. Some of the clay beds weather to purplish or reddish streaks. Bentonitic clay is common, particularly in the beds immediately above the basal sandstone. The swelling of this clay during weathering causes the characteristic hummocky, cracked and fissured outcrops of parts of unit B. This characteristic of unit B contrasts with the characteris tics of clays in unit A which do not swell during weathering. The aspect of the somber shale and sandstone of unit B is similar to that of the lower part of the Nacimiento formation in the southern and southeastern parts of the area. Unit $B$ is persistent across most of the southern and eastern parts of the area but it varies in thickness because of an 
erosional surface at the top of the unit.

In the section measured by Dane (1936, p. 116) just south of the present area in the SE $1 / 4 \mathrm{sec} .7$, T. 19 N., R. 2 W. (see Fig. 3) beds correlated with unit B are 143 feet thick, and are overlain unconformably by coarse sandstone of the Ojo Alamo. In a composite section measured on the outlying butte in the SW $1 / 4 \mathrm{sec} .25$, and on the topographic spur in the NW $1 / 4 \mathrm{sec} .25$ and NE 1/4 sec. 26, T. 20 N., R. 2 W., unit B is about 125 feet thick. The basal sandstone, about 20 feet thick, consists of fine-to coarse-grained, pebble-bearing, cross bedded sandstone containing silicified wood. The lower part of the sandstone is resistant. Above this, unit B consists of soft white sandstone, and dark-gray to olive-gray bentonitic shale with some soft sandstone interbedded. Unit B is overlain with slight erosional unconformity by hard, ledge-forming sandstone of unit C.

East of the Rio Puerco in the NW part of T. 20 N., R. 1 W. and the SE part of T. 21 N., R. 1 W. the lithology of unit B is similar to that described above. The thickness ranges from 63 feet in the NW $1 / 4$ sec. 20, T. 20 N., R. 1 W. where it is overlain by unit C, to about 130 feet in the NE $1 / 4$ sec. 8 and NW 1/4 sec. 9, T. 20 N., R. 1 W., and about 85 feet in the NE $1 / 4 \mathrm{sec} .22, T .21 \mathrm{~N} ., \mathrm{R} .1 \mathrm{~W}$. where it is overlain by the Ojo Alamo sandstone. The basal sandstone ranges from about 12 feet thick to neariy 30 feet thidk, and ranges from fine-grained to very coarse grained. Here, and in the San Pedro Foothills, most 
of the underlying unit A seems to be misssing, probably because of removal by erosion prior to deposition of unit B.

In the San Pedro Foothills the undivided Fruitland formation and Kirtland shale are discontinuously exposed, but unit B seems to be continuously distributed. Its thickness ranges from about 98 feet near the center of sec. 11, T. 21 N., R. 1 W. to about 188 feet in the SW $1 / 4$ SE $1 / 4 \mathrm{sec} .34, T .23 \mathrm{~N},, \mathrm{R} .1 \mathrm{~W}$. Unit B is overlain by the Ojo Alamo sandstone here and in the Northern Hogback Belt.

In the Northern Hogback Belt, unit B is relatively thin as far north as the southern part of T, $24 \mathrm{~N},, \mathrm{R}, 1 \mathrm{E}$. In exposures on the abandoned Gallina highway near the center of sec. 22, T. 23 N., R. 1 W. unit B rests on rocks assigned to unit $\mathrm{A}$. The basal sandstone of unit $\mathrm{B}$ is tentatively identified as the cross-bedded sandstone about 43 feet thick, and about 95 feet above the top of the Lewis shale. Above this is olivegreen to olive-gray shale about 31 feet thick, overlain by poorly exposed sandstone more than 3 feet thick. The upper part of unit B is concealed, as is the Ojo Alamo sandstone which is believed to overlie the Fruitland and Kirtland. Mr. R. L. Reed reports that a water well penetrated coarse, conglomeratic sandstone about where the Ojo Alamo should be expected in the valley southwest of the exposures of the Fruitland and Kirtland. Poor exposures of soft coarse sandstone assigned to the Ojo Alamo were observed at the edge of a small alluviated valley north of here. 
In the $\mathrm{NE} 1 / 4 \mathrm{sec} .15, \mathrm{SE} 1 / 4 \mathrm{sec} .10$, and $\mathrm{SW} 1 / 4 \mathrm{sec}$, 1

T. 23 N., R. 1 W. the basal sandstone of unit B forms a strong nearly vertical hogback or rib rising above the valley. This sandstore is white and is composed of cross-bedded, well-cemented, fine-to coarse-grained sand containing numerous silicified logs. The basal sandstore of unit B at this locality is strikingly similar to the basal sandstone in sec. 25 , T. 20 N., R. 1 W. The sandstone is apparently a stream-channel deposit, being thickest (about 40 feet) in the SW 1/4 sec. 11, and resting unconfo rmably on a thin remnant of unit A. This sandstone probably is the unit assigned to the Ojo Alamo by Dane (1946, stratigraphic section 2); however, the present writer found that the sandstone is overlain by gray shale and interbedded sandstone similar to the upper part of unit B farther south. On the lower slope of the hill west of the rib, soft coarse-grained, conglomeratic sandstone assigned by the present writer to the Ojo Alamo is exposed poorly.

The Fruitland and Kirtland and the overlying Ojo Alamo sandstone are well exposed along the ridge in sec. $2, T .23$ N., R. 1 W. In the NE $1 / 4$ of this section unit $B$ is a little more than 60 feet thick. The basal sandstone forms a low ridge of fine-to coarse-grained sandstone about 9 feet thick. This is overlain by light- to dark-gray and olive-green, silty clay shale and bentonitic shale containing lenticular sandstone, all about 42 feet thick. This is overlain by mediumto coarse-grained, ledge-forming sandstone containing lenses of pebble 
conglomerate at the base. This conglome ratic sandstone, about 94 jeet thick, is assigned to the Ojo Alamo. To the north in sec. $36, T .24$ N., R. $1 \mathrm{~W}$. near the south end of the long ridge north of Almagre Arroyo, the Fruitland-Kirtland and Ojo Alamo sequence are similar to that described above.

At exposures in the SE $1 / 4 \mathrm{NE} 1 / 4$ sec. $30, T .24 \mathrm{~N} ., \mathrm{R}, 1 \mathrm{E}$. near the Northcutt Ranch, the basal sandstone of unit B is tentatively identified as a hard, brown-weathe ring sandstone 3 feet thick, which seems to rest unconformably on the softer marine sandstone of unit A. The beds overlying the hard sandstone are poorly exposed dark-gray sandy clay shale about 30 feet thick. These beds are overlain by poorly exposed pebble-bearing sandstone of the Ojo Alamo.

On the ridge in secs. 20 and 17, T. 24 N., R. 1 E. a poorly exposed pebble-bearing, coarse-grained sandstone containing silicified wood is probably the basal sandstone of unit B. In the center of sec. 20 this sandstone seems to be resting on fine-to medium-grained soft marine sandstone of unit $\mathrm{A}$, but exposures are too poor to be certain. To the north, in sec. 17, unit A thickens and the basal sandstone of unit B rests on shale and interbedded sandstone of the upper part of unit A. It is possible that the sandstone here called the basal sandstone of unit B is a part of the Ojo Alamo, but the basal sandstone is overlain by gray sandy shale, in turn overlain by a thick soft sandstone which crops out sporadically, and is assigned to the Ojo Alamo. The outcrops are too 
poor and too discontinuous to be certain, but the relations as described seem to be correct.

Near the center of sec. 8, T, 24 N., R, 1 E. the basal sandstone of unit B seems to be a ledge-forming, light yellowish gray, medium-grained sandstone about 74 feet thick, and containing silicified wood. The upper part of this sandstone is poorly exposed and overlying beds are concealed at the point of measurement. However, the area immediately west of this sandstone is a low, rounded hill which probably is held up by the Ojo Alamo sandstone. The exposed sandstone assigned to unit B seems to correlate with a westward-thinning sandstone beneath the Ojo Alamo in the subsurface farther west (Fig. 6).

On the ridges between Arroyo Blanco and Canyoncito de las Yeguas, the undivided Fruitland formation and Kirtland shale are exposed better than to the south, but the outcrops are discontinuous. In sec, 5, T. 24 N., R. 1 E. rocks equivalent to the Pictured Cliffs sandstone and unit A are well exposed. Here the upper marine sandstone of unit A seems to be overlain directly by fine-to coarse-grained, ledge-forming sandstone containing silicified wood. These combined sandstone beds are about 100 feet thick, and no sharp lithologic contact was observed between the lower part, which is fine-to medium-grained, and the upper part which contains coarse grains and silicified wood. It is possible that the upper part is the basal sandstone of unit B, and that the contact with the underlying sandstone of unit $A$ is obscured because of 
reworking. This postulated relationship would be similar to that which can be observed in outcrops in sec. 17, T. 25 N., R, 1 E., anc which was described in the discussion of unit A (p. 65). The sandstone which contains silicified wood is overlain by poorly exposed olive-green and dark-gray shale assigned also to unit $B$. Low sandy hills west of this shale are probably underlain by the Ojo Alamo sandstone. Exposures are quite similar in the NW $1 / 4 \mathrm{sec}, 32, T, 25 \mathrm{~N} ., \mathrm{R}, 1 \mathrm{E}$. Here the upper, ledge-forming part of a sandstone, on which an Indian ruin is situated, is believed to be the basal sandstone of unit B. Softer, finegrained sandstone below the resistant sandstone is probably part of unit A.

In the NW $1 / 4$ sec. $29, T, 25$ N., R. $1 \mathrm{E}$. the basal sandstone of unit B forms a ledge about 20 feet thick consisting of light-tan, fineto coarse-grained sandstone. The upper part of this sandstone is concealed as are the overlying 50 feet of beds. West of this is a low sandy hill probably underlain by the Ojo Alamo sandstone. The sequence in the NE $1 / 4 \mathrm{sec} .17$, T. $25 \mathrm{~N} ., \mathrm{R} .1 \mathrm{E}$. is similar. Here the basal sandstone of unit B contains silicified wood, is about 14 feet thick, and forms a strong ledge above shale of the upper part of unit A. Dane (1946) tentatively correlated this sandstone with the Ojo Alamo. Northward, beds of the upper part of unit $A$ thicken and, with the overlying basal sandstone of unit B, form a massive ledge 60-100 feet thick. 
These rocks were assigned to the Animas formation by Dane (1946). stratigraphic section 8). In the SE $1 / 4 \mathrm{SE} 1 / 4$ sec. B, T, $25 \mathrm{~N},, \mathrm{R}, 1 \mathrm{~B}$. the basal sandstone of unit B is overlain by poorly exposed gray and olive-green shale estimated to be about 100 feet thick. These beds are believed to be the upper part of unit $B$, and are overlain by a ledgeforming, thick, coarse-grained, pebble-bearing sandstone correlated with the Ojo Alamo.

Near the center of sec. $4, T, 25$ N., R. 1 E, the upper shale of unit $B$ is cut out by a slightly angular erosional unconformity, and the Ojo Alamo sandstone rests on the combined sandstones of unit B and unit $A$ from here to the northern edge of the area. Locally, as in the SW $1 / 4$ sec. 21 , thin remnants of the upper shale of unit B intervene between the sandstones of the Fruitland-Kirtland and the Ojo Alamo, and facilitate the mapping of a contact between the sandstones. Elsewhere the contact is drawn at a topographic notch 60-100 feet above the base of the Fruitland-Kirtland sandstone beds. This contact is only approximate at most places. 
Unit C

Resting on unit B in the southeastern part of the area is anit consisting of thick, ledge-forming, fine-to coarae-grained alsdstone beds with some intercalated slope-forming beds of dark-gray, olivegreen, and purplish shale and fine-grained sandstone. These rocks, here called informally unit $\mathrm{C}$ of the undivided Fruitland formation and Kirtland shale, are similar to the overlying Ojo Alamo sandatone. However, the rocks of unit $C$ are separated from overlying and underlying rocks by erosional unconformities.

In the NE $1 / 4 \mathrm{sec}, 26, T .20 \mathrm{~N} .$, R. 2 W. the sandstone and interbedded shale of unit C are well exposed on an eastward-projecting spur of Mesa Portal (Fig. 3). The sandstone beds hold up two prominent topographic benches separated by slope-forming shale and are similar to the overlying Ojo Alamo sandstone which caps Mesa Portal. On the spur the sandstone and interbedded shale of unit $C$ are about 90 feet thick. Southward along the east side of Mesa Portal the two sandstones of unit C merge to form a massive, cliff-forming unit almost 100 feet thick at places in the escarpment of the mesa. Although the sandstones of unit C are persistent for considerable distances their thickness is erratic, and locally they grade laterally into shale. In places the sandstone of unit $C$ is overlain by shale, in turn overlain unconformably by the persistent Ojo Alamo sandstone which is 50-100 feet thick and which caps Mesa Portal. At several places on the east 
face of Mesa Portal--notably in the NE 1/4 NW 1/4 sec, 35, T. 20 N., R. 2 W. - - the Ojo Alamo sandstone thickens abruptly, and the ercsion surface at its base cuts out the shale at the top of unit $C$, and also cuts out most of the thick sandstone of unit C. Neax the southeastern edge of Mesa Portal (south of the present area) the sandstones of unit C wedge out laterally into shale and, at the end of the mesa the Ojo Alame rests on shale equivalent to the sandstones of unit $C$.

North and northeast of Mesa Portal, on both sides of the Rio Puerco, sandstone beds of unit $\mathrm{C}$ hold up topographic benches below the Ojo Alamo. In the NW $1 / 4$ sec. $20, T, 20 \mathrm{~N} ., \mathrm{R}, 1 \mathrm{~W}$. unit $\mathrm{C}$ is about 120 feet thick. The lower sandstone is about 40 feet thick but its thickness varies considerably along the outcrop because it rests on a channeled erosion surface at the top of unit B. The medial shale and soft sandstone of unit $C$ are almost 55 feet thick. The upper sandstone is about 25 feet thick and locally forms a ledge beneath the Ojo Alamo. The thickness of the upper sandstone varies considerably because it locally grades laterally into shale. At places this sandstone is overlain by olive-gray shale, but at other places the shale is cut out by an erosional surface at the base of the Ojo Alamo. Unit C appears to have been truncated by the Ojo Alamo sandstone in the eastern part of sec. 8 , T. 20 N., R. 1 W. where the total thickness of the undivided Kirtland shale and Fruitland formation is about 126 feet in contrast to a thickness 
of 246 feet west of the Rio Puerco.

The beds of unit $C$ are not known to occur at the surface in the eastern part of the area except at the above-described localities. The sandstone beds in the upper part of the Fruitland and Kirtland in the SW part of T. 20 N., R. 5 W. are probably equivalent to unit C. The se rocks are absent locally to the east. It is possible that unit $C$ is actually equivalent to the rocks in the Northern Hogback Belt that were correlated with unit $B$, but subsurface data seem to indicate that the rocks equivalent to unit $C$ are not present at the surface in the Northern Hogback Belt.

Subsurface Correlations

Units A, B, and C of the undivided Fruitland formation and Kirtland shale can be recognized in the subsurface of the area investigated. The units were not designated on the subsurface correlation diagrams, but their approximate positions can be determined by comparing the surface stratigraphic sections in Figure 3 with the equivalent sections on Figures 6 and 7 .

In the subsurface of the southern part of the area, units $A$ and B are represented mainly by shale containing beds of thin siltstone and carbonaceous sandstone and, near the base of unit $A$, a few thin beds of coal or coaly shale. In the central part of the area, in the interval of unit $A$, there are several thin beds of siltstone and shaly fine-grained 
sandstone interbedded in thick shale. The siltstone and sandstone ds persist northward and thicken gradually until, in the northe rn part of the area, the beds pass into fine-grained sandatone, and me rge to form a unit of sandstone 60-80 feet thick. This sandstone correlates with the Halymenites-bearing marine sandstone of unit $A$ exposed at the surface in the Northern Hogback Belt.

Above the sandstone, siltstone, and shale of unit $A$ is anothex similar sequence of thin siltstone and fine-grained sandstone which thickens northward and correlates with the basal sandstone of unit B in the Northern Hogback Belt. This sandstone, locally 60-80 feet thick, is a conspicuous bed below the Ojo Alamo and above the Halymenites-bearing sandstone in logs of wells drilled in the eastern part of the basin in Tps. 23 and 24 N., R. 1 E. and R. 1 W. The sandstone beds of unit B thicken also eastward (Fig. 7).

Sandstone and shale of unit $C$ seem to be fairly persistent in the subsurface across the southern half of the area, and probably correlate with sandstone and shale in the upper part of the undivided Fruitland formation and Kirtland shale (the upper part of the Kirtland shale as mapped by Dane, 1936) in the SW part of T. 20 N., R. 5 W. The sandstone beds of unit $C$ seem to thin to the northeast and north across most of the area, and grade into shaly sandstone and siltstone interbedded in shale. These upper beds of the Fruitland and Kirtland are locally cut out by the Ojo Alamo sandstone, and in the east-central and north- 
eastern part of the area the top of the Fruilland-Kirtland seems to be below the stratigraphic position of unit $C$.

The erosional unconformities between units of the undivided Fruitland formation and Kirtland shale in outcrop areas along the eastern edge of the Central basin are present also in the subsurface along the eastern margin of the basin. This is shown by the uneven thickening and thinning of parts of the Fruitland and Kirtland penetrated by wells. However, in the subsurface of most of the area the units of the Fruitland-Kirtland are nearly parallel. Across the southern part of the area between exposures west of the Rio Puerco and the Hancock No. 1 Brown well in sec. 33, T. 21 N., R. 5 W. units A and B increase in thickness from about 155 feet in the east to about 280 feet in the west. This suggests a slightly angular erosional unconformity at the base of unit C. Evidence of e rosion was observed at the base of this unit at surface exposures in sec. 20, T. 20 N., R. 1 W., and on the eastern side of Mesa Portal.

\section{General Discussion}

The lithology and fossils of the units of the Fruitland formation and Kirtland shale give evidence of the environments in which they were deposited. The sediments of unit $\mathbf{A}$ probably were deposited in a ma rine and brackish-wate $r$ environment as indicated by their fine-grained, even-bedded nature, and by their content of coaly material and 
marine fossils. The "Lewis shaie" norule and faunule of Andersun (1960, p. 8) was collected from rocks in the NE $1 / 4$ sec. $4, \Upsilon$. $25 \mathrm{~N}$, R. 1 E. which the present writer assigns to the middle part of unit A of the Fruitland and Kirtland. On the basis of contained spores, pollen. foraminifers, dinoflagellates, and hystrichosperids, Anderson concluded that the sediments were deposited in brackish water. Halymenites, which is common in the sandstones of unit $A$, is of uncertain affinities, but in the San Juan Basin it seems to occur only in marine rocks. The marine pelecypod Inoceramus sp. also occurs at places in these sandstones.

The basal sandstone of unit $B$ in outcrop areas has the general lithologic characteristics of stream-channel deposits and contains abundant fossil wood indicating a terrestrial environment of deposition. The carbonaceous bentonitic shale and fine-grained sandstone of the upper part of unit B indicate deposition in still water in swampy or lacustrine environments. The Kirtland shale florule of Anderson (1960, p. 5) was collected in the east-central part of sec. $8, T, 20$ N., R. 1 W. from rocks assigned to unit $B$. The florule is said to be spores and pollen of vegetation of the immediate area deposited in a swampy envir onment.

The rocks of unit $C$ exposed at the surface also seem to have been deposited in stream-channel and floodplain environments. Sandstone beds of the undivided Fruitland formation and Kirtland shale range in grain size from very fine to very coarse, and contain small 
pebbles at places. Some of the fine-to medium-grained sand is wellrounded grains of quartz probably derived from the source areas to the southwest which supplied the sediment of older Cretaceous rocks. However, much of this sand could have been derived also from erosion and reworking of oldex Cretaceous rocks.

The lithology of many of the sandstone beds of the FruitlandKirtland is dissimilar to the lithology of the underlying Pictured Cliffs sandstone and the Mesaverde group, and indicates source terranes different from those of most of the older Cretaceous rocks. Much of the sand of the Fruitland and Kirtland is composed of coarse-grained to granule-size, angular to subangular quartz, pink and green chert and rock fragments, and pink and white feldspar fragments. Pebbles consisting of quartz, quartzite, chert, and volcanic rock are present at places. The stratigraphically highest rocks of the Colorado Plateau Legion from which materials of this type could have been derived are those of the Dakota sandstone of $\operatorname{Early}(?)$ and Late Cretaceous age. Rocks of the Morrison formation (Jurassic) also contain material of this type. The feldspar fragments in the Fruitland-Kirtland sandstones do not necessarily indicate a source terrane of Precambrian granitic rocks, inasmuch as arkosic rocks occur in the Chinle formation (Triassic), the Cutler formation and equivalent rocks (Permian), and the Magdalena group and equivalent rocks (Pennsylvanian) in uplifts bounding the San Juan Basin. 
The Halymenites-bearing marine sandstone of urit $A$ is composed mainly of fine- to medium-grained sand but contains a few beds of coarsegrained sand. This sand also contains biotite and other ferromagnesian minerals and is slightly different from the Pictured Cliffs sandstone.

The bentonitic clay shale of the Fruitland-Kirtland is considerably different from the shale of underlying Cretaceous formations. The bentonitic shale probably is altered volcanic ash. To generalize, sediments of the Fruitland-Kirtland sequence reflect tectonic changes in the San Juan Basin and adjacent regions and are the oldest dixect evidence of Laramide disturbances in this region.

The changes in thickness and grain size of the rocks of the Fruitland and Kirtland give evidence of the direction of source areas of sediments of the units. As previously discussed, the Pictured Cliffs sandstone of the present area was deposited probably as near-shore and neritic sediments derived from regions south of the present area of investigation. Dane (1946) has shown that the Pictured Cliffs sandstone of the northern part of the San Juan Basin thins and wedges out southward north of the present area, indicating that late in Pictured Cliffs time a part of the Cretaceous sea was restricted into an embayment (Fig. 10) in the eastern part of the Colorado Plateau. The sediments of unit A in the southeastern part of the area are shale containing coaly beds and thin sandstone deposited in a brackish environment at the southern edge 
of the embayment of the Cretaceous sea. Similar rocks of ate Fruitland formation were deposited on the northern edge of the embay nent (Zapp, 1949; Wood, Kelley, and MacAlpin, 1948; Dane, 1946). Dusing deposition of these rocks the region of the Central basin must have subsided and the marine waters deepened and spread laterally. The area of the Nacimiento uplift may have been a shoal area on which sediments of unit $\mathbf{A}$ were very thin. The Halymenites-bearing marine sandstone of unit A thickens and coarsens northward, and its sediments were derived probably from a highland rising north of the marine embayment in the vicinity of the present San Juan Mountains.

After the deposition of unit A, slight folding occurred on the eastern margin of the San Juan Basin, and rocks of unit A were slightly eroded on the edge of the basin. Terrestrial deposits of unit $B$ then were laid down on unit $\mathbf{A}$. The sandstones of unit $\mathbf{B}$ grade laterally into thin persistent beds of shaly sandstone and siltstone enclosed in thick shale in the subsurface of the southwestern part of the area. This gradation takes place both westward and southward, indicating that source areas of these sediments were east and northeast of the present San Juan Basin. The distal (western) parts of the sandstones of unit B are so fine-grained and persistent in the subsurface that they appear to have been deposited in a marine or lacustrine environment. Possibly this environment was a remnant of the former embayment of the Cretaceous sea isolated (or nearly isolated) from the eastward- 
retreating sea by the rise of highlands east of the present area. Unit C, present in the southern part of the area, seems to rest with slight unconformity on unit B, indicating that further slight folding and uplift took place along the eastern edge of the basin after deposition of unit B. The basin may have been tilted slightly to the west at this time as was postulated by Silver (1950, p. 112, 119-121, and figs, 3 and 7). The sandstones of unit C also thin and become finer grained in the subaurface away from outcrops in the southeastern and southern part of the area. This indicates that source areas for sediments of unit $C$ were south and southeast of the present area. Because rocks equivalent to unit $C$ seem to have been eroded from the eastern part of the area prior to deposition of the Ojo Alamo sandstone, it is not known whether the source areas of earlier Fruitland and Kirtland sediments east and northeast of the basin were contributing sediment at the time of deposition of unit C. Presumably they were. Facies relations on the western side of the San Juan Basin indicate that Fruitland and Kirtland sediments of that region were derived from the southwest and west.

\section{Contacts}

The undivided Fruitland formation and Kirtland shale rest conformably on the Pictured Cliffs sandstone in most of the area. The carbonaceous sandy shale of unit A seems to be gradational into the Pictured Cliffs, although the contact is fairly well defined. Locally 
in the San Pedro Foothills the basal sandstone of unit B cuts out all of anit $A$ and rests on rocks equivalent to the Pictured Cliffs with slight erosional unconformity.

The contact of the undivided Fruitland formation and Kirtland shale with the overlying Ojo Alamo sandstone is unconformable. At all localities where the contact was observed it is erosional.

\section{Age and Correlation}

Other than unidentified fossil wood, the only fossils found by the writer in the undivided Fruitland formation and Kirtland shale in the present area are Halymenites (a fossil which may be a marine fucoid alga, or a fossil bur row of a marine organism), and Inoceramus sp., a marine pelecypod. Both of these forms indicate Cretaceous age. Vertebrate, invertebrate, and plant fossils were collected from the Fruitland formation and Kirtland shale in the southwestern and western parts of the Central basin by several workers. Gilmore (1916, p. 279-281) discussed the vertebrate fossils which include remains of dinosaurs, turtles, crocodiles, and fish, and concluded that the Fruitland and Kirtland (and the Ojo Alamo) are older than the latest Cretaceous rocks (Lance formation) of Wyoming and Montana. Stanton (1916, p. 309-310) discussed nonmarine Cretaceous invertebrates from the Fruitland formation. He concluded that both brackish-water and freshwater forms occur, and that the Fruitland formation is older than the 
Lance formation. In a discussion of the flora of the Fruitland and Kirtland, Knowlton (1916, p. 329-331) concluded that the Fruitland and Kirtland are of Montana age. Reeside (1924, p. 24) sumamarized the evidence provided by fossils and concluded that the Fruitland formation and Kirtland shale contain closely related floras and faunas, and that both are of late Montana age, possibly equivalent to part of the Pierre shale and part of the Fox Hills sandstone of the region east of. the Rocky Mountains. The Fruitland and Kirtland, then, are to be considered as being of Late, but not latest, Cretaceous age.

The units of the Fruitland-Kirtland sequence of the present area cannot be correlated with certainty with units of the Fruitland and Kirtland on the western side of the Central basin. The carbonaceous shale and sandstone of unit $\mathrm{A}$ are almost certainly equivalent to part of the Fruitland formation which is $250-530$ feet thick in the northwestern part of the Central basin (Reeside, 1924, p. 20; Barnes, Baltz, and Hayes, 1954). Unit B may be equivalent also to part of the Fruitland, or it may be equivalent to the lower member of the Kirtland shale as would seem to be indicated by comparison with Dane's (1936, p. 113-116) description of the Kirtland of the southern part of the Central basin. The sandstone beds of unit $B$ in the present area grade westward in the subsurface into rocks which may be marine. Dilworth (1960, p. 25) reported foraminifera occurring near the middle of the Farmington sandstone member of the Kirtland shale, possibly indicating that the 
lower member of the Kirtland shale and part of the Farmington sandstone are of marine, or at least brackish-water, origin on the western side of the Central basin. Unit $\mathrm{C}$ is very similar to beds of the Fasaring ton sandstone member of the Kirtland shale. It is possible also that unit $\mathrm{C}$ is equivalent to the lower shale and lower thin conglome ratic sandstone assigned to the "typical" Ojo Alamo on Ojo Alamo and Barrel Spring Arroyos by Bauer (1916, p. 276).

The bentonitic shale beds in units $B$ and $C$ are probably altered volcanic ash and this suggests a correlation with volcanic rocks of the McDermott member of the Animas formation (Barnes, Baltz, and Hayes, 1954; see also Reeside, 1924, p. 24-28). However, the writer and R. B. O'Sullivan found cobbles of andesitic rock in the Farmington sandstone member of the Kirtland shale northwest of Farmington; thus, the presence of volcanic material does not automatically indicate equivalence to the McDermott which lies above the Kirtland shale. Also, the presence of siliceous pebbles in units $B$ and $C$ does not necessarily indicate equivalence to pebble-bearing rocks of the McDermott (see Reeside, 1924, p. 26), inasmuch as siliceous pebbles occur also in sandstone included in the upper part of the Kirtland by Barnes, Baltz, and Hayes (1954), and in sandstones included in the upper part of the Kirtland by Reeside (1924, pl. 1) west of Pinyon Mesa northwe st of Farmington.

The southward-thinning marine sandstone of unit $A$ is probably the subsurface unit called the "northeast lobe" of the Pictured Cliffs 
by Silver (1950, p. 112). On the basis of reconnaissance examination of rocks of the northeastern and northern parts of the San Juan Basin, the present writer believes that the marine sandstone of unit $A$ is equivalent to sandstone beds in the upper part of the Fruitland formation or in the Kirtland shale of the northern part of the basin. Thus, the marine sandstone of unit A probably is youngex than the northern part of the Pictured Cliffs which is probably about the same age as the Pictured Cliffs in the present area.

Shale and fine- to coarse-grained, even-bedded sandstone assigned by Wood, Kelley, and MacAlpin (1948) to the Kirtland and lower part of the Animas formation ("zone of intertonguing between Kirtland and Animas") southwest of Pagosa Springs, Colorado, are probably a near-shore facies of the marine rocks of unit A. R. B. O'Sullivan and the writer found petroliferous fossiliferous limestone in these rocks south of Pagosa Springs.

\section{Tertiary(?) Rocks}

Ojo Alamo Sandstone

$\underline{\text { Definition }}$

Above the undivided Fruitland formation and Kirtland shale is a thick, persistent, fine-to coarse-grained, locally conglome ratic sandstone of varied thickeness. This sandstone was first mapped as the lower part of the Puerco formation by Gardner (1909, pl. 1; 1910, 
p1. 2). Renick (1931, p. 52) also mapped the thick sandstone Iyin on the Fruitland and Kirtland (part of which he included with the Lewis shale) as the lower part of the Puerco formation.

Dane (1936, p. 117) found that the sandstone mapped as the lower part of the "Puerco formation" by Gardner and by Renick could be traced southwestward into beds named the Ojo Alamo sandstone by Bauer (1916, p. 275-276). The type locality of the Ojo Alamo sandstone is on Ojo Alamo Arroyo in the NW part of T. 24 N., R. 11 W. in the southwestern part of the Central basin near Ojo Alamo store. Here the Ojo Alamo sandstone is said by Bauer $(1916$, p. 276) to consist of an upper conglomerate, 25 feet thick, resting on a medial unit consisting of wine-red and bluish-gray banded shale interbedded with lenses of gray-white, soft sandstone, all about 34 feet thick. The medial shale rests on a basal unit of poorly consolidated pebble conglomerate 9 feet thick. According to Bauer the medial shale unit pinches out laterally, and the upper conglomerate rests on the lower conglomerate. At the type locality the Ojo Alamo sandstone is overlain by rocks forme rly classed as the Puerco formation (the Nacimiento formation in present terminology) and is underlain by beds called the Kirtland shale by Bauer, and the "McDermott formation" by Reeside (1924, p. 28). Reeside (1924, p. 26) showed that beds he correlated with the McDermott formation (the McDermott member of the Animas formation of Barnes, Baltz, 
and Hayes, 1954) pinch out east of the type locality, and the Ojo Alamo Fats on the upper part of the Kirtland shale in most of tl southern part of the Central basin.

The Ojo Alamo sandstone of the present repozt is mapped generally the same in the southern part of the present area as the Ojo Alamo of Dane (1936, p. 116-121, and pl. 39), although locally the iower boundary is not the same. Dane $(1946)$ indicared that the Ojo Alamo is present on the eastern side of the San Juan Basin as far north as T. 25 N., R. 1 E. The rocks mapped as Ojo Alamo in the Northern Hogback Belt by the present writer are not the same as those assigned to the Ojo Alamo by Dane (1946) as is explained below.

Extent and Thickness

The Ojo Alamo crops out in an irregular band above the undivided Fruitland formation and Kirtland shale almost continuously across the southern tier of townships (T. 20 N., R. 1-5 W.) of the present area of investigation where it caps northward-sloping cuestas. The rocks dip in northe rly directions and the Ojo Alamo forms steep cliffs facing south, southeast, and southwest. According to Dane (1936, p. 121) the thickness of the Ojo Alamo is about 170 feet just west of San Ysidro Wash (Arroyo San Ysidro on Figure 2 of this report). In a composite section measured in the NW $1 / 4 \mathrm{NE} 1 / 4 \mathrm{sec} .23, \mathrm{~T} .20 \mathrm{~N} ., \mathrm{R} .2 \mathrm{~W}$. the Ojo Alamo is 70 to 80 feet thick (excluding the sandstones of unit C of the 
5 ruitland and Kirtland that were mapped with the Ojo. Alamo at this place by Dane, 1936). East of the Rio Puerco, the Ojo Alamo trikes northeast and forms northwest-sloping cuestas. In the SE $1 / 4 \mathrm{NE} 1 / 4$ of sec. 8, T. 20 N., R. 1 W. the Ojo Alamo is a little more than 60 feet thick, and in the S $1 / 2 \mathrm{NE} 1 / 4 \mathrm{sec} .22, T .21 \mathrm{~N} ., \mathrm{R}, 1 \mathrm{~W}$, the Ojo Alamo is 91 feet thick.

In the San Pedro Foothills the Ojo Alamo sandstone dips steeply west, and in places it is vertical or slightly overturned. Here the Ojo Alamo forms low, rounded ridges exposed in the walls of the canyons which drain San Pedro Mountain. In the SE $1 / 4 \mathrm{SW} 1 / 4 \mathrm{sec}$. 11, T. 21 N., R. I W., the Ojo Alamo is 113 feet thick. The Ojo Alamo is well exposed along an abandoned irrigation ditch on the north side of San Jose Creek in the SW $1 / 4$ NE 1/4 sec. 34, T. 23 N., R. 1 W. where it is about 90 feet thick.

In the Northern Hogback Belt the Ojo Alamo is soft and poorly exposed or covered at many places, but there are a sufficient number of outcrops to establish its identity and persistence in this region. In secs. 10 and 15, T. 23 N., R. 1 W. the pebble-bearing Ojo Alamo is poorly exposed on the slopes west of the high rib of the basal sandstone of unit B of the Fruitland and Kirtland. The Ojo Alamo forms low, northwestdipping ridges of conglome ratic sandstone in the northeastern part of T. 23 N., R. 1 W. and near the southeastern corner of T. 24 N., R. 1 W. In the NE $1 / 4 \mathrm{sec}, 2, \mathrm{~T} .23 \mathrm{~N} ., \mathrm{R} .1 \mathrm{~W}$. the Ojo Alamo is about 
110 feet thick. Near this locality a thin sandstone correlated by Dane (1946, stratigraphic section 3) with the Ojo Alamo is believed by the present writer to be equivalent to the coarse-grained sandstone at the base of unit B of the undivided Fruitland formation and Kirtland shale.

In sec. $30, T, 24$ N., R. 1 E. the Ojo Alamo forms a poorly exposed low ridge of pebble-bearing sandstone just east of the Northcutt Ranch. In the SE $1 / 4$ sec, $20, T .24$ N., R. 1 E. the Ojo Alamo is tentatively identified as a poorly exposed yellowish sandstone lying just west of the ranch road. A light-gray sandstone containing silicified wood on the low ridge just east of the road is correlated with the basal sandstone of unit B of the Fruitland-Kirtland. North of here in sec. 17 the Ojo Alamo forms a low ridge and rests on dark-gray and black shale ssigned to the upper part of unit B. The basal sandstone of unit B containing fossil wood and a few small pebbles occurs on the wooded. ridge east of the Ojo Alamo. Northward from here to the northern part of T. $25 \mathrm{~N} .$, R. $1 \mathrm{E}$. , the Ojo Alamo is very poorly exposed but crops out at places where it forms low hills largely masked by sandy soil. Along the Forest Service road in the SE $1 / 4 \mathrm{sec} .8, T .25 \mathrm{~N}$. , R. I E. thick sandstone correlated with the Ojo Alamo rests on dark gray and olive shale of the upper part of unit B of the Fruitland and Kirtlada. The sandstone in the NE $1 / 4 \mathrm{sec} .17, T, 25 \mathrm{~N},, \mathrm{R}, 1 \mathrm{E}$. that Dane (1946, stratigraphic section 8) specifies as being about 100 feet above the base of the Anima formation and correlates doubtfully 
with the Ojo Alamo is correlated with the basal sandstone of uxit B of the Fruitland-Kirtland by the present writer. Northward from bere the Ojo Alamo is more resistant to erosion and forms westward-sioping ridges. It caps a high cuesta in T. 26 N., R. 1 E. where it rests directly on sandstone of the Fruitland and Kirtland. In the SW $1 / 4 \mathrm{SE} 1 / 4$ sec. 33, T. 26 N., R. 1 E. the Ojo Alamo is nearly 200 feet thick and rests unconformably on sandstone, about 53 feet thick, of unit B of the Fruitland and Kirtland. These combined sandstones were classified as the basal sandstone of the Animas formation by Dane (1946 and 1948). The Ojo Alamo caps the high cuestas from here to the northern edge of the area and rests on sandstone of the Fruitland and Kirtland from which it can be differentiated with certainty at only a few places.

In the subsurface the Ojo Alamo is distributed continuously throughout the area. In the southern part of the area the Ojo Alamo ranges in thickness from 80 to 100 feet, and thickens gradually to the north or northeast as it does at the surface. The thickening takes place as sandstone tongues in the lower part of the Nacimiento formation thicken northward and merge with the underlying Ojo Alamo sandstone (Figs. 5 and 6). In the northern part of the area the Ojo Alamo ranges in thickness from about 180 feet to about 200 feet.

\section{$\underline{\text { Lithology }}$}

The Ojo Alamo sandstone is composed of several beds of buff, 
tan, and brown, medium-grained to very coarse grained sandstone that contain thin lenses of olive-green to gray shaile at places. The sand is mostly angular to subangular and consists mostly of quartz. Other common constituents are sand grains and granules of red, gray, and green chert and other rock fragments. Sand and granule-size cleavage fragments of pink feldspar are common also. Pebbles ranging in size from one-half inch to several inches in diameter are scattered through the sandstone at places and, locally, the lower few inches to several feet of the formation is pebble to cobble conglomerate. Most of the pebbles and cobbles are well-rounded, gray and white quartz and quartzite, but red, yellow and green siliceous pebbles, and sandstone and shale pebbles also are present. Some of the pebbles contain marine fossils and appear to be siliceous replacements of pebbles that were formexly limestone. In sec. 36, T. 24 N., R. 1 W. the Ojo Alamo contains numerous 2 - to 3 -inch pebbles of volcanic rock including a distinctive pink rhyolite porphyry. Logs replaced by silica, or by limonite, are common in the Ojo Alamo at many localities. Some of the logs are as much $Z 1 / 2$ feet in diameter, and 20 feet or more in length. These art amilar to smaller silicified logs found in sandstone of the Fruitland And Kintand:

In outcrops the Ojo Alamo sandstone is moderately indurated semexted by silica, clay, and ferruginous compounds. Some hard, 
thin beds are highly ferruginous and rusty weathering. However, at places it was found that the sandetore several inches beneath the weathered surface is much more friable than it is at the surface. It is possible that the Ojo Alamo is indurated better at the surface than where it is buried beneath younger rocks because mineral-bearing water "bleeds" out of the sandstone, evaporates at and near the surface of the sandstone, and deposits mineral matter between the grains.

Tangential cross bedding characterizes the formation, but at most places the several beds of sandstone tend to weather as massive units. In the southern part of the area, the lower half, approximately, of the Ojo Alamo forms a massive cliff. The upper half is more highly cross bedded and less resistant, and forms rounded slopes and ledges set back from the cliffs of the lower half.

The sandstone and conglome rate of the Ojo Alamo are mainly overlapping stream channel deposits. Silver $(1950$, p. 121) postulated that the Ojo Alamo was deposited as pediment gravel. Some of the upper beds of the Ojo Alamo show the bedding characteristic of dune sand. Sinclair and Granger (1914, p. 301) suggested that the "upper conglomeratic sandstone" of the rocks later called the Ojo Alamo by Bauer "... seems to represent material swept into the basin of accumulation by floods, perhaps during an interval of crustal uplift which stimulated 
the streams to carry down the gravels which had accumulated in their channels and to undermine their banks, destroying the largetrees grow ing there. Some of the drift logs are two or three feet across and over 50 feet long. The branches and bark have been stripped off . . ."

The sandstone of the Ojo Alamo is similar to the coarse-grained sandstone in parts of the Fruitland and Kirtland. Generally, the Ojo Alamo is much thicker and coarser grained and more arkosic, and its contained pebbles are larger than those found at places in the Fruitland and Kirtland.

The lithologies of the Ojo Alamo and the coarse sandstone of the Fruitland and Kirtland are similar enough to suggest common source areas. The Ojo Alamo sandstone thickens northward suggesting that a major source area was a highland in the position of part of the present an Juan Mountains. The coarsest gravel observed in the Ojo Alamo in the present area is in the northeastern part of T. $23 \mathrm{~N} ., \mathrm{R} .1 \mathrm{~W}$. , the southeastern part of T. 24 N., R. 1 W., and the southwe stern part of T. 24 N., R. $1 \mathrm{E}$. This gravel may have been derived from a source east or northeast of this part of the basin. Possibly this source area was in the vicinity of the present Brazos uplift. Dane (1936, p. 118) observed that in the southern part of the area, the grain size of the Ojo Alamo increases toward the east, evidence also favoring a postulated source area east of the pregent area of investigation. Reeside (1924, 
p. 29-30) suggested that the Ojo Alamo of the western side of the basin was derived from the east or south. However, the writer and R. B. O'Sullivan measured the strikes of nume rous channel edges, and the dips and strikes of foreset beds and laminae in the Ojo Alamo near Farmington and these indicate that in this part of the basin the Ojo Alamo was deposited by streams flowing from the west-northwest and the northwest. Probably the Ojo Alamo was laid down as pediment deposits by streams flowing centripetally into the basin from several sides after downwarping of the basin, or uplift of highlands in the surrounding region.

\section{Contacts}

The Ojo Alamo rests with erosional unconformity on the undid Fruitland formation and Kirtland shale in the present area of investigation. Evidence of scouring and deep channeling at the base of the Ojo Alamo may be observed at many places.

Reeside (1924, p. 26) discussed the contact of the Ojo Alamo with underlying beds on the western side of the Central basin and said that the evidence of an erosional contact and overlapping of older rocks by the Ojo Alamo is clear in that region. However, Dane (1936, p. 118 -121) believed that the erosion surface at the base of sandstone of the Ojo Alatao is no more than the result of scouring and channeling by strearis competent enough to transport and deposit coarse sediment. 
Also, according to Dane (1936, p. 119), at many places in the area between Alamo Arroyo and the Rio Puerco the base of the Ojo Alamo is not the same stratigraphic position at points a few hundred feet apart. He believed that, although there was a sudden change in conditions of deposition when the Ojo Alamo was deposited, the evidence shows that this change did not occur everywhere at the same time, and at places there was a transitional change in sedimentation. Dane $(1936$, p. 120121) suggested that the eastward thinning of the underlying Kirtland shale is the result of a lesser amount of deposition toward the southeast and that there is no hiatus between the Ojo Alamo and the Kirtland shale. However, the present writer believes that the evidence of erosional unconformity and slight angular unconformity is clear in the present area of investigation. The variations of thickness of the undivided Fruitland formation and Kirtland shale in the San Pedro Foothills and Northern Hogback Belt indicate that slight folding and erosion occurred there before deposition of the Ojo Alamo. The lower contact of the persistent sandstone mapped as the Ojo Alamo by the present writer is at a higher stratigraphic position at places than the contact mapped by Dane (1936). In the southeastern part of T. 20 N., R. 2 W. the contact mapped by the present writer is one of strong erosional unconformity, and locally the Ojo Alamo cuts out lenticular sandstone and shale beds of unit C of the Fruitland and Kirtland (mapped with the Ojo Alamo by 
Dane, 1936). These beds of unit C wedge out southward into shale and are absent at the south edge of Mesa Portal south of the area of the present report. However, the sandstone beds of unit $\mathrm{C}$ are present below the Ojo Alamo at places in T. 20 N., R. 5 W. The unconformity at the base of the sandstone mapped as the Ojo Alamo by Dane at most places, but within the sandstone and shale included in the Ojo Alamo by Dane at a few places, probably accounts for the differing stratigraphic positions of the base of his unit in the southern part of the area. This unconformity is difficult to recognize unless individual beds are traced because the lithology of the finer grained parts of the Ojo Alamo is similar to the lithology of sandstone of unit C of the undivided Fruitland and Kirtland. (See Dane, 1936, p. 119). In the subsurface the undivided Fruitland formation and Kirtland shale are as much as 450 feet thick in the western part of the area. In the eastern part of the area these rocks are less than half this thickness. As interpreted from electric logs of wells, individual beds within the Fruitland and Kirtland do not thin eastward as would be expected if the over-all thinning was the result of a lesser amount of deposition to the east. In fact, some beds thicken eastward (Figs. 6 and 7). It appears that, from west to east, successively lower beds of the Fruitland and Kirtland are truncated by the Ojo Alamo in the western part of the area. This would seem to indicate that, prior to deposition of the Ojo Alamo, the rocks of the eastern part of the basin were tilted to the west, and part of the Kirtland was eroded from the eastern part of the basin. This 
view is essentially the same as the conclusion of silver $(1950, p$. Hlit) who reported that the relief on the top of the Kirtland in the Aabsusface of the Gavilan area is 100 to 200 feet in 10 miles, The combined thickness of the Fruitland formation and Kirtland wale on the western side of the Central basin near Farmington is more than 1,600 feet; thus it is possible that as much as 1,400 feet of Fruitland-Kirtland soelca was eroded from the eastern part of the basin prior to deposition of the Ojo Alamo. However, as previously discussed, there is evidence of local uplift and erosion in the eastern part of the basin during deposition of the Fruitland and Kirtland, and the se rocks may never have been as thick as they are on the western side of the Central basin.

The Ojo Alamo sandstone seems to be conformable with the overlying Nacimiento formation in the area. No evidence of unconformity was observed in outcrops, and subsurface data seem to indicate that the Ojo Alamo is conformable with the Nacimiento and intertongues with it. In the vicinity of the type locality of the Ojo Alamo, Brown (1910), Sinclair and Granger (1914, p. 204, and pl. 22), and Bauer (1916, p. 276) report an erosional unconformity at the base of the Puerco formation (in present terminology, the lower part of the Nacimiento formation). Reeside (1924, p. 37) stated that in the western part of the basin the Puerco formation rests on the Ojo Alamo with erosional unconformity, but without discordance of dip. 
Age and Correlation

In the southwestern part of the Central basin neas the type locality numerous dinosaur and other reptilian fossils have been collected from beds assigned to the Fruitland formation, Kirtlasd shale, and the Ojo Alamo sandstone by Bauer (1916). In summarising the evidence of age provided by these fossils, Gilmore (1916, p.281) states:

"...I conclude that the vertebrate remains from the Ojo Alamo, Kirtland, and Fruitland formations show beyond all question that they pertain to a fauna or faunas dis tinctly older than that of the Lance, and that such evidence as there is contributes to the support of Brown's contention that the Ojo Alamo sandstone is synchronous with the Judith River and Belly River formations as found in areas to the north."

According to this interpretation, the fossil-bearing beds of the type Ojo Alamo are of Late, but not latest, Cretaceous age, and are probably of late Montana age. Triceratops and Tyrannosaurus which occur in the latest Cretaceous (Lance and Hell Creek formations) have not been reported to occur in the San Juan Basin.

Fragmentary plants collected from rocks assigned by Reeside (1924) to the Ojo Alamo on the western side of the Central basin were examined by F. H. Knowlton (in Reeside, 1924, p. 31-32), who reported Tertiary affinities for some of the fossils, but expressed a lack of certainty of age because of the fragmentary nature of the fossils. Reeside (1924, p. $31-32$ ) argued that, in view of the uncertainty of 
identification and stratigraphic position of the dinosaur fauns of the type Ojo Alamo, the paleontologic data are inconclusive as to the age of the beds. He classified the Ojo Alamo as Tertiary(?).

Dane (1936, p. 121) stated that "paleontologic evidence tends very strongly to support the view that there is no hiatus between the Ojo Alamo sandstone and the underlying Kirtiand shale and that the Ojo Alamo sandstone should be classified as Cretaceous."

Recently, Anderson (1960, p. 9-10) has reopened the question of the age of the Ojo Alamo. He has suggested that the microflora at the base of the Ojo Alamo has a "Tertiary ecologic aspect" but is not necessarily Tertiary from the standpoint of common forms. A florule from the middle of the Ojo Alamo is said to be more closely related to the Nacimiento florule than to the Kirtland florule. Anderson sug gests further that the dinosaur remains might have been reworked from older beds, or that the dinosaurs may actually be the same age as those of the Lance, or even younger.

To summarize the evidence presented in published reports, the faunal evidence indicates that the dinosaux-bearing beds assigned to the Ojo Alamo by previous workers are late Montana age, whereas the floral evidence indicates early Tertiary age, Reeside (1924, p. 32) admitted that the conflicting paleontologic evidence is inconclusive, and based his Tertiary(?) age assignment at least partly on structural evidence, 
stating that there is an important hiatus between the pre-0jo Alamo deposits and the Ojo Alamo sandstone, as determined by stxatigraphic overlap of older formations by the Ojo Alamo. Anderson $\{1960$, p. 2\} also bases his arguments essentially on a structural basis when he states that the "most significant ecological change takes place between the Kirtland and Ojo Alamo 1 florules with the influx of moxe than 70 percent Podocarpus pollen and associated upland species of Ulmoideipites. However, it is apparent that structural evidence alone is not sufficient to establish the temporal boundary between the Cretaceous and Tertiary, inasmuch as the San Juan Basin and its bounding uplifts began to be formed at least as early as Pictured Cliffs time, and the deformation continued episodically well into the Eocene at least.

The conflict between the floral and faunal evidence of age may be the result of the inclusion in the Ojo Alamo of rocks that are of similar lithology, but of different ages, and are separated, at least near the margins of the Central basin, by an erosional and slightly angular unconformity. The persistent unit of sandstone mapped as the Ojo Alamo by the present writer in the southern part of the area is clearly unconformable on the underlying undivided Fruitland formation and Kirtland shale. The unit persists across the southern part of the area, and is apparently the thin but persistent sandstone mapped as Ojo Alamo farther to the northwest by Dane (1936). Dane (1936, p. 121) has 
stated that "the thickness of the Ojo Alamo is variable, owing la gely to the fact that the base is irregular and not everywhere at the ne stratigraphic position." At places the persistent Ojo Alamo sandstone rests unconformably on lenticular sandatone of the Kirtland formation, probably accounting for the irregularities described by Dane who seems to have included, at some places, lenticular beds of the upper par of the Kirtland with the persistent sandstone of the Ojo Alamo.

The persistent sandstone unit mapped as Ojo Alamo by the writer seems to be equivalent to rocks described by Sinclair and Granger (1914, p. 300-302) as the "conglome ratic sandstone with fossil logs" below the "Puerco formation" and above the upper dinosaurbearing shales in the vicinity of Ojo Alamo. Sinclair and Granger remarked that the conglomeratic sandstone rests with disconformity on the dinosaur-bearing shales, but they attributed no particular significance to this disconformity. In defining the Ojo Alamo sandstone, Bauer (1916, p. 275-276) included the upper conglomeratic sandstone, the dinosaur-bearing shale, and a lower thin bed of pebble conglomerate in the formation. Bauer considered the Ojo Alamo to be "essentially a sandstone including lenses of shale and conglomerate" and indicated that the medial dinosaur-bearing shale is present only in a limited area, and the upper and lower conglomeratic sandstones merge east and west of this area. However, a study of Bauer's stratigraphic sections indicates that the medial dinosaur-bearing shale does not grade out 
laterally, but that much of it is cut out by an eroticnal surtace at the base of the upper sandstone.

Because of poor exposures it is not possible to trace the Ojo Alamo sandstone continuously northward from the type locality to the San Juan River near Farmington. However, the discontinuously exposed beds seem to be mainly the upper sandstone. On the south side of the San Juan River, the lower half, approximately, of the thick sequence of sandstone assigned to the Ojo Alamo by Reeside $(1924$, p. 30$)$ is probably equivalent to the persistent, upper sandstone of the type locality. R. B. O'Sullivan and the writer found that the upper half of the thick sandstone on the San Juan River is split by several southwardthickening tongues of shale of the "Puerco and Torrejon formations" (the Nacimiento formation in present terminology), and most beds of the upper half of the sandstone tongue out southward into rocks probably equivalent to the "Puerco formation" at Ojo Alamo. Hayes and Zapp (1955) concluded that "no unconformity is present in the several hundred feet of sedimentary rocks that succeeds the Kirtland shale in this area . . . "between the San Juan River west of Farmington and the Colorado-New Mexico line. However, R. B. O'Sullivan and the writer found that the Ojo Alamo sandstone rests with erosional unconformity on rocks assigned by Reeside (1924, p1, 1) to the McDermott formation between Barker Arroyo and Pinyon Mesa northwest of Farmington. Along the west side of Pinyon Mesa a well-exposed channeled muxace at the base 
of the Ojo Alamo cuts out at least 150 feet of underlymu feddish shate containing thin pebble-bearing sandstone similar to the dinosaur-bearing beds at Ojo Alamo. Locally, on the east side of La Plata River between Pinyon Mesa and Farmington, the reddish beds below the Ojo Alamo are absent or very thin, and they are only about 30 feet thick south of the San Juan River near Farmington.

On the basis of relations observed in the present area and the relations described above, it seems likely that there is an unconformaty at the base of the persistent upper conglomeratic sandistone of the type Ojo Alamo on the eastern, southern, and western margins of the Ceatral basin. The temporal significance of channeling at the base of conglom eratic sandstones has been questioned; nevertheless, this channeling, at places, has removed as much as several hundred feet of Cretaceous beds beneath the persistent upper sandstone of the Ojo Alamo, and it is quite possible that the missing beds were of Lance (latest Cretaceous) age.

A survey of the descriptions of localities from which "Ojo Alamo" dinosaur fossils were collected ${ }^{1}$ shows that they were all collected near the type locality from beds beneath the persistent upper conglomeratic sandstone. These dinosaur-bearing beds are somewhat similar lithologically to dinosaur-bearing beds of the McDermott member of the

1 Brown (1910), Sinclair aid Granger (1914), Bauer (1916), Gilmore (1916, 1919, 1922), Ree ids (1924). 
Animas formation at its type locality (keside, 1924, p. 26; see also Baltz, 1953; Barnes, Baltz, and Hayes, 1954) and also to unit C of the undivided Fruitland formation and Kirtland shale of the present area. No vertebrate fossils are reported to have been found in the persistent upper conglome ratic sandstone anywhere in the basin. Sinclair and Granger (1914, p. 301) report finding a badly-worn centrum of a dinosaur vertebra lying loose on the surface of the upper sandstone near Barrel Spring. They reasoned that it probably was not carried to this point by Indians "who are afraid of fossil bones", and express the opinion that it may have weathered from the sandstone, although "some may question its value as an index fossil." Regardless of the possible timidity of the Indians, the badly worn condition of the vertebra suggests transportation by natural means, and if it did actually weather from the upper sandstone it may have been reworked from underlying beds before being deposited in the upper sandstone (if indeed it was).

Aside from this questionable occurrence of a dinosaur bone, the only fossils reported to have been found in the upper persistent sandstone are plant fossils. The fossil logs which are cornmon at many places have not been reported to have any determined stratigraphic significance. The plant fossils assigned a questionable Tertiary age by Knowlton (in Reeside, 1924, p. 31-32) were collected on the western side of the Central basin from rocks which are probably 
equivalent to the upper persistent sandstone of the Ojo Alamo. The Ojo Alamo 2 florule of Anderson (1960, p. 5) was collected from rocks which the present writer mapped as the Ojo Alamo sandstone, and which are believed to be equivalent to the upper conglomeratic sandstone of the type Ojo Alamo. The "Ojo Alamo 1" florule of Anderson was collected from rocks which may be either at the top of unit B of the undivided Fruitland formation and Kirtland shale or at the base of the Ojo Alamo. According to Anderson (1960, p. 9) both the floruled are related more closely to the Nacimiento florules than to the Kirtland florules. Anderson states that the most significant ecologis change takes place between the Kirtland and Ojo Alamo florules but states also that, if the boundary of the Cretaceous and Tertiary were to be placed on the basis of common forms alone, it would be between the two Ojo Alamo florules.

To summarize, the rocks mapped as Ojo Alamo sandstone in the present area rest with slight angular and erosional unconformity on older rocks, and probably correlate with the upper sandstone of the Ojo Alamo at the type locality. This sandstone rests with erosional disconformity on dinosaur-bearing beds, and only plant fossils suggesting Tertiary age have been found in it. For these reasons the Ojo Alamo sandstone in the present area is assigned to the Tertiary(?). It should be stated here that the contact of the Ojo Alamo and underlying rocks is a physical feature and is not considered to be a time-stratigraphic surface. 
Nacimiento Formation

Definition

Tertiary rocks in the valley of the Rio Puerco southwest of Cuba were named the "Puerco marls" by Cope (1875, p. 1008-1017). Paleocene fossils from the Puerco of Cope (collected 50 miles west of the Rio Puerco) were studied by Matthew (1897, p. 259-261) who found two distinctly different faunas. He restricted the name Puerco formation to the rocks containing the older fauna, and proposed the name Torrejon formation for the rocks containing the younger fauna. Matthew credited the name Torrejon formation to J. L. Wortman who had dis tinguished the differing stratigraphic positions of the two faunes in the field. The name was taken from arroyos considered to be the heads of Arroyo Torrejon. These arroyos in the southwestern part of the present area are forks of what is now called Encino Wash, a tributary of Arroyo Torrejon (spelled Torreon on some maps) which lies south of the present area. Gardner (1909) mapped the (then unnamed) Ojo Alamo sandstone and overlying beds including the thick sandstones capping Mesa de Cuba as the Puerco formation. Subsequently, Gardner (1910, p. 713) proposed the term Nacimiento group to include both Puerco and Torrejon formations, specifying (p. 717) that along the Rio Puerco south and west of Nacimiento (now known as Cuba) the Puerco formation is 558 feet thick, and the overlying Torrejon formation is 276 feet thick. 
The lower limit of the Puerco formation described in Gardner's type section (1910, p. 717) does not correspond to the lower limit on his map (pl. 2) as will be discussed. Also, most of Gardner's (1910, p. 717) Torrejo 2 formation at the type locality of his Nacimiento group consists of sandstone beds which Cope (1875) specifically placed above his Puerco marls and seems to have correlated with the sandstones of the "Eocene" at the "portals of Canoncita de las Vegas" (Canyoncito de las Yeguas on Fig. 2 of the present report). Renick (1931,p. 51-53) mapped the Puerco and Torrejon formations as an undivided unit having asout the same upper and lower stratigraphic boundaries as the map unit called the "Puerco formation" in Gardner's earlier (190s) paper, and the rocks described as Puerco and Torrejon formations in Gardier's later (1910) paper.

Dane (1936) mapped a restricted unit as the Puerco(?) and Torrejon formations. The lower part of Gardner's (1909, pl. 2; 1910, p1. 2) Puerco formation was mapped by Dane as the Ojo Alamo sandstone. The sandstone beds capping Mesa de Cuba, and other mesas to the west, that Gardner had included in the Torrejon fornation were mapped by Dane as part of the Wasatch formation (now classified as the San Jose formation of Econe age). Woot and Northrop (1946) mapped the Puerco and Torrejon formations at the same undividec unit mapped by Dane (1936). In a later work, Dane (1946) used the 
term Nacimiento formation for the rocks he had mapped earlier as the Puerco(?) and Torrejon. Simpson (1948, p. 272-273) agreed with this usage and proposed that "Puerco" and "Torrejon" be coneidered only as names of faunal zones in the Nacimiento formation inasmuch as nobody has succeeded in mapping as separate lithologic units the containing the Puerco and Torrejon fossils.

Dane (1946) traced the Nacimiento formation from the vicinity of Cuba northward along the east edge of the San Juan Basin, and found that it is equivalent generally to rocks mapped as the Animas formation of Cretaceous and Paleocene age by investigators in Colorado. For this reason, Dane (1946) arbitrarily restricted the use of the term Nacimiento formation to the area south of Canyoncito de las Yeguas in T. 25 N., R. 1 E. and applied the term Animas formation to approximately the same rocks north of Canyoncito de las Yeguas. The Animas formation (Reeside, 1924, p. $32-33$ ) has been traced eastward from its type locality on the Animas River near Durango, Colorado around the northern part of the Central basin (Zapp, 1949; Barnes, 1953; Wood, Kelley, and MacAlpin, 1948; Dane, 1946 and 1948) to the northern part of the present area. However, the rocks classified as Animas formation in the present area by Dane $(1946,1948)$ are lithologically more similar to those of the typical Nacimiento formation than to typical Animas rocks. A lithologic division between the Animas and Nacimiento facies can 
probably be made in Colorado. On the northwest side of the Central basin such a division is possible (Baltz, 1953, p. 45-46).

In the southern and southeastern parts of the present area, the Nacimiento formation of this report is approximately the same as the unit mapped as the undivided Puerco(?) and Torrejon formations by Dane (1936) and by Wood and Northrop (1946). However, north of Canyoncito de las Yeguas, rocks classified by Dane $(1946,1948)$ as being in the lower part of the Animas formation are correlated by the present writer with the upper part of the undivided Fruitland formation and Kirtland shale, and the Ojo Alamo sandstone. Beds above the Ojo Alamo sandstone in the northern part of the area that were designated as the Animas formation by Dane are designated by the present writer as the Nacimiento formation, and the term Animas formation is not used for rocks in the present area.

\section{Type Locality}

There is some difficulty in determining exactly which rocks were meant to be included by Gardner (1910, p. 717) in the "Nacimiento group" at its type locality. Although he did not specify the exact locality at which the type section was measured, most workers have assumed that the section was measured at the south end of Mesa de Cuba in the northwest part of T. 20 N., R. 2 W. Comparison of Gardne $t^{4}(1910)$ type section with sections measured by Simpson 
This report E
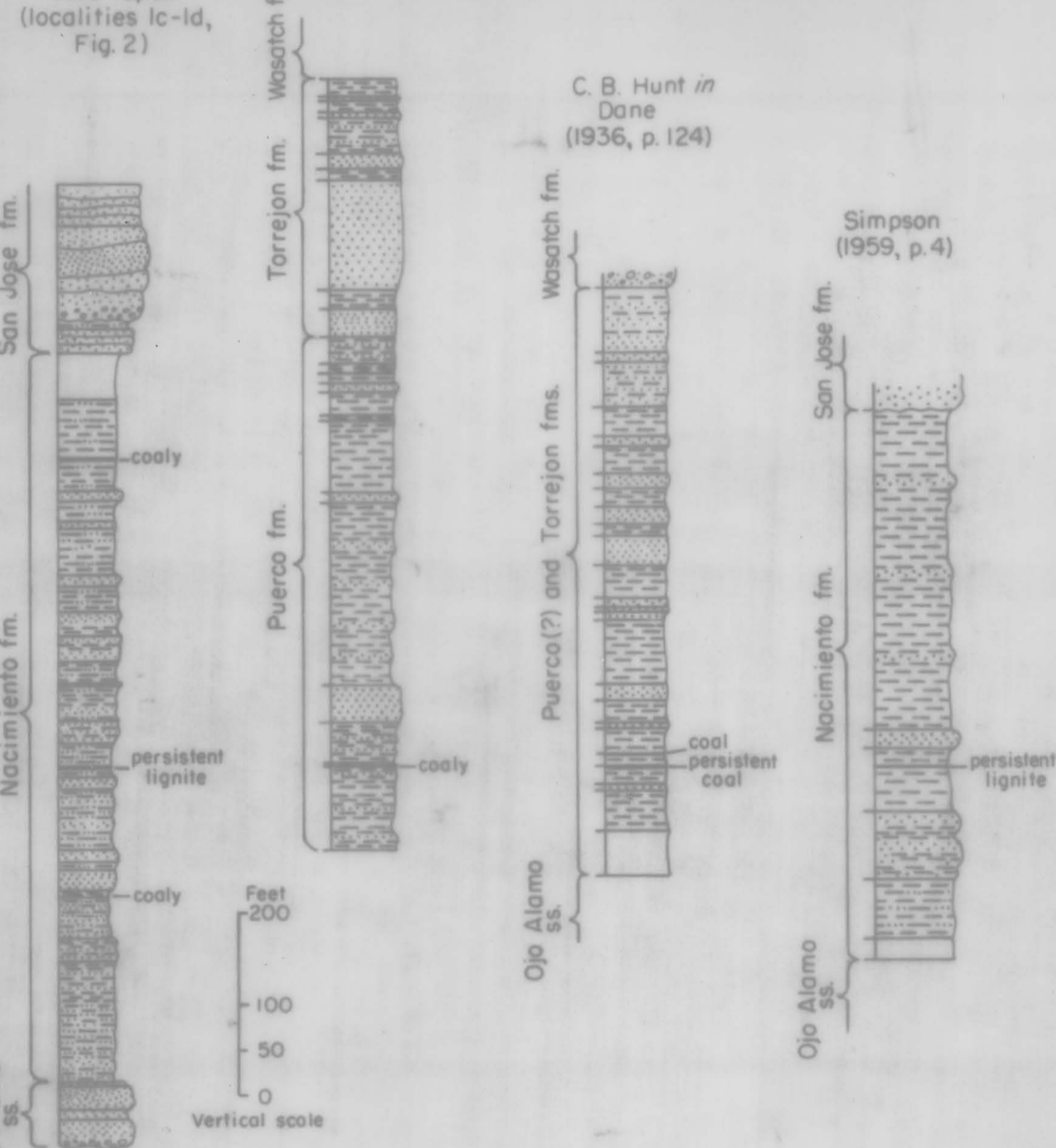

EXPLANATION

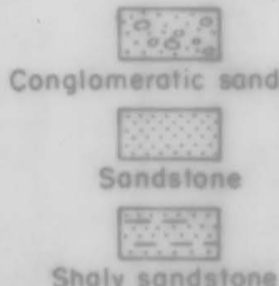

․ㅡ물

Siltstone

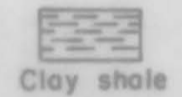

Cool or lignite

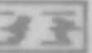

Carbonaceous shale

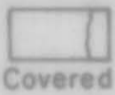

Figure II.--Comparison of stratigraphic sections of the typical exposures of the Nocimiento formation of the south end of Mesa de Cubo 
$(1959, \mathrm{p} .4)$ and by the present writer (Fig. 11) indicates that Gardner

Ifd measure the part of his section which he designates as the "Puerco formatioa" at the southern tip of Mesa de Cuba. The lower 170 feet of rocks assigned to the "Torrejon formation" by Gardner consist mostly of sandstone and are probably the sandstone beds capping Mesa de Cuba. These sandstones are now classified as part of the San Jose formation. The shale and thin sandstone comprising the upper 106 feet of the rocks assigned to the "Torrejon formation" by Gardner must have been measured elsewhere because only the lower 170 feet of sandstones are preserved at the south end of Mesa de Cuba.

Gardner's (1909 and 1910) maps include with the "Nacimiento group" the sandstone now classified as the Ojo Alamo. Renick (1931, p. 51-52), Dane (1932), and Simpson(1959, p. 16-19) have supposed that Gardner's type section of the "Puerco formation" includes at the base the Fruitland and Kirtland, and that the fourth unit above the base-a sandstone 40 feet thick--is the Ojo Alamo. However, Gardner's section was measured probably at or near the locality of measurement (1d on Fig. 2) of the upper part of the present writer's composite section of the Nacimiento formation (described at the end of this report) north of the Torreon road in sec. $11, T .20$ N., R. 2 W. If this is correct, the second unit from the base of Gardner's section ("shale, very dark, local coal streaks") is a prominent and persistent band of 
Lignite above a small bench, and about 90 to 100 feet above the valley floor. This lignite is equivalent to unit 71 of the present writer's stratigraphic section. Thus, the base of Gardner's type section is about 250 feet stratigraphically above the Ojo Alamo sandstone. The lignite is probabiy the "persistent lignite" shown in the third unit above the base of Simpson's (1959, p. 4) section, and the fifth unit above the base of Hunt's section (in Dane, 1936, p. 124). Hunt's section indicates that the "Puerco(?) and Torrejon" fo:mations are about 633 feet thick, and Simpson (1959, p. 19) states that his measurement of these same rocks, now called the Nacimiento formation, is about 600 feet. However, the composite section measured by the present writer is about 800 feet thick, and this thickness accords fairly well with a thickness of about 860 feet for the Nacimiento formation at the Sun Oil Co. No. 1 McElvain well in sec. 23, T. 21 N., R. 2 W. (see Fig. 7). If the base of the Nacimiento formation is defined as the top of the Ojo Alamo sandstone, there are almost 200 feet of shale and thin sandstone beds in the lower part of the Nacimiento that have not been described at the type locality by previous workers. These rocks are well exposed on the hills north of Arroyo Chiuilla in secs. 13 and 14, T. 20 N., R. 2 W. (locality 1c on Fig. 2), are described in a stratigraphic section at the end of the present report, and are shown graphically on Figure 3. 


\section{Extent and Thickness}

The Nacimiento formation is present above the Ojo Alamo sandstone throughout the present area of investigation. The Nacimiento crops out in the Penistaja Cuestas sector across the southern part of the area where it forms low rounded hills of drab clay, siltstone, and soft sandstone. Thin resistant sandstones in the upper one-third of the formation form low benches and small, northward-sloping cuestas. In the southwestern part of the area at the Shell Oil Co. No. I Pool Four well in the SE $1 / 4$ sec. $22, T .21$ N., R. 5 W. the Nacimiento is about 850 feet thick. The composite stratigraphic section measured in the SE 1/4 SE 1/4 sec. 14, and at the south end of Mesa de Cuba in sec. 11, T. 20 N., R. 2 W. indicates that the Nacimiento is about 800 feet thick west of the Rio Puerco.

In the San Pedro Foothills the Nacimiento formation is discontinuously exposed in the walls of canyons and sides of valleys where its beds of somber clay and thin sandstone are vertical to slightly overturned, or dip steeply to the west. The thickness is varied, pe rhaps partly because of squeezing of the shale in the belt of sharp folding, but mainly because of angular and erosional unconformity with overlying rocks of the San Jose formation. Near the center of sec. 11, T. 21 N., R. 1 W. the Nacimiento is 537 feet thick. Farther north in T. 22 N. the Nacimiento is thinner, but the formation is estimated to be about 
1,000 feet thick north of San Jose Creek in sec. 34, T. 23 N., R. 1 W. The formation seems to become thinner again in sec. 15, T. $23 \mathrm{~N} .$, R. $1 \mathrm{~W}$.

In the southern part of the Northern Hogback Belt the steeply west-dipping rocks of the Nacimiento formation are poorly exposed in discontinuous low ridges separated by alluvial valleys. In sec. 20 , T. 24. N., R. 1 E. the Nacimiento is about 550 feet thick, or possibly slightly more because the base of the formation was not determined with certainty owing to poor exposures. In the western half of sec. 8, T. 24 N., R. 1 E. the base was not cietermined with certairty but the Nacimiento formation is at least 1,250 feet thick. Farther to the north the Nacimiento formation is better exposed as the west dip of the beds becomes less steep. North of Canyoncito de las Yeguas, sandstones of the formation hold up ridges and spurs west of the Ojo Alarno cuesta. Neax the center lines of secs. 17 and $18, T, 25$ N., R. 1 E. the Nacimiento formation is almost 1,400 feet thick with the base not exposed at the point of measurement.

Although the thickness is irregular in the outcrops along the eastern edge of the area, it is apparent that the Nacimiento formation thickens generally northward. In the subsurface a similar but more regular northward thickening of the Nacimiento takes place. The formation is 800 to 850 feet thick in the southern part of the area, anc is 
as much as 1,750 feet thick near the northern edge of the area. Weil data indicate also that the Nacimiento thins irregularly eastward in the subsurface near the eastern edge of the Central basin.

\section{$\underline{\text { Lithology }}$}

The Nacimiento formation consists of shale and interbedded soft to resistant sandstone. These rocks are of two different lithologic facies in the northern and southern parts of the area; however, the lateral change in facies takes place so gradually and exposures are so discontinuous on the eastern side of the area, that it is impossible to map any logical lithologic boundary between facies. The Nacimiento formation of the southern part of the area is a facies consisting mainly of clay shale with some interbedded soft sandstone and a few resistart sandstone beds. In the northern part of the area the Nacimiento contains a greater proportion of sandstone, and near the northern edge of the area more than half of the formation consists of sandstone.

In the vicinity of the southern part of Mesa de Cuba the Nacimiento consists of four more or less distinguishable units. The lowest unit is soft, gray to light olive-gray clay shale with purplish bands, and contains numerous thin beds of lenticular soft siltstone and shaly fine - to coarse-grained sandstone, all about 130-150 feet thick in sec. 14, T. 20 N., R. 2 W. Above this is a unit of gray clay and soft, highly lenticular, fine-grained to very coarse grained, white-weathering 
sandstone containing one or two thin beds of irrpuxe coal, all about 120 feet thick in sec. 12, T. 20 N., R. 2 W. Next above is a unit of soft olive-green and gray clay and siltstone containing several beds of lenticular, soft, fine-to coarse-grained, argillaceous sandstone and, near the top, a conspicuous bed of black to dark-brown lignite (equivalent to the previously mentioned lower lignite in the sections of Gardner, Hunt, and Simpson). This unit is about 115 feet thick in sec. 11, T. 20 N., R. 2 W., where it forms rounded topographic spurs near the foot of Mesa de Cuba. The highest unit of the Nacimiento formation consists of variegated light-purple, gray, and olive-green clay and siltstone containing lenticular yellow and white argillaceous soft sandstone, and several thick ledge-forming buff to brown sandstone beds. The unit is about 425 feet thick in section 11 , and forms steep ledgy slopes below the caprock of Mesa de Cuba. The prominent, lenticular, ledge-forming sandstones are interbedded in the shale of the lower two-thirds of the highest unit of the Nacimiento. These sandstones, or sandstones laterally equivalent to them, hold up small cuestas at many places farther west in the southern part of the arta. The upper one-third of the unit consists mainly of shale, but contains a zone of lignite which forms a conspicuous outcrop band associated with manganiferous sandstone at places across the southern part of the area. The four units of the Nacimiento were not mapped; however, the units seem to persist across the southern part of the area, and also persist 
for some distance to the north in the San Pedro Foothilis.

In the. San Pedro Foothills northward from the northern part of T. 22 N, , R. 1 W., the proportion of sandstone in the Nacimiento formation increases. At places, the lower part of the formation contains thick, fine - to coarse-grained sandstone and interbedded olivegreen and gray carbonaceous shale. The middle of the formation is poorly exposed, but where observed, it seems to consist mainly of gray to olive-green shale with interbedded lenticular sandstone. The upper part of the Nacimiento con_isis of several beds of ridge-forming, conglomeratic, coarse-grained, arkosic sandstone interbedded with daxk-gray and olive-green shale and shaly sandstone. The upper sandstones of the Nacimiento are lithologically similar to the overlying sandstone of the San Jose formation, but the Nacimiento sandstones are generally thinner and the dark-gray and olive-green shale writh which they are interbedded is unlike the variegated shale of the San Jose. In the San Pedro Foothills between the north fork of the Rio Puerco and the upper part of Arroyo Naranjo, these upper arikosic sandstones of the Nacimiento are cut cut by the unconformity at the base of the San Jose. The upper sandstones are pr: nt locally in sec. 16 and part of sec. 20, T. 21 N., R. 1 W. but seem to be cut out by the unconformity farther south.

The above described general lithologic charactex of the Nacimiento 
formation seems to persist in the Northern Hogback Belt as far as the northern edge of the area. However, where the lower part of the Nacimiento was observed it seems to have a smaller proportion of sandstone north of the central part of T. 24 N., R. 1 E. than it does south of here. The zone of the upper conglomeratic arkosic sandstones of the Nacimiento is varied in thickness, and these sandstones are absent lọcally, as in sec. 20, T. 24 N., R. 1 E. where the upper part of the Nacimiento is cut out because of angular unconformity with the San Jose formation. North of here the upper conglomeratic arkosic sandstones of the Nacimiento are persistent, and are overlain by dark-gray and olive-green sandy shale upon which the San Jose formation rests at outcrops and in the subsurface of the northern part of the area.

In the subsurface the lithology of the Nacimiento is similar to that of the surface exposures. In the southern part of the area the Nacimiento consists mainly of shale, but the proportion of sandstone increases northward. The upper conglomeratic arkosic sandstones exposed at the surface in the Northern Hogback Belt are fairly persistent in the subsurface in a northwest-southeast direction, but to the south and southwest the sandstones thin and become discontinuous lenticular deposits enclosed in beds which are predominantly shale. Near the outcrops of the Nacimiento formation in the southern part of the area, the upper part of the Nacimiento is not present because 
of the erosional and slightly angular unconformity at the base of the underlying San Jose formation (Figs. 5,7). Intraformational thickening occurs beneath the zone of the upper conglomeratic arkosic sandstones of the Nacimiento, and they may be locally unconformable on the part of the Nacimiento beneath them.

The sandstone beds of the Nacimiento formation in the Northern Hogback Belt contain much fresh angular orthoclase feldspar and other detritus that indicate a source terrane of Precambrian rocks. Most of the pebbles scattered through the sandstones are quartz and quartzite, but a few pebbles of volcanic rocks were observed in the northeastern part of the area. Thick beds of volcanic conglome rate, tuffaceous sandstone, and weathered tuff, such as characterize the Animas formation on the northern side of the Central basin in Colorado were not observed in the Nacimiento formation. However, many of the sandstone beds contain ferromagnesian minerals, and beds of olive-green chloritic shale are common. These sediments may have been derived from the erosion of weathered volcanic rocks present in the. San Juan Mountains region. Beds of bentonitic shale are present at places in the Nacimiento. Much of the Nacimiento formation consists of shale, siltstone, and fine - to medium-grained sandstone similar to Cretaceous rocks and presumably derived by erosion from these rocks. In the southern part of the area there is, al places, an almost chaotic intergrading of soft argillaceous sandst ne, siltstone, and clay shale in the lower part. 
of the Nacimiento. Sandstones in the lower part of the Naciraiento contain mixtures of coarse, angular grains and fine- to medium-grained, well-rounded sand with occasional pebbles. These poorly sorted sediments seem to be a mixture of first-cycle material derived from Precambrian rocks, and second-or third-cycle material derived from Cretaceous and older sedimentary rocks, and "dumped" into a subsiding basin of deposition. Sediments of the middle and upper parts of the Nacimiento are better sorted, and more evenly bedded.

The size and shape of the basin of deposition of the Nacimiento formation and equivalent parts of the Animas formation can be inferred partly from existing outcrops of these rocks. The Nacimiento formation and most of the Animas formation are restricted presently to the Central basin, although rocks of the Animas formation occur at places on the southern flanks of the San Juan Mountains (Wood, Kelley, and MacAlpin, 1948; Cross and Larsen, 1935; Larsen and Cross, 1956). Baltz (1953, p. 44-45) found that angular unconformities occur within the Animas formation, and between rocks mapped as the Animas formation and the Nacimiento formation along the Hogback monocline south of Durango, Colorado. R. B. O'Sullivan and the writer observed similar unconformable relations between the Nacimiento formation and rocks probably equivalent to the lower part of the Anima and to the Ojo Alame along the Hogback monocline northwest of Farmington, New Mexico. 
These relations indicate that the lower part of the Anirna 8 formation, the Ojo Alamo sandstone, and the lower part of the Nacimiento formation probably were distributed on at least part of the Four Corners platform, and on the flanks of the San Juan dome, as weil as in the Central basin before folding began on the westem side of the Central basin. Much of the Animas and Nacimiento formations in the northwestern part of the basin consists of sediments reworked from Cretaceous rocks and from lower beds of the Animas formation ceposited on the Four Corners platform before the folding began. Chaotic bedding and poor sorting of rocks in the Nacimiento and Animas formations adjacent to the Hogback monocline are probably the resuit of "dumping" of sediments e roded from the soft Cretaceous rocks on the Four Corners platform. The poorly sorted rocks seem to hâve been deposited as fans at the mouths of sediment-laden streams debouching into the Central basin during Paleocene time. Probably, most of the rocks of the Animas and Nacimiento formations were not deposited in areas very far west of the Hogback monocline.

The northern limit of the early Tertiary (Nacimiento-Animas) depositional basin is not known with certainty, inasmuch as no unconformities have been reported within Animas rocks on the northern and northeastern edges of the Central basin. In this region the Anima is overlain with angular unconformity by the Blanco Basin formation of 
Eocene(?) or Oligocene(?) age (Larsen and Cross, 1956, p. 61) which laps onto Cretaceous and older rocks in the southeastern San Juan Mountains. The main volcanic facies of the Animas formation is in the northwestern part of the Central basin. The McDermott member (Baltz, 1953, p. 37-41; Barnes, Baltz, and Hayes, 1954) seems to have been erupted from centers in the vicinity of the laccolithic domes of the La Plata Mountains northwest of Durango, Colorado. Larsen and Cross (1956, p. 57) suggested that the volcanic sediments of the main part of the Animas are about the same age as some of the intrusive centers in the northern and northwestern parts of the San Juan Mountains. The abundant granitic and metamorphic detritus in the Aninas must have been derived from Precambrian rocks, possibly from the San Juan dome, and possibly from as far away as the Gunnison and Sawatch uplifts, and the Brazos uplift. The Brazos uplift was proBably continuous with the Sangre de Cristo uplift prior to Miocene time, and the Sangre de Cristo uplift shed detritus into the Raton basin in Paleocene time (Johnson and Wood, 1956); thus this uplift was probably the northeastern boundary of the Animas-Nacimiento basin. The southeastern edge of the basin is unknown. The writer observed no evidence that would indicate that the Nacimiento uplift was tectonically active during deposition of the Nacimiento formation (and equika lent rocks of the Animas formation), and these rocks may have been 
continuously distributed across this region prior to early Eocene time. The southern margin of the Nacimiento-Animas depositional basin also is unknown. Possibly the Zuni and Defiance uplifts were tectonically active and defined a southern limit of the depositional basin. Paleocene rocks are not known to occur in southern New Mexico, although Kelley and Silver (1952, fig. 14, p. 114, and p. 116) have postulated that the McRae formation of the Caballo Mountains region may be equivalent to the Animas formation.

To summarize, the two sedimentary facies of the Nacimiento formation in the present area appear to have been deposited in slightly different environments, and the sediments of the shale facies in the southern part of the area probably were derived mainly from different source areas than the sediments of the coarse sandstone facies of the northern part of the area. The coarse sandstone facies (of the Nacimiento formation and equivalent rocks of the Animas formation) probably is part of a huge apron of volcanic and orogenic debris eroded from rising highlands lying north and northeast of the San Juan Basin, and spread to the southwest into the basin. The shaly facies of the Nacimiento which is present across the southwestern onethird of the Central basin, is composed partly of finer grained material deposited at the distal edges of the apron, but the shaly facies consists in large part of reworked Cretaceous sediments eroded from the Hour Corners platform and possibly from the southerb part of the Chaco slope. 
The lithology and contained vertebrate fossils of the Nacimiento formation indicate that it was deposited in a terrestrial environment. The lenticular sandstones are stream-channel deposits and the clays and siltstones were deposited on floodplains, alluvial fans, and in ephemeral lakes. The basin of deposition may have been poorly drained and swampy. The sediments of the shaly facies in particular seem to have been deposited in a paludal and lacustrine environment, inasmuch as, they are highly carbonaceous in places, and they contain fossil fish and a reptilian fauna characterized by crocodiles, the aquatic lizard Champsosaurus, and many genera and species of turtles (Gilmore, 1919; see also Sinclair and Granger, 1914, p. 309-310 and 313). The microflora of the Nacimiento (Anderson, 1960, p. 8) also indicates deposition in a lowland environment with temperate upland environments not far distant.

\section{Contacts}

Where the contact of the Nacimiento formation and underlying Ojo Alamo sandstone was observed, no evidence of unconformity was discovered. The contact seems to be gradational through a few inches to several feet of sandy shale. Evidence of intertonguing in the subsurface was presented in the discussion of the Ojo Alamo.

The contact of the Nacimiento and the overlying San Jose formation is one of angular and erosional unconformity throughout most of 
the area. The erosional nature of the contact is appereht at thicet exposures, and at many places coarse-grained, pebble-bearing sandstone of the San Jose rests in channels cut in the upper part of the Nacimiento.

In a branch canyon of one of the tributaries of the upper Rio Puerco in the SW $1 / 4$ NE $1 / 4$ SW $1 / 4$ sec. 11, T, 21 N., R. 1 W., the angular nature of the contact between the San Jose and Nacimiento formations is apparent. Here the Nacimiento beds are overturned and dip $85^{\circ}$ east. The basal sandstone of the San Jose dips about $69^{\circ}$ west at the contact. About 75 feet west of the contact the dip of the San Jose flattens abruptly to about $10^{\circ}$ west. On the north wail of the deep canyon just north of the se exposures the basal sardstone of the San Jose was observed to cut out almost 200 feet of Nacimiento beds between the bottom of the canyon and the top of the north wall of the canyon.

In the SE $1 / 4 \mathrm{SW} 1 / 4$ sec. $23, \mathrm{~T} .22 \mathrm{~N} .$, R. 1 W., faulted, fossil-bearing shale and sandstone of the San Jose rest unconformably on rocks as old as the Lewis shale. These outcrops were first observed and their significance recognized in 1955 by R. L. Koogle who kindly showed them to the writer.

Farther north, exposures are such that the unconformable relations cannot be observed directly. However, the irregular thickening and thinning and the absence of the upper conglomeratic, arkosic 
sandstone unit of the Nacimiento at places in the San Pedro Foothills and Northern Hogback Belt indicate that folding and erosion occurred here after deposition of the Nacimiento. Near the center of sec. 20 , T. 24 N., R. 1 E. (and in the subsurface at the Reading and Bates No. 1 Duff well, sec. 24, T. 24 N., R. 1 W.) the Nacimiento is only about 600 feet thick, and the upper conglome ratic, arkosic sandstoces of the Nacimiento are not present beneath the San Jose, apparently because of angular unconformity. These upper beds are presunt, however, in secs. 7 and $8, T, 24$ N., R. $1 \mathrm{E}$. whe re the Nacimiento is at least 1,250 feet thick. North of Arroyo Blanco, the contact of the San Jose and the Nacimiento is one of erosional unconformity, but no discordance of dip was observed.

In the subsurface the southward thianing of the Nacimiento is partly intraformational thinning. However, correlation of lithologic units penetrated in deep wells shows that the basal sandstone of the San Jose bevels successively younger rocks of the Nacimiento from north to south, and the contact is thus one of erosion and slight angular unconformity.

Age and Correlation

The Nacimiento formation is of Paleocene age, and contains the classic terrestrial vertebrate faunas of that epoch of the Tertiary period. The history of the discovery and identification of these fossils 
has been discussed by Gardner (1910, p. 703-713), Sinclazr and Granger (1914, p. 298), Bauer (1916, p. 276-277), Reeside (1924, p. 35), Dane (1936, p. 122-123), Matthew (1937), and Simpson (1948, p. 271-273; 1959, p. 1-3).

The first fossil mammals found in the "Puerco marls" of Cope (1875) were collected by David Baldwin west of the present area and were described as "lowest Eocene" by Cope (1881). Gardner (1910) referred the "Nacimiento group" to the Eocene also. Sinclair and Granger (1914, p. 313) stated that both the "Puerco" and "Torrejon" formations had been referred to as "Basal Eocene", but thet." "more recently, Paleocene seems to be growing in favor". Matthew (1914, p. 381-382) discussed the use of the term "Paleocene" stating that "the typical and best known Paleocene fauna is that of the Puerco and Torrejon formations, Nacimiento terrane, of New Mexico" and indicated that the Puerco was of earliest Tertiary age. Appurentiy Matthew (1921, p. 220) changed his mind later and decided the Paleocene was Cretaceous. The U. S. Geological Survey was conservative in the matter of age assignment, and particularly in use of the term "Paleocene". Bauer (1916, pls. 64 and 69) assigned the Puerco and Torrejon to the Tertiary as shown by his map symbols ( $\mathrm{Tpt}$ ), but he did rot express a direct opinion in the text of his paper. Gilmore $(1919$, p. 9) considered the faunas as being "basal Eocene". Reeside (1924, p. 43-44) reviewed the fossil evidence and concluded that the 
Puerco and Torrejon we re early Tertiary in age, and assigned therk to the Eocene. Dane (1936, p. 122) also assigned the Puerco(?) and Torrejon to the Eocene, but in his later (1946) work assigned the Nacimiento formation to the Paleocene and Cretaceous(?).

The Puerco and Torrejon faunas are now accepted by most. workers as being the standards of reference for Norib American terrestrial faunas of early and middle Paleocene age, respectively. H. E. Wood and others (1941) proposed that the "Puercan" and "Torrejonian" be designated as provincial ages of the early and middle parts of the Paleocene epoch of the Tertiary period. Late Paleocene fossils occur in the northern part of the Central basin southeast of Durango, Colorado in beds mapped as the "Wasatch" formation by Reeside (1924), and Cross and Larsen (1935). The rocks containing the fossils were called the "Tiffany beds" by Granger (1917, p. 829$)$. Fossils of the Tiffany fauna were described by Matthew (1917), Matthew and Granger (1921), and by Simpson (1935a,b, c). "Tiffanian" now designates the provincial age of the late Paleocene (H.E. Wood and others, 1941; Simpson, 1948, p. 275-276).

Torrejonian fossils have been found in the upper part of the Nacimiento in Encino Wash (Arroyo Torrejun) and upper Arroyo San Ysidro in the southern part of the area. However, until recently no fossils had been reported from the Nacimiento formation at its type 
locality at the southern end of Mesa de Cuba. Recently Simpson (1959) reported Torrejonian fossils occurring west of Arroyo Chihuila (Arroyo Chiuilla on Fig. 2) several miles west of the southern end of Mesa de Cuba, and also northeast of Cuba. These fossils are distributed vertically from near the top of the Nacimiento to within 100 to 125 feet of what Simpson considers to be the base of the foimation. Puercan fossils have not been found in the area of the present report, nor have Tiffanian fossils been found. Thus, on the basis of the positive evidence presented by fossils, the Nacimiento formation of the present area can be dated only as middle Paleocene. However, the base of the Nacimiento (and top of the Ojo Alamo) are below the level indicated by Simpson in his section of the type locality, and there are more than 200 feet of beds in the lower part of the type Nacimiento from which fossils have not been collected. The lithology of the lower part of these beds is similar to that of the beds in the lower 75 feet of the Nacimiento which contain Puercan fossils at Kimbetoh Arroyo and Ojo Alamo Arroyo west of the present area (Sinclair and Granger, 1914, especially fig. 2). Thus it seems possible and even likely that beds of Puscan (early Paleocene) age are present in the vicinity of the Rio Puerco and elsewhere in the area of this report.

Dane (1946) has expressed the opinion that the rocks mapped as Wasatch in the northeastern part of the San Juan Basin include beds laterally equivalent to the Tiffany beds of late Paleocene age. He 
pointed out that the Tiffany fauna has not been found in New Mexico, but stated that vertebrate faunas of Eocere age have not been reported from the lowest 500 feet or more of the Wasatch in the southeastern part of the basin and the age of these beds is undetermined. However, Simpson (1948, p. 377) postulated that there is an important hiatus between the Nacimiento formation and the San Jose formation (Wasatch of Dane and previous workers), reasoning that the Nacimiento is probably no younger than middle Paleocene and reporting that he had found Eocene fossils within 50 feet of the base of the San Jose formation. Simpson (1959) has confirmed his earlier (1948) statement concerning the age of the upper part of the Nacimiento ia the southern part of the present area. The present writer has demonstrated that an angular unconformity exists between the Nacimierto and San Jose in the area between secs. 7 and $20, \ldots 24 \mathrm{~N}, \mathrm{R}, 3 \mathrm{E}$. The sandstone mapped as the basal part of the San Jose by the writer is also the unit judged to be the base of the San Jose by Simpson (personal communication, 1959) and Eocene fossils were found 50 feet above this sandstone. As the result of tracing and mapping the base of the San Jose, the writer is of the opinion that the sandstone beds at the base of the San Jose at the type locality of the Nacimiento are at about the same stratigraphic position as those in sec. $20, T .24$ N., R. 1 E. where Eocene fossils are present. This conclusion is substantiated also by subsurface correlations of the San Jose. These correlations also show a southward 
beveling of the upper part of the Nacirniento by the San Jose. Augular unconformity was observed at the base of the San Jose in sec. 11, T. 21 N., R. I W. Thus, it seems probable that the Nacimiento formation exposed at the surface in most of the area is of early and middle Paleocene age, and is overlain unconformably by early Eocene beds of the San Jose as suggested by Simpson (1948).

However, in the northern part of the area the Nacimiento is locally almost 1,800 feet thick. This is more than twice as thick as the Nacimiento exposed in the southern part of the area where Torrejonian fossils are present near the top of the formation. It seems reasonable that upper beds of the Nacimiento formation in the northern part of the present area might be of Tiffany (late Paleocene) age. The upper arkosic conglomeratic sandstones of the Nacimiento are lithologically similar to some of the beds containing the Tiffany fauna at the Mason quarry north of Tiffany Station in Colorado (Fig. 1). The Tiffany beds in Colorado contain large quantities of tuffaceous material and olivegreen shale more similar to the Animas formation than to typical San Jose rocks. The rocks several hundred feet above the beds containing the Tiffany fauna are more similar to typical San Jose rocks than are the Tiffany beds. Barnes (1953) mapped (bed "d") the rocks specified by Reeside (1924, p. 55-56) to be the basal arkose of the Wasatch at the northeru end of the H-D Hills about 12 miles north-northeast of the 
Mason quarry. Reeside had specified that Tiffany fossils occurred in the lower part of the beds he mapped as Wasatch. However, Barnes found that the base of the Wasatch (bed "d" of Barnes) as defined by Reeside's stratigraphic section could be traced southward to the south end of the H-D.Hills, and that the Mason quarry with its Tiffany fossils is about 280 feet below the position of rocks mapped as basal Wasatch at the north end of the H-D Hills. If Barnes'tracing of this contact is correct, Reeside's (1924, pl. 1) lower contact of the Wasatch in the valley of Los Pinos River north of Ignacio, Colorado is considerably lower stratigraphically than it is at the north end of the H-D Hills, and Reeside included in the Wasatch the Tiffany beds whose lateral equivalents he excluded from the Wasatch elsewhere. It is the writer's opinion, based on reconnaissance tracing of the base of the San Jose formation in much of the western and northern parts of the basin, that the Tiffany beds probably should be included in the Animas formation, and that they probably are below the stratigraphic position of the base of the typical San Jose. Detailed tracing of beds to supplement the observations of Barnes (1953) probably would solve this problem.

In summary, rocks mapped as the Nacimiento formation in the present area are probably of early (Auercan) and middle (Torrejonian) Paleocene age at the surface of most of the area. The upper part of the Nacimiento north of Arroyo Blanco in the Northern Hogback Belt 
could be of late (Tiffanian) Paleocene age. Because the Na ni to formation is so much thinner in the southern part of the a $T$ a tan the northern part, it is doubtful that rocks of late Falecoenc age are present in the Penistaja Cuestas sector. The Nacimiento formation of the present area surely correlates with most of the Animas formation in Colorado, but the lower beds of the Animas probably are equivalent to parts of the Ojo Alamo sandstone, and perhaps to part of the unit mapped as undivided Fruitland formation and Kirtland shale in the present area.

San Jose Formation

Definition

Resting on the Nacimiento formation with erosional and angular unconformity throughout the area is a sequence of sandstone and shale mapped by previous investigators as the Wasatch formation. The names "Green River" and later, "Wasatch", were applied to these rocks by Cope (1875 and 1877) who found Eocene fossils similar to those of the Wasatch formation of Wyoming. The Eocene fossils were found by Cope (1875) in two horseshoe-shaped areas of badlands south of "Canoncita de las Vegas" (now known as Canyoncito de las Yeguas) in the northeastern part of the present area. In his excellent summary of the history of the terminology of the Eocene of the San Juan Basin, Simpson 
(1948, p. 262) identifies the horseshoe-shaped badlands lentatively as the upper parts of Arroyo Blanco, and "Arroyo Almagre" (Almagre Arroyo on Fig. 2 of the present report).

In his first (1875) description of the rocks which he later (1877) called "Wahsatch", Cope described fossiliferous "variegated marls" lying above the massive sandstones in which "Canoncita de las Vegas" (Canyoncito de las Yeguas) is cut. Cope pointed out that the variegated bede closely resemble the Wasatch beds of Bear River, Wyoming. These variegated beds he definitely intended to include in the "Wahsatch" formation, but it is not certain that he intended to include the underlying massive sandstones also in the "Wahsatch". However, under the massive sandstones are rocks described by Cope as being "marls" of "mixed black and green colors" (the Nacimiento formation) which, he stated, are the lowest beds of the Eocene. Cope traced these beds southward for "40 miles" (actually about 25 miles) to the vicinity of Nacimiento (present-day Cuba). To these rocks he applied the name "Puerco marls", and seems to have considered the overlying thick sandstone (in turn overlain by the variegated "marls") west of the Rio Prierco as being the same as the sandstone beneath the variegated beds at "Canoncita de las Vegas". At any rate, by implitcation the sandstones were included with the "Wahsatch" variegated beds, and they definitely were not included with the underlying beds described as the 
"Puerco maxls". This terminology (emended to Wasatch) was generally accepted and perpetuated by most later workers in the San Juan Basin, although several revisions of nomenclature were proposed, mainly by C. R. Keyes. (See Simpson, 1948, p. 269-271 and 273-280, for a detailed discussion of the history of the terminology.)

Although the term Wasatch formation was used by later investigators for rocks in the present area, different investigators included different rocks in the formation. Gardner $(1909, \mathrm{pl} .2)$ mapped the thick variegated shales and interbedded sandstones (the variegated "marls" described by Cope) lying north of Mesa de Cuba as the Wasatch formation. The thick sandstones at Canyoncito de las Yeguas were excluded from the Wasatch by Gardner (1910, pl. 2), although in quoting Cope (1875), Gardner (1910, p. 703-705) inserted the term Wasatch in brackets after Cope's description of the sandstones at Canyoncito de las Yeguas. The thick conglomeratic sandstones of Mesa de Cuba and other mesas and cuestas farther west were mapped as the upper part of the Puerco formation by Gardner (1909) and later were specified (Gardner, 1910) to be the Torrejon formation. Renick (1931, p. 52) accepted Gardner's classification of the Torrejon and Puerco, and included the sandstones of Mesa de Cuba in the Torrejon. Renick (1931, pl. 1) mapped the base of the Wasatch at about the same stratigraphic position north of Cuba as did Gardner (1909, pl. 2). However, Penick (1931, p. 55, pl. 1) showed that Gardner's mapping 
of the base of the Wasatch along the foot of San Pedro Mountain was largely incorrect.

Dane (1936, p. 125, and pl. 39) mapped the Wasatch to include not only the variegated shale mapped as Wasatch by Gardner and by Renick, but also to include the thick sandstones capping Mesa de Cuba and the mesas and cuestas to the west that Gardner and Renick had included in the Torrejon formation. Dane $(1946,1948)$, and Wood and Northrop (1946) placed the lower contact of the Wasatch at the base of thick arkosic sandstone lying under the variegated shales in the San Pedro Foothills and Northern Hogback Belt.

Simpson (1948, p. $277-280$ ) proposed that the term "Wasatch" be discarded and proposed that the name San Jose formation be applied to these rocks, stating that they were deposited in an entirely different sedimentary basin from that of the type Wasatch in Wyoming and that. the age spans, although overlapping, were not the same for the two formations. The type locality of the San Jose formation was designated (Simpson, 1948, p. 281) as the badlands area in the drainage of San Jose Creek along and near the Continental Divide about 1 mile northwest of Regina, New Mexico. In the type region, which is the eastern part of the present area between Canyoncito de las Yeguas and Cuba, the San Jose consists of several major intergrading lithologic facies. These were recognized, but not mapped, by Simpson (1948, p. 367-374) who described them as the "sandstone facies of Yeguas Canyon", and the 
"Almagre" and "Largo" clay facies. The Almagre and Laxgo clay facies of Simpson are the beds containing the early Eocene Almagre and Largo vertebrate faunas named by Granger (1914, p. 205-207).

The San Jose formation of the present report is equivalent to the San Jose as defined by Simpson (1948). The lower contact is the same as that specified by Simpson (1948, p. 367; also, personal communication, 1959) in sec. 20, T. 24 N., R. 1 E., and this contact is believed to be nearly equivalent to the contact at the base of the sandstones capping Mesa de Cuba, and smaller mesas about 1 mile northwest of Cuba. The sandstones capping Mesa de Cuba were specified by Simpson (1948, p. 367) as being within the San Jose, thus the San Jose is essentially the same unit as the Wasatch mapped by Dane (1936) and by Wood and Northrop (1946). In the northeastern part of the area the base of the San Jose, as mapped for the present report, is approximately equivalent to the base of the Wasatch mapped by Dane (1948) in the northeastern part of the San Juan Basin.

Although the several lithologic facies of the San Jose are complexly interrelated they are mappable units. The present writer has distinguished four lithologic units and mapped them as members of the San Jose formation. Throughout the present area the lower part of the San Jose consists mostly of conglomeratic sandstone here named the Cuba Mesa rnember. In most of the southern two-thirds of the 
area the Cuba Mesa member is overlain by drab-colored, vasiegated shale with interbedded soft to hard sandstone here named the Regiria member of the San Jose formation. In the northern part of the area, the Regina member is overlain by a persistent unit of ledge-forming sandstone, and in the southern parts of T. $25 \mathrm{~N} ., \mathrm{R}, 1 \mathrm{E}$. and R. $1 \mathrm{~W}$. the Regina member intertongues with and grades laterally northward into a thick sequence of sandstone of which the persistent sandstone just described is a medial part. This thick sequence of sandstone is here named the Llaves (pronounced "Yah-ves") member of the San Jose formation. The upper half of the Llaves member grades southward and westward into a unit of rocks that consists mainly of red shale and soft sandstone but also contains lenticular ledge-forming sandstone. This unit, here named the Tapicitos member of the San Jose formation, lies above the persistent medial sandstone of the Llaves member on the northern part of the Tapicitos Plateau. These members are discussed more fully in succeeding pages of this report.

\section{Extent and Thickness}

The San Jose formation is the surface formation in most of the Central basin of the San Juan Basin, and is at the surface in most of the present area of investigation. The San Jose has been eroded deeply, and the differential resistance to erosion of its units of sandstone and shale produced a varied and, in places, rugged physiography. Because 
of this physiography, the thickness of the San Jose varien considerably throughout the area.

Along the Continental Divide at the northern edge of the Penistaja Cuestas sector the San Jose is estimated to be as much as $730-750$ feet thick, including the thickness of rocks forming the high mesa on the divide in the north-central part of T. 20 N., R. 4 W. This estimate is based partly on information from the Skelly Oil Co. No. 1 White well in sec. 8, T. 21 N., R. 4 W. However, in the broad washes that drain northward from the Continental Divide to Canyon Largo in this vicinity, all the San Jose except the lower part of the Regina member and the underlying Cuba Mesa member has been removed by erosion and the San Jose is only 200-400 feet thick as determined by logs of wells.

In the area north of Mesa de Cuba, the composite thickness of the San Jose is about 1, 430 feet along State Highway 44 between sec. 20, T. 21 N., R. 1 W. and the high mesa on the Continental Divide in sec. 28, T. 22 N., R. 2 W. In the broad alluvial valley of San Jose Creek near the southwest corner of T. 22 N., R. 1 W., the Sar Jose is estimated to be about 800 feet thick. In the San Pedro Foothills irs the SW $1 / 4$ sec. 2 and SW $1 / 4 \mathrm{sec}$ 3, T. 21 N., R. 1 W., the preserved part of the San Jose is about 865 feet thick. In the Yeguas Mesas region the San Jose is about 1,650 feet thick, as determined from composite sections. 
In the north-central part of the area, on the Tapicitos Plateau, the San Jose is $1,700-1,800$ feet thick, as determined from logs of wells in T. 26 N., R. 2 W. Farther south on the Tapicitos Plateau the base of the San Jose rises structurally and its upper beds have been eroded. The thickness of the San Jose in the southern part of T. 24 N., R. 2 W. is 1,300 feet or less.

In the Largo Plains more than half of the San Jose formation has been removed by erosion. The formation is thinnest along Canyon Largo and the western parts of its tributaries where the Cuba Mesa member is exposed because overlying beds have been stripped away by erosion. In the vicinity of Otero Ranch in the southwestern part of T. 24 N., R. $5 \mathrm{~W}$., the San Jose ranges in thickness from a little less than 200 feet to about 300 feet as determined from logs of wells. In the eastern part of the Largo Plains, in the northern part of T. 22 N., R. 3 W., the San Jose is $800-900$ feet thick.

\section{Cuba Mesa Member}

Throughout the present area of investigation, and elsewhere in the San Juan Basin, the lower part of the San Jose formation consists of conglomeratic, arkosic sandstone containing minor amounts of lenticular reddish, green, and gray shale. These rocks are here named the Cuba Mesa member of the San Jose formation for exposures on the upper slopes and top of Mesa de Cuba (known also by its anglicized form 
as Cuba Mesa) west of the Rio Puerco in T. 21 N., R. 1 W. A type stratigraphic section of the member was measured along State Highway 44 northwest of Cuba. The base of the section is in the NE $1 / 4 \mathrm{NW} 1 / 4$ sec. 20, and the section was measured westward across secs. 17, 8,7 , and 6, T. 21 N., R. 1 W., and secs. 1 and 2, T. 21 N., R. 2 W. The locality of measurement (no. 2) of the stratigraphic section is shown on the geologic map (Fig. 2), a detailed description is given at the end of this report, and the section is shown graphically in Figure 3. At the type locality along State Highway 44, the Cuba Mesa member is about 782 feet thick, and consists mainly of thick beds of buff and yellow, rusty-weathering, tangentially cross-bedded, arkosic, coarse-grained, conglomeratic sandstone. The lower part of the member contains several thin lenses of gray and purplish sandy shale. At about 490 feet above the base of the member is a unit of soft gray shale, about 55 feet thick, containing thin beds of soft sandstone. This shale thickens northward and merges laterally with the Regina member of the San Jose. South of State Highway 44 in sec. 8, T. 21 N., R. 1 W. the shale tongues out into the sandstone of the Cuba Mesa member. Another tongue of soft reddish and gray shale and soft sandstone, 83 feet thick, is about 640 feet above the base of the member. This tongue of the Regina member becomes sandier to the southwest, and wedges out into the Cuba Mesa member in sec. 11, T. 21 N., R. 2 W. The 
highest part of the Cuba Mesa member is a sandstone about 52 feet thick. Above the Cuba Mesa member is variegated shale and soft sandstone with several interbedded thick sandstones similar to those of the Cuba Mesa member, but mapped with the Regina member. These sandstones in the Regina member do not merge with the Cuba Mesa member and are separated from it by thick urits of shale of the Regina.

The Cuba Mesa member intertongues with the Regina member at other places in the area. Where the Cuba Mesa member consists of one unit of sandstone it is designated on the geologic map (Fig. 2) as Tsc. Where tongues are present, the pezsistent lower sandstone of the member is designated as $\mathrm{Ts}_{1}$, and the sandstone tongues of the Cuba Mesa member are designated successively as $T s_{2}$, etc., from lowest to highest.

The Cuba Mesa member is much thicker at the northern end of Mesa de Cuba than elsewhere in the area. To the southwest, in the vicinity of Arroyo Chiuilla, the upper part of the Cuba Mesa raenber is split into two tongues by westward-thickening tongues of reddish sandy shale (Tsr) which me rge laterally westward into the Regina member. The two upper sandstone tongues of the Cuba Mesa member wedge out westward into the Regina member near the southwestern corner of T. 21 N., R. 2 W. The lower part of the Cuba Mesa member persists to the west and is estimated to be about 230 feet thick in sec. 33 , T. 21 N., R. 2 W. West of here it is split thso two persistent units of 
sandstone separated by a thick unit of variegated shale mapped as a tongue of the Regina member. The lower sandstone unit of the Cuba Mesa member is about 50 feet thick and forms a low ledge or weak cliff above the Nacimiento formation. The upper unit of the Cuba Mesa forms a higher prominent escarpment of sandstone locally more than 60 feet thick. In sec, 25, T. 21 N., R. 5 W., the tongue of Regina shale wedges out and the two lower sandstones merge. From sec. 36, T. 21 N., R. 3 W. westward to sec. 34, T. 21 N., R. 4 W. a ledge forming, coarse-grained sandstone tongue of the Cuba Mesa member occurs interbedded in the lower part of the Regina member. In sec. 34, T. 21 N., R. $4 \mathrm{~W}$., this sandstone merges with the underlying main part of the Cuba Mesa member as the intervening tongue of the Regina member wedges out. West of here the tongue of shale of the Regina member is present again but wedges out in sec. 19, T. 21 N., R. 4 W., and westward from here the Cuba Mesa member is essentially one massive unit of cliff-forming, thick-bedded sandstone about 220 feet thick and containing very little shale except near the base where thin beds of shale are present locally. Lenticular beds of sandstone similar to those of the Cuba Mesa member occur in the lower part of the overlying Regina member, but they are separated from the Cuba Mesa member by gray and variegated shale of the Regina member. Northeastward from the type section at the northern end of 
Mesa de Cuba, the two upper sandstone tongues of the upper part of the Cuba Mesa member wedge out into the sandy variegated shale of the Regina member. The lower part of the Cuba Mesa member, about 490 feet thick, is split into two units of sandstone by a tongue of variegated shale of the Regina member. The tongue of the Regina member seems to thicken northeastward mainly as the result of lateral transition of the lower part of the upper tongue $\left(\mathrm{Tsc}_{2}\right)$ of the Cuba Mesa mernber into sandy shale. The two units of sandstone persist as far north as the SW $1 / 4 \mathrm{sec} .2, T, 21$ N., R. 1 W. where the lower sandstone ( $\mathrm{Tsc}_{1}$ ) contains several beds of shale and is 152 feet thick. The included tongue of the Regina member is about 200 feet thick, and the upper sandstone tongue $\left(\mathrm{Tsc}_{2}\right.$ ) of the Cuba Mesa member is only 37 feet thick. North of here the upper sandstone tongue of the Cuba Mesa member either wedges out, or is represented by thin, soft, lenticular sandstone included with the Regina member. The lower sandstone unit (Tsc ${ }_{1}$ ) of the Cuba Mesa persists to the north in the San Pedro Foothills and the Northern Hogback Belt. This unit, probably equivalent to only the lower 150-200 feet of the Cuba Mesa member at the type locality, is folded sharply in the San Pedro Foothills, and dips steeply west or is vertical. In the Northern Hogback Belt northward from sec. 20, T. 24 N., R. 1 W. the dip of the Cuba Mesa member becomes less steep because the outcrop is farther west of the monoclinal fold along the eastern margin of the area. 
In the eastern part of the area the thic kness of the Gizba Mess member varies because of the erosional and angular uncunformily at its base. This relationship is well exposed in the north wall of the canyon in the SW $1 / 4$ sec. $11, T .21$ N., R. 1 W., where the lower unit of sandstone of the Cuba Mesa member is about 180 feet thick at the bottom of the canyon, but updip at the top of the ridge, it is about half as thick. The thickness of the Cuba Mesa member is difficult to measure in the San Pedro Foothills and southern part of the Northern Hogback Belt, but in much of this region it is probabiy less than 150 feet thick.

In T. 24 N., R. 1 E., the Cuba Mesa member consists of three sandstone units separated by tongues of variegated shale of the Regina member. The two upper sandstones of the Cuba Mesa member $\left(\mathrm{Tsc}_{2}\right.$ and $\mathrm{Tsc}_{3}$ ) tongue out southward into the Regina member, with the upper tongue persisting farther south than the medial tongue. In the SW 1/4 NE 1/4 sec. 1, T. 25 N., R. 1 E., the persistent lower sandstone of the Cuba Mesa member is 27 feet thick. The lower shale tongue of the Regina is 51 feet thick; the medial sandstone tongue of the Cuba Mesa is 61 feet thick; the upper tongue of the Regina is 144 feet thick; and the upper sandstone tongue of the Cuba Mesa, containing thin shale beds, is 65 feet thick. Logs of wells in the vicinity of Arroyo Blanco indicate that the three sandstone tongues of the Cuba Mesa persist from some distance to the west in the subsurface, and then merge into 
a thick unit which is mainly sandstone. At the surface, in sec. 30 , T. 25 N., R. 1 E., the shale tongues of the Regina member become tian and the three sandstone tongues of the Cuba Mesa member merge into a unit which is mostly sandstone, and is 335 feet thick in the SW B/4 $\mathrm{NE} 1 / 4 \mathrm{sec} .18, \mathrm{~T} .25 \mathrm{~N} ., \mathrm{R} .1 \mathrm{E}$.

Along the eastern side of the Yeguas Mesas the Cuba Mesa member is overlain by the Llaves member consisting mainly of sandstone. The upper contact of the Cuba Mesa member is distinguishable, however, and it was mapped at the base of a unit of red, shaly sandstone and sandy shale which is the lower part of the Llaves member.

In the western part of the area the Cuba Mesa member crops out and forms massive cliffs along Canyon Largo and the western parts of its tributary canyons. On the basis of well logs, the average thickness of the Cuba Mesa member is estimated to be about 200 feet. The contact of the Cuba Mesa member and the underlying Nacimiento formation is not exposed in the western part of the area, but is exposed in Canyon Largo west of the Jicarilla Apache Indian Resveration. In most of the western part of the area the Cuba Mesa member is overlain by a thin unit of light-gray and variegated shale assigned to the Regina member. Northward, this lowest shale unit of the Regina is replaced gradually by sandstone, and along Tapicitos Creek in the southwestern part of T. 26 N., R. 5 W., the Cuba Mesa member is overlain by lenticular sandstone and shale that are equivalent to the lower shale unit of the Regina that 
rests on the Cuba Mesa member near Otero Ranch.

In the subsurface of most of the area, rocks assigned to the Cuba Mesa member are 200-250 feet thick. Locally, the lower part of the overlying Regina member contains thick lenticular sandstone similar to the Cuba Mesa member, but separated from it by units of shale. From the northern part of Mesa de Cuba, the thick upper tongues of sandstone of the Cuba Mesa member persist northwestward in the subsurface for 8-10 miles, but the sandstones are separated by westwardthickening tongues of shale of the Regina member, and the sandstones become thin and lenticular as they do at the surface. Where the sandstones seem to become lenticular, they are assigned to the Regina member (Fig. 7). In the subsurface of the northern part of the area, the Cuba Mesa member thickens northward as the result of merging with northwardthickening tongues of sandstone in the lower part of the Regina member as it does at the surface in the northeastern part of the area. Rocks assigned to the Cuba Mesa member in the subsurface of the northern part of the area (Fig. 5) are arbitrarily separated from the overlying Llaves member on the basis of their thickness (about 350 feet) which is comparable to the thickness of the Cuba Mesa member at the surface north of Canyoncito de las Yeguas (335 feet).

The sandstone of the Cuba Mesa member is coarse grained to very coarse grained, and contains granules, pebbles, and cobbles. The coarsest part of the Cuba Mesa member is in the northeastern part of 
the area. Most of the sand grains are angular to subangular, but the pebbles are commonly well rounded. The sand is mairly quartz, but fragments of feldspar and chert are common at all localities. Most of the pebbles are gray quartzite and quartz, but pebbles of granite, pink quartzite, and pink, red, gray, and buff chert are common also. A few pebbles of volcanic rock were observed. At most places the sandstone beds are tangentially cross bedded, and they seem to be stream-channel deposits. Silicified and carbonized logs are common in the sandstone at some places. The sediments of the Cuba Mesa. member were deposited probably by streams flowing to the west and southwest from highlands east and northeast of the present San Juan Basin as indicated by eastward coarsening of the sediments composing the rocks. These highlands must have been composed mainly of granite and metamorphic rocks of Precambrian age. The local thickening of the Cuba Mesa member at the type locality, and also a short distance west of the present area, may indicate source areas southeast of the basin also. The source areas for most of the Cuba Mesa mernber were probably the same as those for part of the Nacimiento formation, i. e. the Brazos and Sangre de Cristo uplifts and, perhaps, part of the San Juan dome. The numerous quartzite pebbles and cobbles in the northeastern part of the area could have been derived from the extensive Precambrian quartzite terranes of the Brazos uplift described by Just (1937). 
Resting conformably on the Cuba Mesa member in the southern. two-thirds of the area is a thick sequence of clay shale, siltstone, soft sandstone, and some ledge-forming, hard sandstone. These rocks are here named the Regina member of the San Jose formation for exposures near the town of Regina. The rocks are best exposed east of the Continental Divide in the badlands of the drainage basin of Arroyo Blanco in T. $24 \mathrm{~N}$, R. I E. and R. 1 W. The Regina member consists partly of the rocks described in Simpson's (1948, p. 371-374) stratigraphic sections 2 and 3 which are part of his composite typical section of the San Jose formation. Simpson measured these sections on the southern rim of Arroyo Blanco and near the Continental Divide in sec. 8, T. 23 N., R. 1 W. However, Simpson's stratigraphic sections (shown graphically on Fig. 3) do not include the lower part of the San Jose which he estimated (1948, p. 374 ) to be 200-300 feet below the base of his stratigraphic section 3. If the present writer's correlations are correct, the base of Simpson's lowest stratigraphic section may be 700-800 feet above the base of the San Jose. For this reason the type locality of the Regina member is here specified to be in the badlands and steep slopes to the west in the SW $1 / 4$ sec. 31, T. 25 N., R. 1 E. and the SE $1 / 4$ sec. 36, T. 25 N., R. I W. The locality of measurement $(3 \mathrm{~b})$ is shown on the geologic map (Fig. 2), a detailed description of the stratigraphic section is given at the end of thif Tepryt, and the section is shown graphically on Figure 3. 
At the type locality, the Regina rnember is abour 575 feer thick. and rests conformably on pebble- and cobble-bearing, coarse-grained, arkosic sandstone of the Cuba Mesa member. The Regina member consists mainly of soft beds of clay shale, siltstone, mudstone, shaly sandstone, and sandy shale, but contains also numerous beds of soft, fine - to coarse-grained, argillaceous sandstone, and a few beds of resistant congloneratic, arkosic, cliff-forming sandstone. Most of the shaly beds are light gray, tan, or olive gray, but bands of dull purple, maroon, and some green shale are common and are typical of the member. Pale-red to maroon shale is most common in the upper one-fourth of the member throughout the region. Sandstones range in color from white to buff, gray, and brown. The Regina member as mapped by the write $r$ includes the "Almagre facias" of Simpson (1948, p. 368) and the red shale and sandstone along the Continental Divide north of Regina that were specified by Simpson (1948, p. 369-371) to be the lower part of the "Largo facies". No persistent, mappable lithologic boundary was found to separate the Almagre beds from the lower part of the Largo beds. At the type locality, the Regina me mber contains, near the middle and near the top, several beds of resistant conglomeratic sandstone. These sandstones are tongues of the Llaves member and they wedge out to the south or become soft discontinuous lenses enclosed in shale of the Regina member. To the north, the sandstone beds thicken as the intervening shale units of the Regina thin, or pass laterally into shaly sandstone. 
North of sec. 19, T. 25 N., R. 1 E., the stratigraphic interval equivalent to the Regina member is nearly all sandstone or shaly sandstone which are assigned to the Llaves member. This transitional relationship was first recognized by Dane (1946) who described it generally, but did not subdivide the rocks he assigned to the Wasatch.

At the type locality, the Regina member is overlain by a ledgeforming conglome ratic sandstone of the Llaves member. Southwest of the type locality, this sandstone and several stratigraphically higher beds of the Llaves member wedge out to the south between southwardthickening tongues of the Regina member. Because of this relation-ship, the upper contact of the Regina member is stratigraphically higher to the south than it is at the type locality. The highest thick persistent sandstone of the Llaves member on the ridge above the type locality of the Regina is believed to be at about the same stratigraphic position as the persistent medial sandstone unit of the Llaves member which rests on the Regina member in the northern part of the Tapicitos Plateau. Thick, ledge-forming, lenticular beds of sandstone interbedded with red and variegated shale occur near the top of the Regina member at places along the Continental Divide nearly as far south as Cuba and also in the southern part of the Tapicitos Plateau south of Canyon Largo. The stratigraphic position of these sandstones is judged to be below that of the persistent medial sandstone unit of the Llaves member. The highest thick sandstone capping the mesa on the Continental Divide north of Regina in secs. 16 
and $21, T .23 \mathrm{~N} ., \mathrm{R}, 1 \mathrm{~W}$. is probably equivalent to the medial sandstone of the Llaves member. The highest beds of persistent thick sandstone on the narrow mesas along the Continental Divide in secs. 21 and 28, T. 22 N., R. 2 W. also are probably equivalent to the medial sandstone of the Llaves member.

The lithology of the Regina member at the type locality is typical of the member throughout the area. Most of the member is composed of drab-colored, variegated shaly beds of clay, siltstone, and mudstone with intercalated soft, argillaceous sandstone. Beds of thicker, more persistent conglomeratic sandstone interbedded in thick shale are fairly common in the lower third of the member as well as in the upper part. In the subsurface of the northern part of the area, the Regina member intertongues with and grades northward into the lower part of the Llaves member, as it does at the surface in the northeastern part of the area. The lithology of parts of the Regina member in the San Pedro Foothills is not typical of the member elsewhere. Beds of greenish-gray clay shale and siltstone similar to Cretaceous rocks are interbedded with thin conglome ratic sandstones containing nume rous pebbles of sandstone, shale, and limestone. Cretaceous shark teeth, as well as Tertiary mammal teeth occur in the se beds. It is believed that much of the sedimentary detritus composing the se beds was eroded from Cretaceous and oider sedimentary rocks of the Nacimiento uplift which seems te have been tectonically active during deposition of the Regina member. The 
uppermost beds of the Regina member, predervet at a fen places i the San Pedro Foothills, overlap the Cuba Mesa me nuber and alsu socks as old as the Mesaverde formation, and contain lime stone and sandstone pebbles similar to those of the Triassic rocks exposed on the Nacimiento uplift. The stratigraphic relations of the se overlapping rocks are discussed later.

Because of intertonguing relationships of the Regina member with the Cuba Mesa and Llaves members, and because the San Jose formation has been eroded deeply, the thickness of the Regina member varies greatly in different parts of the area. In the subsurface of the northern part of the Tapicitos Plateau the Regina is about 1,040 feet thick at the Humble Oil and Refining Co. No. 1 Jicarilla $M$ well in sec. 23, T. $25 \mathrm{~N} .$, R. $4 \mathrm{~W}$. To the northeast most of the stratigraphic interval of the Regina is replaced laterally by thick sandstone bede of the Llaves member (Fig. 5).

In the southern part of the Northern Hogback Belt, and in the San Pedro Foothills, the Regina member has been eroded deeply. The preserved lower part of the member ranges from a few feet to 800 feet in thickness. In the high hills just west of the Continental Divide at the Abraham No. 1 Abraham well in sec. 17, T. 24 N., R. 1 W. , most of the Regina member is preserved and it is about 1, 640 feet thick. This is almost three times the thickness of the member at the type locality. The southward thickening is, in part, the result of the southward 
stratigraphic rise of the upper contact of the Regina member owing to the wedging-out of sandstone tongues of the overlying Llaves member. However, the thickening is probably due mainly to southward thickening of rocks within the Regina member.

Along the Continental Divide in most of the Penistaja Cuestas sector the part of the member preserved is no more than 500-600 feet thick. In the Largo Plains the preserved part of the Regina member is only 100-300 feet thick near the western edge of the area, but the member becomes thicker northward and eastward as the land surface rises toward the Tapicitos Plateau, and the Regina member is about 1,100 feet thick at the U. S. Smelting, Mining, and Refining Co. No. 2-2 Jicarilla 137 well in sec. 2, T. 23 N., R. 4 W.

\section{Llaves Member}

In the Yeguas Mesas, in the drainage of Canyoncito de las Yeguas, the San Jose formation is composed mainly of resistant, arkosic, conglomeratic sandstone which forms massive ledges. The sandstone contains also thin beds of red and variegated shale and shaly sandstone. This unit is here named the Llaves (pronounced Yah'-ves) member of the San Jose formation for exposures near the mouth of Canyoncito de las Yeguas about 1-1/4 miles northwest of Llaves Post Office. A stratigraphic section of the lower part of the Llaves member was measured up the eastward-projecting spur of the mesa in the north half of sec. 18 , 
T. 25 N., R. 1 E. (locality 4 on Fig. 2). Here the lower part of the Llaves member is almost 700 feet thick and rests on sandstone of the Cuba Mesa member about 335 feet thick. Because the Llaves beds dip west, stratigraphically higher beds are preserved farther west. The highest beds measured on the mesa near the mouth of Canyoncito de las Yeguas are believed to be stratigraphically slightly lower than a thick sandstone exposed at the base of the north wall of the canyon in the SW $1 / 4$ sec. $4, T, 25 \mathrm{~N},, \mathrm{R}, 1 \mathrm{~W}$. In this section, and in sec. $33, \mathrm{~T}, 26 \mathrm{~N}$. , R. I W., (locality 5 on Fig. 2) approximately 450 feet of upper beds of the Llaves member are present. These rocks consist of yellow and buff arkosic conglomeratic sandstone with red sandstone and some red and gray shale interbedded. Similar beds, estimated to be about 150 feet thick, are present farther west near the Continental Divide; thus the Llaves member is about 1, 300 feet thick in the Yeguas Mesas type area. A description of the stratigraphic sections is given at the end of this report and the stratim graphic section of the lower part of the member is shown graphically on Figure 3.

The Llaves member is composed mostly of very coarse grained, conglomeratic sandstone. The sand is angular to subangular and consists mainly of quartz and quartzite grains, but fragments of pink to gray feldspar are abundant. Most beds contain pebbles and cobbles, and some beds are very gravelly. The pebbles and cobbles are rounded and stream worn, and most of them are white to gray and purplish metaquartzite. At some 
places, pebbles and cobbles of granite are common, and a few fragments of gneiss and schist were observed. Pebbles of red and gray chert, volcanic rock, sandstone, and shale also were observed. The sandstones are highly cross bedded and range in thickness from less than 10 feet to almost 100 feet. The sandstones are characteristically light tan, buff, or gray, and commonly weather to a brownish hue which has led to their being described as copper-colored (Dane, 1946; Simpson, 1948, p. 366).

The Llaves member contains nume rous thin beds of clay shale and mudstone that are predominantly maroon, but are also green and gray. Also common are thin beds of red sandstone, sandy shale, and shaly sandstone. At places, especially in the upper 500 feet of the member, rocks of this type form units as much as 50-60 feet thick. Reddish sandstone with red shaly partings forms the basal unit, 85 feet thick, of the Llaves member on the east side of the Yeguas Mesas.

As previously described, the lower part of the Llaves member tongues out to the south into the Regina member at the surface and in the subsurface. A persistent unit of sandstone containing a few beds of shale at places, and ranging in thickness from about 50 feet to 100 feet or more, extends southward and westward from the main body of Llaves sandstone and rests on the Regina member in much of the northern part of the area. This persistent sandstone unit is equivalent to beds above the top of the stratigraphic section measured at the mouth of Canyoncito de las Yeguas. Thus, the persistent unit is about 700-800 feet above the base of the Llaves 
member and stratigraphically near the middle of the member. Remnants of sandstone believed to be equivalent to the persistent medial sandstone of the Llaves member cap high isolated buttes on the Continental Divide north of Regina, and on and near the divide in the southern part of T. 22 N., R. 2 W.

The upper part of the Llaves member, above the position of the persistent medial sandstone, occurs only in the Yeguas Mesas. The beds of the upper part of the Llaves thin to the south and west, and are split by tongues of red shale which are as signed to the Tapicitos member of the San Jose formation. The details of the intertonguing in the western part of T. 25 N., R. 1 W. are complex and the relationships shown on the geologic map have been generalized slightly. The units mapped as tongues of the Llaves member are sandstone beds which are persistent and can be traced into the massive sequence of Llaves sandstones. The units mapped as tongues of the Tapicitos me mber are characterized by containing much red shale. However, they also contain lenticular sandstone beds similar to those of the Llaves member, but not merging into it. Thick beds of sandstone which seem to have been lenticular stream-channel deposits cap several mesas and buttes on the Continental Divide in T. 25 N., R. $1 \mathrm{~W}$. and farther to the northwest. Some of these sandstone beds are stratigraphically equivalent to sandstone beds in the Llaves member but do not connect now with the Llaves. Therefore, these isolated sandstones were mapped with the Tapicitos member. A similar philosophy 
of mapping was applied in delineating the Llaves and Tapicitos members along the western side of the Yeguas Mesas.

The lower part of the Llaves member persists in the subsurface across the north-central part of the area where it is $300-700$ feet thick. The lower part of the Llaves member tongues out southward into the Regina member in the subsurface in a complex manner similar to that at the surface in the eastern part of the area. North of the present area the lower and upper parts of the Llaves member tongue out to the north into a sequence of shale similar in lithology and stratigraphic position to the Regina member. The medial sandstone and the lower part of the Llaves member persist to the northwest across the Central basin.

The coarse-grained quartzose and arkosic sandstones of the lilaves member appear to be first-cycle sediments derived from a terrane of Precambrian granite and metamorphic rocks. The cobbles and pebbles of the Llaves me mber are mostly bluish and gray metaquartzite similar to the widespread metaquartzites of the Brazos uplift (Just, 1937). The granite pebbles and cobbles are dissimilar to the dense, reddish brown granite of the Nacimiento uplift but are similar to granite occurring in the Brazos uplift and western side of the Sangre de Cristo uplift from which they probably were derived. The red sandstone and shale of the Llaves are similar to rocks of the Cutler formation (Permian) and Chinle formation (Triassic) which probably were exposed in the Brazos uplift and probably in the Nacimiento uplift at this time. Much of the red-colored 
sediment is probably second-cycle material derived frorn the Permian and Triassic rocks of the uplifts bounding the basin.

As determined by reconnaissance investigation in other parts of the basin, the Llaves member appears to be a large, narrow, northwest-trending fan of coarse detritus dumped into the structurally deepest part of the Central basin by streams flowing northwestward from a Precambrian terrane east of the basin in the position of the present Brazos and Sangre de Cristo uplifts. The Nacimiento uplift may have stood as low hills shedding sediment eroded from Paleozoic and Mesozoic rocks exposed on the uplift. The position of the uplift probably deflected streams flowing westward so that some of them were directed around the northern end of the uplift and into the basin neax Canyoncito de las Yeguas. The northeastward thinning of the Regina member of the San Jose formation across T. 24 N., R. 1 W. probably indicates that, at the time of deposition of stratigraphically equivalent rocks of the lower part of the Llaves member, the monocline on the western side of the French Mesa-Gallina uplift was being formed. The large northwest-trending anticlines of the Archuleta anticlinorium may have stood as topographic highs. If this is so, the westward-flowing streams carrying coarse detritus from the Brazos-Sangre de Cristo region across the Chama basin probably were channeled around the southern part of the Archuleta anticlinorium, and entered the San Juan Basin near the position of Canyoncito de las Yeguas. Detritus eroded 
from sedimentary rocks on the Nacimiento uplift and Chaco lope were deposited in the southern part of the basin as the Regina member and interfingered with the southern edge of coarse material of the Llaves member. Detritus, probably from the San Juan dome, was deposited as a facies similar to the Regina member, but on the northern side of the Llaves fan north of the present area of investigation.

\section{Tapicitos Member}

Above the persistent medial sandstone of the Llaves member on the northern part of the Tapicitos Plateau is a sequence of maroon and variegated shale with intercalated thin to thick lenticular sandstone beds that are (along with stratigraphically equivalent beds of the upper part of the Llaves member) the youngest rocks of the San Jose formation. This unit is here named the Tapicitos member of the San Jose formation for exposures in the upper drainage of Tapicitos Creek, and near Tapicitos Post Office. The member is well exposed also in the upper drainage of Gavilan Creek above Gavilan, in the cliffs and badlands just west of the Continental Divide in the eastern part of T, $25 \mathrm{~N}$. R. $2 \mathrm{~W}$. and in the western part of T. 25 N., R. 1 W.

\section{Exposures along State Highway 95 east of upper Gavilan Creek} in secs. 1,2 , and $11, T .25$ N., R. 2 W. may be considered as typical of the Tapicitos member although a detailed stratigraphic section was not measured. Here the $\mathrm{T}$ apicitos member rest on the persistent medial 
sandstone of the Llaves member and is estimated to be about 450 feet thick. The lower part of the Tapicitos member is about 300 feet thici. and consists mistly of slope-forming pale-red to maroon clay shaie, siltstone, and mudstone with some variegated white, gray, and parpliah beds. The shale contains lenticular, soft, white and yellow sandstone and some beds of hard gray sandstone. Above this is s tonglie of the Llaves member consisting of several beds of hard coarse-grained sandstoke of varied thickness. This sandstone tongue, 20-30 feet thick, holds up cliffs and small benches, and farther west the tongue changes laterally into lenticular beds of sandstone included in the Tapicitos member. Above this is more slope-forming red clay shale, siltstone and interbedded sandy shale and thin sandstone, all estimated to be about 120 feet thick. The Tapicitos member is overlain by a tongue of thick cliff-forming sandstone of the Llaves member which caps the highest mesas on the Continental Divide to the north. The Tapicitos member, as here defined, is equiva lent to most of the "Largo facies" of Simpson (1948, p. 369) although the lowest beds of the Largo facies are included in the Regina member. A stratigraphic section describing the Largo facies was measured by Simpson (1948, p. 370-371) at a locality not precisely specified near the head of the north branch of Oso Arroyo, in the southwestern part of T. 25 N., R. I W. A description of this section is included at the end of this report. The base of Simpson's stratigraphic section is prubably about $25-50$ feet above the base of the Tapicitos member, and the highest beds described 
are probably nearly equivalent stratigraphically to the tongue of the Llaves member separating the lower and upper parts of the Tapicitos member north of Simpson's section.

The Tapicitos member on the Tapicitos Plateau consists mainly of reddish to maroon shale, but at all places containsbeds of thin to thick, lenticular sandstone. Some of the sandstone beds are persistent for several miles along the outcrop and locally form strong cliffs. These sandstones are brown to yellowish buff, coarse grained and locally conglome ratic, cross bedded, and are lithologically similar to sandstone of the Llaves member. Other sandstone beds are white, buff, or red; fine to coarse grained and argillaceous; thin and nonpersistent; and are lithologically similar to some sandstones of the Regina me mber. The thickness of the Tapicitos member varies considerably because its upper surface has been deeply eroded. The maximum thickness is about 500 feet, and at most places, the preserved part of the member is no more than 200-300 feet thick.

The Tapicitos member tongues out eastward into the upper part of the Llaves member in the western part of the Yeguas Mesas. Thick tongues of red shale of the Tapicitos member grade laterally into red shaly sandstone, or are replaced laterally by yellowish-buff sandstone of the Llaves member. Some of the units of reddish sandstone and sandy shale can be traced for considerable distances within the Llaves member; however, they are mapped arbitrarily with the Llaves where they are 
predominantly sandstone and sandy shale.

The Tapicitos member seems to have been deposited as floodplain and stream-channel deposits. The upper part of the Llaves member is probably a part of the main fan of coarse detritus dumped where major streams flowing from the highlands at the east entered the San Juan Basin. The competence of these streams was less than that of the stroams which deposited the lower and middle parts of the Llaves member, or the neighboring highlands were worn down and did not contribute as much coarse sediment as they had earlier, because the extent of the upper part of the Llaves member is small compared to the extent of the lower part. The thick, coarse-grained, lenticular sandstones of the Tapicitos member were probably deposited in the main channels of streams flowing westward from the fan. Because the Tapicitos member and its probable equivalents farther to the north and northwest are preserved only in limited areas in the axial part of the Central basin, it is impossible to infer more than a general picture of its distribution and facies relationships. Probably the Central basin was tectonically quiescent and was filled by sediments of the Tapicitos member which lapped out across the folded margins of the basin onto the surrounding platforms and slopes. This seems to be indicated by the overlapping relations of rocks assigned to the upper part of the Regina member in the San Pedro Foothills near La Jara Creek and in the northeastern part of T, 21 N., R. 1 W. A similar overlap of Cretaceous xocks by coarse sandstone and red shale 
of the upper part of the San Jose occurs on the Hogback monocline in the northwestern part of the basin (Baltz, 1953, p. 52-53).

The environments of deposition of the drab shales which characterize the Regina member, and the maroon shales which characterize the Tapicitos member were discussed briefly by Simpson (1948) who referred to these rocks as the "Almagre facies" and "Largo facies", respectively. Simpson quotes the conclusions of Van Houten (1945, p. 442-444) concerning the interpretation of alternate banding of red and pale clays common in continental deposits of the early Tertiary. Van Houten has concluded that the gray and drab-colored sediments were deposited in swampy lowland areas, whereas red beds were deposited under drier conditions on savannahs. Simpson (1948, p. 380-382) infers that the Almagre facies (included in the Regina member of the present report) was deposited in a swampy environment, and that the Largo facies (included in the uppermost part of the Regina member, and in the Tapicitos member of the present repovt) was deposited in savannah-like conditions. Although this inference seems to be correct in the light of ecological evidence deduced from the faunas of the two facies, the present writer believes that the main reason for the difference in color of the lower and upper parts of the San Jose is the difference in color of the older sedimentary rocks from which the Eocene sediments were derived. The Cretaceous rocks which seem to have provided much of the sediment of the Regina member 
are drab-colored rocks which were deposited in marine environemnts, or in swampy lowland areas during Cretaceous time. Sediments eroded from these rocks.were deposited in the San Juan Basin after having been transported for only moderately short distances and were probably buried rapidly, thus retaining much of their original character. Red beda of Jurassic, Triassic, and Permian age which were exposed after stripping of.Cretaceous rocks from the uplifts surrounding the Sen Juan Basin were already oxidized, and sediments derived from these rocks were deposited as second- or third-cycle red beds of the upper part of the Regina member and the Tapicitos member. The lithology of some beds of the Llaves and Tapicitos members is strikingly similar to that of the Chinle and Cutler formations.

\section{Contacts}

The San Jose formation rests on the Nacimiento formation with erosional and angular unconformity. In the subsurface the Cuba Mesa member truncates success ively lower beds of the Nacimiento. formation from north to south. The angularity between the Cuba Mesa and Nacimiento is less than $1^{\circ}$ regionally, inasmuch as only about 600 feet of rocks are truncated in more than 30 miles. As previously discussed, part of the thinning of the Nacimiento seems to take place within the formation, but the study of the subsurface stratigraphy shows that upper beds of the Nacimiento are cut out successively from north to south. 
On the eastern side of the Central basin, the considerable variation in thickness of the Nacimiento occurs in short distances and the angular unconformity at the base of the San Jose represents relatively sharp local folding rather than broad regional tilting. The excellent exposure of the angular unconformity between the Cuba Mesa member and the Nacimiento formation in sec. 11, T, 21 N., R. 1 W. has been described earlier. At this locality the difference between the angles of dip of these units is about $30^{\circ}$. In this same vicinity, thin remnants of gray, olive-green, and maroon shale, red sandstone containing limestone and chert pebbles, and white to gray sandstone and coaly shale, occurring at the tops of the narrow divides between the deep canyons, are tentatively assigned to the Regina member. These rocks dip west at about $10^{\circ}$ and are overlain with erosional unconformity by high-level terrace deposits of boulder conglomerate of probable late Tertiary or Quaternary age. The best-exposed and thickest remnant of the shales and sandstones is at the top of a steep cliff in the south-central part of sec. 2, T. 21 N., R. 1 W, where they rest with marked angular unconformity on overturned beds of the Nacimiento formation, Ojo Alamo sandstone, Fruitland and Kirt land formations, and Lewis shale. At this place, the lowest part of the overlapping sequence is a local, gray conglomeratic channel sandstone. Above this are coaly shale and brown, gray, and green shale and thin buff sandstone. The entire sequence is about 130 feet 
thick. These rocks are cut out entirely a short distance to the west by a channel deposit of salmon-pink boulder gravel of the overlying Tertiary or Quaternary terrace gravel. Remnants of reddish shale and sandstone assigned to the Regina member rest on the Lewis shale to the east, and remnants are preserved at the tops of narrow ridges in sec. $11, T .21 \mathrm{~N} .$, R. $1 \mathrm{~W}$. The stratigraphic position of these overlapping rocks was not determined with certainty, but they are lithologically most similar to the upper part of the Regina member of the San Jose, or to parts of the Tapicitos member. The overlapping rocks were assigned tentatively to the upper part of the Regina member. Also, they are similar to faulted rocks assigned to the Regina member and resting unconformably on Lewis shale in sec. 23, T. 22 N., R. 1 W. These rocks appear to have overlapped the Cuba Mesa member of the San Jose as well as other rocks. The overlapping rocks at this locality contain teeth of Hyracotherium ("Eohippus") (G. G. Simpson, personal communication, 1959) and thus are definitely of Eocene age. These rocks are topographically lower than the overlapping rocks farther south and appear to have been folded or faulted down after their deposition.

It is of interest to note that cross section "A-A" of Gardnex (1910, pl. 2) is drawn through the vicinity of the overlapping Regina rocks in sec. 2, T. 21 N., R. 1 W., and he indicates that the "Wasatch" rests with pronounced angular unconformity on Nacimiento, "Laramie", Lewis, Mesaverde, and Mancos rocks, and is overlain by "Recent 
Bowlders". Gardner $(1910$, p. 721$)$ concluded that the "Wasatch" overlapped older rocks and rested against the Precambrian at the foot of San Pedro Mountain. Later workers (Reniek, 1931, p. 54-55; Dane, 1946, fig. 2; Wood and Northrop, 1946; Simpson, 1948, p. 375-376) have shown that Gardner's $(1909,1910)$ mapping of the base of the "Wasatch" along the front of San Pedro Mountain is largely incorrect. However, the observations of R. L. Koogle (personal communication) and the present writer have confirmed that Gardner was at least partly right, and that part of the San Jose does overlap older rocks at a few places along the front of San Pedro Mountain. Because the Tertiary or Quaternary gravels conceal underlying rocks, it was not determined whether the remnants of the Regina lap onto the Precambrian granite of San Pedro Mountain as stated by Gardner. There is no abundance of fragments of Precambrian rock in the Regina beds that would indicate that the Precambrian was exposed at this time, and the present writer believes that the Precambrian core of the Nacimiento uplift was not exposed to erosion until after the deposition of the San Jose formation, In this connection, Church and Hack (1939) found remnants of a peculiar and distinctive chert resting on Precambrian rocks on San Pedro Mountain. This chert was correlated with a unit of chert lying beneath the Abiquiu volcanic tuff of Smith (1938) on Pedernal Peak at the northeastern side of the Nacimiento uplift. This chert was named the Pedernal chert member of the Abiquiu tuff by Church and Hack $(1939$, p. 618$)$ and was said to rest on a profound surface of 
erosion. The Abiquiu'rests on the El Rito formation (of Smith, 1938) of Eocene(?) age, is older than the Santa Fe formation (or group) of Miocene, Pliocene, and Pleistocene age, and may be as old as Oligocene. This would seem to indicate that Precambrian rocks of the Nacimiento uplift were exposed to erosion in Eocene or Oligocene time. However, it is possible that part of the Pede rnal chert is a silicified zone caused by deposition of silica leached from the Abiquiu tuff by groundwater and deposited at the base of the formation, and thus not necessarily a stratigraphic unit. Also, the description of the Pedernal chert and associated limestone resting on Precambrian rocks at scattered outcrops on San Pedro Mountain (Church and Hack, 1939, p. 620) is similar to the description of the chertified upper part of the Arroyo Penasco formation of Mississippian age (Fitzsimmons, Armstrong, and Gordon, 1956) which rests on the Precambrian at places in the Nacimiento uplift. Fitzsimmons, Armstrong, and Gordon (1956) and Hutson (1958, p. 9) found the Arroyo Penasco to be present near the northern end of San Pedro Mountain. At any rate, the stratigraphic evidence cannot be said to show conclusively that Precambrian rocks were exposed to erosion on the Nacimiento uplift during deposition of the San Jose formation, and the extensive erosion surface cut on Precambrian rocks on the Nacimiento uplift may have been developed in middle and late Tertiary time during formation of the Rio Grande trough. 
Age and Correlation

The San Jose formation of the present area is of early Eocene age, and according to Simpson (1948, p. $382-383$ ) the San Jose was deposited probably during early and middle Wasatchian time. Correlation of the San Jose of the type region of the present report with rocks called "Wasatch" in other parts of the San Juan Basin is tentai

tive. There is no doubt that the large part of the San Jose correlates with most of the "Wasatch" of other investigators; the main problem lies in the definition of the lower boundary of the formation outside the present area. The upper part of the Nacimiento formation at places contains conglome ratic arkosic sandstone similar to that of the Cuba Mesa member of the San Jose, and there is a possibility of confusing these rocks with sandstone beds of the Cuba Mesa member of the San Jose which rest unconformably on the Nacimiento.

The contact of the San Jose is easily traced in the southern part of the area and it was traced by the writer to the west side of the drainage divide west of Lybrooks (Fig. 1) in T. 23 N., R. 7 W., west of the area of the present report. The contact of the Nacimiento and San Jose was traced northward from Lybrooks to the vicinity of Cedar Hill, New Mexico, on the Animas River near the Colorado-New Mexico boundary by $\mathbf{P}$. T. Hayes (personal communication; see Dane and Bachman, 1957). This contact is very similar in general, but not 
in all details, to the base of the "Wasatch" mapped by Reeside (1924, pl. 1). In the vicinity of Cedar Hill and to the north in Colorado, the Nacimiento formation contains thick beds of coarse-grained andstone similar to the basal part of the San Jose. The base of the San Jose (Wasatch) was mapped by Reeside (1924, p. $40-41$ ) as the base of a thick, persistent sandstone in this area. Reeside found that the sandstone beds of the Nacimiento (Torrejon) formation are lenticular. The basal sandstone of the "Wasatch" in the vicinity of the Colorado-New Mexico boundary near Cedar Hill was said by Reeside to be equivalent to the Tiffany beds. However, as pointed out by Barnes (1953), it is impossible to precisely trace the contact northward to the quarries in the southern part of the H-D Hills in Colorado where the Tiffany fossils were found. Barnes expressed uncertainty about correlating the basal rocks of the" Wasatch" from the Animas River to the southern part of the H-D Hills; however, reconnaissance examination of this area by R. B. O'Sullivan and the writer determined that Barnes' "bed d" above the Tiffany beds in the southern part of the H-D Hills is equivalent, or nearly so, to "bed a" of Barnes which is the base of the "Wasatch" as mapped by Reeside $(1924, \mathrm{pl} .1)$ in the canyon of Animas River near the New Mexico-Colorado boundary. If this is correct, the San Jose formation is probably entirely Eocene in the nortbwestern part of the basin as it is in the present area of investigation. It is believed as poin out earliex in this report that the 
Tiffany beds probably should be included in the stratigraphic interval of the Nacimiento and Animas formations.

The basal part of the San Jose is conglome ratic arkosic sandstone throughout the San Juan Basin, except locally south of Durango, Colorado (Baltz, 1953, p. 61-62; Reeside, 1924, p. 40-41). This sandstone, or zone of sandstones, in most of the basin is probably equivalent to the Cuba Mesa member. The Regina member is present wcrose much of the central part of the basin as far west as the lower part of Canyon Largo.

The Regina member tongues out northward into the lower part of the Llaves member which is present in a northwest-trending belt from the vicinity of Canyoncito de las Yeguas, to the Mesa Mountains and southern part of Bridge Timber Mountain in Colorado. The bold cliffs of sandstone of the San Jose east of Aztec, and in the canyon of the Animas River on both sides of the Colorado-New Mexico boundary are composed of rocks probably equivalent to both the Cuba Mesa and Llaves members. These racks were referred to as the "heavy sandstone (Yeguas Canyon) facies" by the writer in a previous report (Baltz, 1953, p. 61-63, 92).

In the northern third of the Central basin in New Mexico and Colorado, a sequence which is mainly shale is stratigraphically equiva lent to the lower part of the Llaves member and to the Regina member. This northern unit has not been studied in detail, or named, but it 
seems to persist across the northern part of the Central basir. where it is underlain at most places by sandstone equivalent to the Cuba Mesa member. Rocks probably, or nearly, equivalent to the persistent medial sandstone of the Llaves member also are present above the northern shale unit at many places in the northern part of the basin. The sandstones capping Carracas Mesa east of the San Juan River near the Colorado-New Mexico boundary, and the highest sandstones capping the Mesa Mountains and H-D Hills, respectively, southeast and east of Durango, Colorado, may also be equivalent to the medial sandstone of the Llaves member. A persistent sandstone occurring near the top of Bridge Timber Mountain southwest of Durango may also be equivalent to the medial sandstone of the Llaves member. This sandstone and the overlying rocks which are predominantly red sale overlap Cretaceous rocks on the Hogback monocline.

The Tapicitos member is present over a large region on the Tapicitos Plateau in the east-central part of the Central basin, and the highest red beds of the San Jose on Bridge Timber Mountain in the northwest part of the basin probably are equivalent to the Tapicitos member.

In view of the rapid variations in lithology of the continental deposits of the San Jose, and the unconformities known to occur at various places. correlations of the me mbers should be considered only as tentative. Detailed mapping in parts of the basin will be necessary to determine 
with assurance the distribution and relations of all the members $c$ ae San Jose formation.

The possible correlation of the San Jose with the Blanco B.sin formation of the southern San Juan Mountains has been suggested. Cxos and Larsen (1935, p. 48-50) named and described this formation composed of arkosic conglome rate, sandstone, and shale, and assigned a questionable Oligocene age to it because of its istratigraphic position unconformably above the rocks ranging in age from Tertiary (Animas formation) to Precatmbrian, and below volcanic rocks of questionable Miocene age. Cross and Larsen correlated the Blanco Basin with the Telluride conglomerate of the western Sar Juan Mountains. Several writers have suggested that the Blanco Basin is equivalent to the San Jове (or Wasatch) formation (Baltz, 1953, p. 76-77; Van Houten, 1957; Kelley, 1957, p. 157; Muehlberger. and others, 1960, p. 99). Although the obvious lithologic similarity makes this correlation attractive, no fossils have been reported from the Blanco Basin formation, and structural considerations cast some duubt on the correlation. The Blanco Basin in the San Juan Mountains is at higher altitude than the San Jose formation in the San Juan Basin, and this may indicate that it is younger than the San Jose. The Blanco Basin formation may have been deposited in an area where rocks equivalent to the San Jose were never present, or from which they had been stripped by erosion before deposition of the Blanco Basin. On the other 
hand, some of the younger rocks of the San Jose overlap older Tertiary and Cretaceous rocks at places on the Hogback monocline and at the foot of San Pedro Mountain, probably indicating that the Central basin was filled with sediments in Eocene time, and the youngest sediments of the San Jose. were deposited outside the margins of the Central basin as well. The overlapping rocks of the San Jose are tilted slightly, indicating that depression of the basin, or elevation of surrounding uplifts (or both) occurred after deposition of the latest San Jose rocks. If the Blanco Basin is equivalent to latest San Jose rocks, this postSan Jose folding would expiain the difference in altitude of the two formations.

Similar arguments may be applied to the correlation of the San Jose formation and the El Rito formation (of Smith, 1938) of probable Eocene age, which occurs in the Brazos uplift and northeastern part of the Nacimiento uplift. Muehlberger and others $(1960$, p. 99) have stated that the Blanco Basin formation interfingers with and grades southward into the El Rito formation. There is no doubt that the coarse debxis of the El Rito was deposited by streams flowing southwestward and westward from Precambrian terranes of the Brazos uplift, and the north-south distribution of the coarse conglonierates of the El Rito is similar to the north-south distribution of the conglomeratic sandstones of the Llaves member of the San Jose formation. Both of these factors and the lithologic similarity favor correlation of the San Jose and E1 Rito 
formations. However, the El Rito is at higher altitude (except wher it has been faulted or tilted down toward the Rio Grande trough) than the San Jose formation.

The Blanco Basin and El Rito formations probably are equivalent to the youngest rocks of the San Jose formation, ox possibly to slightly younger rocks that were part of the same depositional sequence, but are not preserved in the San Juan Basin. The Blanco Basin and El Rito formations probably were deposited during the closing phases of Eocene sedimentation when the basin of deposition was nearly filled and the sediments began to lap onto the worn-down highlands which were the source terranes of older Eocene sediments. The last-deposited sediments may have been as young as Oligocene.

The San Jose formation is equivalent, in part at least, to other early Tertiary rocks in the southern Rocky Mountain region. The Cuchara and Huerfano formations in the northern Raton basin east of the Sangre de Cristo Mountains are early and middle Eocene in age (Johnson and Wood, 1956) and their facies is similar to that of the San Jose formation. The Galisteo formation of the Galisteo basin east of the Rio Grande, southeast of the Nacimiento uplift is similar lithologically to the San Jose formation and may have been related genetically to the San Jose, although deposited in an entirely different basin. Stearns (1943, p. $310-311$ ) found Duchesnean (late Eocene) fossile in the upper part of the Galisteo which is as much as 4,500 feet thick. 
The lower part may be early and middle Eocene in age, and may contain Paleocene beds.

Igneous Rocks

Three dikes of igneous rock occur along joints in the Tapicitos member of the San Jose formation on the Tapicitos Plateau. The southernmost dike is in secs. 24 and $25, T, 26$ N., R. 3 W. It is about $11 / 4$ miles long and trends about N. $8^{\circ} \mathrm{E}$. North of this, in sec. 24, is another dike about three-fourths of a mile long, trending N. $27^{\circ} \mathrm{E}$. North and east of the short dike is another dike beginning in the southern part of sec. $18, T .26$ N., R. 2 W. and extending northward past the northern boundary of the area. This dike trends $\mathrm{N} .8^{\circ} \mathrm{E}$, and is about 6 miles long including the part north of the area mapped. None of the dikes appears to be more than 50 feet wide, and all are nearly vertical. The dike rock is harder than the enclosing sedimentary rocks, and the dikes form narrow ribs rising above hills eroded in the sandstone and shale of the Tapicitos member.

The petrography of the dike rocks was not studied. The rock consists of phenocrysts of plagioclase and pyroxene in a dense matrix, and at places contains stoped, partly digested material much of which is recognizable as altered wall rock of the San Jose formation. The wall rock is baked for several feet on either side of the dikes.

The dikes at places have vertical and horizontal joint 6 . In the vicinity of Tapicitos Creek, some of the horizontal foint can be 
traced into bedding planes in the adjacent sandstone and shale of the Tapicitos member, and the horizontal joints appear to be related in some manner to the bedding of the sedimentary rocks into which the magma of the dike rock was intruded.

The dikes described above are similar in petrography, structure, and alinement to those of a broad dike swarm a few miles to the north. The north-northeast-trending lamprophyre dikes of the swarm were mapped by Dane (1948) who discussed their relations to the rocks of the northeastern part of the San Juan Basin, and concluded that they are probably of Miocene age. By analogy, the dikes in the present area are classified as Miocene(?).

\section{Tertiary or Quaternary Deponit.}

High Terrace Gravel

Gravel composed mainly of boulders, cobbles, and pebbles of granite caps small westward-sloping, high-level terraces at the foot of San Pedro Mountain. The granite of the pebbles, cobbles, and boulders is a pink to reddish-brown and purplish-brown, coarse-grained, dense, hard rock, identical with the Precambrian granite of the core of San Pedro Mountain from which it must have been derived. The deposits (QTg) consist of local remnants of gravel 50-100 feet thick preserved at altitudes ranging from about 8,000 feet to about 8,400 feet.

The gravel was deposited on an exosional surface at the foot 
of San Pedro Mountain probably at a time before the region had been dissected greatly by erosion. Remnants of the surface are found also at the northern end of the mountain where they are overlain at places by gravel composed mainly of fragments of sedimentary rocks. The remnants of the surface at the northern end of San Pedro Mountain (east of the area mapped) were correlated by Bryan and McCann (1936, p. 156) with the Ortiz surface which is said to be of Pilocene or Pleistocene age. A study of topographic maps of the northern part of the San Juan Basin indicates to the present writer that the erosional surface on which the high-level gravel was deposited at the foot of San Pedro Mountain may be equivalent to the surface on which the Bridgetimber gravel was deposited southwest of Durango, Colorado. The top of Bridge Tímber Mountain is at an altitude of about 8,270 feet. Atwood and Mather (1932, p. 89 ) considered the surface beneath the Bridgetimber gravel to be part of the San Juan peneplane of late Pliocene age, and the Bridgetimber gravel to be pre-glacial and thus of Pliocene or early Pleistocene age. For these reasons the high-level gravel along the western side of San Pedro Mountain is assigned a Pliocene or Pleistocene age. The gravel is believed to have been deposited as parts of alluvial fans lying on a westward-sloping pediment cut at the base of San Pedro Mountain. 


\section{Quaternary Deposits}

Terrace Gravel, Colluvium, and Stream-channel Gravel

Terrace gravel, colluvium, and stream-channel gravel ( $\mathrm{Qcg}$ ) occur in the San Pedro Foothills at lower topographic levels than the Tertiary or Quaternary gravel. The terrace gravel consist mainly of pebbles, cobbles, and boulders of Precambrian granite, but some of the fragments are sandstone and limestone from the Paleozoic and Mesozoic rocks exposed along the western side of San Pedro Mountain. The colluvium consists of slope wash and gravel slumped from terraces and lying on gently sloping canyon walls and sides of valleys. Streamchannel gravel occurs in the upper parts of some streams. The gravel and colluvium contain clay and sand reworked from Mesozoic and Paleozoic rocks.

Patches of gravel consisting mainly of pebbles, cobbles, and boulders of Precambrian granite cap low-level terraces along San Jose Creek and the western side of the Rio Puerco, near Rito Leche east of Cuba, and in sec. 33, T. 20 N., R. 1 E. The erosional surfaces preserved beneath the gravels are said by Bryan and McCann (1936, p. 164) to have been parts of the Rito Leche pediment which was defined as a widespread erosional level graded to a stage of the Rio Puerco younger than the "La. Jara pediment" but older than the present stage of the Puerco. The present writer found boulders of Precambrian granite littering the slopes of a narrow, westward-trending hill of rocks of the Nacimianto 
formation in sec. 14, T. 20 N., R. 2 W. It is apparent that this hill was formerly capped by terrace gravel, and this may indicate that the upper part of the Rio Puerco formerly flowed to the west for an uriknown distance. The present southerly course of the Rio Puexco in the southern part of the area may be the result of stream capture during the destruction of the Rio Leche pediment by recent headward-cutting of the lower part of the Rio Puerco.

Small patches of colluvium, colluvial boulders, and pebble and cobble gravel occur on eastward-facing slopes cut mainly on the Lewis shale in T. 25 and 26 N., R. 1 E. The deposits lying on the slopes in T. 25 N., R. 1 E. are mainly sandy colluvium containing large sandstone boulders slumped from the Fruitland, Kirtland, and Ojo Alamo cliffs above. Small patches of gravel lying on the Nacimiento formation, Ojo Alamo sandstone, Fruitland, and Kirtland formations in sece, 4, 8, and 17, T. 25 N., R. 1 E. are composed of pebbles and cobbles of granite, quartzite, and sandstone washed from the sandstone cliffs of the San Jose formation at the west.

\section{Alluvium}

Alluvium consisting of sand, silt, and clay with minor amounts of gravel occurs in the valleys of all of the major perennial and intermittent streams in the area. The alluvium is of Pleistocene and Recent age and is the youngest deposit of the area. Most the deposits of 
alluvium are being eroded at present, and the stream chantels are entrenched in arroyos cut recently in the alluvium. The alluvium (Qal) shown on the geologic map (Fig. 2) was mapped conservatively to include only the thicker alluvial deposits of the major valleys and does not include soil on slopes and minor patches of alluvium. Sparse data indicate that at most places the alluvium is less than 100 feet and commonly less than 50 feet thick. 


\section{GEOLOGIC STRUCTURE}

\section{Regional Setting}

The area of this report is in the east-central part of the San Juan Basin, a large Laramide structural basin in northwestern New Mexico and southwestern Colorado (Fig, 9). The east-west width of the basin is about 135 miles, and its north-south length is about 180 miles. The tectonic elements of the basin were first defined by Kelley (1950, p. 103-104), who also defined the boundaries of the basin. In later works Kelley (1955; $1957 \mathrm{a}$ and b; also Kelley and Clinton, 1960), slightly modified the terminology and selected slightly different boundaries for several units. Traditionally, the term San Juan Basin has been used by most geologists to denote the large feature an defined in Kelley's earlier (1950, p. 101) work, and it is in this general sense that the term San Juan Basin is used in the present report. The terminology of the structural elements shown on Figure 9 is about the same 2. Kelley's 1955 (p. 23 and fig. 2) terminology with a few modifications by the present writer.

The Central basin is asymmetrical with the structurally deepest part being much nearer the northern edge than the southern edge of the sasin. The Central basin is bounded along part of the northeastern, the northwestern, and the western sides by monoclinal structures, and is enclosed on the north, west, and south by gently inward-dipping structural platforms and slopes. The east-central structural boundary to the 
north-trending Nacimiento fault. This fault separates the basin from the Nacimiento uplift of which Sierra Nacimiento and San Pedro Mountain are parts.

North of the Nacimiento uplift the boundary of the Central basin jogs to the east, and the northeastern boundary is an arcuate belt of faulted anticlines and synclines which have been uplifted above the Central basin along a curving monocline. The southern part of the belt of folds was designated by Kelly (1957b, fig. 1, and p.47) as the French Mesa and Gallina uplifts. The northern part of the belt of faulted folds was called the Archuleta anticlinorium by Wood, Kelley, and MacAlpin (1948).

East of the French Mesa-Gallina uplift and the Archuleta anticlinorium is a shallow structural basin. This has been called the Chama basin by Kelley (1955, p. 23) and by Budding, Pitrat, and Smith (1960, p. 78). The western limb of the Chama basin merges into the uplift and the anticlinorium, and the eastern limb merges into the faulted monocline along the western side of the Brazos uplift. Although the Chama basin has the configuration of a shallow syncline, it is structurally cansiderably higher than/the Sap Juan Basin.

\section{Description of Structure}

\section{Structure Contour Map}

The structure of most of the area is portrayed on Figure 4 by structure contoux lines. The base of the Ojo Alamo sandstone wa chosen 
as the contour datum because the Ojo Alamo is persistent throughout the area, and because its base is easily determined and correlated by means of electric logs of most wells drilled for oil and gas in the region. On a few $\log s$ there was some uncertainty about the exact position of the base of the Ojo Alamo, but in nearly all the se cases the stratigraphic interval in question is considerably less than $\mathbf{5 0}$ feet, and thus is less than half the contour interval. Because of the unconformity at the base of the Ojo Alamo the datum is probably about the same age throughout the area. The contours on the base of the Ojo Alamo do not depict the exact structure of rocks older than the Ojo Alamo because of the unconformity; however, the structure of the older rocks is not greatly different from that of the Ojo Alamo except near the eastern edge of the present area. Also, the structure of rocks of the San Jose formation is not exactly the same as that of the Ojo Alamo because of the unconformity at the base of the San Jose.

Folds

Most of the present area of investigation lies within the Central basin, and its geologic structure is simple. The structural axis of the eastern part of the basin trends southeastward diagonally across the northeastern part of the area from the northwest corner of T. 26 N.. R. 3 W. to the southeastern part of T. 24 N., R. 1 W. where the axds terminates in the sharply folded rocks at the eastern side of the basin (Figs. 2, 4). 
Most of the present area lies south of the axis of the San Juan Ba a and the rocks of this region dip gently northeastward on a broad struct cal slope. At most places the dip is one degree or less. In the not thera part of T. 20 N., R. $2-4$ W. and the southern part of T. 21 N., R. 5 W., near the outcrop of the Cuba Mesa member of the San Jose formation, the northeastward dip increases to as much as $5^{\circ}$ locally where a narrow northwest-trending belt of steeper dips interrupts the homoclinal structural slope. South of this anticlinal bend in the southwestern part of the area the dips are mostly $1^{\circ}-2^{\circ}$ to the northeast.

In the southeastern part of the area the structure contours bend northeastward through a series of broad, low, north-northwest-plunging anticlinal noses, and the regional dip of the rocks is to the northwest. The dip of the rocks is locally more than $10^{\circ}$ in this part of the area but becomes progressively less to the northwest toward the interior of the basin. The anticlinal noses are in part older than the San Jose formation, as shown by angular unconformity between the Nacimiento and San Jose formations on some of the folds. However, the San Jose formation is folded also, and most of the major anticlinal and synclinal structures involving rocks of the San Jose formation seem to be rejuvenated older folds. Some of the folds were formed after deposition of the Cuba Mesa raember and duxing or after deposition of the Regina member. In general, the anticlinal noses are asymm cal, having comparatively steep western limbs and gently dippi astern limbs. In places, their 
symmetry is nearly that of monoclines or structural terraces. The broad curving anticlinal nose (here called the Johnson anticline) at the west side of Mesa Portal has a steeper eastern limb locally and is an exception to the generalization. The anticlinal nose crossing Mesa Portal in the eastern part of T. 20 N., R. 2 W. is asmmetrical to the west. This nose seems to be a northern extension of the La Ventana anticline (Fig. 12 ). The plunging anticline trending north-northwest across T. 20 N, , R. 1 W. and the western part of T. 21 N., R. 1 W. is here called the San Pablo anticline. The anticlinal nose in the central part of T. $21 \mathrm{~N}$, R. 1 W. east and northeast of Cuba, is here called the Rito Leche anticlinal nose. South of Rito Leche, the southeastern part of this fold has been rotated into a westward-sloping anticlinal bend, and farther south, the fold is overturned. The bend in the outcrop belt of the Mesaverde group near Senorito probably reflects the overturned western limb of this older fold which was deformed during the main elevation of the Nacimiento uplift in San Jose time and later. The southeastern part of the San Pablo anticline also has been rotated to the west to form an anticlinal bend south of the present area(Wood and Northrop, 1946, structure section E-E'; also see cross section D, Fig. 13 of this report).

In a narrow belt along the eastern side of the area the rocks dip $2^{\circ}$ to $20^{\circ}$ west and the contours trend more or less north. However, the contours are locally deflected by north-northwest-plunging anticlinal noses in the subsurface. These noses are not reflected noticeably in the 
structure of rocks of the San Jose formation at the sunface in this region, presumably because they were formed before deposition of the San Jose as indicated by the unconformity at the base of the formation. The position of contours on the noses is based mainly on surface stratigraphic relations in the San Pedro Foothills indicating thickening and thinning of the Nacimiento formation beneath the unconformity. The depicted position of the buried anticlinal nose in the southern part of T. 24 N., R. 1 W. and northern part of T. 23 N., R. 1 W. is controlled by subsurface data also. The depicted position of the nose in the eastern part of T. 24 N., R. 1 W. also is controlled in part by subsurface data as well as by surface data which indicate a considerable thinning of the Nacimiento formation on this structure. The nose shown in the east-central part of T. 22 N., R. 1 W. is an interpretation based mainly on the observed thinning of the Nacimiento formation beneath the Cuba Mesa member of the San Jose formation in the southern part of the San Pedro Foothills. Along the eastern side of the area at the foot of Sierra Nacimiento and San Pedro Mountain the sedimentary rocks have been folded up abruptly, and at places are vertical or overturned and dip steeply eastward. Dips as low as $50^{\circ}$ east were observed in overturned beds at a few places in the southern part of the San Pedro Foothills, but at most places the dips are steeper than this. Generally, the greatest overturning occurs in the beds preserved on the highest parts of the ridges, and beds exposed in the bottoms of the deep canyons are nearly vertical or dip steeply west. 
The sharp folding occurs along a north-trending synclinal bend located at most places near the eastern edge of the outcrop belt of the Regina member of the San Jose formation (Fig. 2). The axis of the synclinal bend is parallel to the Nacimiento uplift and lies west of the Nacimiento fault.

North of San Pedro Mountain, the steeply dipping latest Cretaceous and Tertiary rocks of the Northern Hogback Belt are involved in a westfacing monoclinal flexure and are bent eastward around a low, northeasterly trending anticline which lies north of the Nacimiento uplift in the northwestern part of T. 23 N., R. 1 E. In the west-central part of T. 24 N., R. 1 W., the west-dipping rocks are bent into a sinuous but generally northward trend along a monoclinal flexure that forms the western side of the French Mesa-Gallina uplift which lies just east of the northeastern part of the present area. The dip of rocks on the western limb of the monoclinal flexure becomes progressively less northward from T. 24 N. , R. 1 E. In T. 26 N., R. 1 E. the westward-dipping rocks of the monocline trend north-northwest along the west flank of a northwest-plunging anticlinal nose. On the basis of the outcrop pattern of the Mesaverde group, the trace of the axial plane of this nose probably trends diagonally through sec. 2, T. 26 N., R. 1 E. The fold, here called the Puerto Chiquito anticlinal nose, is on the western flank of the north-trending French MesaGallina uplift which lies east of the present area (Fig. 12). 
The synclinal bend west of the Nacimiento fault extends northward and forms the foot of the monocline that lies north of the uplift. In the soutbeastern part of T. 24 N., R. 1 W. and adjacent parts of T. 24 N., R. 1 E. and T. 23 N., R. 1 W., a shallow northeast-trending syncline and the paralle1, narrow, sharply folded Schmitz anticline lie west of a northeast-trending segment of steeply dipping beds on the monocline north of the Nacimiento uplift. Beds of the Regina member of the San Jose formation are the folded rocks at the surface. The interpretation of the subsurface structure of the Ojo Alamo sandstone shown by structure contours on Figure 4 is based on construction of cross sections using the dips of rocks of the San Jose at the surface. However, it is possible that the Schmitz anticline is mainiy a shallow structure in the San Jose formation, and the fold may die out with depth. The anticline in the San Jose could have been caused by crowding and crumpling near the southeastwarddipping axial plane of the major synclinal bend at the foot of the monocline. Fitter (1958, fig. 3) has shown these structures as a horst and a graben rathe $x$ than an anticline and syncline. The writer traced beds across the features shown as faults by Fitter without finding evidence of faults in the surface rocke.

Faulte

At place in the southeastern and eastern parts of the mapped area (Figs 2,4 the rocks are broken by normal faults. In secs, 24 and $25, T$. 20 N., R. 3 W., the Ojo Alamo sandstone on the Johnson anticline is 
broken by a north-northeast-trending normal fault downthrown to the west. The vertical separation on this fault is probably 50 feet or less, and the fault seems to die out rapidly to the north. Two normal faults, downthrown to the west, displace the Mancos shale, Mesaverde group, and Lewis shale near the crest of the San Pablo anticline.

Several normal faults displace the overlapping beds of the Regina member of the San Jose formation and older rocks in sec. 20, T. 22 N., R. $1 \mathrm{~W}$. (Fig. 2). The rocks are downthrown to the northeast on all the faults. The vertical separation of the Regina ramber along each of these faults is probably less than 200 feet. It is not known how these faults are related to the Nacimiento fault which lies a short distance to the east. Possibly the normal faults were formed during pre-San Jose folding and rejuvenated during or after deposition of the Regina the mber. The overlapping Regina beds are at lower altitudes neax La Jara Creek than they are several miles to the south. This may indicate/ that the faults were formed or rejuvenated during downbuckling of the basin as the block east of the Nacimiento fault was elevated.

Farther north in the San Pedro Foothills, the Mesaverde and younger rocks dip west much less steeply north of San Jose Creek than they do south of it. The dips are steeper again farther to the north. The local area of gentlex dips is in the position believed to be the sharply tilted eastern part of a northwest-plunging pre-San Jose syncline flanked on the north by a tilted northwest-plunging pre-San Jose anticline. The rocks 
east of the Mesaverde group are broken by several normal faults.

Rocks in the Northern Hogback Belt are cut at several places by faults that strike nearly normal to the beds. Three faults of this type displace steeply dipping rocks of the undivided Fruitland and Kirtland formations and the Ojo Alamo sandstone in parts of secs 10,11, and 15, T. 23 N., R. 1 W. (Fig. 2). Similar faults displace steeply dipping rocks of the Mesaverde group along the sharp bend in the hogback in secs, 21 , 29 , and $32, T, 24$ N., R. 1 E. On all the se faults the normal horizontal separation is left-lateral and the block south of the fault is offset to the east relative to the block north of the fault. The rocks south of the fault in sec. $32, T, 24$ N., R. $1 \mathrm{E}$. dip much less steeply than do the rocks north of the fault, and the apparent offset is not in the direction which would be expected if these faults were small tears formed during westwardthrusting of the Nacimiento uplift. A northerly trending normal fault displaces the Mesaverde group and adjacent rocks along Archuleta Arroyo near the center of T. 26 N., R. 1 E. The fault is downthrown to the east and, parallel to the fault, the horizontal separation is left-lateral.

A small overthrust fault occurs in the NE $1 / 4 \mathrm{SW} 1 / 4 \mathrm{sec}$. 11 , T. 21 N., R. 1 W. where overturned beds of the Fruitland and Kirtland formations, Ojo Alamo sandstone, and Nacimiento formation are offset about 50 feet along an eastward-dipping low-angle fault overthrust toward the we st. $T /$ is fault dies out in a short distance into overturned folded Cled of the Nacimiento formation. A high-angle fault downthrown to the 
west in the central part of sec. $23, T, 21 \mathrm{~N} ., R_{*} 1 \mathrm{~W}$. throws the upper part of the Lewis shale against the undivided $F$ ruitland and Kirtland $f o-m a$ tions. Another high-angle fault, downthrown to the weat, throws the Lewris shale against the Nacimiento formation in the NW $1 / 4$ sec. $23, T, 22 \mathrm{~N}$., R. $1 \mathrm{~W}$.

The north-trending Nacimiento fault and associated smaller faults (Fig. 12) which define the boundary between the San Juan Basin and Nacimiento uplift (Kelley and Clinton, 1960, p. 50-51) are east of the Mesaverde group and. were not mapped by the present writer, although they were observed at places. Judging by the structure cross sections of Wood and Northrop (1946) the maximum vertical separation on the Nacimiento fault may be more than 6,000 feet. Renick (1931) and Wood and Northrop (1946) have indicated that the Nacimiento fault is an east-dipping fault along which the Precambrian rocks of the Nacimiento uplift were elevated and overthrust toward the west. According to Renick (1931, p. 73) the westward movement on the fault was one-half mile to one mile. The concept of overthrusting is open to other interpretation as will be discussed later. The vertical throw on the Nacimiento fault becomes less at the north end of San Pedro Mountain (Fig. 13) and the fault passes northward into the Gallina fault (Fig. 12). The Gallina fault is a northeast-trending fault which is nearly vertical and is downthrown to the west near the Nacimiento uplift. The fault cuts across the etructurally bigh part of the French MesaGallina uplift, and terminates noxth of the $P$ to Chiquito anticlinal nose. 
Joints

Joints were observed at many places but were not mapped or studied for the present report. Kelley and Clinton (1960, fig. 2 and p. 19-22) portray and describe the joint systems of the San Juan Basin, including the area of the present report. Within the present area, according to Kelley and Clinton, joint sets trending N. $10^{\circ} \mathrm{E}, \mathrm{N}$. $75^{\circ} \mathrm{W}$. , and N. $35^{\circ} \mathrm{E}$. to N. $60^{\circ} \mathrm{E}$. are prominent. Sets trending about $60^{\circ} \mathrm{W}$, are especially persistent near Lindrith, and sets of S. $65^{\circ} \mathrm{E}$., S. $65^{\circ}$ W. , and S. $25^{\circ}$ W. are prominent west of the northern end of the Nacimiento uplift.

From the point of view of topographic expression, joint sets trending from about N. $8^{\circ} \mathrm{E}$. to about N. $25^{\circ} \mathrm{E}$. are the most prominent and, in places, there is a marked "grain" to the country following the trend of these joints. This grain is particularly noticeable in the northcentral part of the area north of Canada Larga. Here many of the tributaries of the major westward-flowing canyons follow north-northeast (or south-southwest) courses, and the dikes of igneous rock on Tapicitos Creek follow the north-northeast trend. North-northeast-oriented faults, joints, and dikes are common features along the entire eastern side of the San Juan Basin from the Lucero uplift northward into Colorado. In the northern part of the basin, north of the present area, joints of the northnortheast set have been intruded by a great swarm of Miocene(?) lamprophyre dikes (Dane, 1948). 


\section{ANALYSIS OF REGIONAL STRUCTURE}

\section{General Statement}

The major geologic structures of the mapped area (Fig. 2) are folds of four general types which fall into two groups on the basis of orientation and symmetry. One group consist of folds whose axes are oriented in northwesterly directions. The other group consists of folds oriented mainly in a northerly direction.

The major northwesterly trending fold is, of course, the San Juan Basin. The northwesterly trending anticlinal noses in the eastern part of the area are regionally minor structures superimposed on the larger basinal feature and they do not obscure its general configuration (Figs. 4 , 12). The major west-facing synclinal bend west of the Nacimiento fault (Figs. 2, 12) parallels the north-trending Nacimiento uplift. North of the uplift the synclinal bend forms the foot of the sinuous, west-facing monocline at the southwestern edge of the French Mesa-Gallina.uplift. Near the northern edge of the area the structural relief on this monocline decreases and the synclinal bend at the foot of the monocline curves into a northwesterly trend nearly parallel to the axis of the San Juan Basin.

The northwesterly trending folds seem to indicate crustal shortening in a northeast-southwest direction that might imply a regional compressional stress oriented nearly in that direction. The northerly trending synclinal bend with its local areas of overturning along the western side of the Nacimiento uplift has been thought to indicate crustal 
shortening in an east-west direction caused by westward thrusting of the uplift along the Nacimiento fault (Renick, 1931, p. 71-79; Wood and Northrop, 1946). This would seem to imply a westerly oriented regional compressional stress. The unconformable relationship of the Nacimiento and San Jose formations in the present area indicates that the northwesterly trending folds began to be formed before the northerly trending folds. However, the unconformities within the San Jose indicate that the San Juan Basin continued to be depressed as the Nacimiento uplift was elevated. The final stages of depression of the basin and elevation of the uplift were attended by the main movement on the Nacimiento fault after the deposition of the San Jose, but before the deposition of the Tertiary or Quaternary terrace gravels. A major problem of analysis, then, is to determine how the two different structural trends (which might seem to require entirely different forces for their production) could have been developed contemporaneously or, at least, during overlapping time periods.

The San Juan Basin and its bounding uplifts exhibit the two major regional structural trends which characterize much of the eastern half of the Colorado Plateau. The Zuni uplift at the south side of the basin and the Archuleta anticlinorium and San Juan dome at the north side are northwesterly trending and are generally parallel to the northwesterly trending trough of the basin. The Defiance uplift at the west side of the basin and the Nacimiento and French Mesa-Gallina uplifts at the east side are 
northerly trending. Thus, the over-all symmetry of the basin that is partly included within these uplifts approaches the symmetry of a parallelogram or an oval whose long direction is oriented northwesterly, parallel to the orientation of the trough of the basin. Upon this over-all symmetry is superimposed the poorly-developed circular symmetry of the Central basin. This circular symmetry is largely the result of the curved northeasterly trend of the Hogback monocline and the curved northwesterly trend of the monocline that links the French Mesa-Gallina uplift and the Archuleta anticlinorium along the eastern side of the basin.

Kelley (1955, p. 66-67) suggested that the eastern part of the Colorado Plateau has been shortened in a northeasterly direction. The shorfening was said to be effected in the Zuni uplift, San Juan Basin and the Eastern Rockies as well as in other basins and uplifts farther west. Kelley suggested further that the crustal shortening would have necessitated right shift between the Plateau and the Nacimiento uplift, citing the staggered folds at the base of the Nacimiento uplift as suggesting right shift. The entire Plateau is said to have been under compression during Laramide deformation (idem, p. 74). Thus, if the crustal shortening is actual, the northwesterly trending folds in the present area might be interpreted to have formed under a regional compressional force oriented more or less southwest-northeast. The anticlinal noses land intervening synclines) would have beer horizontal drag folds formed by a horizontal component of movement along the Nacimiento fault. 
However, it is difficult to prove that the Zuni uplift, the San Juan Basin, and the adjacent uplifts to the north and east were formed under horizontal (tangential) compressional stresses, and that the geometry of these features necessitates crustal shortening. In a recent discussion of the origin of the Zuni uplift Kelley and Clinton (1960, p. 48) state that "there does not appear to be anything about the fracture pattern that could not have been formed by a predominantly vertical pressure", but "origin by a dominant lateral stress, on the other hand, is favored by overturned and thrust structures that are common bordering the Plateau." The same statements might be applied also to most other parts of the eastern sector of the plateau, and to such bounding uplifts as the San Juan dome. Geologic structures that clearly indicate (Laramide) origin by horizontal com pressional stress are not common in the eastern part of the Coloracio Plateau although they are present in some of the bounding uplifts. Furthermore, the northwesterly trending folds in the sedimentary rocks at the base of the Nacimiento uplift seem to be older than the fault or the uplift and they may or may not be related causally. The probable relationships of the folds and the fault are discussed in a later section of this chaptir.

On superficial examination, it might appear that the San Juan Basin and its bounding uplifts could have been formed as the result of differential vertical movements of large crustal blocks in a regional stress field that could have been compressional or tensional. Most of the present 
uplifts are ancient highlands or areas of thin pre-Cretaceous sedimentary cover, whereas a thick sequence of pre-Cretaceous rocks is present in the San Juan Basin. This might suggest an isootatic response to regional tensional stress. During the Cretaceous submergence of the Rocky Mountain geosyncline, the Paleozoic (and Mesozoic) Uncompahgre geanticline (of Read and Wood, 1947, fig. 2, p. 225) subsided less than the ancient Paradox-San Juan basins which lie south of the geanticline. The basins contained sequences of sedimentary rocks that we thick compared to the sedimentary rocks on the geanticlinal area. Differential subsidence during Cretaceous time is indicated by the fact that the Cretaceous rocks are not as thick at the northern edge of the San Juan Basin in Colorado as they are in the Central basin in New Mexico (Silver, 1951, fig. 4, p. 110). Dane (1960b, p. 67) indicates that the sources of some of the sediments of the Dakota sandstone were the Precambrian rocks in the area of the present Brazos uplift on the arcient Uncompahgre geanticline. Dane (1960a, figs. 2 and 3, p. 49,51$)$ shows also that there are unconformities within the Mancos shale at places on and near the Archuleta anticlinorium and also at the northwestern side of the San Juan Basin.

The major factor in upsetting whatever isostatic equilibrium may have existed before the Cretaceous subsidence would have been the influx of a tremendous amount of sediment derived from the region southwest of the present Colorado Plateau. The region of the present Chaco slope and Central basin received a thicker cover of Cretaceous 
sediments than did the ancient geanticline. The weight of these sedimerts, added to the weight of the thick section of olde $\mathrm{r}$ rocks it the ancient basin, would have created an isostatic differential between the b oad basinal area and the relatively narrow Zuni, Nacimiento, Archuleta, and Uncompahgre areas. Sediments eroded from the uplifts and deposited in adjacent basins late in Cretaceous time and in early Tertiary time would have tended to continue the isostatic adjustments.

The subsidence of the San Juan Basin seems to have required the transfe $r$ of a tremendous amount of subcrustal material from under the basin (regardless of what forces produced the basin), and some of this material probably migrated into the position of the San zuan dome which seems to be an upwarp complementary to the Central basin. During Laramide orogeny the ancient Uncompahgre geanticline exparded and encroached on the older sedimentary basins as it was transforme $d$ into the early Tertiary Uncompahgre-Sangre de Cristo geanticline. If vertical movements occurred in response to regional tensional stresis, the dopression of the San Juan Basin and the attendant isostatic rise of the horlering uplifts would have necessitated some regional crustal lengthening. Part of the solution to the problem of whether the San Juan Basin and associated uplifts were formed in response to regional compressional or tensional forces depends on determining whether the basin has been lengthened or shortened. The stratigraphy and geologic structure of the present area 
(Fig. 2) provide evidence concerning the nature of the Laramide deformation of the entire region.

\section{Nacimiento Fault}

For almost 50 miles north of the Puerco fault belt the eastern boundary of the San Juan Basin is the north-trending Nacimiento fault along which the basin is depressed relative to the Nacimiento uplift (Fig. 12). The northwesterly trending folds of the basin terminate abrupty against the fault which transects them, and the folds are tilted westward along the persistent major synclinal bend west of the fault. The synclinal bend, which seems to be related symmetrically to the fault, is superimposed across the northwesterly trending folds, and the stratigraphy of the San Jose formation provides evidence that the synclinal bend is younger than the northwesterly trending folds.

Renick (1931., p. 71-74) did the first detailed mapping of the Nacimiento fault which he called the "Sierra Nacimiento ove rthruat." According to Renick (p. 7.1) "most of the fault planes in this zone dip toward the eaat, showing that the mountain mase has been overthrust to the weat, toward the San Juan Basin. This overthrust is not a single fault, but in several places the movement has taken place along several planes of shear."

On most of his crose section Renick (pl, 1) shows the Nacimiento fault (or faulto) as relatively oteep and dipping east at about the same 
angle as the surface dips of overturned beds west of the fault. Renick (p. 72 and $\mathrm{pl}, 2$ ) describes the most complex structure as being at the north end of San Pedro Mountain (north of the San Pedro Mountain fault, Fig. 12) where there were said to be a series of overtarusts from cast to west with the fault planes dipping east at a relatively flat angle. Hovever, Hutson (1958, p. $37-38$ ) found only alte rnating limestone and clastic beds of the Madera limestone in this area, and concluded that Renick was mistaken in his interpretation of low-angle thrust faults. Hutson found that, at the northern end of the uplift, the Nacimiento fault is bigh angle, and dips about $83^{\circ}$ east.

Renick's map (pl. 1) shows the "Senorito sandstone lentil" of the Chinle shale resting on the Mancos shale in a manner suggesting a lowangle overthrust plate in the W. 1/2 sec. 13, T. 21 N., R. I W. However, Wood and Northrop (1946) indicate that this overlap is not present. The red beds shown by Wood and Northrop (1946) as Chinle shale thrown against Mancos shale in the E. $1 / 2 \mathrm{sec}, 11, T .21$ N., R. 1 W. are probably overlapping beds of the Regina member of the San Jose that axe poorly exposed beneath the Tertiary or Quaternary terrace gravel. Wood and Northrop (1946) have shown that Renick's (p1. 1, cross section F-F) interpretation of the supposed plate of Poleo sandstone thrust across the Chinle shale near the northwestern corner of T. 17 N., R. $1 \mathrm{E}$. is incorrect. 
Where the writer has seen the fault zone near the southern end of the Nacimiento uplift it appears to be high angle, either vertical or dipping very steeply east. Although the fault curves slightly at many places it is remarkably straight for its entire length of almost 50 miles. This suggests that the fault plane dips very steeply. However, because of generally poor exposures at most places, there is very little direct evidence to be observed concerning the attitude of the fault plane.

Overturned Beds

In examining the cross sections of Renick (1931, pl, 1) and Wood and Northrop (1946) it is apparent that the main evidence that would suggest thrusting from the east is the overturned, east dip of rocks at some places east and west of the fault zone. On the downthrown western side of the fault, the main area of overturned beds extends from the northeastern part of T. 22 N., R. 1 W. to the east-central part of T. 20 N., R. 1 W. (Renick, 1931; Wood and Northrop, 1946). The greatest overturning occurs in the east-central part of T. 21 N., R. 1 W.: the southeastern part of I. 22 N., R. I W.; and locally in the northeastern part of T. 20 N., R. $1 \mathrm{~W}$. At a few places the overturned beds dip east at angles as low as $40^{\circ}-50^{\circ}$, but at most places the dips are steeper. Where sedimentary rocks are preserved on the upthrown eastern side of the fault the beds are over-turned and dip east at a few places, but generally the beds dip west at angles ranging from nearly vertical to less than $45^{\circ}$. 
Near the northern end of the fault, the rocks west of the fault dip west at angles ranging from $70^{\circ}$ to nearly vertical, whereas east of the fault the rocks dip northeast at angles ranging from $20^{\circ}-50^{\circ}$. Along the southern third of the fault the beds are not overturned, the west dips are considerably less than $45^{\circ}$ at many places, and locally, rocks on either side of the fault dip toward each other. Near the southern end of the fault the rocks on both sides dip east.

In the present area (Fig. 2) the localities of sharpest overturning at the foot of San Pedro Mountain are places where stratigraphic evidence shows that the northwesterly plunging pre-San Jose anticlinal noses intersect the major north-trending synclinal bend west of the Nacimiento fault. The sharp overturning in the hogbacks near Senorito in the northeastern part of T. 21 N., R, 1 W. is in the vicinity of the intersection of the symclinal bend and the west-tilted southern part of the Rito Leche anticlinal nose. Steeply inclined beds occur adjacent to the Nacimiento fault farther south where the west-tilted southern part of the San Pablo anticline is crossed by the synclinal bend (Fig. 13), and similar relations are seen farthe $x$ south on other anticlines, although overturning does not occur near the southern part of the fault.

Several areas of gently-west-dipping beds west of the fault appear to be tilted pre-San Jose synclines. Immediately north of upper San Jose Creek in the southeastera part of T, 23 N., R. 1 W., the rocks east 
and west of the fault are not overturned, but dip west at angles ranging from nearly vertical at the Dakota outcrop to about $45^{\circ}$ at the Mesaverde outcrop, and about $64^{\circ}$ at the Ojo Alamo outcrop. The dips of the Nacimiento formation and Cuba Mesa member of the San Jose formation are steeper than dips of the beds to the east, and the Cuba Mesa member may be nearly vertical although the exposures are too poor to be certain. Here the Nacimiento formation is thicker than it is in areas to the north and south. To the south, as the dip of the Nacimiento formation becomes steeper (and the Mesaverde is overturned), the Cuba Mesa ramber of the San Jose formation rests on stratigraphically lower beds of the Nacimiento. Most of this thinning of the Nacimiento can be demonstrated to be stratigraphic.

The overturned beds present along parts of the Nacimiento fault could have reached their present structural attitudes as the result of west tilting on a monocline or on a drag fold (synclinal bend) along a highangle fault. The geometry of this concept is illustrated in Figure 13. Cross section A illustrates the northwestern parts of a pre-San Jose anticline and flanking syncline as they would appear in the subsurface near the eastern edge of the Central basin. Cross section B illustrates the structural condition farther south along upper San Jose Creek where the axial plane of the synclinal bend is west of the axis of the pre-San Jose symcline. Cross section C represents the structural conditions farthex to the south in sec. $11, T, 21 \mathrm{~N},, \mathrm{R}, 1 \mathrm{~W}$, where the axial plane of the synclinal bend lies west of the axis of the pre-San Jose anticline as shown 
by the southwestward thickening of the Nacimiento formation. Cross sect.on $D$ represents the structural conditions still farther south where the axial plane of the synclinal bend lies west of the tilted southern part of the San Pablo anticline.

The amount of folding during the main stage of formation of the major synclinal bend (during deposition of the Regina member of the San Jose) is shown by the attitude of the base of the San Jose formation (minus the west dip of the overlapping beds of the Regina member, cross section C). The southwestern limbs of the pre-San Jose anticlines are inclined more steeply than the base of the San Jose because the southwestern limbs of the anticlines were already inclined to the west (as much as $30^{\circ}$ at cross section C) before the folding of the San Jose began. Thus, where the axial plane of the synclinal bend lies west of the pre-San Jose anticlines, the western limbs of the anticlines reached overturned positions before the base of the San Jose had been folded into a vertical attitude on the eastern limb of the synclinal bend. Conversely, where the axial plane of the major eynclinal bend lies west of the axis of a pre-San Jose syncline, the base of the San Jose is inclined more steeply west than is the western limb of the syncline. The geometry of these concepts is shown diagrammatically on Figure 14.

From these considerations the writer concludes that the local areas of or irturned pre-San Jose rocks west of the Nacimiento fault do not, in the ns ves, lecessarily indicate westward thrusting on the fault. 
a. Pre-Son Jose anticline

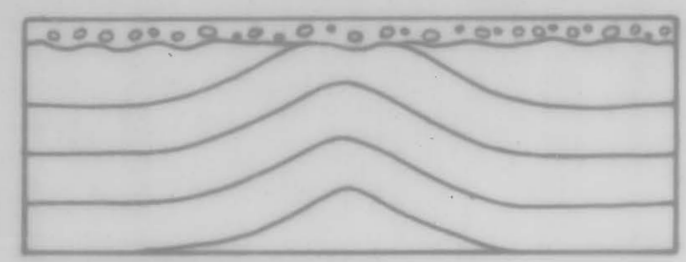

1
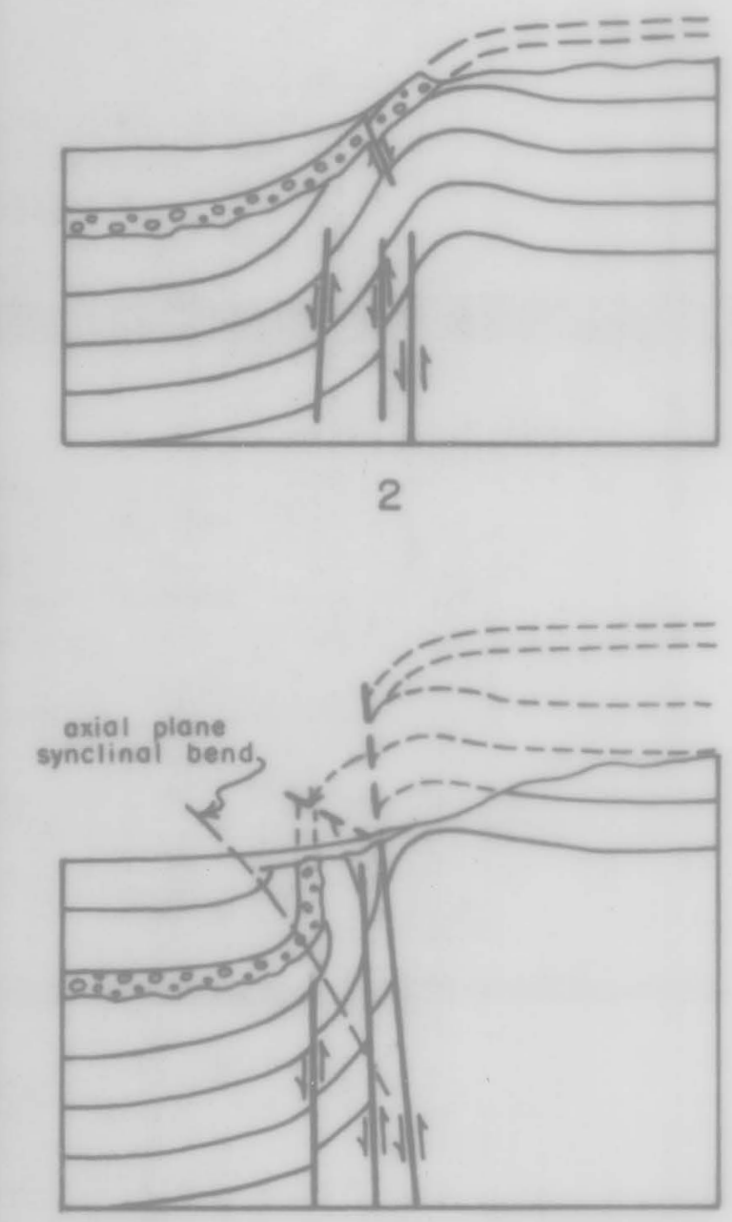

3

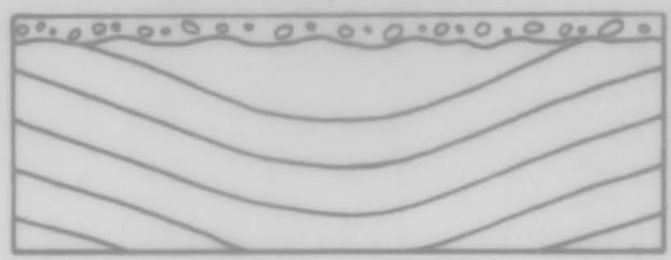

1

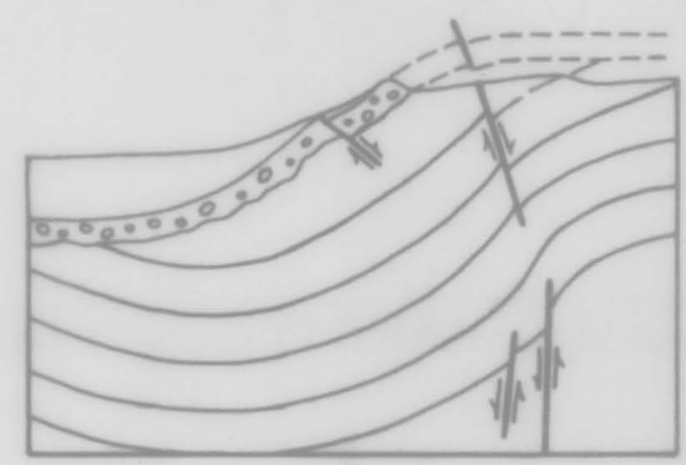

2

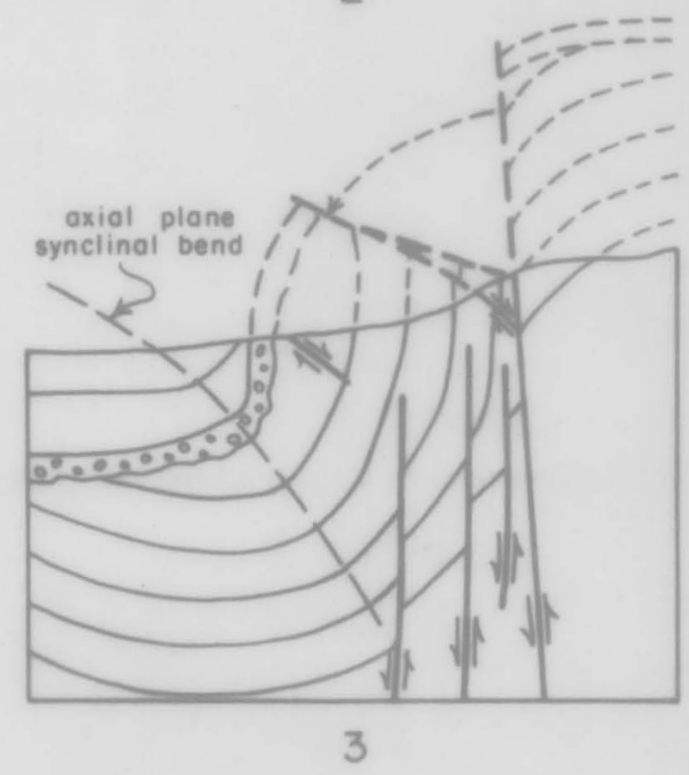

Figure 14:-- Diagrammatic cross sections showing possible stages of development of steeply dipping and overturned beds adjocent to a high-angle fault. 
Rather, at many places, the overtirned rocks are the t ted and steepened southwestern limbs of the northwesterly plunging pre San Jobe anticlines where the southeastern parts of these folds lie east of the axial plane of the major synclinal bend.

Synclinal Bend

The geometry of the synclinal bend, as reflected by the base of the San Jose formation, might be taken to indicate east-west crustal shortening accomplished along an east-dipping overthrust fault. As shown in Figure 15a, a point on an undeformed bed will be displaced through a horizontal distance $\left(x-x^{\prime}\right)$ as well as a vertical distance $\left(x^{\prime}-y\right)$ when the bed is folded concentrically. This kind of shortening would be accomplished also by parallel folding and thrusting (Fig. 15b).

On the other hand, as a result of vertical movement only, plastic deformation might be accomplished in such a manner that the limb of a fold is stretched and thinned, and a point, on the deformed bed is moved through only the vertical component $x-y$ (Fig. 15c). Apparent thinning resulting from vertical movement could be caused also by cleavage folding (shear cleavage) as shown diagraramatically in Figure $15 \mathrm{~d}$. Thus, the formation of a synclinal bend or a monocline might be attended either by horizontal shortening (Fig. $15 \mathrm{a}$ and b), or by vertical stretching and lengthening of the limb of the fold (Fig. $15 \mathrm{c}$ and d), or by both.

Figure 15 e illastrates the structural features observed in Heformed 


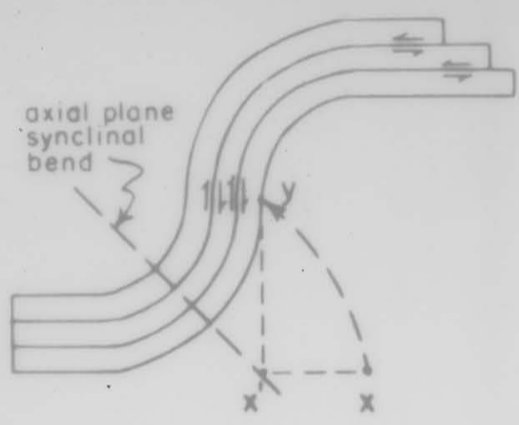

o. Concentric folding. Beds slip post eoch other and bedding planes locally ore concentric shears

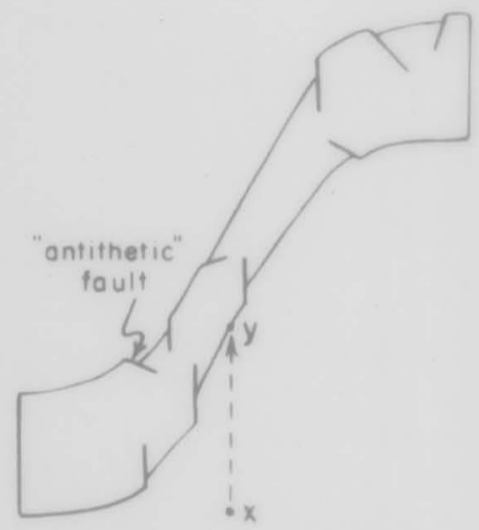

c. Similar folding with thinning of limb occomplished by plastic stretching and slight rupturing.

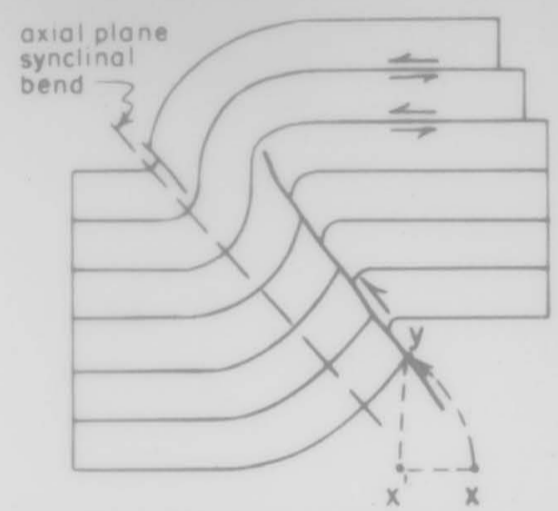

b. Porallel folding and overthrusting.

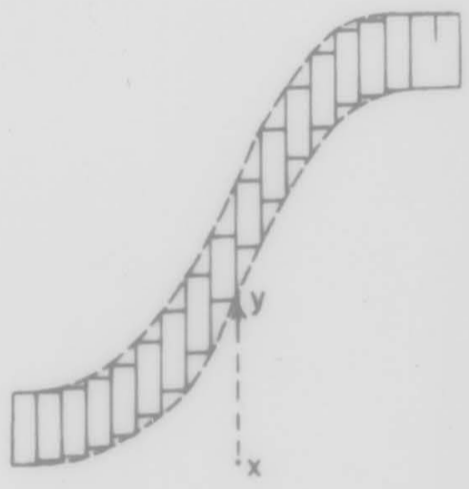

d. Similar folding with thinning of limb occomplished by cleavage folding (vertical shear cleavage).

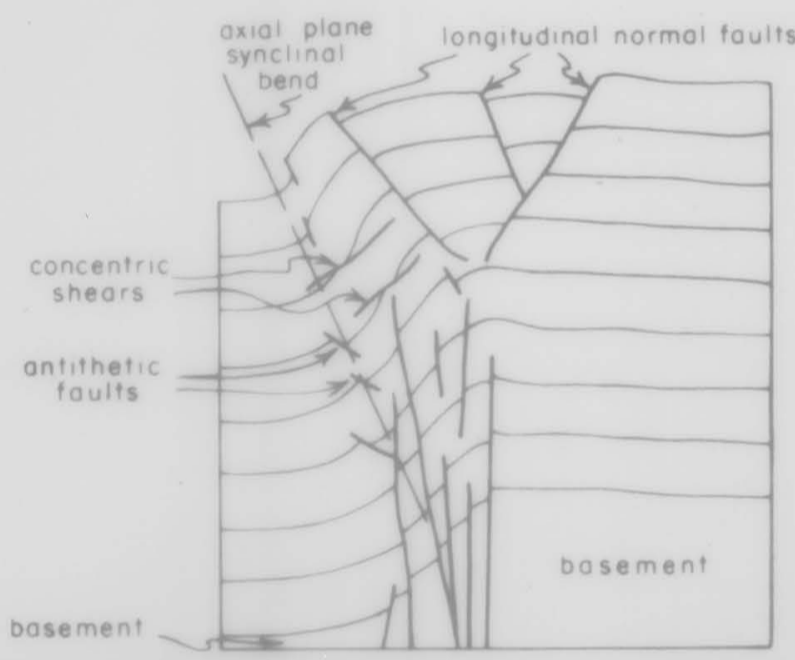

e. Folded and faulted beds draped across a shear fold in relatively rigid basement. Movement of bosement is predominantly vertical

Figure 15--Diagrammatic cross sections of several types of folds. 
models in which a plastic materia. ts on a relatively competent "basement" material which has folded slightly an then has ruptured in response to vertical uplift of the basement on one side of the model. Lengthening of the monoclinal limb is accomplished in the deeper part of the fold by movements along steeply inclined shears, whereas in the upper part of the fold, lengthening is accomplished by a combination of plastic stretching, concentric shearing, antithetic faulting, and grabening along longitudinal normal faults. Steeply inclined beds develop in the upper part of the fold because of crowding near the axial plane of the synclinal bend. This crowding is the result of a crimping effect brought:about bexanse the relative depression of the left side of the model is accomplished by steps along several planes of shear in the deeper part of the fold.

This concept of cleavage folding was used in constructing the diagrams in Figure 14 but was not used in constructing the cross sections in Figure 13 because the writer has no direct evidence of possible highangle faults in rocks older than the Lewis shale, except the faults that are subsidiary to the Nacimiento fault. However, the high-angle fault along which the steeply dipping beds of the Lewis shale are thrown against the less-steeply-inclined Fruitland and Kirtland formations in sec. 23, T. 23. N., R. I W. is similar to the high-angle faults illustrated in stage 3 of Figure $14 \mathrm{a}$ and $\mathrm{b}$. Another fault of this type throws the Lewis shale against the Nacimiento formation in the NW $1 / 4 \mathrm{sec}, 23, T .22 \mathrm{~N},, \mathrm{R}, 1 \mathrm{~W}$. 
Dane (1936, p. 95, 100-101, 109, 132) suggests that local thinning of units of the Mesaverde group in T. 19 N., R. 1 W. near Senorito is the result of strike faulting. He points out that the Mancos shale is not thinned but suggests that the position of the Mesaverde may have been favorable for steep thrusts, although the se faults were not observed. The antithetic faults downthrown to the east in sec. $23, T, 22$ N., R. 1 W. could have been formed in response to local tensional forces set up by slight stretch-. ing of the east limb of the synclinal bend.

Stretching of the steep limb of the synclinal bend as the result of plastic deformation or shear cleavage (or both) would be favored by the presence of thick units of shale such as the Chinle, Mancos, and Lewis, and the shale of the Nacimiento formation. The thinning of any particular unit of shale need not have been excessive inasmuch as the tensile strength of shale is low, and the stretching could have been distributed through small normal faults and innumerable small shears in all of the units. Furthermore, the stratigraphically higher units might not have been stretched and thinned appreciably because erosion undoubtledly attended the folding. The erosion of the upper part of the fold would obviate the geometric necessity of stretching (or faulting and rotation) shown by the dashod arrows in the reconstructed parts of the folds in stage 3, Figure $14 \mathrm{a}$ and $\mathrm{b}$, and the grabening shown in Figure 15e. Also, during the forma tion of the synclinal bend, the eastern part of the basin probably was shortened sightly in a northeasterly direction because the basin was 
crowded toward the uplift, and this crowding effect probably reduced the tensional stresses in the synclinal bend. Evidence of crowding is afforded by the fact that some of the northwesterly trending pre-San Jose folds were rejuvenated slightly during and after the deposition of the San Jose formation.

The synclinal bend extends north of the Nacimiento fault where the axial plane of the bend marks the foot of the large monocline. The synclinal bend probably marked the foot of a southern extension of the monocline along the western side of the Nacimiento uplift in early Eocene time. This conclusion is indicated by the fact that the gently tilted Regina. beds overlap sharply folded Paleocene and Cretaceous rocks in the southern part of the San Pedro Foothills (Fig. 13, cross section C). These overlapping beds consist largely of reworked Mesozoic sediments and do not contain large quantities of grantitic debris that would indicate that the core of the Nacimiento uplift was exposed to erosion in Regina time. Much of the present vertical separation on the Nacimiento fault seems to have developed after the synclinal bend (and the monocline to the north) was largely formed; i. e., after the deposition of the San Jose formation. Some further tilting of the synclinal bend accompanied the development of the Nacimiento fault.

From these hypothetical and factual considerations the writer concludes that the symmetry of the major symclinal bend does not indicate a geometric necessity for the Nacimiento fault to be an overthrust dipping 
east. Most of the structural features along the fault could have been produced by nearly vertical dieplacements along several shear planes, one of which became the main Nacimiento fault. The relative straightness of the Nacimiento fault and the dip of the fault plane observed at a few places indicate that the Nacimiento fault is likely to be a steeply dipping reverse fault as Hutson (1958) suggeated. The southern part of the fault may be nearly vertical.

Evidence of Strike-slip Movement

The staggered arrangernent of the northwesterly trending pre-San Jose antiiclines suggests that they were formed by crumpling resulting from right shift along the Nacimiento fault in an early stage of its development before there was much structural relief between the San Juan Basin and the Nacimiento uplift, and before the fault had ruptured the sedimentary rocks lying on the more rigid Precambrian basement. On the uplift the re are northwesterly trending features which might have developed as parts or counterparts of the folds in the basin. Some of the westward-dipping patches of sedimentary rocks on the western limb of the uplift (east of the Nacimiento fault) could be parts of synclinal troughs tilted during the formation of a monocline, and then faulted from the tilted synclines that now lie in the basin west of the fault. At any rate the re is no obvious correspondence of adjacent structures of the basin and uplift. This seems to indicate dislocation because of lateral shift during the major movement on the Nacimiento fault. 
Immediately north of the Nacimiento uplift there is "similar lack of correspondence of immediately adjacent structure eaf and west of the Gallina fault. However, the buried anticlinal nose west of the curving segment of monocline in the northern part of T. $23 \mathrm{~N} ., \mathrm{R}, 1 \mathrm{~W}$. and the southern part of T. 24 N., R. 1 W. might correspond to the highest part of the granitic core of San Pedro Mountain which has a northwesterly trend. Also, the sharp synclinal fold north of the Rito Leche anticlinal nose in the northeastern part of T. 21 N., R. 1 W: might correspond to the Bluebird Mesa sag on the Nacimiento uplift (Fig. 12). If these correspondences are more than coincidental a right shift of perhaps 3 miles is indicated along the northem part of the Nacimiento fault. Thus, the Nacimiento fault is probably a wrench.

In order to check the general validity of the mechanics discussed above, a simple model was constructed (Fig. 16). The model consisted of two flat pieces of cardboard laid together flush and partly covered with a viscous batter of flour and water. Dry flour was sifted on the batter to form a crust. The piece of cardboard representing the San Juan Basin was moved slightly so as to produce right shift, and a series of echelon folds began to develop in the batter across the joint between the pieces of cardboard. As the right shifting was continued, and the "basin" was depressed relative to the "uplift", a monocline formed in the batter above the joint between the pieces of cardboard. During this stage of deformation the parts of the echelon anticlines in the "basin" acjacent to the area of 
greatest relief on the monocline were overturned (Fig. 16, cross section A-A ). The anticlines adjacent to the area of least relief on the monocline were tilted west (Fig. 16, cross section B-B'). During continued right shift and depression of the "basin" the batter began to rupture and discontinuous high-angle faults formed along the monocline above the joint between the pieces of cardboard. As the faults began to form, the echelon folds ceased development. By a very slight under-thrusting of the "basin", the "uplift" was caused to bulge upward near the fault (Fig. 16, A-A').

Although there was no attempt to construct the model to scale with respect to strength of materials, etc., the experiment with the model indicates that the sequence of events postulated for the Nacimiento fault is mechanically possible with right shift along a high-angle reverse fault. The echelon folds in the "basin" part of the model are shallow-seated which suggests that the actual folds in the San Juan Basin may be shallow-seated also. Near the "uplift" the amplitudes of the folds are much greater, which accords with the postulation that the local patches of sedimentary rocks at the western edge of the Nacimiento uplift are tilted synclinal troughs faulted from the tilted synclines of the San Juan Basin.

The vertical displacement on the Nacimiento fault becomes greater from south to north. The greatest amount of vertical displacement on the Nacimiento fault is near its northern end where, south of the San Pedro Mountain fault (Fig. 12), the vertical separation may be as much as 6,500 feet. The axis of the San Juan Basin lies just a few miles north of the 


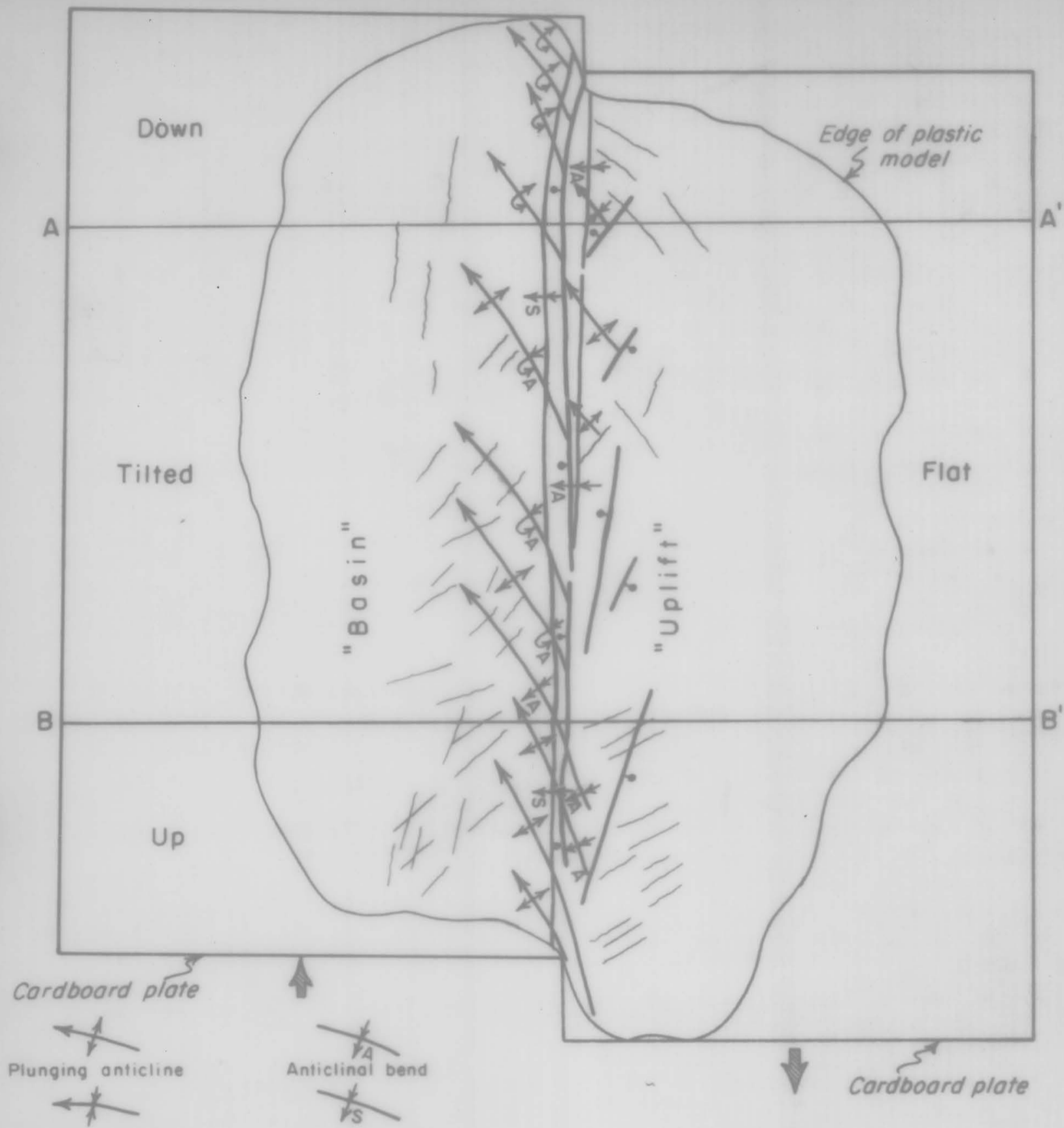

Plunging syncline

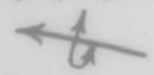

Anticline with overturned

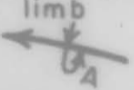

Recumbent anticline

Synclinol bend
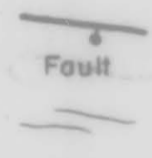

Tensional gosh

A

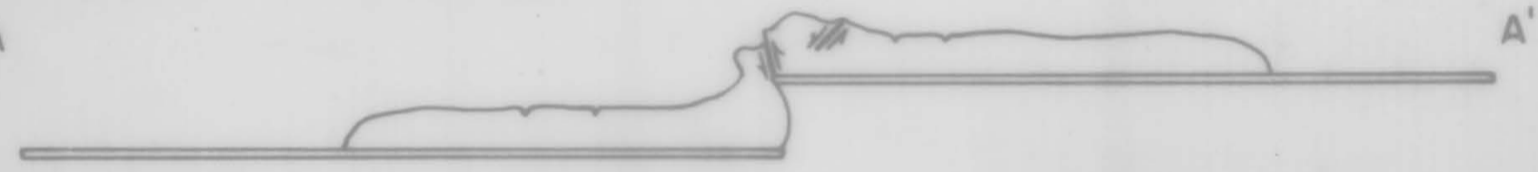

B

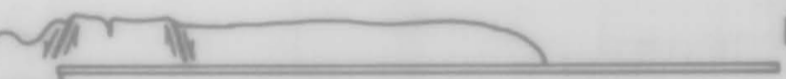

Figure 16.--Sketch and cross sections of a plostic model showing deformation resulting from right shift and tilting of o rigid plate beneath the model. 
northern end of the Nacimiento uplift, and the top of the Precambrian on the uplift is 11,000-16,000 feet higher than the top of the Precambrian in the adjacent part of the San Juan Basin. Figure 17a shows generalized structural profiles of the top of the Precambrian rocks on the Nacimiento and French Mesa-Gallina uplifts, and in the San Juan Basin west of the uplifts. It is apparent that, if both profiles were straightened or flattened, the profile of the basin would be longer than the profile of the uplifts. Because the vertical scale of Figure $17 \mathrm{a}$ is greatly exaggerated the difference in length of the straightened profiles would be exaggerated; nevertheless, even without the vertical exaggeration, the re is an appreciable difference in length.

At this point it is necessary to consider some large-scale geometric aspects of basin formation to determine whether the basement rocks of the San Juan Basin have been shortened or lengthened relative to the Nacimiento and French Mesa-Gallina uplifts. Although the curvature of the earth should be considered in constructing and interpreting geologic crass sections, it is not usually considered by most writers. In fact, the slight amount of curvature was not plotted in constructing the profile of Figure 17a. Recently the regional geometrical aspects of basin formation were discussed by Dallmus (1958) who pointed out that curvature should be taken into account because the earth has finite dimensions and mass, and there are limits to volume changes that are the result of the compression of rocks. In mathematical treatments the se finite dimensions should be 


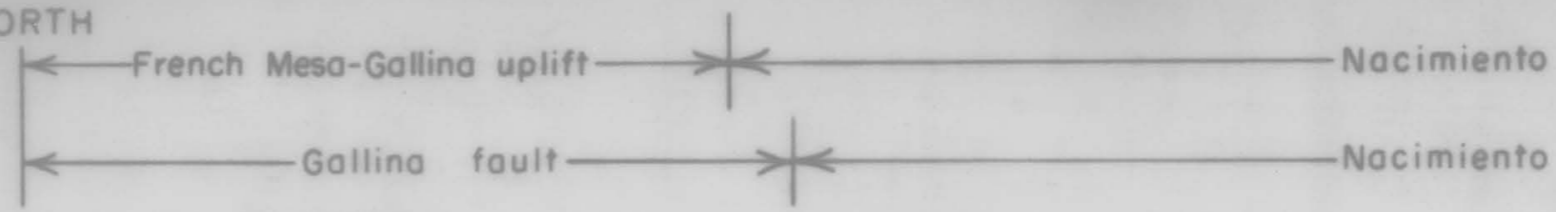

SOUTH

uplift

foult $\rightarrow$ ?

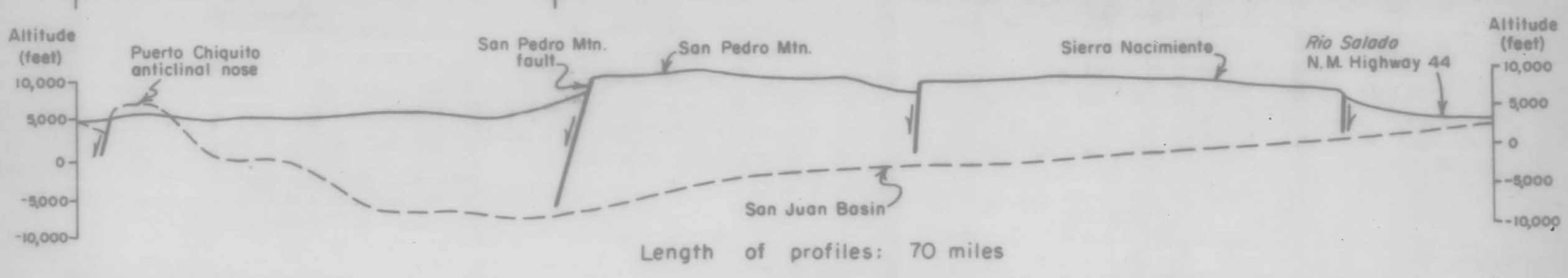

a. Structural profiles of top of Precombrion rocks of the French Meso-Gollino ond Nocimiento uplifts (solid line), and the eastern part of the Son Juan Basin (dashed line). Profiles are drawn through the areas of maximum structural relief east and west of the Gallino and Nocimiento foults.
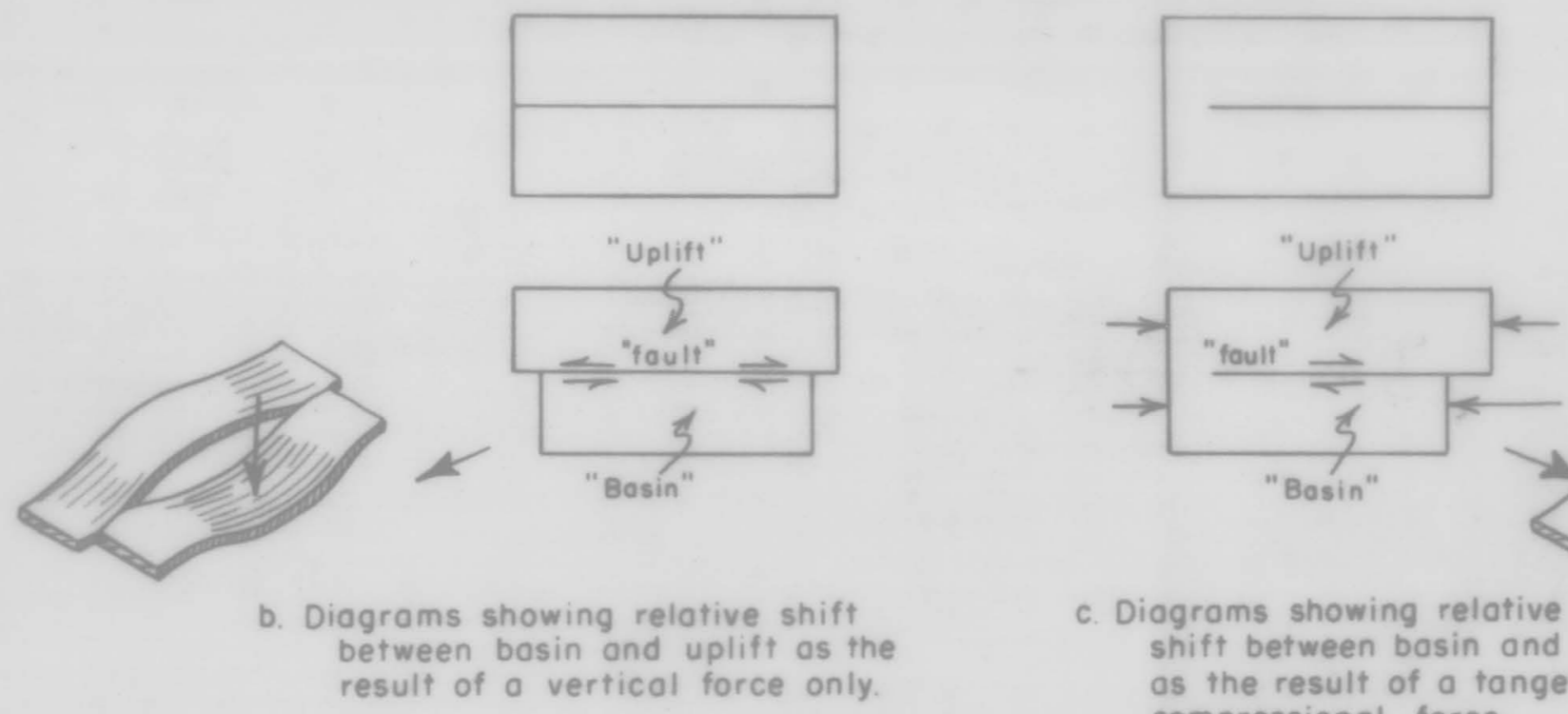

c. Diograms showing relative shift between basin and uplift as the result of a tangential compressional force.

Figure 17.--Structural profiles and diagrams showing possible directions of shift of the San Juan Basin relative to the French Meso-Gallino and Nocimiento uplifts. 
considered instead of the infinite planes, areas, and volumes that are implied by considering the surface of the earth as a sinuight line or plane in constructing conventional cross sections.

In the cross sections shown on Figure 18, arc $A C B$ represents the general curvature of the earth; line ADB represents a chord of the are $\mathrm{ACB}$; and line CO represents a segment of the radius of arc $\mathrm{ACB}$ whose center $\mathrm{r}$ is the center of the earth. Points A and B represent the edges of a segment of the earth's crust that has subsided.

In Figure 18a line AEB represents the general configuration of the upper surface of a structural basin that has subsided vertically through a distance CE. It is apparent that line AEB is shorter than line ACB; thus, if points $A$ and $B$ have not changed position relative to each other and to the center of the earth, the horizontal dimension of the basin has been decreased. Since there has been no change in the volume of the subsiding segment of the crust, the segmert has been compressed. The generated stresses are related directly to the length of the chord ADB and to the amount of subsidence CE.

Actually part of the compressional stress would be relieved by a slight lessening of volume as the result of bulk compaction of the rocks, and perhaps by a slight flowage from the edges of the basin. However, the volume change would be small, and most of the stress would be relieved by folding or thrust faulting which would, in effect, locally change the vertical shape or the vertical dimension (thickness) of the crustal 


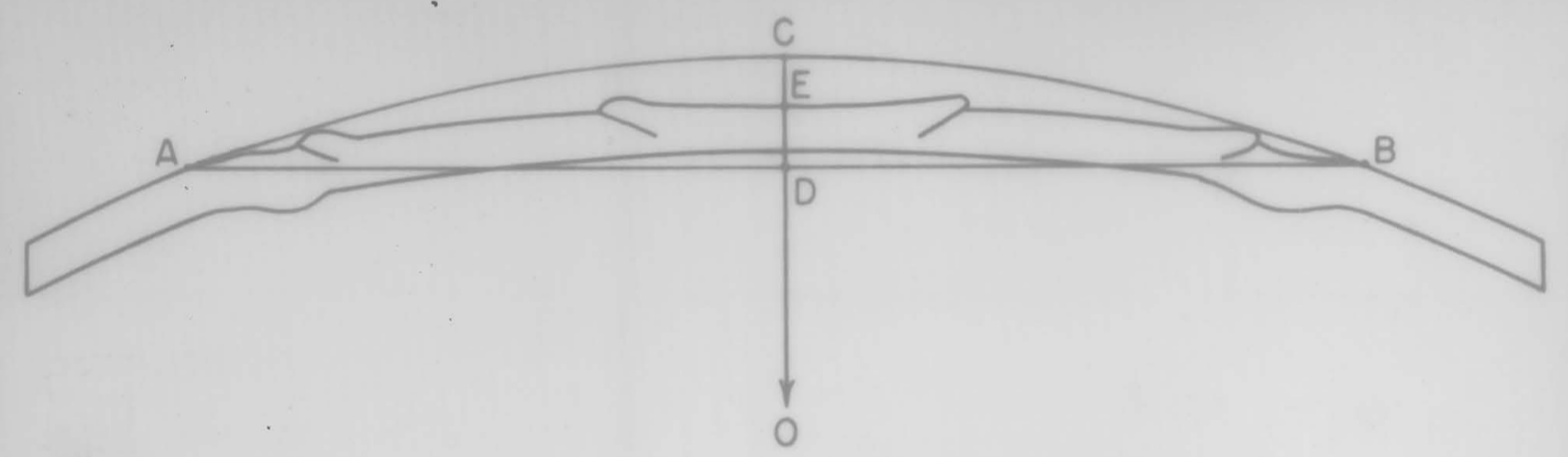

o. Early compressional phase of subsidence.

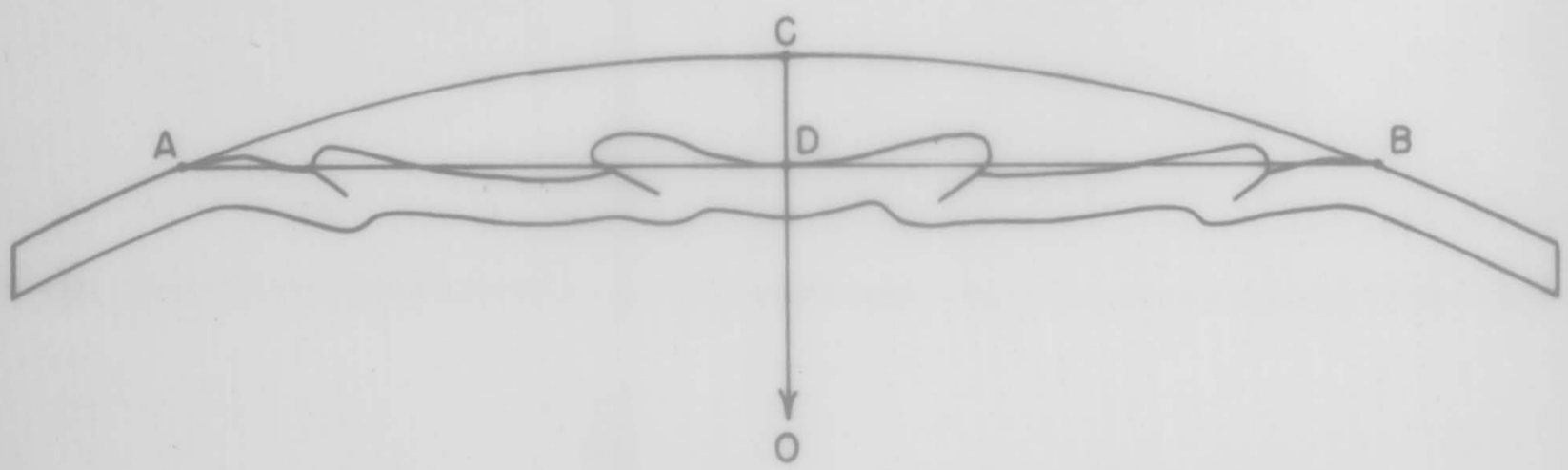

b. Maximum compressional phase of subsidence. Further subsidence will relax compressional stress and bring the basin into tension.

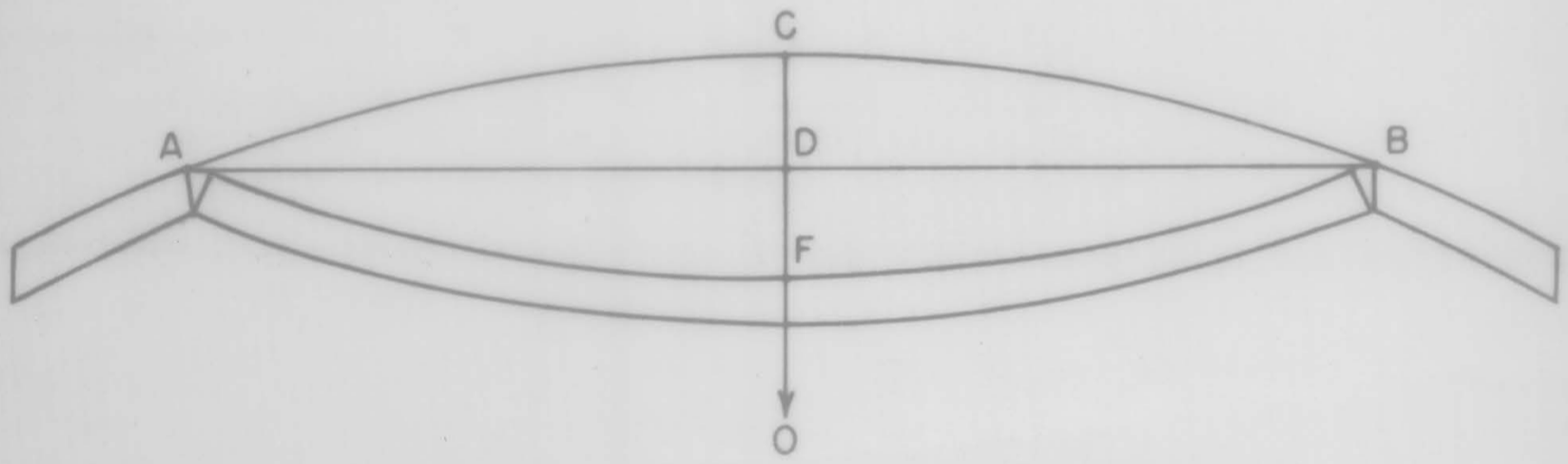

c. Maximum amount of subsidence necessary to bring basin into tension if preceding deformation had not been permonent.

Figure 18.--Diagrams showing compressional and tensional phases of subsidence of a segment of the earth's crust. 
segment. The folding and faulting might occur at the margins of the basin, or within the basin, or both. Probably the crust outside the basin at points $A$ and $B$ would be buckled or faulted also but, to keep the illustration simple, it is assumed that points $\mathrm{A}$ and $\mathrm{B}$ do not change position with respect to each other or to the center of the earth.

The maximum amount of shortening would occur when the basin has subsided through the distance $C D$ and the basin is the same length as the chord ADB (Fig. 18b). If all, or nearly all, the compressional stress is relieved by folding and faulting, further subsidence would relieve any residual compressional stress and bring the limbs of the basin into tension. However, if the deformation had been entirely elastic, which is unlikely, the limbs of the basin would not be stretched to generate a tensional stress in the crustal segment until the basin had subsided through a distance greater than CF (Fig. 18c). In Figure 18c the upper surface of the basin (AFB) is the same length as arC ACB, and CD equals DF. Thus, a basin which subsides because of a predominantly vertical force (caused by loading, at the top of the crust, or withdrawal of subcrustal material) will first be shortened and undergo compresision as a result of the shortening; then, if the basin continues to subside, the compressional stress will te released, and eventually the basin will be lengthened and undergo tension. However, if the basin subsides due to a vertical force in a regional tensional otress field it will not be compressed, but will be lengthered is it sul sides through distance CD. This, of course, would 
require that points $A$ and $B$ are displaced away from each other by the stretching force so that line ADB is the same length as line ACB. Further subsidence would lengthen the basin or cause the formation of a graben or half graben.

Dallmus (1958, Table 1, p. 888) has calculated the lengths of the chords (corresponding to line $\mathrm{ADB}$ ) and the median heights of arcs (corresponding to line $C D$ ) above the chords for great circle arcs ranging from $1^{\circ}$ to $5^{\circ}$. For an arc of $1^{\circ}$ the distance $C D$ is about 777 feet. The length of the profile of the Central basin of the San Juan Basin thown in Figure $17 \mathrm{a}$ is less than $1^{\circ}$ of the earth's circumference; however, the amount of subsidence of the basin relative to the ends of the profile is more than 6 times the greatest amount of subsidence (CF-approximately 1,500 feet) that would be necessary to bring the limbs of the basin into tention (Fig. 18c) and stretch them if the subsidence were caused by a predominantly vertical force (Fig. 17b).

Of course, the profile shown in Figure 17a portrays only the eastern pazt of the Central basin. Even so, the amount of Laramide suboidonce of the San Juan Basin as a whole seems to have been great oxough to longthen the entire basin if it had suboided in response to a predominantly vertical force. This would be so even if (in the extreme case represented by $\mathrm{Fi}$ gruge $18 \mathrm{c}$ ) the re had been no permanent deformation of the basin or It: mazgins during a compressional phase (Fig. $18 \mathrm{a}$ and b) of oubatdence. For example, consider a northeast-southwest profile across the masimum 
dimension of the basin from the vicinity of Gallup, New Mexico to Pagosa Springs, Colorado--an arc of a little more than $2^{\circ}$. South of Gallup the top of the Cretaceous Dakota sandstone is at an average altitude between 5, 000 and 6,000 feet. On the Archuleta anticlinorium southwest of Pagosa Springs the Dakota is at an average altitude between 6,000 and 7,000 feet. In the deepest part of the Central basin the top of the Dakota is more than 2, 000 feet below sea level. The structural relief of the basin is $7,000-$ 9,000 feet depending on where one considers the opposite edges of the basir to be. According to Dallmus (1958, Table 1, p. 888) the median height (CD) of a $2^{\circ}$ arc is about 3,185 feet. The $7,000-9,000$ feet of relief is more than the greatest amount of subsidence ( $D F=6,370$ feet) necessary to bring the southwestern and northeastern limbs of the basin into tension.

A northwest-southeast profile of the Dakota sandstcre between the French Mesa anticline and the Hogback monocline near the New MexicoColorado line extends about $1-1 / 2^{\circ}$. The average skructural relief of the profile is more than 6,000 feet, an amount of subsidence that is more than sufficient to bring the northwestern and southeastern limbs into tension. Thus, during the late stages of Laramide orogeny, the entire basin would have been lengthened if the subsidence was caused by a predominantly vertical force within the basin.

It can be seen from the se considerations that the geometry of the basinal fold shewn on rigure 17 a necessitates that the sout western limb of the Central basin is stretched (lengthened), or that it has mived toward 
the axis of the basin along a harizontal ccinponent. ise right shift along the Nacimiento fault indicates that the southweste $1 i_{1} \mathrm{ab}$ \& $\mathrm{s}$ no been atretched apprecially, but has moved toward tie axis of the ba in; thus the Central basin has been shortened relative to the Nacimiento and Irench Mesa-Gallina uplifts. However, this horizontal component of movement would be necessary whether the basinal trough subsided due to a vertical force, and "pulled" the southwestern limb toward it, or whether the southwestern limb was "shoved" toward the axis by horizontal compressional forces causing the basin to be downbuckled.

From the foregoing discussion it can be seen that right shift along the Nacimiento fault could have been caused by differential yielding of the basin and the Nacimiento uplift either to a vertical force as illustrated in Figure 17b, or to local vertical forces (downbuckling of the basin) produced by nearly horizontal regional compression as illustrated in Figure 17c. The direction of shift on the Gallina fault provides a clue about the forces.

\section{Gallina Fault}

Near the northern end of the Nacimiento uplift the Nacimiento fault passes into the northeast-trending Gallina fault (Fig. 12). The Gallina fault is downthrown to the west as is the Nacimiento fault, but the vertical separation on the Gallina fault is lese than 1,000 feet in contrast to a vertical separation of more than 6,000 feet on the 
Nacimiento fault near the northern e d of the uyift (crcos se, ins and B, Fig. 13). The work of Hutson (1958), and Lookingbill 1953) shows that the Gallina fault cuts obliquely across part of the monocline north of the Nacimiento uplift, persists north-northeastward on the French MesaGallina uplift for almost 25 miles from the Nacimiento fault, and dies out north of the Gallina anticline (Fig. 12).

The apparent throw on the Gallina fault is down to the west between the Nacimiento uplift and the northern end of the French Mesa anticline. Farther north the apparent throw is down to the east on the Gallina and Rio Gallina anticlines but the throw is down to the west near the termination of the fault. Along the Gallina anticline the fault is high-angle reverse, and the fault plane dips west (Lookingbill, 1953). These differences in apparent throw seem to be a result of strike-slip movement that caused juxtaposition of folds which were not formed together originally and allowed some folds to develop independently on either side of the fault. The folds west of the fault indicate that the San Juan basin has been shortened relative to the part of the French Mesa-Gallina uplift that is east of the fault. This indicates right shift on the fault, and part of the northeastward shift on the western side of the fault seems to have been "taken up" geometrically by the northwest-plunging Puerto Chiquito antíclinal nose (Fig. 17a) which is strongly asymmetrical, having a steep northeatst limb and a bordering faulted syncline at the northeast. The Gallina fault dies out north of this fold. The axes of the Rio Gallina and Gallina Mountain 
anticlines parallel the Gallina fault, and they may be seconda, ve:tat drag structures related to the fault but partly younger th the p erco Chiquito nose and the monocline to the west, The amount of right hift on the Gallina fault is less than that on the Nacimiento fault mainly because the Gallina fault is near the trough of the San Juan Basin where the greatest amount of vertical movement occurred. Also, the alinement of the Gallina fault is much nearer to the northeast-southwest direction of shortening of the San Juan Basin than is the alinement of the Nacimiento fault--a factor which tends to decrease the amount of shift necessary to accomplish shortening of the basin along the Gallina fault.

If the trough of the San Juan Basin had subsided (relative to the French Mesa-Gallina uplift) in response to a regional vertical force within the basin (Fig. 17b) the northeastern limb of the basin would have been stretched or "pulled" southwestward toward the trough during the late stages of basin formation, and the lateral shift on the Gallina fault would have been left instead of right. However, the right shift on the Gallina fault indicates that the basin was downbuckled as it shifted to the northeast and encroached on the Archuleta anticlinorium (Fig. 17c). The shift that accompanied the major movements on the Nacimiento and Gallina faults in post-San Jose time seems to have been the last major stage of deformation, and most of the shift occurred after the stage of deformation (Fig. 1 8b) during which compressional forces could be attributed to the shortening and crowding within the basin and along its margin if it had subsided in 
response to a dominantly vertical regional force. Therefore, the right shift on the Gallina fault seems to be good evidence that the force which produced the northwesterly trending axis of the San Juan Basin was a regional tangential compressional force.

\section{San Pedro Mountain Fault}

Along the north side of San Pedro Mountain, the northern part of the Nacimiento uplift is tilted steeply to the north and dropped along a northwesterly trending normal fault (Fig. 12) which was called the San Pedro Mountain fault by Hutson (1958, p. 33). According to Hutson the fault plane dips $63^{\circ}$ northeast in the SW $1 / 4 \mathrm{sec}, 1, T .22$ N., R. 1 W. At the northwest this fault intersects the Nacimiento fault near the upper part of San Jose Creek in sec. 1, T. 22 N., R. 1 W., and the fault extends with a curved trace for about 10 miles to the southeast where it dies out. The dropping and northward tilting of the block north of the San Pedro Mountain fault causes the vertical separation on the southern part of the Gallina fault to be much less than the vertical separation on the Nacimiento fault (cross sections A and B, Fig. 13).

Wood and Northrop (1946) indicated left shift along the (then unnamed) San Pedro Mountain fault on their geologic map and indicated that the fault terminates at the Nacimiento fault. Hutson (1958, p. 37 and fig. 5) indicated that the block south of the San Pedro Mountain fault has shifted west (right shift), and he indicated that the fault extends west of 
the Nacimiento fault into the belt of steeply dipping beds along the major synclinal bend west of the Nacimiento fault.

Hutson's (1958, fig. 5) map shows the San Pedro Mountain fault extending west along San Jose Creek into sec. 34, T. 23 N., R. 1 W. and indicates that the Mesaverde group and younger rocks south of San Jose Creek are offset to the west relative to the same rocks north of San Jose - Creek. However, Hutson seems to have mistaken the Cuba Mesa member of the San Jose formation for the Ojo Alamo sandstone in sec. 3, T. 22 N., R. 1 W. south of San Jose Creek, and he mistakenly mapped the Nacimiento formation, Ojo Alamo sandstone, and undivided Fruitland formation and Kirtland shale as the Lewis shale in this vicinity. There are no exposures in the broad gravel- and alluvium-filled valley of San Jose Creek to substantiate the offsets of the Mesaverde group and younger rocks depicted by Hutson. The outcrops of the Dakota sandstone and lower part of the Mancos shale in sec. $35, T, 23 \mathrm{~N},$, R. $1 \mathrm{~W}$, are offset to the east relative to outcrops in sec, 2, T. 22 N., R. 1 W., as shown by Wood and Northrop (1946). However, this offset seems to be mainly the result of right shift on an easterly trending fault in the southern part of sec, $35, T, 23$ N., R. 1 W. This fault seems to terminate at the Nacimiento fault, and if it is part of the San Pedro Mountain fault it has been displaced by right shift along the Nacimiento fault. The present writer concludes the re is no particular evidence that indicates the San Pedro Mountain fault does not terminate at the Nacimiento fault, and there is no evidence that indicates 
a major strike-slip component of movernent along the wit.

The San Pedro Mountain fault at the northern end of the Nacimien, uplift is near the area of maximum structural relief between the uplift and the San Juan Basin and might be a tensional fault formed in response mainly to dominantly vertical local forces. However, the $63^{\circ}$ northeast dip of the fault plane indicates that, as the block north of the fault moved down, the block also had a horizontal component of movement which accomplished some lengthening of the northern end of the uplift. This lengthening occured in a north-northeasterly direction almost parallel to the general trend of the Gallina fault (Fig. 12). If the San Juan Basin shifted northward along the Nacimiento fault and north-northeastward along the Gallina fault, as seems to be indicated, local horizontal tensional stresses, as well as vertical stresses, would have been set up in the vicinity of the junction of the faults, i.e., near the northern end of San Pedro Mountain. The geometry of this concept was not taken into account in the illustration of the general case (Fig. 17c), where the Nacimiento and Gallina faults are considered as segments of a straight line, but is shown on Figure 19. In the simplest case, if the basin were moved northward along the Nacimiento fault a gap would appear along the Gallina fault (Fig. 19b) as the basin is pulled away from the uplift and southern part of the French Mesa-Gallina uplift. A segment of the monocline near the axis of the San Juan Basin and west of the Gallina fault would then be unsupported along 


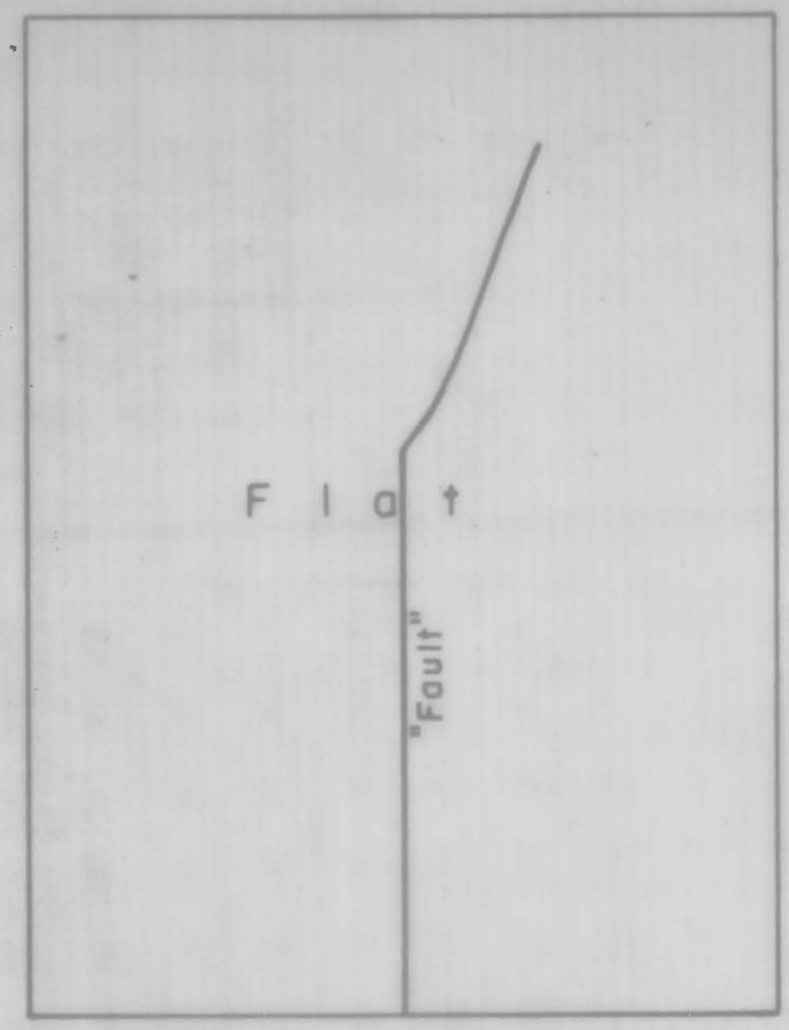

a.

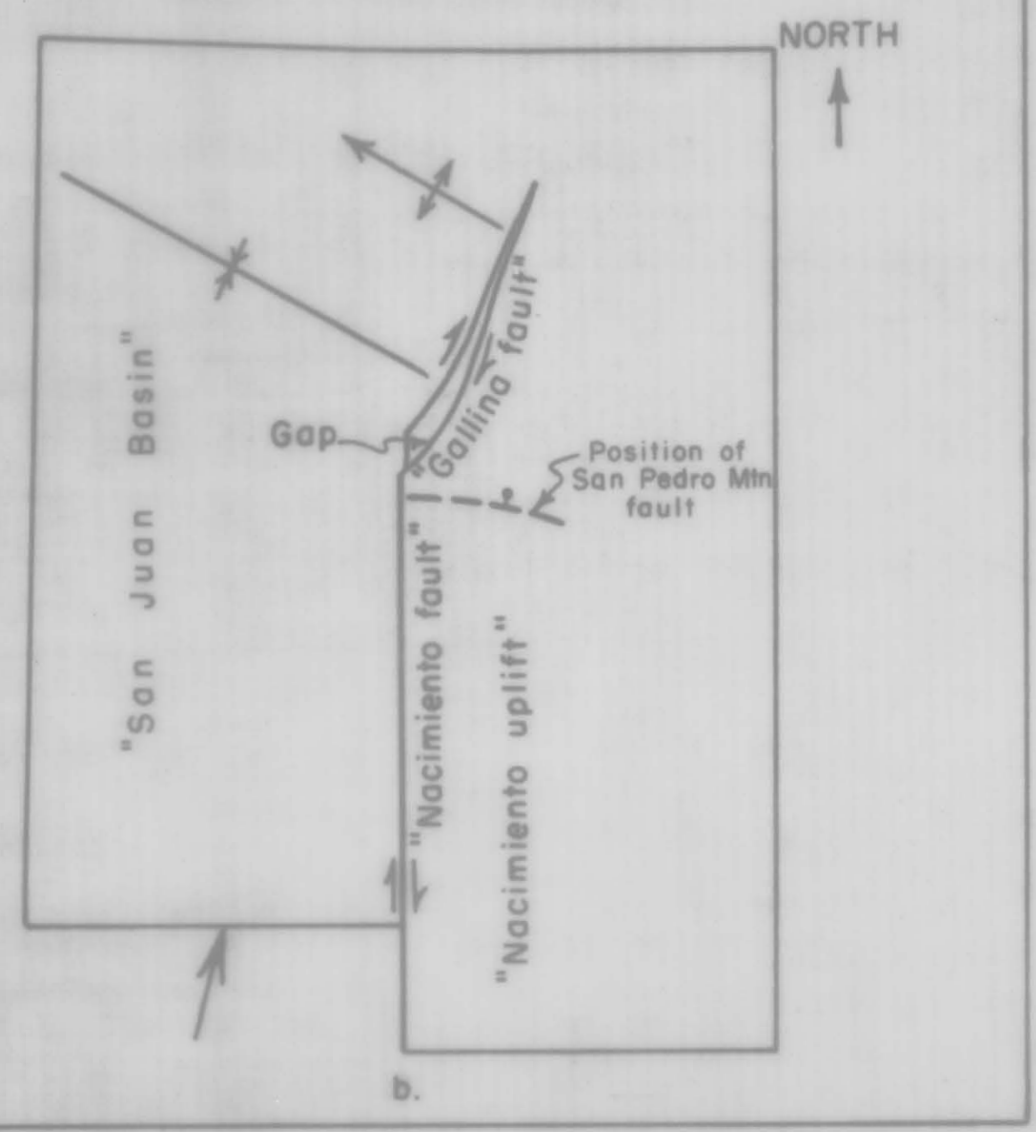

Figure 19.--Model showing area of horizontal tensional stress (gap) which develops during right shift on o foult having differently oriented segments. 
its eastern side, and the northern part of the Nacimiento uplift would be partly unsupported because of a gaping fissure at its northern end. Of course, there is no fissure along the southern part of the Gallina fault and there is no evidence that one ever existed. However, the slumping and north-northeastward lengthening of the northern part of the Nacimiento uplift that are implied by the geometry of the San Pedro Mountain fault would be consistent with the idea that local horizontal as well as vertical tensional stresses produced the San Pedro Mountain fault. Furthermore, the left shift on the transverse faults that cut the Mesaverde group in the SW 1/4 T. 24 N., R. 1 E. (Figs. 2 and 12) seems to indicate that the segment of monocline just west of Canon de Chavez slumped slightly and was tilted toward the southern part of the Gallina fault.

From these factors, it is likely that the San Pedro Mountain fault is a rotational normal fault hinged at the southeast end. The fault probably was produced by local vertical and horizontal tensional forces during downbuckling and north northeastward shift of the San Juan Basin along the Nacimiento and Gallina faults. The dropping and slight northeastward movement of the block north of the San Pedro Mountain fault slightly decreased the amount of right shift on the Gallina fault.

The angular unconformity between Pennsylvaxian and Pernian rocks on the block north of the San Pedro Mountain fault (Hutson, 1958, p. 11-12) might indicate that the fault is a rejuvenated ancient structural feature, or that it is superimposed on an ancient structure. The 


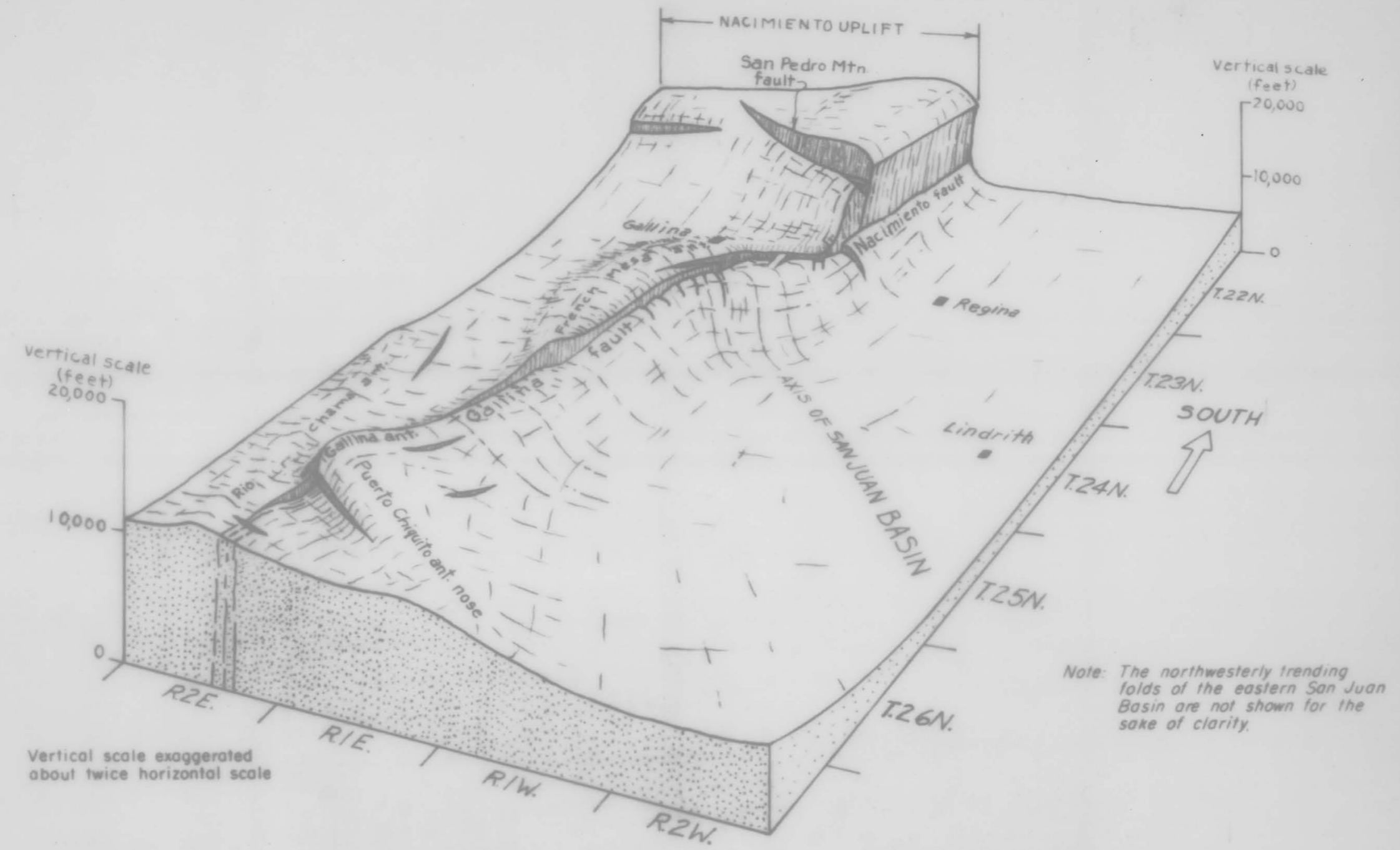

Figure 20.-- Model showing probable general configuration of Precambrion bosement rocks of the northern part of the Nocimiento uplift, the French Meso-Gallino uplift, and the adjocent part of the San Juan Basin. The upper surfoce of the Precombrian rocks is partly restored on the higher part of the Nacimiento uplift. 
relations of the San Pedro Mountain, Nacimiento, and Gallina faults are shown in three dimensions in Figure 20.

\section{Archuleta Anticlinorium}

The northwesterly trending Archuleta anticlinorium lies along the northeastern edge of the San Juan Basin north of the French Mesa-Gallina uplift. The anticlinorium is an interbasinal structural divide that separates the San Juan Basin from the Chama basin and the San Juan sag (Kelley, 1955, fig. 5, p. 23) which is a northwestern extension of the Chama basin in Colorado (Fig. 9). The anticlinorium is essentially a wrinkled and faulted arch, and this was emphasized by Kelley and Clinton (1960, p. 49-50) who referrod to the structure as the Archuleta arch. However, the present writer prefers the term Archuleta anticlinorium as originally used by Wood, Kelley, and MacAlpin (1948), and Kelley (1955) because it emphasizes the complex nature of the arch.

The axes of most of the folds of the anticlinorium trend northwesterly as do many of the faults. A few fold axes and a few faults trend northerly or northeasterly. The crest of the anticlinorium is marked by local structural highs ard sags most of which are slightly oblique to the general trend of the anticlinorium. The structurally highest part of the anticlinorium is on the Horse Lake and Willow Creek anticlines near the southeastern end of the anticlinorium. (See structure contouis: Dane, 1948; Wood, Kelley, and MacAlpin, 1948). The portion of the anticlinorium in New Mexico plunges southeast into the Chama basin (Fig. 21). 


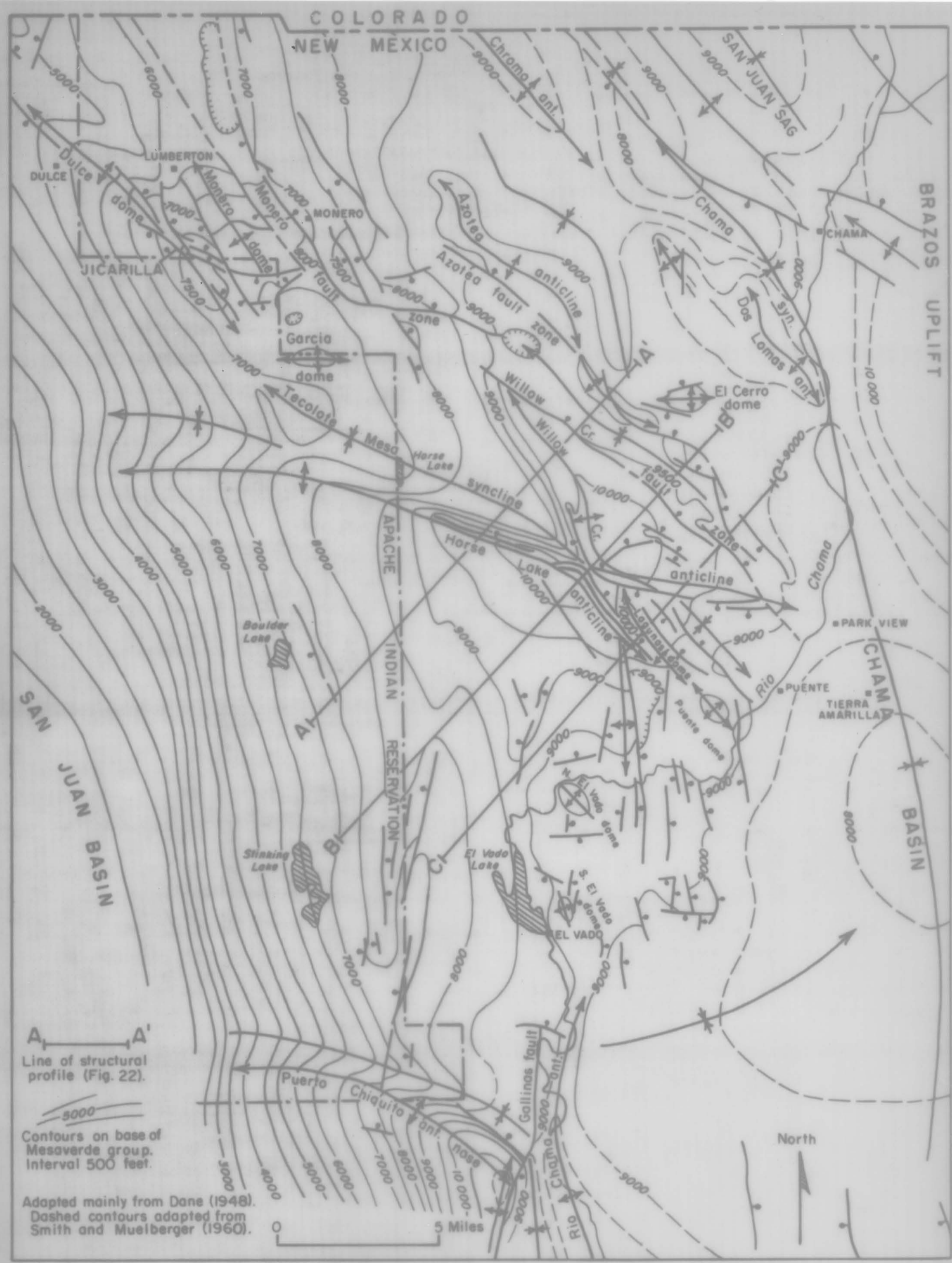

Figure 21.--Structure contour map of the southeastern part of the Archuleto anticlinorium and adjacent parts of the San Juan and Chama basins. 
The peculiar system of faulted folds in the Cretaceous rocks on

the Archuleta anticlinorium north of El Vado (Fig. 21) has been interpreted differently by Muehlberger (1960) and by Dane (1948). Muehlberger (1960, p. 109) interprets the Horse Lake and Willow Creek anticlines, and other structures on the anticlinorium, as having been formed by shallow seated "decollement folding." The Dakota sandstone and overlying rocks are said to have glided westward over older sedimentary rocks and to have been folded because of the driving force provided by the weight of the Cretaceous sedimentary rocks tilted up on the western flank of the Brazos uplift. There are several objections to this theory. Wells drilled to the basement of Precambrian rocks on the Horse Lake and Willow Creek anticlines and on South El Vado dome show that the basement is uplifted, and that rocks beneath the Dakota are folded or faulted up in apparent concordance with the structure of the Dakota. Thus, there appears to be no evidence of decollement. Certainly there is no evidence of shearing at the contact of the Dakota and the underlying Morrison formation where it is exposed in the canyon of the Rio Chama east of North El Vado dome. Furthermore, it is unlikely that a thick sequence of Cretaceous shale and sandstone ever stood on the western flank of the Brazos uplift to provide the driving force for a decollment sheet, because erosion must have attended the uplift of these rocks as shown by the fact that the Blanco Basin and El Rito formations bevel the Cretaceous and older rocks on the eastern edge of the Chama basin and the Brazos uplift (Smith and Muehlberger, 1960). 
According to Dane (1948) the folds were caused by horizontal compression, possibly with some vertically applied uplifting force. Dane explains the northwesterly trend of the Horse Lake anticline and the northerly trend of the Willow Creek anticline as having resulted from the 'we'dging together of two blocks, one of which had a northwesterly trend and the other a northerly trend. The wedging together is said to have produced the (Tecolote Mesa) syncline between the two blocks. Dane piostulated that the compressional stress was oriented northeast-southwest in the northern part of the anticlinorium, and east-west in the southern part of the anticlinorium.

The configurations of the Horse Lake and Willow Creek anticlines and the pattern of the fold axes and faults (Fig. 21) shed some light on the origin of these structures. The asymmetrical Horse Lake and Willow Creek anticlines are essentially faulted blocks tilted in opposite directions (Fig. 22). Between them lie two wedge-shaped slices that also are tilted in opposite directions. The southeastern wedge has been dropped slightly and folded to form Lagunas and Puente domes and adjacent faulted synclines (Fig. 21). The northwestern wedge is dropped to form the Tecolote Mesa syncline. The over-all configuration of the Horse Lake and Willow Creek anticlines and the intervening wedges is that of a faulted, northwesterly-elongated dome that has been tilted slightly toward the San Juan Basin. The southeastern and northwestern wedges are the dropped axial parts of the dome. 
The axes of the northwestern part of the Horse Lake atir Line and the southern part of the Willow Creek anticline trend generally N. $70^{\circ}$. $80^{\circ} \mathrm{W}$., whereas the axes of the northwestern part of the Willow Creek anticline and the southern part of the Horse Lake anticline trend $\mathrm{N}, 10^{\circ}-30^{\circ} \mathrm{W}$. The faults on the opposed steel limbs of the anticlines are generally parallel to the adjacent segments of the axes of each fold. The angle between the se two main "sets" of folds and faults is between $50^{\circ}$ and $60^{\circ}$, and this is suggestive of the angle between genetically related sets of shear fractures. In a general way, the large normal faults of the Willow Creek fault zone and the faults parallel to Lagunas and Puente domes trend in a northwesterly direction which bisects the angle between the trends of the major fold axes and their related faults. If the northwesterly trending faults are related genetically to the folds and faults trending $\mathrm{N} .70^{\circ}-80^{\circ} \mathrm{W}$. , and N. $10^{\circ}-30^{\circ} \mathrm{W}$, the northwesterly trending faults might have originated as longitudinal faults parallel to the axis of an elongate dome.

The over-all pattern of fold axes and faults is similax to the pattern of faults which might be expected to develop on an elongate dome or doublyplunging anticline because of longitudinal and transverse stretching of the upper part of the fold as it is uplifted (De Sitter, 1956, p. 201-211).

Longitudinal faults develop parallel to the axis because of stretching at right angles to the axis. Shear faults develop at acute angles to the axis because the fold is stretched parallel to the axis as well as at right angles, and the shears allow relief of the tensional forces in a component between 
the two main directions of tensional stress. In the terminology of De Sitter (1956, p. 208-211, fig. 147) the shear faults would be peri-anticlinal faults. The stretching of the shallow upper part of a fold causes lengthening which is accomplished often by grabening in the crestal part of the fold.

If the major northwesterly trending faults and the major faults that parallel the axes of the Horse Lake and Willow Creek anticlines ariginated because of tension in the uppe part of a dome, it is apparent that the vertical displaceme t on the faults would become less in the deeper part of the fold because the deeper part was not stretched as much as the upper part. Thus, the uparched basement rocks might have been displaced only slightly on each fault. Also, the vertical displacement on the faults becomes less in a horizontal direction away from the structurally high part of the dome, and the unfaulted Cretaceous rocks on the steep limbs of the northwestern parts of the Horse Lake and Willow Creek anticlines may overlie buried faults which are extensions of the faults that displace the Cretacoous rocks near the central part of the dome. Thus, the pattern made by the major faults and the curved axes of the Horse Lake and Willow Creek anticlines may have developed because of fracturing of the competent basement rocks during doming of the southeastern part of the Archuleta anticlinorium.

The evidence for this concept is circumstantial because it cannot be proved that the supposed shear and longitudinal faults were formed at the same time. Also, it cannot be shown definitely at present that the first 
stage of Laramide orogeny produced a broad low dome on the souty agrern part of the anticlinorium, although stratigraphic relations of latest Cretaceous and Tertiary rocks in San Juan Basin west of the anticlinortum seem to indicate this, as do unconformities within the Mancos shale on the anticlinorium. The Cretaceous rocks might have been deformed along very - $\theta$ ancient basement fractures of the Paleozoic uplift on which the anticlinorium is situated. The deformation would have proceeded selectively along those fractures that were oriented to relieve the Laramide stresses most easily. Nevertheless, the general pattern of the larger features is notably similar to a fracture pattern which might be predicted for a large elongated dome or doubly-plunging anticline.

If the southeastern part of the Archuleta anticlinorium originated as a broad dome the fracture pattern itself does not necessarily indicate whether the dome was formed by predominantly vertical forces (with no attendant crustal shortening), or by generally horizontal deep-seated compressional forces (with attendant bulging and crustal shortening). Also the pattern of deformation might have been caused by shift along a postulated deep-seated regional wrench zone (the Rattlesnake lineament) as suggested by Kelley and Clinton (1960, p. 95). However, it should be noted that, if the southeastern part of the anticlinorium has been shortened, the structurally high part on which Horse Lake and Willow Creek anticlines are aituated has been shortened more than the structurally lower part of the anticlinorium on which Dulce and Monero domes are situated. Thus, a 
local coupling action would have resulted between the Horse Lake-Willow Creek and Dulce-Monero structural culminations, and this may or may not be related to deep-seated regional wrench zones.

The configurations of the individual folds of the southeastern part of the anticlinorium indicate something about their origin. Locally, on the eastern flank of Horse Lake anticline and the western flank of Willow Creek anticline, the sedimentary rocks are vertical and at some places may be overturned slightly. The configuration of the Tecolote Mesa syncline and the adjacent steeply dipping limbs of the anticlines indicates shortening in a northeast-southwest direction, as does the confi-guration of the Lagunas-Puente domes wedge. The Horse Lake anticline has the same relationship to the Tecolote Mesa syncline that the Puerto Chiquito anticlinal nose has to the syncline on it northern flank, and the alinements of the Horse Lake and Puerto Chiquito folds are similar (Fig. 21), thus, possibly indicating a similar origin due to northeasterly oriented compression.

Thus it may be seen that, although the pattern of the major fault: on the Horse Lake and Willow Creek anticlines seem to indicate that the fault were formed by longitudinal and transverse tensional atresses in the upper part of a broad dome, the configuration of the individual folds indicates at least a small amount of shortening which would require a compressional force. These tres conditions are necesarily incompatible inamuch as they could have been produced during two (or more) 
phases of yielding of the competent basement rocks to a northeasterly oriented tangential compressional force.

A possible mechanism is illustrated by the structural profiles shown on Figuxe 23. In Figure 23a the hypothetical profile (at right angles to the axis of the southeastern part of the Archuleta anticlinorium) shows fault that might have developed on a low doubly-plunging dome which was upwarped between the San Juan and Chama basins because of a deep-seated nearly horizontal compressional stress. Tensional (longitudinal and shear) faults would develop in the higher part of the relatively competent basement rocks of the dome because of longitudinal and trans verse stretching, and these faults would be extended upward into the relatively incompetent sedimentary rocks which would be stretched more than the basement because they are higher in the fold. It seems likely that, once the faults were developed in the relatively competent basement rocks, further deformation would proceed along the se early-defined zones of structural weakness.

During the post-San Jose stage of deformation, when the major right shift occurred on the Nacimiento and Gallina faults, the San Juan Basin encroached northeastward on the Archuleta anticlinorium, and the San Juan Basin was depressed more than the Chama basin. The basement rocks of the Horse Lake block were tilted toward the San Juan Basin and this tilting probably deflected the compressional force locally so that it was directed slightly upward on the western flank of the dome (Fig. 23b). 

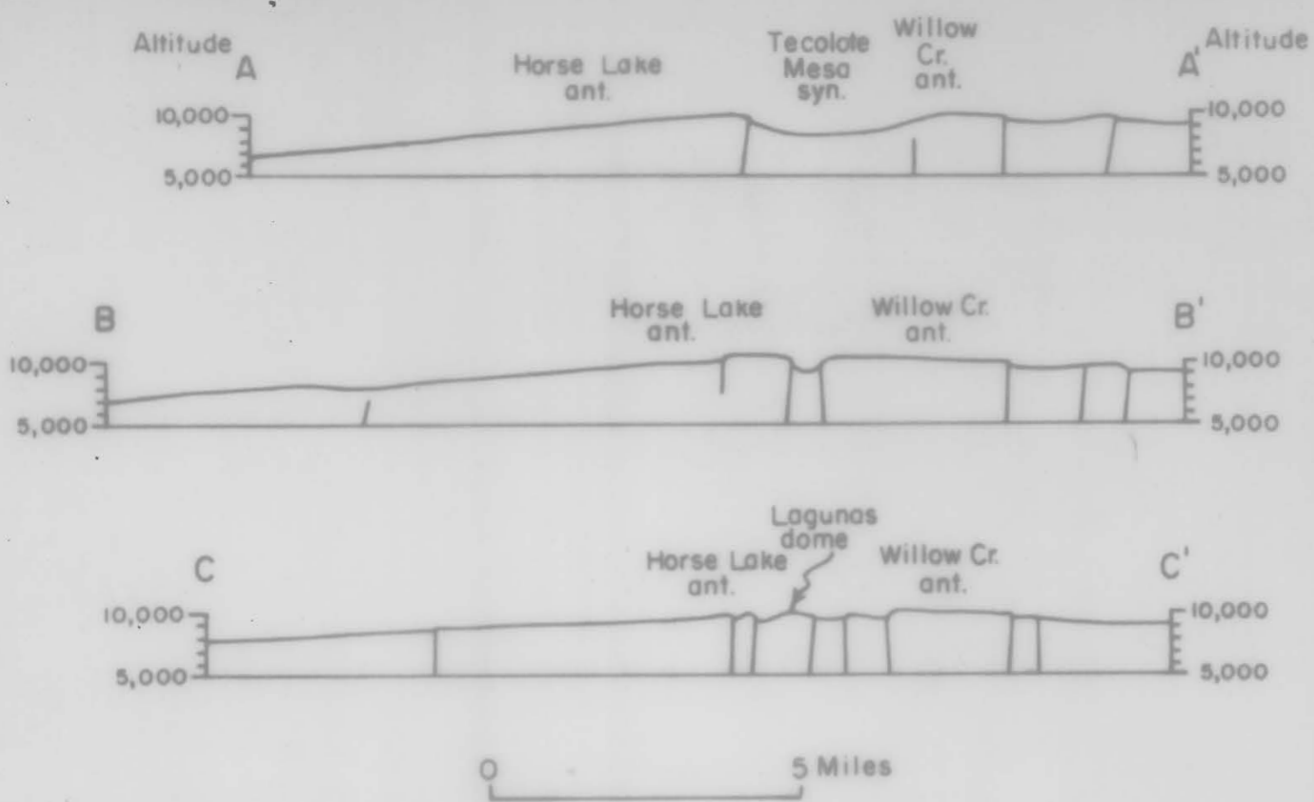

Figure 22.--Structural profiles of the Horse Lake and Willow Creek onticlines.

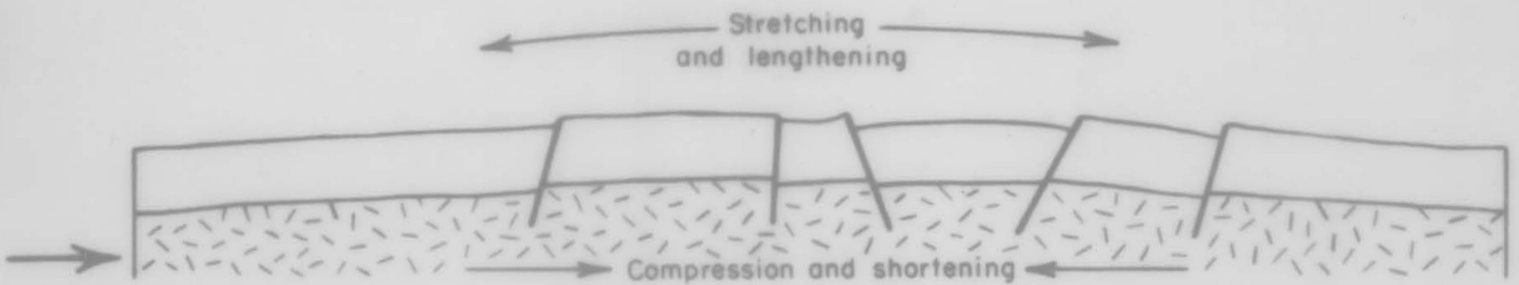

a. Normal foults resulting from stretching of the upper port of a dome formed by deep-seated compressional forces (arrows).

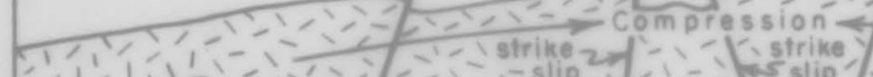

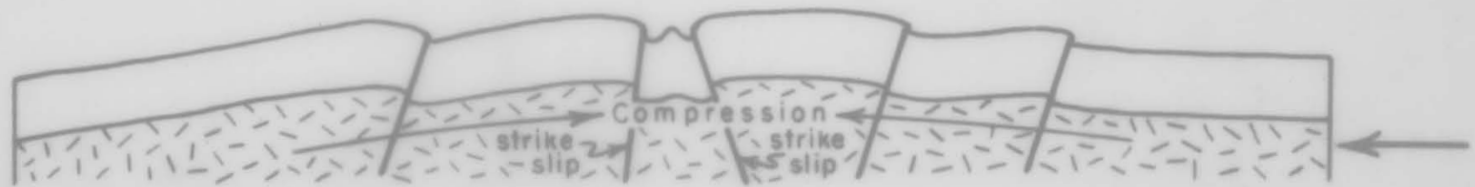

b. Crumpling of the dome with reversal of direction of throw on some faults and strike-slip movement on major shear foults.

Figure 23.--Diagrammatic cross sections showing hypothetical stages of development of an anticlinorium from an elongate dome. 
The upward deflection of compressional stresses in the dome

caused some of the earlier-formed normal faults to becor aigh-a) le reverse faults. Strike-slip movement along the earliex form $d$ ar faults would have allowed the Horse Lake and Willow Creek isenen blocks to be shoved toward each other as the wedge-shaped fecolote Mesa and Lagunas-Puente basement blocks were depressed and shoved slightly outward parallel to the axis of the dome. Thus, strike-slip movements on the shear faults would have accomplished transverse (northeast-southwest) shortening and slight longitudinal (northwestsoutheast) lengthening oi the dome. This could account for the northeast-southwest shortening implied by the geometry of the sharply-folded sedimentary rocks on the opposed flanks of the Horse Lake and Willow Creek anticlines, and the shortening implied by the configurations of Tecolote Mesa syncline and Lagunas and Puente domes. A mechanism of strike-slip as well as vertical movement between competent blocks of the uparched basement might have produced folds in the sedimentary rocks on other parts of the anticlinorium also, but it is beyond the scope of the present paper to discuss the mechanics of the other folds.

The writer concludes that the fault pattern and the symmetry of the Horse Lake and Willow Creek anticlines on the southeastern part of the Archuleta anticlinorium probably indicate that this part of the anticlinorium originated as a low, northwesterly elongated dome which was later deformed into an anticlinorium. The entire Archuleta anticlinorium 
seems to have been produced by the northeasterly compressional force which downbuckled the San Juan and Chama basins and caused the right shift on the Nacimiento and Gallina faults. Probably the main deformation was accomplished in two or more stages during Late Cretaceous and early Tertiary time, but some stages of faulting occurred later. According to Dane (1948) a few of the faults on the anticlinorium are younger than the Miocene(?) dike swarm crossing that feature, and may be of Miocene or Pliocene age. However, according to Wood, Kelley, and MacAlpin (1948), sills associated with the dikes in Colorado are not dis placed by the major faults that offset the Cretaceous rocks. The alinements of the dikes show little relationship to the structure of the eastern part of the San Juan Basin or the Archuleca anticlinorium, and their intrusion probably was related to stresses other than those which produced the basin and anticlinorium.

\section{Regional Structural Discontinuity}

The Nacimiento and Gallina faults and the eastern margin of the Archuleta anticlinorium mark a major regional structural discontinuity. The Nacimiento and Gallina faults are a sharp and easily recognized dis continuity, but north of the surface termination of the Gallina fault there is no single str ctisral fenture to delineate the discontinuity. However, the patterns of deformation a e cor siderably different on either side of a slightly curved ine projected north-northeastward from the northern 
termination of the Gallina fault. The folds and faults of the Archuleta anticlinorium certainly do not terminate abxuptly at the nozh-northe $i$ trending stippled boundary shown (on Fig. 12) as the eastern boundary of the anticlinorium north of the Gallina fault; nevertheless, many of the structures do terminate very near this boundary and the structural grain of the Chama basin at the southeast is dissimilar to that of the anticlinorium.

The line or band of discontinuity can be projected north-northeastward past the northwest-plunging end of the Brazos uplift but is lost beneath the rocks of the San Juan Mountains volcanic field in the vicinity of Cumbres Pass north of the New Mexicn-Colorado boundary. The total length of the discontinuity from the south end of the Nacimiento uplift to the vicinity of Cumbres Pass is almost 110 miles. The structural discontinuity is similar in its general alinement and position to a central segment of the Eastern Rockies trend (of Kelley and Clinton, 1960, fig.

9, p. 93)--a straight north-northeast-trending lineament drawn through the northern part of the Lucero uplift, the northern end of the Nacimiento uplift, and the northwestern end of the Brazos uplift.

Not only is the structural grain different on opposite sides of the discontinuity but, perhaps more importantly, differing major structures are opposed. Thus, where the Nacimiento uplift is opposite the San Juan Basin, the eastern side is structurally highest; whe re the Archuleta anticlinorium is opposite the Chama Basin the western side is structurally highest; and, farther north, where the Brazos uplift is opposite the 
northern part of the Chama Basin and the San Juan sag, the eastern side is again structurally highest (Fig. 24). The major st ructural uplifts on either side of the discontinuity seern to be more or less distinct structural blocks whose general outlines and orientations were deterrined, at least partly, by pre-Laramide events. The northexly alinement of the Nacimiento uplift is as old as Pennsylvanian or Permian (Renick, 1931, p. 14-19; Wood and Northrop, 1946; Read and Wood, 1947, p. 226, 232-234), and the northwesterly alinements of the Archuleta anticlinorium and Brazos uplift also are as old as Pennsylvanian or Permian (Dane, 1948; Read and others, 1949). Although Pennsylvanian rocks are absent from much of the anticlinorium and the uplifts, deep wells have shown that they are present in the San Juan and Chama basins.

The structural discontinuity is oblique to the reads of the major structures on either side, and the alinement of the Nacimiento fault diverges more from the direction of shortening of the San Juan Basin and Archuleta anticlinorium than does the alinement of the Gallina fault and the northern part of the discontinuity. This obliqueness suggests the rather ubvious conclusions that the basement rocks of the region are not homageneous and that they yielded differently during deformation, setting up local stresses which governed the formation of local structures. The Precambxian basement rocks of the Nacimiento uplift are mostly granite, where- as the Precambrian rocks of the Brazos uplift are mainly metasedimentary and metavolcanic rocks. Unfortunately, practically nothing is known 


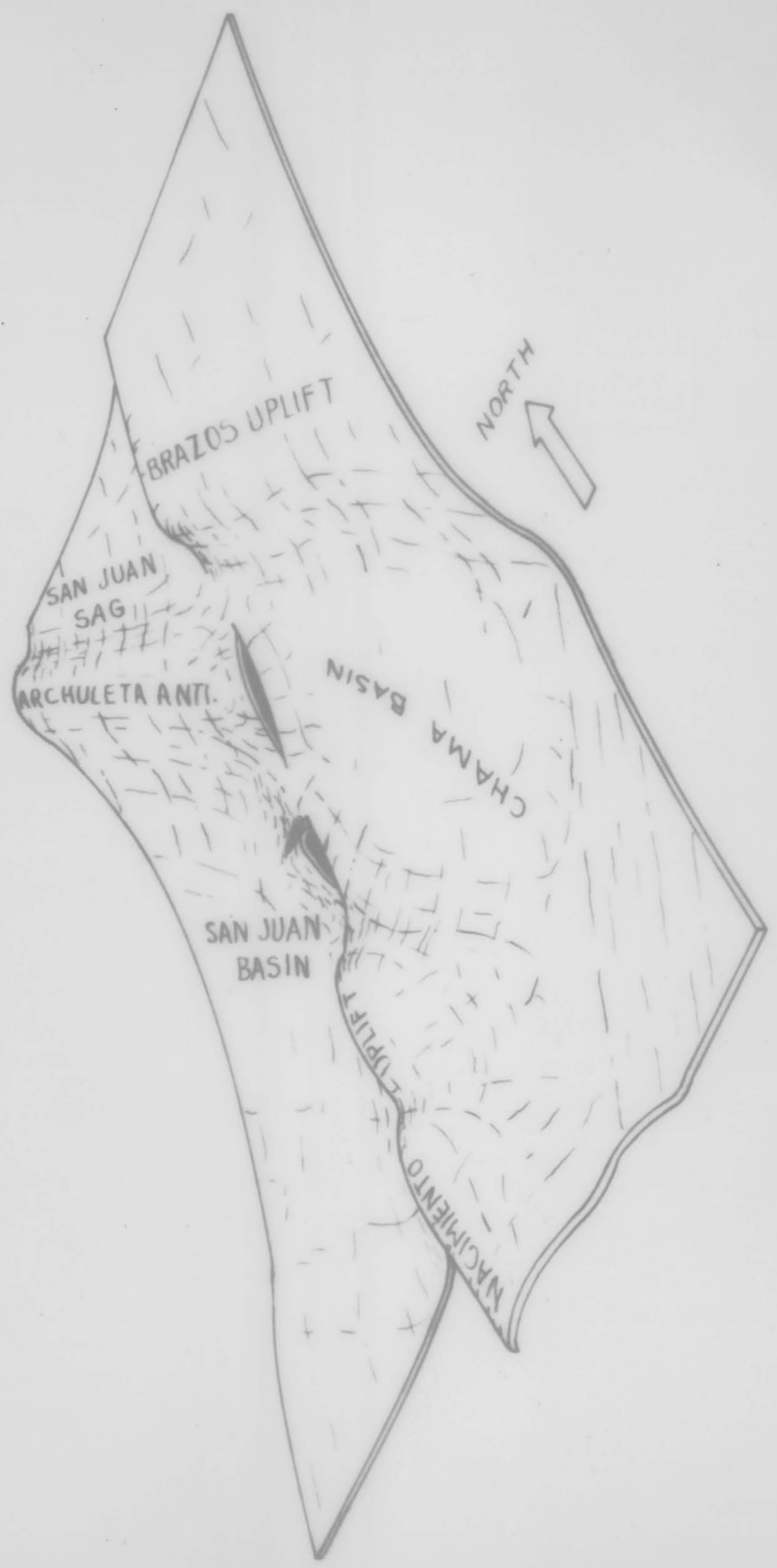

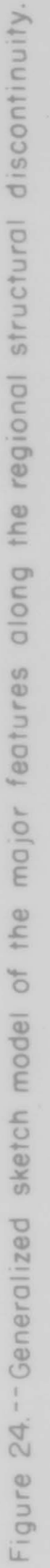


about the basement rocks of the Archuleta anticlinorium and he S Jua and Chama basins.

Where the regional structural discontinuity is the Nacimient an Gallina faults it is "real". Along the eastern side of the Archuleta anticlinorium the significance of the discontinuity is a matter of interpretation. However, the fact that the rocks are deformed differently on opposite sides of a line (or narrow band) leac's to the idea that the discnntinuity may represent a real feature such as the contact between rocks of differing structural competence, or a major zone of fracturing. This feature, if present, would have to be in the basement along the eastern side of the Archuleta anticlinorium inasmuch as the surface sedimentary rocks are the same on either side of the discontinuity, and at the surface the re are no known faults parallel to the discontinuity.

During Laramide orogeny the considerable structural competence of the massive granite of the northerly trending Nacimiento uplift block caused it to resist deformation by the regional northeast-southwest compressional force, and the uplift had a buttressing effect which partly accounts for the relatively minor deformation of the Chama basin region. The upward-bulging of the Nacimiento uplift and the slight downbuckling of the Chama basin region caused a small amount of northeast-southwest shortening, whereas the downbuckling of the northwesterly alined San Juan Basin and the upbuckling of the northwesterly alined Archuleta block caused a greater amount of northeast-southwest shortening. This 
difference in amount of shortening was accommodated main l by $-\mathrm{g} n$ ! shift along the Nacimiento and Gallina faulis. The folding and crumipling of the Archuleta anticlinorium that cause a small amount of shortening in a northeasterly direction would seem to necessitate some right shift between the anticlinorium and the Chama basin. If the shift took place along a deep-seated shear zone in the basement rocks, the overlying sedimentary blanket would have been twisted above the shear zone. The bend and increase in amplitude of the northern part of the Rio Chama anticline, and the southerly trend of some of the large faults northeast of El Vado might indicate twisting but the evidence is not conclusive. The Archuleta anticlinorium and the Chama basin are, in a sense, complementary features. The amount of northeast-southwest shortening of the upbuckled anticlinorium is of the same general magnitude as the amount of shortening of the downbuckled Chama basin; thus there was no geometric necessity for a large amount of lateral shift along the structural discontinuity north of the Gallina fault. Unfortunately, the northern parts of the Brazos uplift and the San Juan sag in Colorado are buried beneath the San Juan Mountains volcanic field and it is impossible to determine whether lateral shift occurred along the discontinuity in Colorado.

Although most of the regional compressional stress was relieved by buckling nearly at right angles to the stress, and by right shift on the Nacimiento and Gallina faults, part of the stress was transmitted across the oblique discontinuity to bulge the Nacimiento uplift and buckle up the 
northeasterly-trending western limb of the Charna basin along the French Mesa-Gallina uplift.

\section{Discussion}

The general oval or parallelogram symmetry of the San Juan Basin cannot be attributed to outward-directed compressional forces arising entirely from shortening and crowding within the basin as it subsided. The amount of subsidence was such that outward-directed compressional forces in the basement would have acted only during the initial phases of Laramide subsidence. During the remainder of the subsidence the basement of the Central basin would have been lengthened or would have subsided as a graben if it had not been under compression by a force directed toward the basin. The right shift along the Nacimiento and Gallina faults indicates that the basement rocks of the eastern part of the basin were shortened during the later stages of subridence, and this shortening seems to require that the subsidence was caused by northeasterly directed regional compression. This force probably produced both the basin and the surrounding uplifts.

Dallmus (1958, p. 907) has shown that the greatest compressional stresses in a subsiding basin are near the area of greatest depression of the basin. This is true whether the crust subsides in response to a principal vertical force, or in response to a principal tangential compressional force. Thus, the central part of a depressed segment of the 
crust is a favored location for intrabasinal and interbasinal arches

uplifts. The positions of the arches are governed, of course, by the positions of pre-existing zones of crustal weakness as well as by the position of maximum stress within a basin. The interbasinal San Juan dome and Archuleta anticlinorium lie partly on an ancient northwesterly trending 'uplift, , and are near the central part of the noxthwesterly trending Late Cretaceous basin whose northeastern margin was marked by the Uncompahgre-Sangre de Cristo geanticline (Fig. 10). Thus it seems likely that the dome and anticlinorium originated as an intrabasinal arch in the area of maximum compressional stress in the subsiding basin.

After the arch was formed the San Juan Basin and the San Juan sag seem to have been deformed semi-independently. The poorly defined semicircular shape of the northern rim of the Central basin probably is due partly to secondary outward-directed compressional forces caused by crowding in the Central basin as it was shortened and downbuckled. Also, the San Juan dome seems to have been upwarped as the Central basin was depressed, and the compensating effect of the radial expansion of the dome probably helped to define the curved northern rim of the basin.

Although an analysis of the structure of the eastern side of the San Juan Basin and adjacent uplifts indicates that the basin and uplifts were produced by regional tangential compression, the analysis does not 
indicate whether this stress was ultimately the result of a regional vertical principal force which caused the subsidence of a very large segment of the earth's crust. Possibly this segment might have been as* wide as the entire Cretaceous Rocky Mountain geosyncline. On the other hand, it is obvious that a regional compressional principal force could produce local secondary vertical forces. In this connection it should be noted that the linear uplifts and basins east and north of the San Juan Basin follow a regional pattern of curving uplifts concave to the southwest. On the eastern side of the Uncompahgre-Sangre de Cristo geanticline, the Sangre de Cristo Mountains were the site of overthrusting in Paleocene and Eocene time (Burbank and Goddard, 1937; Johnson, Dixon, and Wanek, 1956; Baltz and Bachman, 1956; Wanek and Read, 1956). The northern part of the Sangre de Cristo uplift bends northwestward and merges, more or less, with the northwesterly trending uplifts such as the Gunnison and Uncompahgre uplifts in the northeastern part of the Colorado Plateau. These relations suggest that a segment of the earth's crust comprising the Colorado Plateau may have shifted north-northeastward and encroached upon the region to the north and east (or vice versa), generating a regional tangential compressional stress.

Thus, it would appear that, although analyses of the mechanics of formation of individual basins can more or less demonstrate the forces that produced the basins and adjacent uplifts, the analyses cannot conclusively demonstrate the ultimate nature of the regional forces involved. 
It is unlikely that the ultimate causes of regional stresses in the earth's crust will be determined and understood until the local mechanics of deformation of all parts of large regions have been analized thoroughly.

\section{DEPOSITIONAL AND TECTONIC HISTORY}

On the basis of stratigraphic relations determined in the mapped area and elsewhere in northwestern New Mexico and southwestern Colorado, some of the stages of Laramide deformation of the San Juan Basin and some of the adjacent uplifts can be dated. In late Montana time, during deposition of the Pictured Cliffs sandstone and the Fruitland and Kirtland formations, the Uncompahgre-Sangre de Cristo geantıcline (Fig. 10) rose to define the northeastern limb of a northwesterly trending basin that included the area of the present San Juan Basin but was larger than the present basin. The area of the Nacimiento uplift may have been a shoal at this time. Near the end of Cretaceous time the San Juan Basin began to be formed. Prior to deposition of the Ojo Alamo sandstone, low northwesterly trending folds began to be formed in the adjacent parts of the present San Juan Basin and Nacimiento uplift. This folding may indicate a small amount of shift between the San Juan Basin and the Nacimiento uplift, but the strustural relief between the two probably was small. The Archuleta anticlinorium probably began to be formed during deposition of the Mancos shale, and before the end of Cretaceous time it was uplifted to form an intrabasinal arch, thus beginning the delineation of 
the San Juan Basin and the San Juan sag. The Hogback monocline on the northwestern side of the Central basin probably began to be formed prior to deposition of the Ojo Alamo.

During Paleocene time the Uncompahgre-Sangre de Crisıo geanticline (probably including part of the Brazos uplift) contributed a large amount of orogenic and volcanic detritus to the San Juan Basin region. The Nacimiento uplift, Archuleta anticlinorium and Chama basin may have undergone some deformation, but they were parts of the same depositional basin in which the Nacimiento and Animas formations accumulated. The Animas formation seems to have been deposited across the Archuleta . anticlinorium and is present in the San Juan sag in the southern part of the San Juan Mountains. No unconformities were found within the Nacimiento formation on the eastern side of the basin and it is probable that the Nacimiento and Animas formations were deposited across the region of the Chama basin and Nacimiento uplift. Parts of the Nacimiento and Animas formations were deposited on the Four Corners platform west of the Central basin, but intraformational unconformities indicate that folding continued episodically along the Hogback monocline during early and middle Paleocene time. In latest Paleocene or earliest Eocene time the entire Central basin was downwarped and the northwesterly trending anticlines at the eastern side of the basin and adjacent part of the Nacimiento uplift weré rejuvenated and folded sharply. The basin may have been depressed slightly relative to the Nacimiento uplift during the right shift which 
produced the folds.

In early Eocene time the Uncompangre-Sangre d Cris geant line contributed a large amount of arkosic detritus to the San Juan Bayin region. These sediments of the Cuba Mesa member of the San Jose formation rest unconformably on the Nacimiento formation on the western, southern, and eastern margins of the Central basin, but the San Jose and Nacimiento probably are conformable in the interior of the basin. During deposition of the Regina member of the San Jose formation, differential vertical movements defined the eastern edge of the Central basin as the basin was depressed relative to the Nacimiento and French Mesa-Gallina uplifts. The first stage of deformation was the production of a westfacing monocline along the western side of the uplift. Large volumes of Cretaceous and older sedimentary rocks were eroded from the Nacimiento uplift although the Precambrian core does not seem to have been exposed at this time. Probably the Paleocene and latest Cretaceous rocks were eroded also from the main part of the Archuleta anticlinorium and the San Juan dome and the detritus was deposited in the San Juan Basin. The Precambrian terrane of the Brazos uplift contributed a large volume of coarse detritus (Llaves member of the San Jose formation) to the deeper part of the San Juan Basin. Folding continued episodically on the Hogback monocline on the northwestern side of the Central basin in early Eocene 1

- time. During a period of relative tectonic quiescence the San Juan Basin 
was filled by sediments of the San Jose formatzon which lapped out of the basin and onto the flanks of the adjacent uplifts (Telluride conglomerate, Blanco Basin and El Rito formations) as the source areas were worn down by erosion.

Post-San Jose (probably Eocene or Oligocene) deformation was attended by the main movements along the Nacimiento and Gallina faults during further depression and northeastward shift of the Central basin. - The San Jose formation was tilted inward along the margins of the entire Central basin. The San Jose formation and older rocks were uplifted and tilted along the western side of the Archuleta anticlinorium, causing the axis of the basin to be defined in its present position in the Central basin as the arch was deformed into an anticlinorium.

The Brazos uplizt and the eastern part of the Nacimiento uplift were tilted eastward after Oligocene or early Miocene time, as shown by the fact that the El Rito and Abiquiu formations (of Smith, 1938) in the Brazos uplift and in the northeastern part of the Nacimiento uplift are tilted eastward. This tilting probably occurred in Miocene and Pliocene time and was accompanied by strong faulting along the eastern margins of the uplifts during the formation of the Rio Grande trough. The eastward-tilting of the uplifts that lie east of the San Juan Basin might have caused slight stretching in the eastern part of the basin. This stretching could have selectively opened certain earlier-formed fractures such as those into which the lamprophyre dikes were intruded in Miocene(?) 
time in the northeastern part of the basin and on the Archuleta anticlinorium. Structural adjustments have taken place in the southeastern part of the Nacimiento uplift as recently as Pleistocene and Recent time as shown by the fact that the Bandelier rhyolite tuff (of Smith, 1938 ) has been broken by normal faults (Wood and Northrop, 1946; Northrop, 1950, p. 41-42).

\section{PRINCIPAL CONCLUSIONS}

During the mapping and study of the subsurface geology of the east-central part of the San Juan Basin, it was determined that several Late Cretaceous rock units are more extensive than indicated in previous reports. The Picture Cliffs sandstone and the undivided Fruitland formation and Kirtland shale were traced along the eastern side of the basin more than thirty miles north of the positions where they had been reported to wedge out into the Lewis shale. The Pictured Cliffs changes laterally into a thin equence of shaly sandstone and sandy shale that can be traced to the northeastern part of the area where it finally becomes indistinguishable from the upper part of the Lewis shale. The FruitlandKirtland sequence, which contains northward-thickening marine or brackishwater sandstone as well as nonmarine sandstone and shale, does not wedge out and was traced across the entire area.

The Fruitland-Kirtland sequence is overlain unconformably by the Ojo Alamo sandstone in the east-central part of the San Juan Basin. The unconformable relationship indicates that low folds were developed on the 
eastern side of the basin prior to the deposition of the Ojo Alamo. The Ojo Alamo has been considered to be Cretaceous by most workers because a locally present unit of dinosaur-bearing shale was assigned to the lower part of the formation at its type locality. However, the persistent sandstone which constitutes the upper part of the Ojo Alamo at it sype locality probably is unconformable with the underlying dinosaur-bearing shale. The persistent upper sandstone is correlated with the Ojo Alamo of the east-central and western parts of the basin, and meagre florules indicate that the Ojo Alamo sandstone (excluding the dinosaur-bearing shale at the type locality) is early Tertiary.

The Ojo Alamo sandstone is overlain conformably by the Nacimiento formation of Paleocene age. No evidence of unconformity was observed at the base of the Nacimiento in the east-central part of the basin although previous workers have postulated that the contact is an unconformity on the southwestern and western sides of the basin. The Nacimiento formation is overlain unconformably by the San Jose formation of itrly Eocere age. Physical evidence oubstantiates the unconformity postulated previously on paleontologic evidence by Simpson. The variations in thickness of the Nacimiento formation indicate that a system of northwesterly-trending folds developed along the eastern side of the San Juan Basin prior to the deposition of the San Jose formation.

The San Jose formation consists of several mappable facies which were named the Cuba Mesa, Regina, Llaves, and Tapicitos members. An 262 
intraformational angular unconformity between the Regina member and older rocks near the eastern edge of the basin indicates that a monocline began to form on the western side of the Nacimiento uplift in early Eocene time. The overstepping Regina beds are folded also, and this indicates that much of the structural relief between the basin and uplift is the result of movements on the Nacimiento fault after the deposition of the San Jose formation.

The stratigraphy and structure of the mapped area provide evidence concerning the nature of the Laramide deformation of the entire eastern part of the San Juan Basin and the adjacent uplifts. The north-trending Nacimiento fault and the northeasterly-trending Gallina fault are highangle wrenches along which right shift occurred during downbuckling and shortening of the basin in response to a northeasteriy-directed regional compressional force. The southeastern part of the Archuleta anticlinorium was upwarped and shortened by the same compressional force. The Nacimiento and Gallina faults and the southeastern margin of the Archuleta anticlinorium mark a major north-northeast-trending structural discontinuity along which differing major structures are opposed. The variations in structure on either side of the discontinuity appear to be the result of differential yielding to the regional compressional stress by crustal blocks whose alinements and structural competence are different. 


\title{
DESCRIPTIONS OF \\ STRATIGRAPHIC SECTIONS OF \\ TYPE LOCALITIES
}

\section{Index}

\begin{abstract}
Pages
Nacimiento formation. . . . 265-269
\end{abstract}

San Jose formation:

Cuba Mesa member. . . . 273-276

Regina member ..... 278-281

Llaves member, lower part . . 282-283

Llaves member, upper part . . 285

Tapicitos member, lower part. . $\quad 286$ 
Localities la-1d, composite section, T. 20 N., R. 2 W. Units $1-13$ measured at locality 1 a on the south side of the small butte in the SE $1 / 4 \mathrm{SW} 1 / 4 \mathrm{sec}$. 25 . Units $14-31$ measured at locality $1 \mathrm{~b}$ on the topographic spur projecting eastward from Mesa Portal in the SW $1 / 4 \mathrm{NW} 1 / 4 \mathrm{sec}$. 25 and the NE $1 / 4 \mathrm{sec} .26$. Units $32-52$ measured at locality lc on the mesa north of Arroyo Chiuilla in the NE 1/4 NE 1/4 sec. 23 , and the SE $1 / 4$ sec. 14. Units $53-95$ measured on the SW side of a spur of Mesa de Cuba at locality ld in the NW 1/4 SW 1/4 sec. 12 , and NE $1 / 4 \mathrm{sec} .11$.

Top

San Jose formation:

Thickness

(feet)

Cuba Mesa member (in part):

95. Sandstone, light-tan to brown. Fine-grained to very coarse grained quartz with 10 percent pink feldspar. Contains many granules and pebbles composed mainly of quartzite. Cross bedded, beds $1-15$ feet thick. Contains silicified wood. Lower two-thirds forms nearly vertical ledges; upper one-third forms rounded ledges at the top of the southern part of Mesa de Cuba. . . . . . . . . . . . 140

94. Sandstone, lightmgray, shaly. Forms notch.

$E$ zosional contact with overlying unit . . . 6

93. Sandstone, light-tan, fine-grained to very coarse grained. Composed of angular to subround quartz with some rock fragments and a trace of muscovite. Forms thin, notched, rounded ledges... . 30

Nacimiento formation:

92. Steep slope mostly covered by talus from above units. Gray to olive-green silty clay shale is exposed at a few places. Upper 50 feet is a boulderstrewn bench. . . . . . . . . 100

91. Shale, silty clay, gray and olive-green; fcrms steep slope. . . . . . . . . 16

90. Lignite, dark-gray, silty and argillaceous; forms conspicuous band. . . . . . . . 3

89. Shale, silty and sandy, light olive-green. . . 30

88. Sandstone, light-brown, medium-grained, soft, and channel cross-bedded. This unit thickens southwestward and forms a strong ledge. . . 
Nacimiento formation - Continued

87. Shale, sandy and silty clay, light olive-gray with a few purple bands. Near the middle of the unit is a yellow sandstone lens four feet thick. . . 68

86. Clay, purple, with interbedded olive-green sandy siltstone; forms steep slope. . . . . . . . 12

85. Sandstone, light-buff to light olive-green; fineto medium-grained and argillaceous. Forms soft rounded slope........... 13

84. Siltstone, olive-gray and purple, and interbedded clay. Near the middle is a lens of ferruginous sandstone, 2 feet thick. Unit forms a steep, fluted slope. . . . . . . . 30

83. Sandstone, light-brown, medium-grained; forms a vertical ledge. . . . . . . . . . .

82 Sandstone, fine-grained, argillaceous, slopeforming. . . . . . . . . . . . . 8

81. Shale, silty clay, olive-green, sandy. . . . 5

80. Clay, purple, slope-forming. . . . . . . 4

79. Sandstone, light-buff, fine-to mediu -graint soft. Contains gray clay lens.

78. Shale, silty clay, olive-gray with purpe bands Contains very thin beds of soft yellow s andstone. Forms a steep, fluted, irregular slope.

77. Shale, gray clay; and buff, fine - to mediumgrained sandstone. . . . . . . . . 6

76. Claystone, light-purple; interbedded soft sandstone and olive-gray siltstone. Forms a small bench. . . . . . . . . . . . 13

75. Siltstone, olive-green with purple bands. Soft white sandstone 3 feet thick occurs near the middle. Unit forms a soft slope. . . .

74. Siltstone, argillaceous, light yellowish-gray. .

73. Sandstone, light-brown to $\tan$, medium-grained; contains pink rock fragments and black grains. Sandstone is cross bedded and contains thin stringers of gray shale. Unit is mostly soft, but some beds form small vertical ledges. .

72. Shale, silty clay, light olive-green. Upper part is sandy and contains lignite shale and silicified wood. Unit forms a rounded hill. . . . 26

71. Lignite, black to dark-brown; forms a conspicuous band above a small bench. . . . . . . 3 
Nacimiento formation - Continued

70. Claystone, bentonitic, olive-gray; forms a soft slope on the lower part of a bench. . . 2.5

69. Siltstone, shaly, yellowish-gray; forms a soft slope. . . . . . . . . . . 8

68. Sandstone, buff to yellowish-brown, fine-to coarse-grained, argillaceous; forms a soft, rounded to vertical cliff. . . . . . . .

67. Shale, light olive-gray; contains several beds of sandstone 2-7 feet thick and forms a soft, smooth slope. . . . . . . . . . . .

66. Sandstone, light-buff to yellowish-brown, fineto medium-grained; forms a rounded ledge. .

65. Shale, silty, light olive-gray; contains stringers of nodular ironstone and bands of dark olive green bentonitic clay. Unit forms a soft, rounded slope. . . . . . . . . .

64. Sandstone, light-gray, similar to unit 62 below. Unit is lenticular and locally merges with unit 62. This sandstone is the upper bed of a zone characterized by soft, white-weathering sandstone and interbedded gray shale. . . . . . 14

63. Shale, silty clay, medium- to dark-gray, lenticular. . . . . . . . . . . . .

62. Sandstone, light-gray, stained yellow-brown; composed of very fine grained to coarse-grained quartz with a few pink, yellow, and black rock fragments and feldspar grains. The unit grades laterally into shale, and forms a soft, rounded, fluted, steep slope. . . . . . . . 25

61. Shale, light olive-gray to dark-gray; forms a small rounded bench. . . . . . . . .

60. Coal and dark-gray carbonaceous shale; forms conspicuous notch. This bed was traced northwestward from exposures near the Torreon road into the deep canyon on the south side of Mesa de Cuba where units 61-95 were measured. . . . 0.5

59. Siltstone, slightly sandy, dark-brown. . . . . 3

58. Siltstone, shaly, light olive-gray. . . . . . 6

57. Claystone, slightly sandy, dark purplish-gray; forms a dark irregular band on the slope. . . 5.5 
Nacimiento formation - Continued

56. Siltstone, argillaceous, light-gray; contains several thin stringers of white-weathering lenticluar sandstone. . . . . . . 20

55. Claystone, purple. .. . . . . . . . 1

54. Sandstone, argillaceous, gray-white; forms an irregular band on a steep slope. . . . . .

53. Siltstone, shaly, light gray; forms a steep fluted slope north of the Torreon road east of a cattleguard.

52. Sandstone, light-brown, very argillaceous, thinbedded. The unit forms a soft slope near the top of a gravel-capped butte in sec. 14, T. $20 \mathrm{~N}_{\mathrm{o}}$, R. $2 \mathrm{~W}$. Units 51 and 52 dip northward $2^{\circ}-2^{\circ}$ and seem to be equivalent to a white sandstone below unit 53 just north of the Torreon road.

51. Sandstone, very light-tan; weathers almost white. Sandstone is fine to medium grained, argillaceous, soft, and slope-forming. . . . . . . . 7

50. Siltstone, shaly, argillaceous, dark-gray. . . . 3

49. Sandstone, silty, shaly, light-gray, very fine grained; slope-forming.

48. Clay, silty, gray; light-gray weathering, slope forming. . . . . . . . . . .

47. Sandstone, light-gray, very fine grained, argillaceous, shaly; forms a slight, rounded ledge.

46. Clay, silty, light-gray to olive-gray with a purplish band; slightly bentonitic. . . . . . .

45. Sandstone, very light-olive, weathering almost white. Sandstone is very fine grained and argillaceous. . . . . . . . . . . .

44. Siltstone, shaly, gray .

43. Clay, dark-gray.

42. Sandstone and sandy shale, olive-drab, argillaceous.

Unit weathers to light yellowish-brown slope...
41. Clay, similar to unit 39. . . . . . .

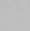

40. Sandstone, gray-white, fine-grained, argillaceous, soft. . . . . . . . . . . . .

39. Clay, light olive-gray . . . . . . . . .

38. Sandstone, gray-white, fine-grained, argillaceous, soft.

37. Clay, light olive-gray. . . . . . . . .

36. Sandstone, gray-white, fine-grained, argillaceous, soft. 
Nacimiento formation - Continued

35. Clay; mainly drab gray with some purplish and olive bands, and some siltstone stringers. The unit forms soft rounded slopes on a butte. . .

34. Siltstone, argillaceous, light brownish-gray; contains stringers of yellowish sandetone, and forms a slope.

Total thickness of Nacimiento formation.

Ojo Alamo sandstone:

33. Sandstone, yellowish-brown, argillaceous, fineto me dium-grained, shaly-bedded, soft; forms poorly exposed rounded slopes. . . . . . .

32. Sandstone, light-buff, medium- to coarsegrained; concave cross bedding. Unit forms moderately strong, smooth ledges retreating from unit 31 on the north side of Arroyo Chivilla. Unit 31 was correlated from the south side of Arroyo Chiuilla. . . . . . . . . .

31. Sandstone, fine - to coarse-grained, with granules. A thin stringer of carbonaceous shale occurs near the base. The unit forms low rounded hills on the northeastern part of Mesa Portal.

30. Sandstone, yellowish-brown; coarse-grained to granules; mostly angular to subangular quartz with fragments of feldspar common. Locally at the base of this unit is a lense of channel-filling gravel composed of small pebbles of quartz, chert, clay, and feldspar. Flattened carbonized logs are present in the gravel. The unit forms a strong cliff, and thickens south of the locality of meas urement. The base of the unit is an irregular erosional surface. . . . . . . . . Total thickness of Ojo Alamo sandstone. . . . $\frac{27.5}{69.0}$

Kirtland shale and Fruitland formation, undivided:

29. Sandstone, light-brown, fine- to coarse-grained; grades into underlying unit and weathers to a notch.

28. Clay, purplish-gray; forms low rounded slopes..

27. Shale, sandy and silty, olive-gray; forms rounded slopes. . . . . . . . . . 
Kirtland shale and Fruitland formation, undivided - Continued

26. Sandstone, very light gray to buff; weathers

light orange-brown. Sandstone is composed

of fine-grained to very coarse grained, an-

gular to subangular quartz with a minor amount

of weathered feldspar and rock fragments. The

sandstone is ferruginous and contains nume rous casts of logs. Bedding is irregular, and an ironstone layer 1-3 feet thick occurs near the top of the unit. The unit forms a blocky vertical cliff. . . . . . . . . . . . . . .

25. Siltstone and very fine grained sandstone, interbedded. The lower half is olive-green; the upper half is banded gray, brown, and purple. The unit forms nodular-weathering notch.

24. Shale: purple and olive; upper part is silty and grades into the overlying unit. . . . . . .

23. Sandstone, light-gray, tan-weathering; composed of silt to very coarse grained quartz, a few grains of black minerals and rock frags, and a few clay pebbles. About 20 feet above the base is a dark-brown concretionary layer. The unit is cross bedded and forms a vertical ledge. . .

22. Sandstone, brown to white, medium-grained, argillaceous; weathers to a notch. . . . . . 1

21. Sandstone, olive-gray, fine-to me dium-grained, slope-forming. . . . . . . . . . 18

20. Shale, light olive-gray; contains plant fragments.. 1.5

19. Sandstone, buff, fine-grained, argillaceous; forms a small rounded ledge. . . . . . . 3.5

18. Clay, similar to unit 16. . . . . . . . 8

17. Sandstone, very light-brown, fine-grained to very fine grained, argillaceous and micaceous; forms a rounded ledge with a gray shale stringer near the middle.

16. Clay, banded olive-green and purple, slightly bentonitic; forms smooth, rounded, fissured hills.

15. Sandstone, very light gray to white, fine-to medium-grained. Sandstone is composed of angular to subround quartz with a trace of pink and green chert and black minerals; forms a rounded soft slope at the eastern end of a spur.. 
Kirtland shale and Fruitland formation, undivided - Contint d

14. Sandstone, similar to unit 13 but softer; rests on pink sandstone equivalent to unit 13 on a small cuesta crossed by a road. . .....

13. Sandstone light-gray to light-buff to white; medium - to coarse-grained, with some granules. The sandstone is composed of angular to subround quartz with some rock fragments and contains pebbles of sandstone and red and gray siliceous rocks. Much silicified wood is present, with some logs as large as 2 feet in diameter. The sandstone is strongly cross bedded and forms a strong ledge capping an isol ated butte . . . . . . . . . . .

12. Sandstone, light olive-gray to buff, fine- to medium-grained; contains argillaceous string ers and forms a slight, rourded ledge on the butte. . . . . . . . . . .

11. Sandstone, medium-gray, fine-to medium-grained, argillaceous. The sandstone contains many flattened lignitized logs and a lignite band at the base. The sandstone contains stringers of gray clay with lignitized plani fragments. To the southwest this unit forms a prominent, persistent carbonaceous zone on the escarpment of Mesa Portal. . . . . . . . . . .

Total thickness of Kirtland shale and Fruitland formation.

Pictured Cliffs sandstone:

10. Sandstone, light-gray, medium-grained. The sandstone is composed of angular to subangular quartz with a few pink and black grains and black mica flakes. The unit is slightly gypseous and ferruginous, and forms a steep slope. . . . . . . . . . . . .

9. Shale, fissile clay, dark-gray; poorly exposed on a slope. . . . . . . . . . . .

8. Sandstone, light olive-gray, fine-grained to very fine grained. About 30 percent of the unit is clay shale in beds 2 inches-1 foot thick. The unit is poorly exposed on a slope. . . . . .

7. Covered. Probably shale. . . . . . . . 


\section{Pictured Cliffs sandstone - Continued}

6. Sandstone, light olive-gray, fine-grained to very fine grained. The lower part is poorly cemented and forms a soft slope. The upper part is "papery-bedded", brown-weathering sandstuge. . . . . . . . . . . . . . .

5. Shale, clay, olive-green, poorly exposed...

4. Sandstone, fine-grained, soft, similar to unit 2 ; poorly exposed. . . . . . . . .

3. Sandstone, buff, medium-grained; contains black grains; cross-bedded. The weathered surface is a ferruginous brown rind one-eighth inch thick, and the beds have a slightly concretionary appearance. The sandstone contains Halymenites and pelecypods, and forms small ledges fapping benches. Locally the unit forms slopes. . . . . . . . . . . . .

2. Sandstone, light yellowish-brown, fine-grained to very fine grained, silty. Upper half contains three 6-inch stringers of gray shaie. The unit

forms a rounded slope. . . . . . . . Total thickness of Pictured Cliffs sandstone. : $\frac{7.5}{64.5}$

Lewis shale (in part):

1. Shale, silty clay, light olive-gray to gray; contains scattered tiny carbonized plant fragments. The unit is poorly exposed on a slope. . . . . 15+

Locality 2. Outcrops along State Highway 44 northwest of Cuba, New Mexico. Section measured mainly on the north side of the road. The base of the section is in the NE $1 / 4 \mathrm{NW} 1 / 4$ sec. 20 , and it was measured westward across secs. 17, 8, 7, and 6, T. 21 N., R. I W. , and secs. 1 and $2, T, 21 \mathrm{~N},$, R. $2 \mathrm{~W}$. The thickness of unit 30 in secs. 28 and 33-35, T. 21 N., R. 2 W., was estimated from topographic maps.

Top

Thickness

San Jose formation: (feet)

Llaves member(?):

31. Sandatone, buff, massive. The unit caps a mesa on the Continental Divide. Top eroded. . . . 


\section{San Jose formation - Continued}

Regina member:

30. Shale, sandy silty clay; gray with reddish, yellow, and white bands. Lenses of soft, argillaceous, fine-to coarse-grained, buff sandstone are interbedded, and most of the unit forms soft slopes and low rounded hills. Several ledge-forming, thick beds of sandstone are interbedded with variegated sandy shale. The highest part of unit exposed along the Continental Divide in secs. 28 and 29, T. 22 N., R. $2 \mathrm{~W}$. is predominantly reddish shale with thick lenticular sandstone interbedded. . .

Cuba Mesa member (type section), upper tongue $\left(\mathrm{T} \mathrm{sc}_{4}\right)$ :

29. Sandstone, rusty-brown to buff-weathering. The sandstone is composed of coarse-grained to granule-size angular to subrounded quartz, with some feldspar. The upper part of sandstone is a hard, rusty, ferruginous zone. The unit thins northward, but thickens southwestward and merges with unit 22 as units 23-28 wedge out. . . . $52 \pm$

Regina member, tongue ( $\mathrm{Tsr}$ ); wedges out to southwest:

28. Shale, silty clay, olive-gray, reddishweathering. . . . . . . . . . .

27. Sandstone, olive-green, fine - to mediumgrained, soft, argillaceous. . . . . . 9 9

26. Covered. Probably shale. . . . . . . 7

25. Sandstone, light-orange to buff; composed of very coarse grained to granule-size quartz, with some feldspar. The unit forms a slope in road cut.

24. Sandstone, buff, fine-to medium-grained; caps a small hill and forms an irregular ledge. .

23. Shale, sandy and silty clay, greenish-gray to olive-green with purple-weathering bands. . 
Cuba Mesa member ('type section), tongue ( $\mathrm{Tsc}_{3}$ ):

22. Sandstone, light yellowish-orange; composed of fine-grained to granule-size, angular to subround quartz with feldspar and rock frag ments. The unit forms a strong ledge. The lower half is composed of several streamchannel sandstones with thin interbeds of gray shale. The upper half is more massive. The unit wedges out to the northeast, but thickens to the south and merges with unit 18 as unit 19

21. Covered. wedge $s$ out. . . . . . . . . . . . 80

20. Sandstone, rusty-brown, very coarse grained; gray shale interbedded. . . . . . . . 5

Regina member, tongue ( $\mathrm{Tsr}$ ); wedges out to solith:

19. Shale, gray, soft; contains thin beds of soft sandstone. The unit forms a slope on the high hill north of State Highway 44... . . . . . 55

Cuba Mesa member (type section), main part:

18. Sandstone, buff, stained yellowish-brown; coarsegrained, cross-bedded, forms smooth rounded ledges north of State Highway 44 west of Rito de los Pinos. This unit is the upper part of the lower tongue $\left(\mathrm{Tsc}_{2}\right)$ of the Cuba Mesa member north of the locality of measurement. . . . . 47

17. Sandstone, soft and shaly, with carbonaceous shale interbedded.

16. Sandstone, yellow and buff, very coarse grained and pebbly; cross-bedded,forms rounded ledges. . . . . . . . . . . . .

15. Sandstone, gray and yellow, soft. Lenses of shale are interbedded.

14. Shale, clay, gray and carbonaceous; shaly sandstone interbedded. The shale contains many silicified logs, and forms a long, low slope. .

13. Sandstone, yellow and buff; very coarse grained with granules and small pebbles. The sand is mainly angular to subangular quartz, but is arkosic and micaceous. Unit has sweeping cross beds and forms irregular, rounded ledges. Large silicified logs are numerous. . . . . 
San Jose formation - Continued

Cuba Mesa member (type section), main part - Continued

12. Shale, gray, carbonaceous; forms a poorly exposed slope above lowest sandstone ledge we st of Rito de los Pinos. . . . . . .

11. Sandstone, yellow-buff; coarse - to very coarse grained, arkosic. Contains many silicified logs. Upper 1-2 feet is ferruginous ironstone. The unit caps the top of the hill north of State Highway 44 in the northern part of sec. 29, T. 21 N., R. $1 \mathrm{~W}$. The top of the unit seems to be equivalent to the top of the lowest sandstone ledge west of Rito de los Pinos. This unit and underlying units are mainly equivalent to the basal part ( $\mathrm{Tsc}_{1}$ ) of the Cuba Mesa member further north. . . . . . . . . .

10. Sandstone, orange-brown, coarse - to very coarse grained; forms a small poorly exposed ledge. .

9. Sandstone, light yellowish-brown, coarse-to very coarse grained, arkosic. The unit is similar to unit 7 , and forms an irregular slope capped by a hard ferruginous band.

8. Shale, clay, olive-gray. The lower 5 feet is slightly purplish weathering, brown, lignitic shale. The unit forms a soft slope. . . . .

7. Sandstone, light brownish-gray; composed of very coarse grained to granule-size subangular to subround quartz and quartzite with abundant feldspar fragments and lenses of small pebbles. The cross beds are broad and sweeping. Forms an irregular, rounded, retreating ledge. The upper 1-2 feet is highly ferruginous. . . . . 36

6. Sandstone, buff; weathers rusty-brown to red. Similar to unit 5. Cross bedded, forms ledge.. 27.5

5. Sardstone, buff, has a slight rusty stain. The sand is fine - to very coarse grained, angular to subround quartz with a trace of pink chert, feldspar, and mica. A few clay and quartzite pebbles are present in the upper half. The unit is cross bedded, and forms a strong cliff. Some bedding planes are marked by brown carbonized leaves and other plant debris. . . . . . 50 
Locality 2 - Continued

San Jose formation - Continued

Cuba Mesa member (type section), main part - Continued

4. Sandstone, buff to brown, fine-grained; and shaly

siltstone, gray to light olive-gray. Sandstone and shale are interbedded in beds 1 inch to 1 foot thick. The shale is lignitic. Unit forms a nearly-vertical slope. . . . . . . .

3. Sandstone, greenish-gray, light-to dark-brown weathering. The sand is medium - to coarse grained, angular to subround quartz with some pink and black chert fragments, feldspar, and mica. The unit contains shale pebbles near the base, and several shale lenses.

Forms a strong ledge. . . . . . . . .

2. Sandstone, gray; and interbedded gray and brown argillaceous siltstone. The unit seems to be a channel fill. About 30 percent of the unit is sandstone in beds 1 inch to 1 foot thick. The siltstone beds contain much lignitized plant debris. Forms small, irregular ledge. Erosional contact with underlying unit. . . . . Total thickness of Cuba Mesa member(including tongues of the Regina member)

Nacimiento formation (in part):

1. Shale, silty clay, olive-gray. Dark-gray

carbonaceous clay is about 12 feet below the top of the unit. Unit forms soft slope. Erosional contact with unit 2. . . . . . . . . Not measured 
Locality 3. Units 1-15 measured at locality 3 a on hogback: and slopes west of State Highway 112 in the SW 1/4 NE 1/4 sec. 31 . T. 25 N., R. 1 E. Base of section is on shale slopes north of U.S. Forest Service fence. Units 16-56 measured at locality $3 \mathrm{~b}$ in the valleys and on the steep escarpment in the SW 1/4 SW 1/4 sec. 31 , T. 25 N., R. 1 E.; and the N 1/2 SE $1 / 4$ and the SW $1 / 4 \mathrm{NE} 1 / 4 \mathrm{sec}$. 36, T. 25 N., R. $1 \mathrm{~W}$.

Top

Thickness

San' Jose formation:

(feet)

Llaves member:

56. Sandstone, gray to buff, coarse-grained and conglome ratic; contains some interbedded red shale, especially in lower half. The unit caps the highest part of the mesa. The upper beds probably are equivalent to the persistent medial sandstone of the Llaves member. Top eroded. . 160

55. Sandstone, light-gray; very coarse grained to granule-size quartz with some feldspar. The unit forms a rounded ledge at the top of the ridge south of a saddle. . . . . . . .

54. Shale, sandy silty clay, reddish-and green-gray; slope-forming. . . . . . . . . . . . 14

53. Sandstone, buff, fine- to coarse-grained; forms small ledges. . . . . . . . . . .

52. Shale, silty clay, reddish-and green-gray; slopeforming. . . . . . . . . . . . .

51. Sandstone, light-tan, medium-to coarse-grained; contains granules. Shaly sandstone of middle third of unit causes a break in slope separating rounded, irregular ledges.........

50. Siltstone, light greenish-gray, argillaceous; slope-forming. . . . . . . . . . .

49. Sandstone, tan, fine - to very coarse grained; contains lenses of pebbles consisting of gray and purple quartzite. Pebbles are 3-4 inches in largest dimension. The unit forms strong multiple ledges. . . . . . . . . .

48. Shale, greenish-gray with a red band near the base. . . . . . . . . . . . .

47. Sandstone, $\tan$ with pinkish cast, fine- to coarsegrained, arkosic; contains small quartzite pebbles and form a ledge. 
San Jose formation - Continued

Regina member (type section):

46. Shale, silty clay, light-gray. The upper part weathers purplish and contains small limestone nodules. The unit forms a slope. . . . .

45. Shale, red; forms a poorly exposed slope. .

44. Sandstone, buff, fine-to coarse-grained; forms a small ledge. . . . . . . . . .

43. Sandstone, buff, fine - to coarse-grained, arkosic; forms a vertical ledge.......... 20

42. Shale, silty clay, greenish-gray and maroon. . 30

41. Shale, silty clay, greenish-gray with rustybrown mottling; slope-forming. . . . . . .

40. Shale, silty clay, maroon with greenish-gray streaks; slope-forming. . . . . . . .

Llaves member (tongue):

39. Sandstone, light-gray to buff; locally stained red by clay washing down from above. The sandstone is fine - to very coarse grained, and contains many lenses of granules and smallpebble conglornerate. Pebbles and granules are mostly quartzite. Chert fragments and weathered feldspar are common. Highly irregular streamchannel cross bedding. Unit forms a massive vertical ledge. This tongue of the Llaves member persists to the south where it contains thin lenses of shale. . . . . . . . . . . . .

Regina member (type section)- Continued

38. Shale, silty clay, light-gray to olive-green; locally weathers to purplish bands. Unit forms a steep slope. . . . . . . . . . .

37. Shale, silty clay, dull-red. . . . . . .

36. Shale, siltstone, light olive-gray; weathers purplish.

35. Shale, clay, dull-red weathering. . . . .

34. Sandstone, buff, medium-grained ..... .

33. Shale, silty clay, light-gray. . . . . .

32. Shale, clay, light-purple. . . . . . .

31. Shale, clay; weathers light-red....... 30

30. Claystone, gray, mottled brown; forms a light-tan band. To the north the unit grades into a ledge forming sandstone tongue of the Llaves member.. 13 


\section{San Jose formation - Continued}

Regina member (type section) - Continued

29. Shale, argillaceous silt, light-gray. . . . .

28. Sandstone, light yellowish-gray, coarsegrained; forms a soft yellow band, and contains thin bands of lignitic clay . . . . . .

27. Shale, silty clay, gray. . . . . . . .

26. Siltstone, brick-red, forms conspicuous band. .

25. Shale, silty clay, light brownish-gray with a faint purple band near the top. . . . . . .

24. Shale, silty clay, light-gray; contains a few lenses of soft, gray, medium- to coarsegrained sandstone $2-5$ feet thick. . . . . .

23. Sandstone, buff to light yellow-gray; contains very coarse grained to granule-size quartz with feldspar fragments and small clay pebbles. The unit caps a point on the east end of a small ridge and lenses out to the west into gray shale. The unit thickens northward to form a strong ledge. . . . . . . . . . . . .

22. Shale, silty clay, pale-tan, gray, and olive-gray; contains thin bands of soft argillaceous sandstone and siltstone. Unit forms a steep slope on an eastward-projecting spur. . . . . . .

21. Sandstone, buff to white, coarse-grained; locally contains quartzi te pebbles as large as 3 inches in longest dimension. The unit is a channel deposit locally 8-10 feet thick, and forms a hard ledge capping a long low cuesta. . . . . .

20. Shale, silty clay, light-gray to light olive-gray; has two thin bands of purple and red clay, and forms a slope. . . . . . . . . . .

19. Sandstone, light-gray; composed of very coarse grained to granule-size quartzite fragments and some feldspar. The unit is a channel deposit and forms a small ledge. . . . . . . . . . .

18. Shale, silty clay; upper half is olive-gray; lower half is light-gray. Unit forms a slope. . . . 22

Total thickness of main part of Regina member (inclixding tongue of Llaves member, unit 39). . 
San Jose formation - Continued

Cuba Mesa member, upper tongue $\left(\mathrm{Tsc}_{3}\right)$ :

17. Sandstone, light-gray, stained light-yellow;

composed of very coarse grained quartz and quartzite with a trace of feldspar and mica.

Sandstone contains numerous small quartzite

pebbles and forms a small ledge. . . . . . .

16. Shale, silty clay, light-gray with light-red and olive-colored bands; slope-forming . . . . . 27.5

15. Sandstone, buff; weathers light yellowish-brown; medium - to coarse-grained, arkosic. Upper part contains nume rous large cobbles and pebbles of quartzite and schist. Unit forms strong multi- ple ledges stepped back along shale lenses included in the sandstone. This sandstone was traced southward to the locality of measurement of unit 16. . . . . . . . . . . . 30

Regina member, tongue (Tsr):

14. Shale, light greenish-gray and gray; contains 5 or 6 lenses of soft light-gray channel sandstone. Forms a slope and becomes thinner to the north.. 119

13. Sandstone, light-gray to buff; contains interbedded shale............... . 9

12. Shale, silty clay, greenish-gray, slope-forming. 16

Cuba Mesa member, lower tongue ( $\mathrm{Tsc}_{2}$ ):

11. Sandstone, light-gray to buff; weathers yellowbrown; medium - to coarse-grained, feldspathic. Sandstone contains thin stringers of small pebbles and is irregularly bedded. Forms a ledge. . . . 29

10. Shale, silty clay, light olive-gray; contains thin sandy lenses, and weathers to a slope. . . . .

9. Sandstone, light-gray, limonite-stained; mediumto coarse-grained with a few granules. Upper half is brown and contains thin clay lenses. Unit weathers to a slope. . . . . . . . . 
San Jose formation - Continued

Regina member, tongue ( $\mathrm{Ts}$ ):

8. Shale, silty clay, greenish-gray; lower 4 feet weathers dull red. Forms slope. . . . .

Cuba Mesa member, main part ( $\mathrm{Tsc}$ ):

7. Sandstone, brown to yellowtish-brown;

contains fine-grained to granule-size quartz and quartzite and some feldspar and scattered small quartzite pebbles. Concretionary weathering causes brown "cannonballs" up to 2 feet in diameter. Unit forms a strong persistent ledge. . . . . . . . . . . 27

Total thickness of Cuba Mesa member (including . tongues of Regina member). . . . . . . . .

Nacimiento formation (in part):

6. Shale, silty sandy clay, light olive-gray; forms poorly exposed slope. . . . . . . . . .

5. Sandstone, light-tan, fine-to medium-grained, thin-bedded; forms poorly exposed slope. .

4. Shale, silty clay, dark-gray; slightly bentonitic. Upper half is brown lignitic sandy shale. Unit forms a poorly exposed slope. . . . . .

3. Sandstone, light-tan, fine-to medium-grained, soft, poorly exposed. .........

2. Sandstone, dark rusty-brown, medium-to coarsegrained; contains stringers of quartzite granules and small pebbles, and forms a small ledge. .

1. Shale, clay, dark-gray; forms a poorly exposed slope............... 
Locality 4. Section measured on the eastwa A-projecting spur of the ridge southwest of Spring Canyon in the $N 1 / 2 \mathrm{sec} .18, T .25$

N., R. 1 E.

Top

Thickness

San Jose formation:

(feet)

Llaves member (type section of lower part):

50, Sandstone, light reddish-brown. coarse-grained;

weathers to a massive rounded blut cauping top

of narrow part of ridge. . . . . .

49. Sandstone, light yellowish-brown; composed of medium- to very coarse grained, a rkosic, quartz sand containing small cobbles of gray to purplish quartzite. Channel cross bedding. Holds up naxrow ledge. . . . . . . . . . . .

48. Shale, silty clay, gray to olive; weathers red and contains interbedded red-weathering sandstone..

47. Sandstone, buff, coarse-grained with scattered granules and small pebbles; forms small ledge..

46. Shale, silty clay, light-gray to olive; weathers red. Unit contains interbedded thin sandstone..

45. Sandstone, light-brown weathering, coarse - to very coarse grained; contains numerous lenses of pebbles as large as 2 inches ir diameter. Unit forms a strong ledge.

44. Shale, silty clay, red-weathering; contains thin sandstone beds. . . . . . . . . . . . .

43. Sandstone, light pinkish-brown, fine-to coarsegrained; forms a ledge on a long narrow spur.

42. Shale, silty sandy clay, light-gray to light olivegray; contains thin sandstone beds, and forms a slope. . . . . . . . . . . . . .

41. Sandstone, grayish-yellow, very coarse grained; contains numerous scattered pebbles . . .

40. Sandstone, light reddish-gray, fine-grained. Beds are about 6 inches thick and separated by stringers of gray shale. Entire unit weathers red and forms a retreating slope on a small bench. . . . . . 15

39. Sandstone, light yellowish-brown; similar to unit 37. Forms a strong ledge. . . . . . .

38. Shale, clay, red to gray; and interbedded shaly sandstone. Unit forms a notch in cliffs. . . 
Locality 4 - Continued

San Jose formation - Continued

Thickness

(feet)

Llaves member - Continued

37. Sandstone, light yellowish-brown, fine-to coarse-

grained, arkosic; contains a lens of small-pebble

gravel, and fossil wood impressions. Unit is

cross bedded and forms a strong cliff. . . .

36. Sandstone, light reddish-gray to maroon, fine to medium-grained. Sandstone beds are about

1 foot thick, and are separated by red-weathering clay shale beds. Unit forms a slope. To the north this unit grades into hard sandstone. . . . . 33

35. Shale, silty clay, light olive-gray; forms a slope.. 6

34. Sandstone, light-brown, medium-to coarse grained; forms a small ledge. . . . . . . 9

33. Shale, sandy siltstone, greenish-gray, reddishweathe ring. . . . . . . . . . . . .

32. Sandstone, earthy, pale-maroon, fine- to mediumgrained. 50 feet to the south this unit becomes massive, yellow, coarse-grained sandstone.

31. Shale, clay; weathers pale maroon. . . . . . .

30. Sandstone, yellow, coarse-grained; contains granules of quariz and feldspar, and pebbles and cobbles of quartzite. Unit is cross bedded and ledge forming.

29. Shale, silty clay, light-gray to olive-gray; weathers pale maroon, and forms a slope. . . .

28. Sandstone, light purplish-brown and red, fine-to
medium-grained, earthy; forms a rounded,

28. Sandstone, light purplish-brown and red, fine
medium-grained, earthy; forms a rounded, irregular ledge.

27. Sandstone, buff, fine-to coarse-grained; contains
granules and scattered small pebbles. Unit is

27. Sandstone, buff, fine-to coarse-grained; contains
granules and scattered small pebbles. Unit is cross bedded and forms a strong ledge . .
.

26. Shale, argillaceous silt and fine-grained sandstone, To the south this unit is cut out by channel sandstone of the above unit. . . . . . . . .

25. Sandstone, reddish-stained, and interbedded thin reddish shale. Sandstone is fine-to medium-grained and contains a few small pebbles. Sandstone beds are 5-12 feet thick and form retreating ledges separated by notches weathered in shale. Bedding is irregular and the sandstones are channel bedded.

Total thickness of preserved lower part of

Llaves member. 
San Jose formation - Continued

Cuba Mesa member:

24. Sandstone, buff, medium-to coarse-grained, arkosic; contains lenses of pebbles and, near the top, scattered cobbles. Forms a strong cliff.

23. Shale, siltston e, claystone, and very tine grained sandstone, redish-and greenish gra Forms a slope.

22. Sandstone, gray to reddish-purple, medium-to - very coarse grained, arkosic. Contains large pebbles and small cobbles which are mostly quartzite. Some pebbles are feldspar, and volcanic rocks. Channel cross bedded. Forms a massive cliff. . . . . . . . . . . . 39

21. Covered. . . . . . . . . . . . 10

20. Shale, silty clay, dark-gray, slope-forming. . 25

19. Sandstone, gray to light purplish-gray, very coarse grained; contains pebbles and is cross bedded. Forms a rounded ledge. . . . . .

18. Sandstone, olive-gray, fine-to medium-grained, slope-forming. . . . . . . . . . . .

17. Sandstone, buff, arkosic.......... 2

16. Shale, clay, gray. . . . . . . . . . . 4 4

15. Sandstone, olive-green, shaly; forms poorly exposed slope. . . . . . . . . . . . . 7

14. Shale, clay, siltstone; and sandstone, green to pale-purplish. Forms a soft slope. . . .

13. Sandstone, buff to greenish-gray, thin- to shalybedded; forms a soft slope. . . . . . . .

12. Sandstone, buff; forms soft, retreating ledges. .

11. Sandstone, medium-grained; forms a small ledge.

10. Shale, silty, argillaceous, sandy, greenish-gray; forms a slope. . . . . . . . . . .

9. Sandstone, yellowish-gray, fine-to very coarse grained, arkosic; contains pebbles of quartz, quartzite, feldspar, and volcanic rock. Forms a ledge.

8. Sandstone, yellow-gray, fine-to very coarse grained, arkosic; contains lenses of granules and small pebbles. Channel cross bedded. Forms a massive ledge.

Total thickness of Cuba Mesa me mber. 
Nacimiento formation (in part):

7. Sandstone, yellow to buff, fine-grained, argillaceous; forms a notch. . . . . . . 8

6. Shale, siltstone and clay, gray; slope-forming . . 12

5. Sandstone, olive-green, fine-grained, soft; shaly-bedded. . . . . . . . . . . ?

4. Sandstone, similar to unit 2. Base of unit is a small ledge, upper part is a soft slope. . . . 15

3. Shale, sandy clay, olive-green; slope-forming . 18

2. Sandstone, olive-green, fine-grained; forms a small ledge and grades into overlying unit. . . 9

1. Sandstone, yellowish-gray, medium - to very coarse grained; contains lenses of pebbles, and lenses of gray clay shale. Irregular cross bedding. Forms a ledge. . . . . . 40

Locality 5. Section measured on a ridge on the northern side of Canyoncito de las Yeguas east of Pasture Canyon, from the SW 1/4 sec. 4, T. 25 N., R. 1 W. to the center of sec. 33, T. 26 N., R. 1 W.

Top

Thickness (feet)

San Jose formation:

Llaves member (type section of upper part):

Sandstone, buff, gray, brown, and red, fine-to very coarse grained, arkosic, conglomeratic; contains beds of red and gray silty clay shale, but is mostly sandstone. Lowest part of the unit is buff, massive, ledge-forming sandstone containing some shale, and about 120 feet thick. Above this is red shale with thin interbeds of sardstone about 70 feet thick and mapped as a tongue of the Tacipitos member. Above this is brown and red, thin - to thickbedded, ledge-forming sandstone with thin interbeds of red shale. The upper part of the unit contains several thick beds of shaly, soft, red sandstone. . . $450+$

The lower part of the basal sandstone of this unit probably is nearly equivalent to units 49-50 of the Llaves member at locality 4. West of locality 5 near the Continental Divide are more sandstone and shale beds of the Llaves member. These highest beds of the member are estimated to be about 150 feet thick. 
Locality 6. Stratigraphic section modifjed slightly $f_{\text {, m ine }}$ section measured by Simpson (1948, p. 370-371) near the head of north branch of Oso Canyon. Figure 3 of Simpson (1946) shows this section (no. 1) measured east of the Wayne Hatley ranch. The locality appears to be in sec. $30, \mathrm{~T} .25 \mathrm{~N} ., \mathrm{R}, 1 \mathrm{~W}$. The rocks were considered to be characteristic of the "Largo facies" by Simpson.

Top

San Jose formation:

Tapicitos member, lower part (typical exposures):

13. Sandstone, buff, massive in appearance but cross bedded, hard, bench-forming. Top eroded. On an adjacent peak about 50 feet more of similar beds are present. These highest beds probably are nearly equivalent to the tongue of the Llaves member near the middle of the Tapicitos member along State Highway 95 in sec. 2, T. 25 N., R. $2 \mathrm{~W}$.

12. Clay, banded, red. . . . . . . . . . 15

11. Sandstone, like unit 13. . . . . . . . . 15

10. Clay and sandy clay, bright-red, in regularly alte rnating beds. . . . . . . . . . 40

9. Sandstone, local lens wedging out in a few feet laterally. . . . . . . . . . . . 2

8. Clay, red, massive but slightly banded. . . . . 15

7. Sandstone, soft; wedges out laterally. . . . . 5

6. Clay, red, banded, with buff sandstone lenses in the upper part. . . . . . . . . . . 80

5. Sandstone, light-gray, hard, cross-bedded; persistent. . . . . . . . . . . .

4. Clay, red, banded; bluish-or greenish-gray spots and lenses. Reddish siltstone and very fine grained sandstone interbedded. American Museum of Natural History fossil mammal quarry, locality 150 , is 13.5 feet above base of this unit. . .

3. Sandstone, white; soft except for occasional plates weathe ring hard and brown. . . . . . . .

2. Clay, variegated; mottled purplish and yellow . . 12

1. Clay, red. . . . . . . . . . . . .

Total thickness of Tapicitos member preserved at this locality. . . . . . . . .

Base of hill; lower beds covered by slopewash. Unit 1 is about 25-50 feet above the base of the Tapicitos member and the top of the persistent medial sandstone of the Llaves member. 
Anderson, R. Y., 1960, Cretaceous-Tertiary palynology, eastern side of the San Juan Basin, New Mexico: New Mexico Bur. Mines and Min. Res. Mem. 6, 58 p.

Armstrong, A. K., 1955, Preliminary observations on the Mississippian system of northern New Mexico: New Mexico Bur. Mines and Min. Res. Circ. 39, 42 p.

Atwood, W. W., and Mather, K. F., 1932, Physiography and Quaternary geology of the San Juan Mountains, Colorado: U.S. Geol. Survey Prof. Paper 166, 176 p.

Baltz, E. H., Jr., 1953, Stratigraphic relationships of Cretaceous and early Tertiary rocks of a part of northwestern San Juan Basin: Univ. New Mexico unpub. master's thesis, 101 p. ; also U. S. Geol. Survey open-file rept.

Baltz, E. H., Jr., and Bachman, G. O., 1956, Notes on the geology of the southeastern Sangre de Cristo Mountains, New Mexico, in Guidebook of southeastern Sangre de Cristo Mountains, New Mexico: New Mexico Geol. Soc. 7th Field Conf., 1956; p. 96-108.

Barnes, Harley, 1953, Geology of the Ignacio area, Ignacio and Pagosa Springs quadrangles, La Plata and Archuleta Counties, Colorado: U. S. Geol. Survey Oil and Gas Inv. Map OM-138.

Barnes, Harley, Baltz, E. H., Jr., and Hayes, P. T., 1954, Geology and fuel resources of the Red Mesa area, La Plata and Montezuma Counties, Colorado: U. S. Geol. Survey Oil and Gas Inv. Map OM-149.

Bauer, C. M., 1916, Stratigraphy of a part of the Chaco River Valley: U. S. Geol. Survey Prof. Paper 98, p. 271-278.

Bauer, C. M., and Reeside, J. B., Jr., 1921, Coal in the middle and eastern parts of San Juan County, New Mexico: U. S. Geol. Survey Bull. 716-G, p. 155-237.

Beaumont, E. C., Dane, C. H., and Sears, J. D., 1956, Revised nomenclature of Mesaverde group in San Juan Basin, New Mexico: Am. Assoc. Petroleum Geologists Bull., v. 40, p. 2149-2162. 
Brown, Barnum, 1910. The Crelaceous Ojo Alam bed of New Mexico, with description of the new dinosaur genus Kritosaurus: Am. Mus. Nat. History Bull., v. 28, p. 267-274.

Bryan, Kirk, and McCann, F. T., 1936, Successive pediments and terraces of the upper Rio Puerco in New Mexico: Jour. Geology, v. 44 , no. 2 pt. 1 , p. $145-172$.

Budding, A. J., Pitrat, C. W., and Smith, C. T., 1960, Geology of the outheastern part of the Chama basin, in Guidebrok of Rio Chama country: New Mexico Geol. Soc. 11 th Field Conf., 1960; p. 78.92.

Burbank, W. S., and Goddard, E. N., 1937, Thr sting in Hue lano Park Colorado, and related problems of orogeny in the S $\mathrm{S} g \mathrm{re}$ de $\mathrm{C}$. st Mountains: Geol. Soc. America Bull., v. 48, p. 9s1-976.

Church, F. S., and Hack, J. T., 1939, An exhumed e rosion surface in the Jemez Mountains, New Mexico: Jour. Geology, v. 47, p. $613-629$.

Collier, A. J., 1919. Coal south of Mancos, Montezuma County, Colorado: U. S. Geol. Survey Bull. 691, p. 293-310.

Cope, E. D., 1875, Report on the geology of that part of northwestern New Mexico examined during the field season of 1874: Ann. Rept. Geog. Explor. West of the 100th Mer. [Wheeler Survey], appendix LL, Ann. Rept. Chief of Engineers for 1875, p. 981-1017.

1877, Report. upon the extinct vertebrates obtained in New Mexico by parties of the expedition of 1874: Geog. Survey West of 100th Mer. [Wheeler Survey], pt. 2, p. 1-370.

1881, On some mammalia of the lowest Eocene beds of New Mexico: Am. Philos. Soc. Proc., v. 19, p. 484-495.

Cross, C. W., and Larsen, E. S., 1935, A brief review of the geology of the San Juan region of southwestern Colorado: U. S. Geol. Survey Bull. $843,138 \mathrm{p}$.

Cross, C. W., Spencer, A. C., and Purington, C. W., 1899, Description of the La Plata quadrangle [Colorado]: U. S. Geol. Survey Geol. Atlas, Folio 60,14 p. [Publ. 1901].

Dallmus, K. F., 1958, Mechanics of basin evolution and its relation to the habitat of oil in the basin, in Habitat of oil: Am. Assoc. Petroleum Geologists, Tulsa, p. 883-931. 
Dane, C. H., 1932, Notes on the Puerco and Torrejon Lorniations, San Juan Basin, New Mexico: Washington Acad. Sci. Jour., v. 22, p. $406-411$.

...... 1936, The La Ventana-Chacra Mesa coal field, pt. 3 in Geology and fuel resources of the southern part of the San Juan Basin, New Mexico: U. S. Geol. Survey Bull. 860-C, p. 81-161.

1946, Stratigraphic relations of Eocene, Paleocene, and latest Cretaceous formations of eastern side of San Juan Basin, New Mexico: U. S. Geol. Survey Oil and Gas Inv. Prelim. Chart 24.

1948, Geologic map of part of eastern San Juan Basin, Rio A r riba County, New Mexica: U. S. Geol. Survey Oil and Gas Inv. Prelim. Map 78.

1960a, The boundary between rocks of Carlile and Niobrara age in San Juan Basin, New Mexico and Colorado: Am. Jour. Sci., Bradley Vol., v. 258A, p. 46-56.

1960b, The Dakota sandstone and Mancos shale of the eastern side of San Juan Basir. New Mexico, in Guidebook of Rio Chama country: New Mexico Geol. Soc. 11th Field Conf., 1960; p. 63-74.

Dane, C. H., and Bachman, G. O., 1957, Preliminary geologic map of the northwestern part of New Mexico: U. S. Geol. Survey Misc. Geol. Inv. Map I-224.

De Sitter, L. U., 1956, Structural geology: New York, McGraw-Hill, 552 p.

Dilworth, O. L., 1960, Upper Cretaceous Farmington sandstone of northeastern Sar Juan County, New Mexico: Univ. New Mexico unpub. master's thesis, $96 \mathrm{p}$.

Fenneman, N. M., and Johnson, D. W., 1946, Map of physical divisions of the United States: Prepared in cooperation with the Physiographic Committee, U. S. Geol. Survey.

Fitter, F. L., 1958, Stratigraphy and structure of the French Mesa area, Rio Arriba County, New Mexico: Univ. New Mexico unpub. master's thesis, $66 \mathrm{p}$.

Fitzsimmons, J. P., Armstrong, A. K., and Gordon, Mackenzie, Jr., 1956, Arroyo Penasco formation, Mississippian, north-central New Mexico: Am. Assoc. Petroleum Geologists Bull., v. 40, p. 1935-1944. 
Gardner, J. H., 1909, The coal field between Gallina and Raton Springs, New Mexico, in the San Juan coal region, in Contributions to economic geology, 1907, pt. 2--Coal and lignite: U. S. Geol. Survey Bull. 341, p. 335-351.

1910, The Puerco and Torrejon formations of the Nacimiento group: Jour. Geology, v. 18, p. 702-741.

Gilmore, C. W.., 1916, Vertebrate faunas of the Ojo Alamo, Kirtland, and Fruitland formations: U. S. Geol. Survey Prof. Paper 98, p. 279-308.

1919, Reptilian faunas of the Torrejon, Puerco, and underlying Upper Cretaceous formations of San Juan County, New Mexico: U. S. Geol. Survey Prof. Paper 119, 71 p.

...... 1922, A new sauropod dinosaur from the Ojo Alamo formation of New Mexico: Smithsonian Misc. Coll., v. 72, no. 14.

Granger, Walter, 1914, On the names of lower Eocene faunal horizons of Wyoming and New Mexico: Am. Mus. Nat. History Bull., v. 33, p. $201-207$.

..... 1917, Notes on Paleocene and lower Eocene mammal horizons of northern New Mexico and southern Colorado: Am. Mus. Nat. History Bull., v. 37, p. 821-830.

Hantzschel, Walter, 1939, Tidal flat deposits (Wattenschlick), in Recent marine sediments, a symposium; P. D. Trask, editor: $\overline{A m}$. Assoc. Petroleum Geologists, p. 195-206.

Hayes, P. T., and Zapp, A. D., 1955, Geology and fuel resources of the Uppe Cretaceous rocks of the Barker dome-Fruitland area, San Juan County, New Mexico: U. S. Geol. Survey Oil and Gas Inv. Map OM-144, 2 sheets.

Holmes, W. H., 1877, Geological report on the San Juan district: U. S. Geol. and Geog. Survey Terr. [Hayden Survey] Ann. Rept. for 1875, p. $237-276$.

Hutson, O C., 1958, Geology of the northern end of San Pedro Mountain, Rio Arriba and Sandoval Counties, New Mexico: Univ. New Mexico unpub. master's thesis, $55 \mathrm{p}$.

Johnson, R. B., Dixon, G. H., and Wanek, A. A., 1956, Late Cretaceous and Tertiary stratigraphy of the Raton basin of New Mexico and colorado, in Guidebook of southeastern Sangre de Cristo Mountains, New Mexico: New Mexico Geol. Soc. 7th Field Conf., 1956; p. 122-133. 
Johnson, R. B., and Wood, G. H., Jr., 1956, Stratigraphy of Upper Cretaceous and Tertiary rocks of Raton Basin, Colorado and New Mexico: Am. Assoc. Petroleum Geologists Bull., v. 40, p. $707-721$.

Just, Evan, 1937, Geology and economic features of the pegmatities of Taos and Rio Arriba Counties, New Mexico: New Mexico Bur. Mines and Min. Res. Bull. 13, 73 p.

Kelley, V. C., 1950, Regional structure of the San Juan Basin, in Guidebook of the San Juan Basin, New Mexico and Colorado: New Mexico Geol. Soc. 1st Field Conf., 1950; p. 101-108.

1951, Tectonics of the San Juan Basin, in Guidebook of the south and west sides of the San Juan Basin, New Mexico and Arizona: New Mexico Geol. Soc. 2d Field Conf., 1951; p. 124-131.

1955, Regional tectonics of the Colorado Plateau and relationship to the origin and distribution of uranium: Univ. New Mexico Pub. in Geol. , no. 5, 120 p.

1957a, General geology and tectonics of the western San Juan Mountains, Colorado, in Guidebook of the southwestern San Juan Mountains, Colorado: New Mexico Geol. Soc. 8th Field Conf., 1957 ; p. $154-162$.

1957b, Tectonics of the San Juan Basin and surrounding areas, in Geology of southwestern San Juan Basin: Four Corners Geol. Soc. 2d Field Conf., 1957; p. 44-52.

Kelley, V. C., and Clinton, N. J., 1960, Fracture systems and tectonic elements of the Colorado Plateau: Univ. New Mexico Pub. in Geol., no. $6,104 \mathrm{p}$.

Kelley, V. C., and Silver, Caswell, 1952, Geology of the Caballo Mountains-with special reference to regional stratigraphy and structure and to mineral resources including oil and gas: Univ. New Mexico Pub. in Geol., no. 4, 286 p.

Knowlton, F. H., 1916, Flora of the Fruitland and Kirtland formations: U. S. Geol. Survey Prof. Paper 98, p. 327-353.

Larsen, E. S., and Cross, C. W., 1956, Geology and petrology of the San Juan region, southwestern Colorado: U. S. Geol. Survey Prof. Paper 258, 303 p. 
Lookingbill, J. L., 1953, Stratigraphy and structure of the Gallina uplift, Rio Arriba County, New Mexico: Univ. New Mexico unpub, master's thesis, $118 \mathrm{p}$.

Matthew, W. D., 1897, A revision of the Puerco fauna: Am. Mus. Nat. History Bull., v. 9, p. 259-323.

1...... 1914, Evidence of the Paleocene vertebrate fauna on the Cretaceous-Tertiary problem: Geol. Soc. America Bull., v. 25 , p. $381-402$.

....... 1921, Fossil vertebrates and the Cretaceous-Tertiary problem: Am. Jour. Sci., 5th ser., v. 2, p. 209-227.

....... 1937, Paleocene faunas of the San Juan Basin, New Mexico: Am. Philos. Soc. Trans., n. s., v. 30, 510 p.

Matthew, W. D., and Granger, Walter, 1921, New genera of Paleocene mammals: Am. Mus. Novitates, no. 13, 7 p.

Muehlberger, W. R., 1960, Structure of the central Chama platform, northern Rio Arriba County, New Mexico, in Guidebook of Rio Chama country: New Mexico Geol. Soc. 11 th Field Conf., 1960; p. 103-109.

Muehlberger, W. R., Adams, G. E., Longood, T. E., Jr., and St. John, B. E., 1960, Stratigraphy of the Chama quadrangle, northern Rio Arriba County, New Mexico, in Guidebook of Rio Chama country: New Mexico Geol. Soc. 11th Field Conf., 1960; p. 93-102.

New Mexico State Engineer, 1956, Climatological summary, New Mexico, precipitation 1849-1954: New Mexico State Engineer Tech. Rept. 6,407 p.

Northrop, S. A., 1950, General geology of northern New Mexico, in Guidebook for the 4th Field Conf. of the Society of Vertebrate Paleontologists in northern New Mexico: Am. Mus. Nat. History and Univ. New Mexico; p. 26-46.

Pike, W. S., Jr., 1947, Intertonguing marine and nonmarine Upper Cretaceous deposits of New Mexico, Arizona, and southwestern Colorado: Geol. Soc. America Mem. 24, 103 p.

Read, C. B., and Wood, G. H., Jr., 1947, Distribution and correlation of Pennsylvanian rocks in late Paleozoic sedimentary basins of northern New Mexico: Jour. Geology, v. 55, p. 220-236. 
Read, C. B., Wood, G. H., Wanek, A. A., and Machee, P. V., 1949, Stratigraphy and geologic structure in the Piedra River Canyon, Archuleta County, Colorado: U. S. Geol. Survey Oil and Gas Inv. Prelim. Map. 96.

Reeside, J. B., Jr., 1924, Upper Cretaceous and Tertiary formations of the western part of the San Juan Basin, Colorado and New Mexico: U. S. Geol. Survey Prof. Paper 134, p. 1-70.

Renick, B. C., 1931, Geology and ground-water resources of western Sandoval County, New Mexico: U. S. Geol. Survey Water-Supply Paper 620, $117 \mathrm{p}$.

Silver, Caswell, 1950, The occurrence of gas in the Cretaceous rocks of the San Juan Basin, New Mexico and Colorado, in Guidebook of the San Juan Basin, New Mexico and Colorado: New Mexico Geol. Soc. 1st Field Conf., 1950; p. 109-123.

1951, Cretaceous stratigraphy of the San Juan Basin, in Guidebook of the south and west sides of the San Juan Basin, New Mexico and Arizona: New Mexico Geol. Soc. 2d Field Conf., 1951; p. $104-118$.

Simpson, G. G., 1935a, The Tiffany fauna, upper Paleocene. 1. -Multituberculata, Marsupialia, Insectivora, and ? Chiroptera: Am. Mus. Novitates, no. 795,19 p.

....... 1935b, The Tiffany fauna, upper Paleocene. 2. -Structure and relationships of Plesiadapis: Am. Mus. Novitates, no. 816, 30 p.

1935c, The Tiffany fauna, upper Pairocene. 3. - Primates, Carnivora, Condylarthra, and Amblypoda: Am. Mus. Novitates, no. 817,28 p.

1948, The Eocene of the San Juan Basin, New Mexico: Am. Jour. Sci., v. 246, pt. 1, p. 257-282; pt. 2, p. 363-385.

1959, Fossil mammals from the type area of the Puerco and Nacimiento strata, Paleocene of New Mexico: Am. Mus. Novitates no. $1957,22 \mathrm{p}$.

Sinclair, W. J., and Granger, Walter, 1914, Paleocene deposits of the San Juan Basin, New Mexico: Am. Mus. Nat. History Bull. , v. 33 , p. $297-316$.

Smith, C. T., and Muehlberger, W. R., 1960, Geologic map of the Ri Chama country, in Guidebook of Rio Chama country: New Mexico Geol. Soc. 11 th Field Conf., 1960. 
Smith, H. T. U., 1938, Tertiary geology of the Ab qusu quadrangle, New Mexico: Jour. Geology, v. 46, p. 933-965.

Stanton, T. W., 1916, Nonmarine Cretaceous invertebrates.of the San Juan Basin: U. S. Geol. Survey Prof. Paper 98, p. 309-326.

Stearns, C. E., 1943, The Galisteo formation of north-central New Mexico: Jour. Geology, v. 51, p. 301-319.

Van Houten, F. B., 1945, Review of latest Paleocene and early Eocene mammalian faunas: Jour. Paleontology, v. 19, p. 421-461.

1957, Appraisal of Ridgeway and Gunnison "tillitges", southwestern Colorado: Geol. Soc. America Bull., v. 68, p. 383-388.

Wanek, A. A., 1954, Geologic map of the Mesa Verde area, Montezuma County, Colorado: U. S. Geol. Survey Oil and Gas Inv. Map OM-152.

Wanek, A. A., and Read, C. B., 1956, Resume of geology, Taos to Eagle Nest and Elizabeth town, in Guidebook of southeastern Sangre de Cristo Mountains, New Mexico: New Mexico Geol. Soc. 7th Field Conf., 1956; p. $82-87$.

Wood, G. H., Jr., and Northrop, S. A., 1946, Geology of the Nacimiento Mountains, San Pedro Mountain, and adjacent plateaus in parts of Sandoval and Rio Arriba Counties, New Mexico: U. S. Geol. Survey Oil and Gas Inv. Prelim. Map 57.

Wood, G. H., Jr., Kelley, V. C., and MacAlpin, A. J., 1948, Geology of the southern part of Archuleta County, Colorado: U. S. Geol. Survey Oil and Gas Inv. Prelim. Map. 81.

Wood, H. E., 2nd, Chaney, R. W., Clark, J., Colbert, E. H., Jepsen, G. L., Reeside, J. B., Jr., and Stock, C., 1941, Nomenclature and correlation of the North American continental Tertiary: Geol. Soc. America Bull., v. 52, p. 1-48.

Zapp, A. D., 1949, Geology and coal resources of the Durango area, La Plata and Montezuma Counties, Colorado: U. S. Geol. Survey Oil and Gas Inv. Prelim. Map 109, 2 sheets. 